WSRC-STI-2006-00109

Revision 0

\title{
SLUDGE BATCH 4 SIMULANT FLOWSHEET STUDIES: PHASE II RESULTS
}

M. E. Stone

D. R. Best

September 2006

Process Science and Engineering Section

Savannah River National Laboratory

Aiken, SC 29808

Prepared for the U.S. Department of Energy Under Contract Number DEAC09-96SR18500

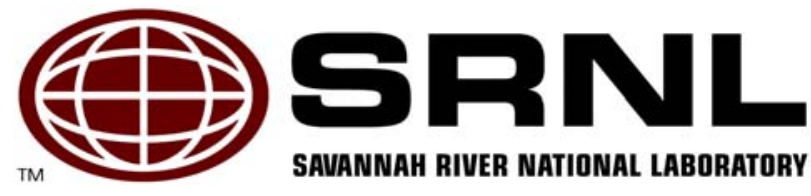


WSRC-STI-2006-00109

Revision 0

\title{
DISCLAIMER
}

This report was prepared by Washington Savannah River Company (WSRC) for the United States Department of Energy under Contract No. DE-AC0996SR18500 and is an account of work performed under that contract. Neither the United States Department of Energy, nor WSRC, nor any of their employees makes any warranty, expressed or implied, or assumes any legal liability or responsibility for the accuracy, completeness, or usefulness, of any information, apparatus, or product or process disclosed herein or represents that its use will not infringe privately owned rights. Reference herein to any specific commercial product, process, or service by trademark, name, manufacturer, or otherwise does not necessarily constitute or imply endorsement, recommendation, or favoring of same by WSRC or by the United States Government or any agency thereof. The views and opinions of the authors expressed herein do not necessarily state or reflect those of the United States Government or any agency thereof.

\author{
Printed in the United States of America \\ Prepared For \\ U.S. Department of Energy
}


WSRC-STI-2006-00109

Revision 0

Key Words: DWPF, Sludge, SB4

Retention: Permanent

\section{SLUDGE BATCH 4 SIMULANT FLOWSHEET STUDIES: PHASE II RESULTS}

M. E. Stone

D. R. Best

September 2006

Process Science and Engineering Savannah River National Laboratory Aiken, SC 29808

Prepared for the U.S. Department of Energy Under Contract Numb DEAC09-96SR18500 


\section{REVIEWS AND APPROVALS}

\section{AUTHORS:}

M. E. Stone, Process Engineering Technology

Date

D. R. Best, Process Engineering Technology

Date

\section{TECHNICAL REVIEWER:}

D. P. Lambert, Process Chemistry Science

Date

\section{APPROVERS:}

\begin{tabular}{ll}
\hline C. C. Herman, Manager, Process Engineering Technology & Date
\end{tabular}

R. E. Edwards, Manager, Process Science and Engineering

Date

J. E. Occhipinti, Manager,

Date

Process Cognizant Engineering - Waste Solidification Engineering 


\section{EXECUTIVE SUMMARY}

The Defense Waste Processing Facility (DWPF) will transition from Sludge Batch 3 (SB3) processing to Sludge Batch 4 (SB4) processing in early fiscal year 2007. Tests were conducted using non-radioactive simulants of the expected SB4 composition to determine the impact of varying the acid stoichiometry during the Sludge Receipt and Adjustment Tank (SRAT) process. The work was conducted to meet the Technical Task Request (TTR) HLW/DWPF/TTR-20040031 and followed the guidelines of a Task Technical and Quality Assurance Plan (TT\&QAP).

The flowsheet studies are performed to evaluate the potential chemical processing issues, hydrogen generation rates, and process slurry rheological properties as a function of acid stoichiometry. Initial SB4 flowsheet studies were conducted to guide decisions during the sludge batch preparation process. These studies were conducted with the estimated SB4 composition at the time of the study. The composition has changed slightly since these studies were completed due to changes in the sludges blended to prepare SB4 and the estimated SB3 heel mass. The SB4 simulant used in this testing was based on Case 15C Blend 1.

No significant processing issues with processing SB4 were noted during the run.

Hydrogen and nitrous oxide generation rates as a function of acid stoichiometry

Hydrogen generation was significantly impacted by the changes in acid stoichiometry from $130 \%$ to $170 \%$ (1.39 to 1.82 mole acid per liter of sludge), but all generation rates were within process limits.

Acid quantities and processing times required for mercury removal

Mercury was added to the sludge simulant at the start of the SRAT cycle as mercuric oxide at 1.0 wt $\%$ (solids basis) based on the expected composition of the SB4 blend. Acid quantities from $130 \%$ to $170 \%$ resulted in satisfactory mercury removal with 12 hours of reflux boiling. Mercury accumulation was noted on the agitator shaft and impellers during the $130 \%$ acid run. This material would not be transferred to the SME cycle, therefore it does not represent failure to remove mercury. However, accumulation of deposits on processing equipment is not desirable and discussions concerning whether or not the accumulation on the impellers would continue or the mercury would slough off during subsequent processing would be highly speculative.

\section{Acid quantities and processing times required for nitrite destruction}

Acid quantities from $130 \%$ to $170 \%$ resulted in satisfactory nitrite destruction with 12 hours of reflux boiling. $130 \%$ probably represents the lower end of the window since there was still a small amount of nitrite present but was less than $1000 \mathrm{mg} / \mathrm{kg}$.

Impact of SB4 composition (in particular, manganese, nickel, mercury, and aluminum) on DWPF processing (i.e. acid addition strategy, foaming, hydrogen generation, REDOX control, rheology, etc.)

Acid quantities from $130 \%$ to $170 \%$ resulted in satisfactory process performance with no significant issues noted. Foaming was noted during formic acid addition, but lab-scale operations did not utilize an antifoam addition between the nitric and formic acid additions. Addition of 
antifoam equal to the amount added at DWPF between the acid additions was sufficient to control foaming. Increased solubility of $\mathrm{Mn}$ and $\mathrm{Ni}$ were noted as acid stoichiometry increased.

Except for the $150 \%$ run, all SRAT products were outside the process limits for yield stress with the lowest acid (130\%) being above the process limit and the $160 \%$ and $170 \%$ runs being below the process limit. The process limits for SME product yield stress were met for the $150 \%$ acid run at $47 \%$ solids, but the $130 \%$ acid run was above process limits and the $160 \%$ and $170 \%$ runs were slightly below process limits. The $150 \%$ acid run exceeded the upper limit for SME product yield stress when concentrated to $50 \mathrm{wt} \%$ solids. It should be noted that the trend seen in rheological properties of the simulants are expected to be similar for the DWPF process slurries, but the absolute values for the simulants are not expected to be prototypical in yield stress or consistency. Adjustment in the solids concentration targets and/or acid stoichiometry should be made if processing problems due to viscous process slurries are noted in DWPF.

The $\mathrm{pH}$ of the condensate generated was typically acidic, but the $130 \%$ acid run resulted in condensate that was basic before the end of the SRAT cycle and throughout the SME cycle with a $\mathrm{pH}$ of approximately 9. All condensates from all other runs had a $\mathrm{pH}$ of less than 4 .

Measured REDOX values for all runs were significantly below the predicted values. REDOX values increased slightly as acid stoichiometry was increased. The issues with REDOX using SB4 simulants have been evaluated in a separate study and will be documented in a separate report.

The following preliminary recommendations apply for DWPF SB4 processing:

An acid stoichiometry of $150 \%$ is recommended for initial SB4 processing with a corresponding acid window of $130 \%$ to $170 \%$. The SB4 simulant used during the testing had a stoichiometric acid requirement of $1.07 \mathrm{~mol} / \mathrm{L}$, giving an acid addition of 1.60 $\mathrm{mol} / \mathrm{L}$ at $150 \%$ acid.

$>$ The manganese term in the electron equivalence REDOX model should be changed from a coefficient of " 2 " to a coefficient of " 5 " for SB4 processing. This recommendation and basis will be documented in a separate report.

No changes to the antifoam addition strategy, acid addition rate, reflux time, or SME solids targets are recommended.

The recommendation for acid addition during the Shielded Cells processing studies will be finalized once the acid inputs are determined. Final recommendations to DWPF on SB4 processing will be made after the Shielded Cells testing and will be based on the results of this study and the Shielded Cells test. 


\section{TABLE OF CONTENTS}

EXECUTIVE SUMMARY ..........................................................................................................

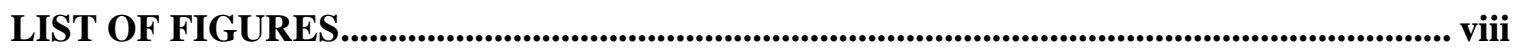

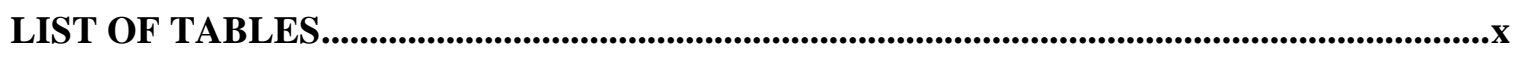

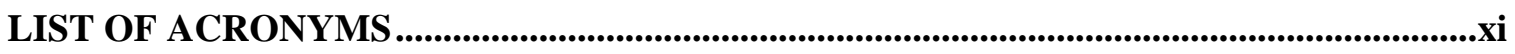

1.0 Introduction and Background......................................................................................................1

2.0 Approach ..........................................................................................................................................................2

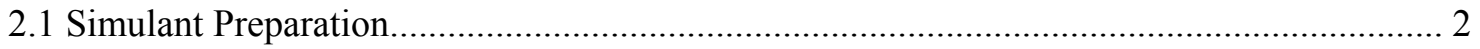

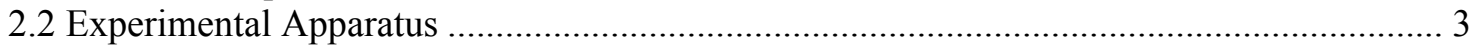

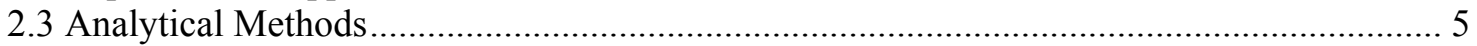

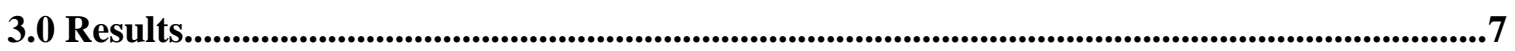

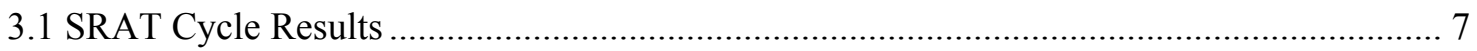

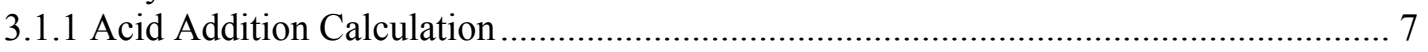

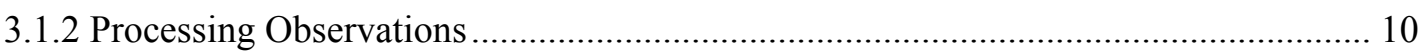

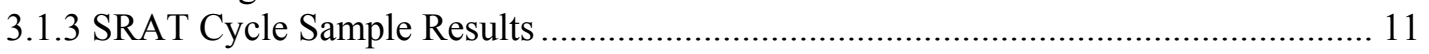

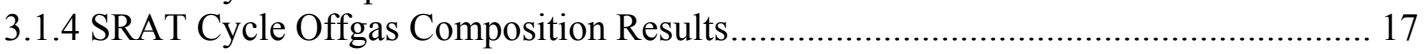

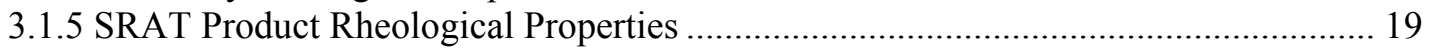

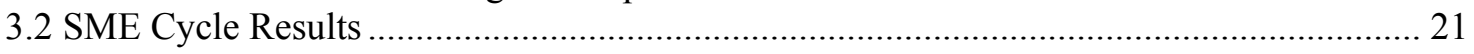

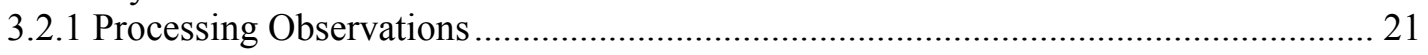

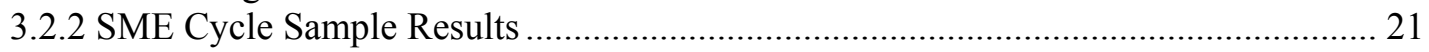

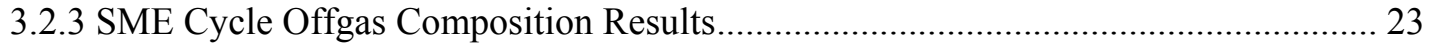

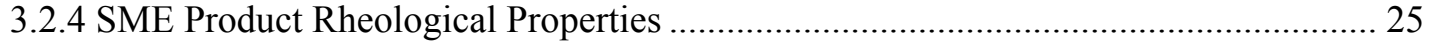

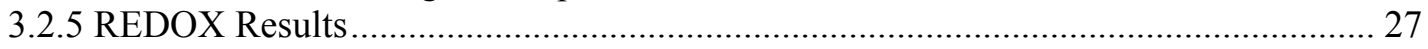

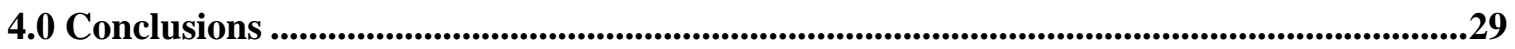

5.0 Recommendations ..................................................................................................................31

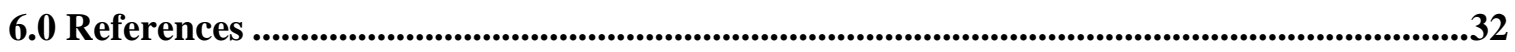

7.0 Acknowledgements ..................................................................................................................34

Appendix A. Sample and Run Results: Tabulated Presentations........................................35

Appendix B. Sample/Run Results: Graphical Presentations......................................................46

Appendix C. Offgas Composition Data .................................................................................74

Appendix D. Rheological Results Charts and Flow Curves ......................................................79 


\section{LIST OF FIGURES}

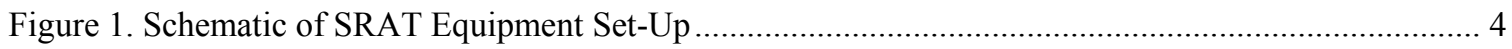

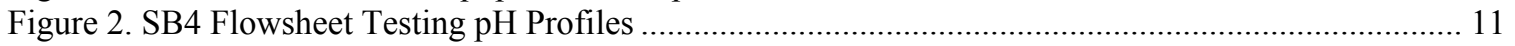

Figure 3. Nitrite Concentration Profile ................................................................................................ 12

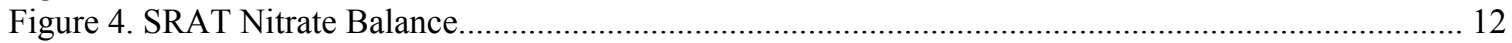

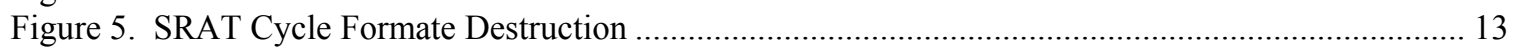

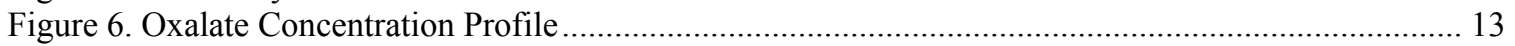

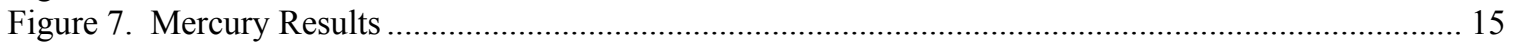

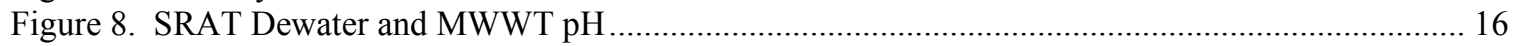

Figure 9. Offgas Data from SB4-62 (150\% Acid Stoichiometry) ……..................................................... 17

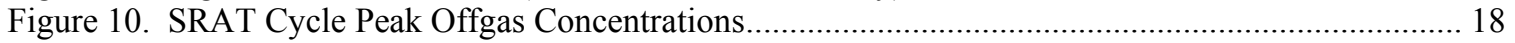

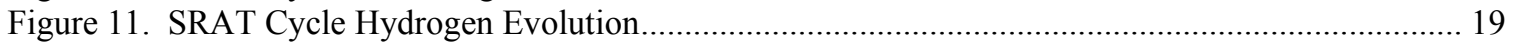

Figure 12. Impact of Acid Stoichiometry on SRAT Product Yield Stress ................................................ 21

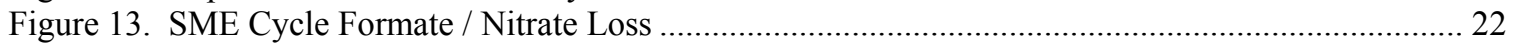

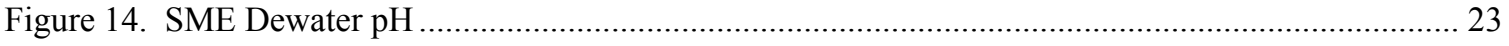

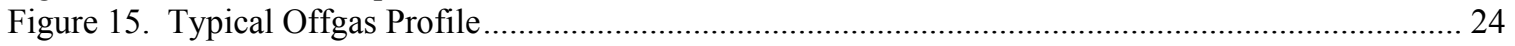

Figure 16. Peak Hydrogen Generation during SME Cycle ........................................................................ 24

Figure 17. SME Cycle Carbon Dioxide Peak Generation Rates............................................................... 25

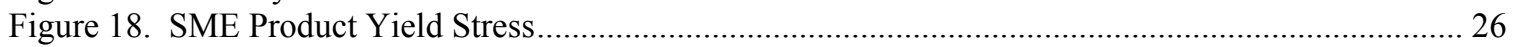

Figure 19. 150\% Acid Rheological Properties versus Solids Content...................................................... 27

Figure 20. SB4 Flowsheet Testing REDOX Results ........................................................................... 28

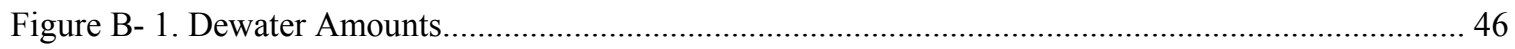

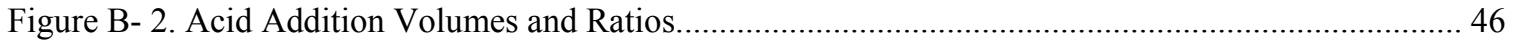

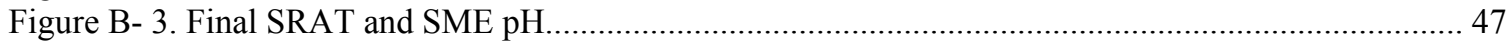

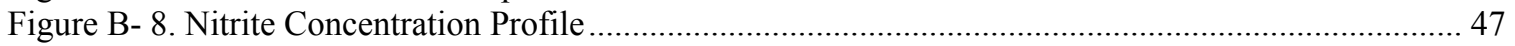

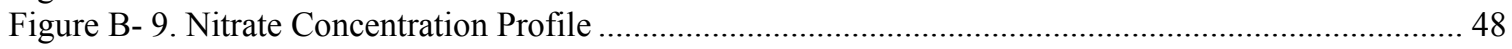

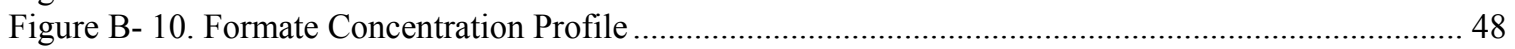

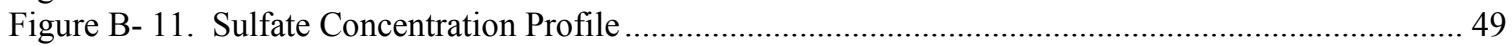

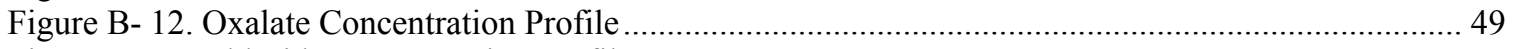

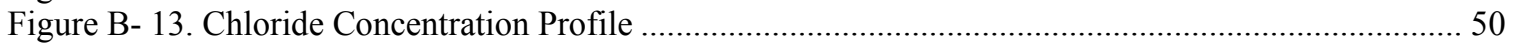

Figure B- 14. Nitrate and Formate Concentration versus Acid Stoichiometry ……..................................... 50

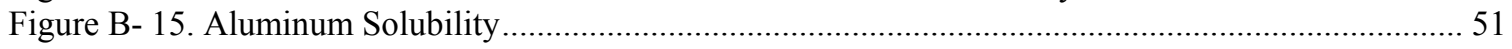

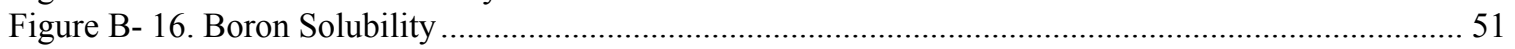

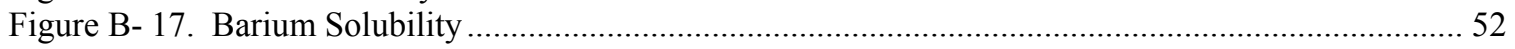

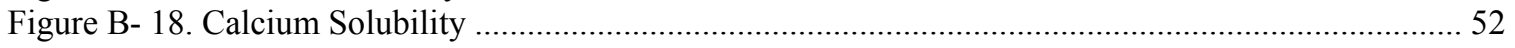

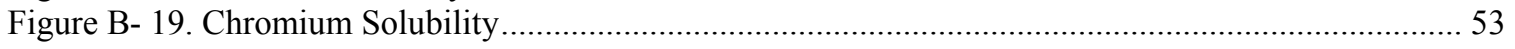

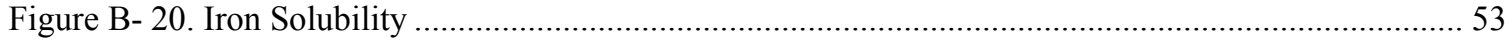

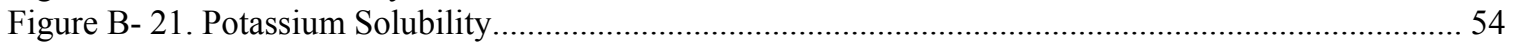

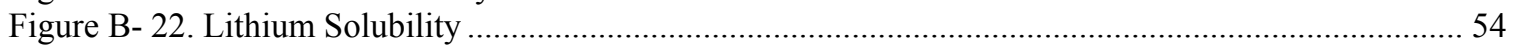

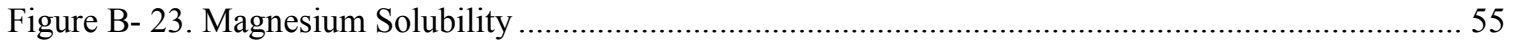

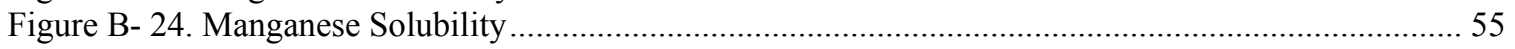

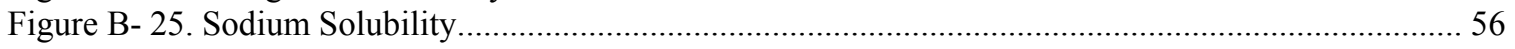

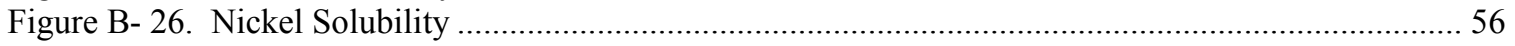

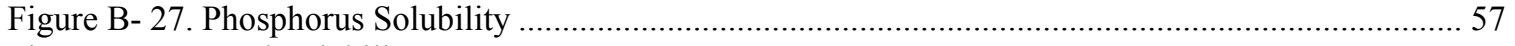

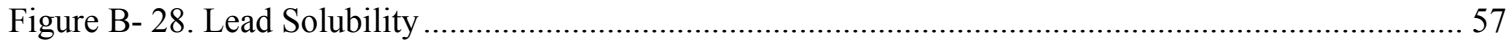

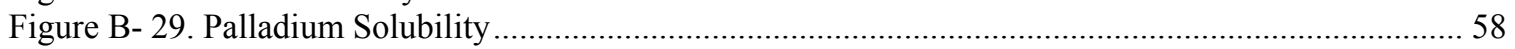

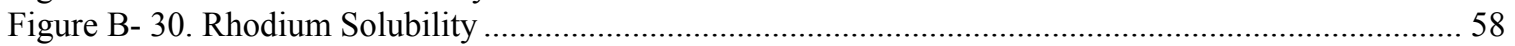

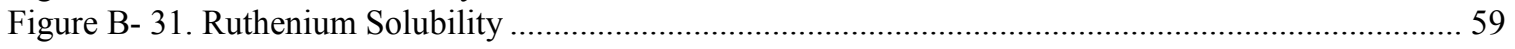

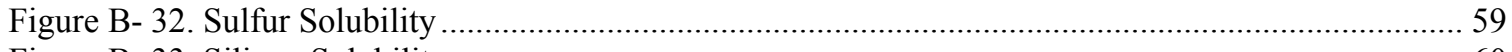

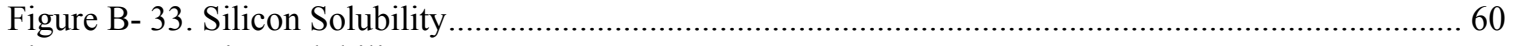

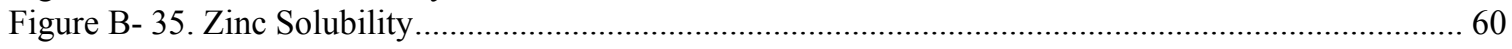

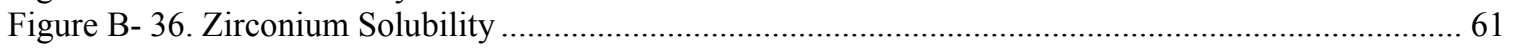


WSRC-STI-2006-00109

Revision 0

Figure B- 37. SRAT Product Soluble Species: High Concentrations......................................................... 61

Figure B- 38. SRAT Product Soluble Species: Medium Concentrations .................................................... 62

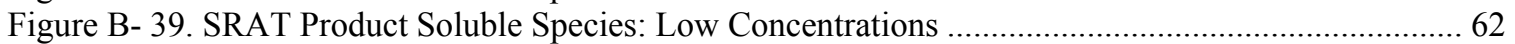

Figure B- 40. SRAT Product Soluble Species: Very Low Concentrations.................................................... 63

Figure B- 41. SME Product Nitrate and Formate versus Acid Stoichiometry ............................................. 63

Figure B- 42. SME Product Soluble Species: Very High Concentrations ........................................................ 64

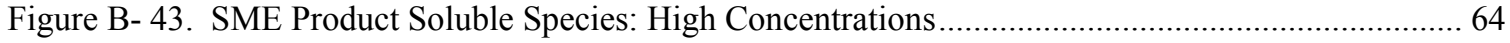

Figure B- 44. SME Product Soluble Species: Medium Concentrations ………............................................ 65

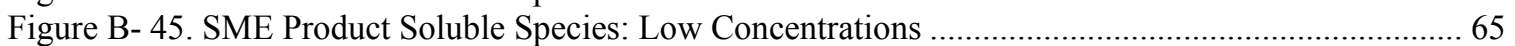

Figure B- 46. SME Product Soluble Species: Very Low Concentrations..................................................... 66

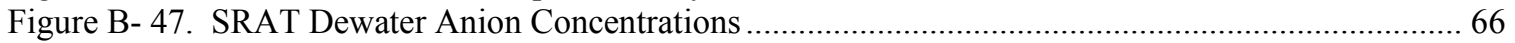

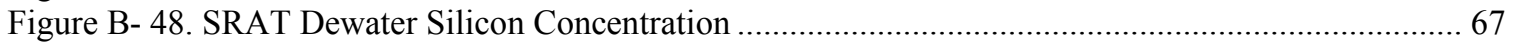

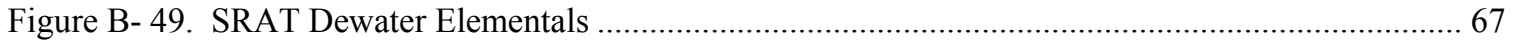

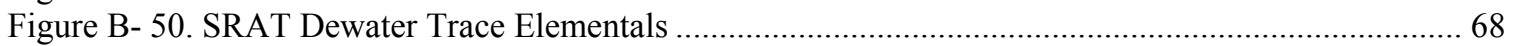

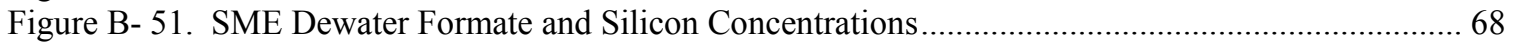

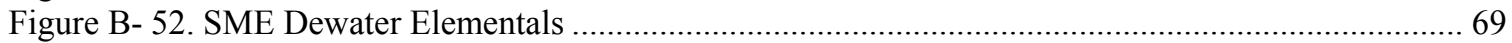

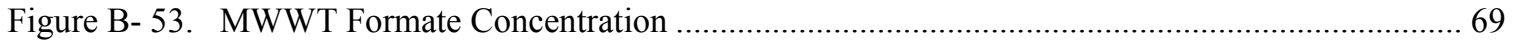

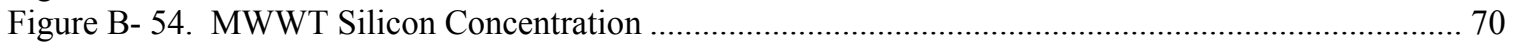

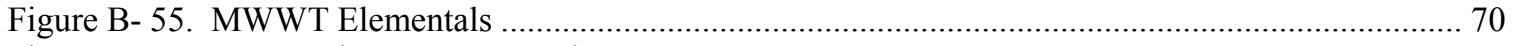

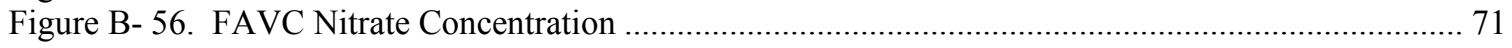

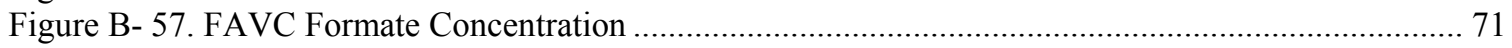

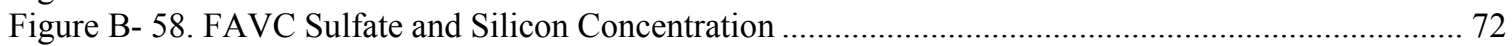

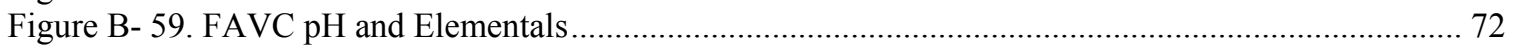

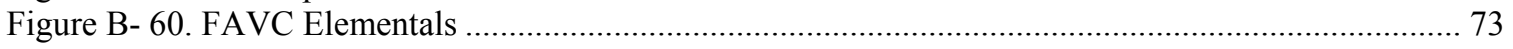

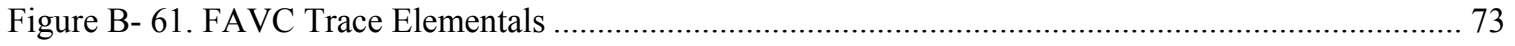

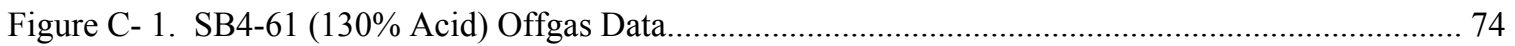

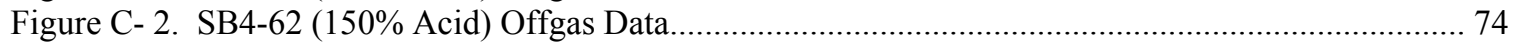

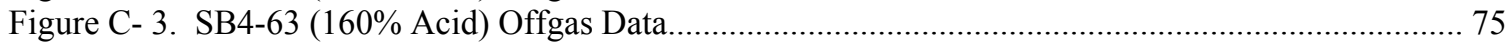

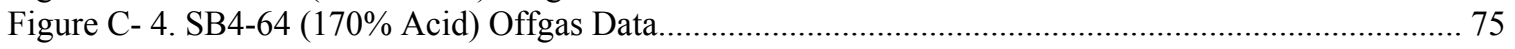

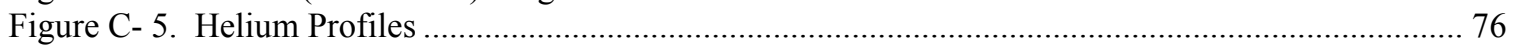

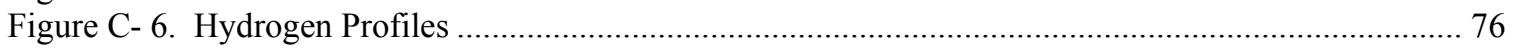

Figure C- 7. Oxygen Profiles............................................................................................................ 77

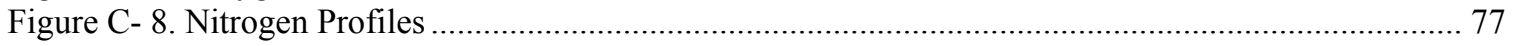

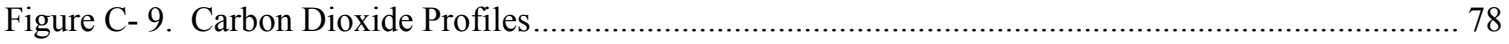

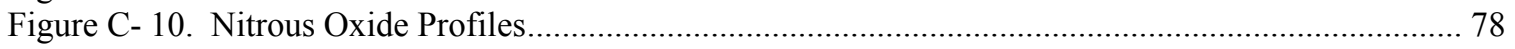

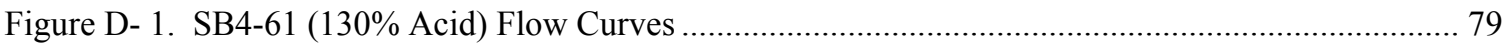

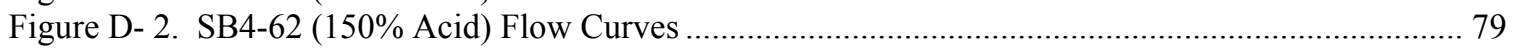

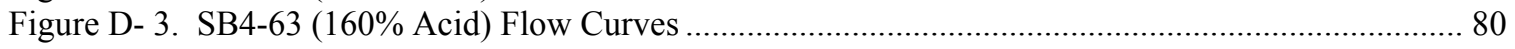

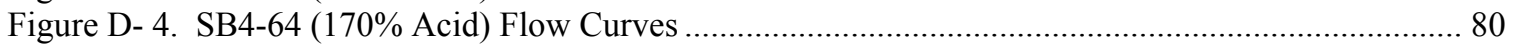

Figure D- 5. SB4-61 (130\% Acid) SME Product Flow Curves................................................................... 81

Figure D- 6. SB4-62 (150\% Acid) SME Product Flow Curves............................................................... 81

Figure D- 7. SB4-63 (160\% Acid) SME Product Flow Curves.................................................................. 82

Figure D- 8. SB4-64 (170\% Acid) SME Product Flow Curves................................................................. 82

Figure D- 9. SB4-62 SME Product Adjusted to $45 \mathrm{wt} \%$ Solids Flow Curves.............................................. 83

Figure D- 10. SB4-62 SME Product Flow Curves After Centrifuging...................................................... 83

Figure D- 11. SB4-62 SME Product Flow Curves after Adjusting to $50 \mathrm{wt} \%$ Solids ................................. 84

Figure D- 12. SB4-62 SME Product Flow Curves after Adjusting to $51 \mathrm{wt} \%$ Solids ................................... 84 


\section{LIST OF TABLES}

Table 1. Simulant Composition for SB4 Flowsheet Testing 2

Table 2. Trim Chemical Additions $\quad 3$

Table 3. SRAT/SME Tests $\quad 7$

Table 4. Sludge Trimming Parameters and Assumptions 8

Table 5. SRAT Cycle Processing Parameters and Assumptions 9

Table 6. SME Processing Parameters and Assumptions 9

Table 7. Selected Process Values 10

Table 8. SRAT and SME Product Mercury Results 14

Table 9. Manganese and Nickel Solubility in SRAT Product 16

Table 10. SRAT Cycle Hydrogen Peak Generation Rate 18

Table 11. SRAT Cycle Nitrous Oxide and Carbon Dioxide Peak Generation Rates 19

Table 12. Rheological Properties of SRAT Products 20

$\begin{array}{ll}\text { Table 13. SME Product Results } & 22\end{array}$

Table 14. SME Cycle Formate / Nitrate Loss 22

Table 15. SME Cycle Hydrogen Peak Generation Rates 25

Table 16. SME Cycle Carbon Dioxide and Nitrous Oxide Peak Generation Rates 25

Table 17. SME Product Rheological Properties 26

Table 18. SME Product Rheology versus Solids Content 27

Table 19. SME Product REDOX 28

Table 20. Offgas Peak Summary 29

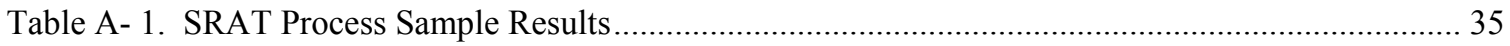

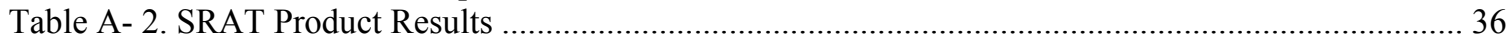

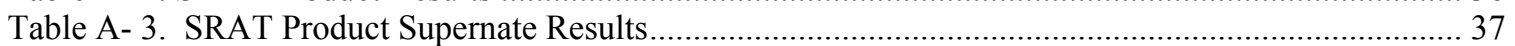

Table A- 4. SME Product Results .................................................................................................. 38

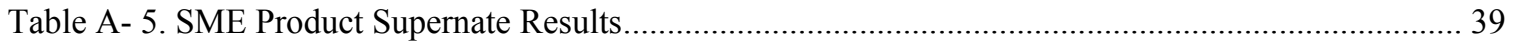

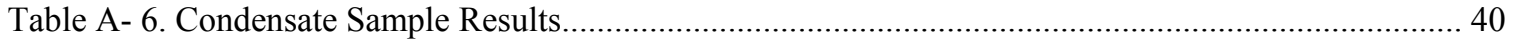

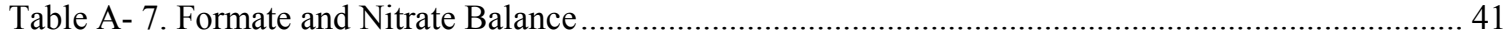

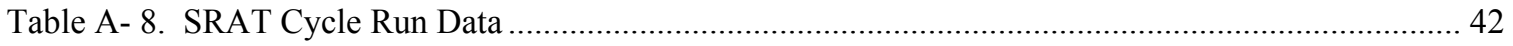

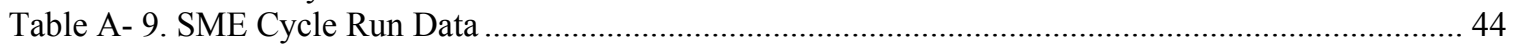

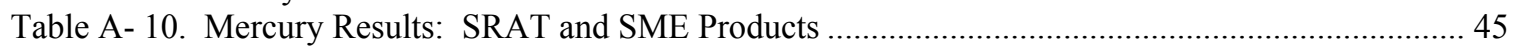

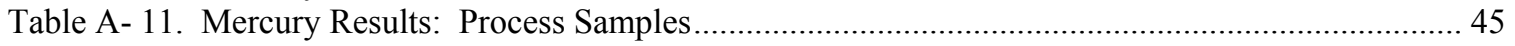




\section{LIST OF ACRONYMS}

$\begin{array}{ll}\text { ACTL } & \text { Aiken County Technologies Laboratory } \\ \text { AD } & \text { Analytical Development } \\ \text { ASP } & \text { Analytical Study Plan } \\ \text { CPC } & \text { Chemical Process Cell } \\ \text { CS } & \text { Calcine Solids } \\ \text { DWPF } & \text { Defense Waste Processing Facility } \\ \text { FAVC } & \text { Formic Acid Vent Condenser } \\ \text { GC } & \text { Gas Chromatograph } \\ \text { HLW } & \text { High Level Waste } \\ \text { IC } & \text { Ion Chromatography } \\ \text { ICP-AES } & \text { Inductively Coupled Plasma - Atomic Emission Spectroscopy } \\ \text { IS } & \text { Insoluble Solids } \\ \text { MWWT } & \text { Mercury Water Wash Tank } \\ \text { PSAL } & \text { Process Science Analytical Laboratory } \\ \text { PSE } & \text { Process Science and Engineering Section } \\ \text { QA } & \text { Quality Assurance } \\ \text { REDOX } & \text { REDuction / OXidation potential } \\ \text { SB3 } & \text { Sludge Batch 3 } \\ \text { SB4 } & \text { Sludge Batch 4 } \\ \text { SME } & \text { Slurry Mix Evaporator } \\ \text { SMECT } & \text { Slurry Mix Evaporator Condensate Tank } \\ \text { SRAT } & \text { Sludge Receipt and Adjustment Tank } \\ \text { SS } & \text { Soluble Solids } \\ \text { TIC } & \text { Total Inorganic Carbon } \\ \text { TS } & \text { Total Solids } \\ \text { TT\&QAP } & \text { Task Technical and Quality Assurance Plan } \\ \text { TTR } & \text { Technical Task Request } \\ & \end{array}$




\subsection{Introduction and Background}

The Defense Waste Processing Facility (DWPF) will transition from Sludge Batch 3 (SB3) processing to Sludge Batch 4 (SB4) processing in early fiscal year 2007. Tests were conducted using non-radioactive simulants of the expected SB4 composition to determine the impact of varying the acid stoichiometry during the Sludge Receipt and Adjustment Tank (SRAT) process. The work was conducted to meet the Technical Task Request (TTR) HLW/DWPF/TTR-2004$0031^{1}$ and followed the guidelines of a Task Technical and Quality Assurance Plan (TT\&QAP) ${ }^{2}$.

The flowsheet studies are performed to evaluate the potential chemical processing issues, hydrogen generation rates, and process slurry rheological properties as a function of acid stoichiometry. Initial SB4 flowsheet studies were conducted to guide decisions during the sludge batch preparation process ${ }^{3,4}$. These studies were conducted with the estimated SB4 composition at the time of the study. The composition has changed slightly since these studies were completed due to changes in the sludges blended to prepare SB4 and the estimated SB3 heel mass.

The following TTR requirements were addressed in this testing:

$>$ Hydrogen and nitrous oxide generation rates as a function of acid stoichiometry

$>$ Acid quantities and processing times required for mercury removal

$>$ Acid quantities and processing times required for nitrite destruction

$>$ Impact of SB4 composition (in particular, oxalate, manganese, nickel, mercury, and aluminum) on DWPF processing (i.e. acid addition strategy, foaming, hydrogen generation, REDOX control, rheology, etc.) 


\subsection{Approach}

Four SRAT/SME runs were completed during this study using acid stoichiometries of $130 \%$, $150 \%, 160 \%$ and $170 \%$. These runs were completed and samples analyzed using the practices and procedures typical for Chemical Process Cell (CPC) simulations at the Aiken County Technology Laboratory (ACTL), as described below.

\subsection{Simulant Preparation}

The simulant was based on the composition estimate for the $15 \mathrm{C}$ Blend 1 option $^{5}$ in January 2006. Simulant was prepared by blending the Spintek simulant ${ }^{6}$ with precursors-based simulant ${ }^{3}$. Composition of the simulant is shown in Table 1. The simulant matches the expected SB4 composition to within $15 \%$ for major species and was deemed to be acceptable for testing based on engineering judgment. The composition estimates for SB4 were revised in June $2006^{\mathrm{a}}$, but the revised compositions did not vary from the earlier estimates sufficiently to warrant a new recipe for the sludge simulant.

Table 1. Simulant Composition for SB4 Flowsheet Testing

\begin{tabular}{|c|c|c|c|c|}
\hline Elemental & Wt\% calcined solids & $\begin{array}{l}\text { June } 2006 \\
\text { Estimates }\end{array}$ & Solids Data & Wt \% \\
\hline $\mathrm{Al}$ & 14.31 & 12.60 & Total & 17.36 \\
\hline $\mathrm{Ba}$ & 0.16 & 0.11 & Insoluble & 11.92 \\
\hline $\mathrm{Ca}$ & 1.85 & 1.68 & Soluble & 5.45 \\
\hline $\mathrm{Cr}$ & 0.14 & 0.14 & Calcined & 12.41 \\
\hline $\mathrm{Cu}$ & 0.06 & 0.05 & Anions & $\mathrm{mg} / \mathrm{Kg}$ \\
\hline $\mathrm{Fe}$ & 17.85 & 18.34 & Chloride & 141 \\
\hline $\mathrm{K}$ & 0.25 & 0.27 & Nitrite & 14495 \\
\hline $\mathrm{Mg}$ & 1.37 & 1.50 & Nitrate & 9331 \\
\hline $\mathrm{Mn}$ & 4.05 & 4.19 & Formate & $<100$ \\
\hline $\mathrm{Na}$ & 15.15 & 17.76 & Sulfate & 1537 \\
\hline $\mathrm{Ni}$ & 1.39 & 1.22 & Oxalate & 622 \\
\hline $\mathrm{P}$ & 0.03 & $\mathrm{n} / \mathrm{a}$ & Phosphate & $<100$ \\
\hline $\mathrm{Pb}$ & $<0.020$ & 0.08 & Carbonate & 1,157 \\
\hline $\mathrm{S}$ & 0.38 & $\mathrm{n} / \mathrm{a}$ & Other Results & \\
\hline $\mathrm{Si}$ & 1.75 & 1.86 & $\begin{array}{c}\text { Base Equivalents } \\
\text { (molar) }\end{array}$ & 0.443 \\
\hline $\mathrm{Ti}$ & 0.03 & 0.02 & Density $(\mathrm{g} / \mathrm{ml})$ & 1.138 \\
\hline $\mathrm{Zn}$ & 0.17 & 0.08 & $\mathrm{pH}$ & 12.75 \\
\hline \multirow[t]{3}{*}{$\mathrm{Zr}$} & 0.21 & 0.17 & $\begin{array}{c}\text { Rheological } \\
\text { Properties }\end{array}$ & \\
\hline & & & Yield Stress $(\mathrm{Pa})$ & 8.82 \\
\hline & & & Consistency (cP) & 7.3 \\
\hline
\end{tabular}

Noble metals, mercury, and rinse water were added to the sludge simulant prior to performing the SRAT cycle. Samples were not taken after the additions as the amount of these additions is small compared to the sludge. The noble metal concentrations were based on $125 \%$ of the estimated

${ }^{\text {a }}$ E-mail message from H. B. Shah to C. C. Herman dated 6/22/06. 
amount in the sludge batch ${ }^{7}$ after transfer onto the heel of SB3. The concentrations of each trim chemical added are shown in Table 2.

Table 2. Trim Chemical Additions

\begin{tabular}{||c|c||}
\hline Trim Chemical & Wt\% in Total Solids \\
\hline Hg & 1.0 \\
\hline Ag & 0.0112 \\
\hline Pd & 0.0015 \\
\hline Rh & 0.0108 \\
\hline Ru & 0.0493 \\
\hline
\end{tabular}

\subsection{Experimental Apparatus}

The testing was performed at the ACTL using the four-liter kettle setup. The SRAT rigs were assembled following the guidelines of SRNL-PSE-2006-00074 ${ }^{8}$. The intent of the equipment is to functionally replicate the DWPF processing vessels. The 4-liter glass kettle is used to replicate both the SRAT and the SME, and it is connected to the SRAT Condenser, the Mercury Water Wash Tank (MWWT), and the Formic Acid Vent Condenser (FAVC). The Slurry Mix Evaporator Condensate Tank (SMECT) is represented by a sampling bottle that is used to remove condensate through the MWWT. For the purposes of this paper, the condensers and wash tank are referred to as the offgas components. A sketch of the experimental setup is given as Figure 1 . 


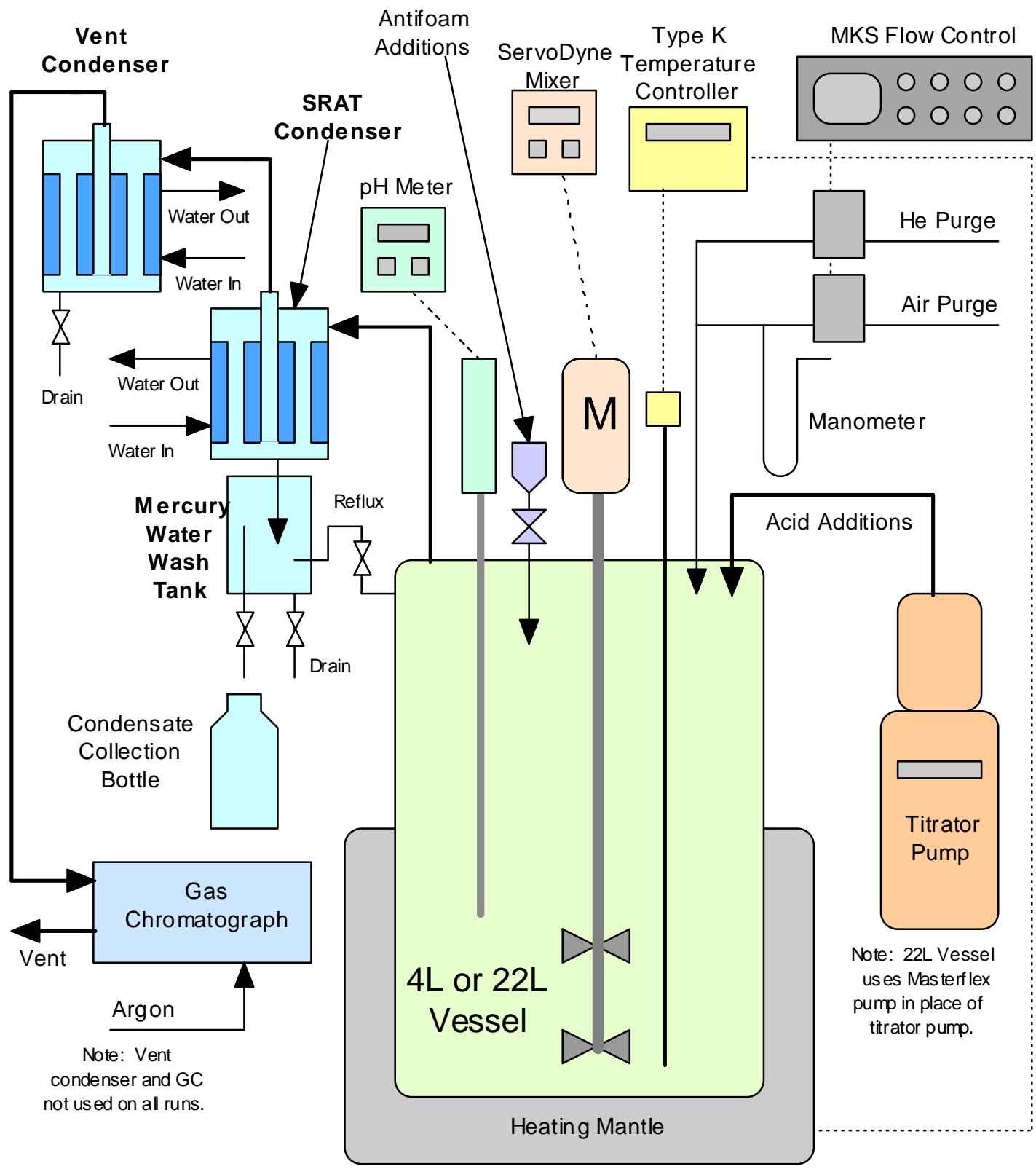

Figure 1. Schematic of SRAT Equipment Set-Up

SRAT and SME processing parameters are summarized in Appendix A. The flowsheet runs were performed using the guidance of Procedure ITS-0094 ("Laboratory Scale Chemical Process Cell Simulations") of Manual L29 . Offgas hydrogen, oxygen, nitrogen, nitrous oxide, and carbon dioxide concentrations were measured during the experiments using in-line instrumentation. Helium was introduced at a concentration of $0.5 \%$ of the total air purge as an inert tracer gas so that total amounts of generated gas and peak generation rates could be calculated. During the runs, the kettle was monitored to observe reactions that were occurring to include foaming, air entrainment, rheology changes, loss of heat transfer capabilities, and offgas carryover. Observations were recorded in laboratory notebook WSRC-NB-2006-00087 $7^{10}$ and are discussed in Section 3.0. 
Concentrated nitric acid (50-wt $\%)$ and formic acid $(90-\mathrm{wt} \%)$ were used to acidify the sludge and perform neutralization and reduction reactions during processing. The amounts of acid to add for each run were determined using the existing DWPF acid addition equation ${ }^{11}$. The split of the acid was determined using the redox equation currently being used in DWPF processing ${ }^{12}$ with a slight modification for the manganese term. The redox target $\left(\mathrm{Fe}^{2+} / \Sigma \mathrm{Fe}\right)$ was 0.2 . To account for the reactions and anion destructions that occur during processing, assumptions about nitrite destruction, nitrite to nitrate conversion, and formate destruction were made for each run. The values used for each run are provided in Section 3.0.

To prevent foaming during processing, $200 \mathrm{ppm}$ IIT 747 antifoam was added during heat-up at $40^{\circ} \mathrm{C}$ and $500 \mathrm{ppm}$ was added at the completion of acid addition. The addition strategy was conservative relative to the current DWPF addition strategy to increase sensitivity to foaming issues, and no recommendations on changes to the antifoam addition strategy will be made based on this testing. SRAT processing included the dewater time in boiling plus an additional 12 hours of reflux to simulate DWPF processing conditions. SME processing did not include the addition of canister dewaters. The frit addition was split into two equal portions. The frit was added with water and formic acid at DWPF prototypical conditions. Concentration was performed after each frit addition and then heat was removed to allow for the next frit addition A final concentration was performed at the end of the run to meet the target total solids. The SRAT condenser was maintained at $25^{\circ} \mathrm{C}$ during the run while the vent condenser was maintained at $4^{\circ} \mathrm{C}$.

\subsection{Analytical Methods}

Analyses for this task used guidance of Analytical Study Plan (ASP) SRNL-GPD-2005-00001 ${ }^{13}$. Sample request forms were used for samples to be analyzed, and analyses followed the guidelines and means of sample control stated in the ASP for the task. A unique lab identification number was assigned to each sample for tracking purposes. Analyses were performed using approved analytical and Quality Assurance (QA) procedures.

The sludge simulant was analyzed as part of the sludge fabrication process; therefore, those results were used to support this testing and no discussion of the methods will be presented here. Samples were taken throughout the run and of the SRAT and SME products to evaluate the process chemistry. In-process supernate and slurry samples were taken in both of the runs to help support programs focused on understanding the SRAT chemical reactions. The samples were analyzed at the Process Science Analytical Laboratory (PSAL) and Analytical Development (AD). The PSAL performed analyses on the in-process and product samples to determine the chemical composition, total and dissolved solids, density, and $\mathrm{pH}$. The chemical composition was determined in duplicate by calcining the samples at $1100^{\circ} \mathrm{C}$ and then dissolving the product using $\mathrm{Na}_{2} \mathrm{O}_{2} / \mathrm{NaOH}$ fusion and a lithium metaborate fusion. The preparations were then analyzed using Inductively Coupled Plasma - Atomic Emission Spectroscopy (ICP-AES) to measure the cations present.

The in-process samples were centrifuged immediately after pulling the samples from the SRAT vessel in an attempt to stop the reactions occurring with the other solids. The centrifuged supernates were analyzed by ICP-AES. For the SRAT products, the products were filtered using a $0.45 \mu \mathrm{m}$ filter and the separated supernates were analyzed using ICP-AES to determine the soluble cations present. Sludge samples for anion analyses were prepped using weighted dilutions and were analyzed using Ion Chromatography (IC). The in-process supernates were also analyzed on the IC to determine the soluble anions. The total and dissolved solids were measured on two aliquots and the insoluble and soluble solids fractions were calculated from the 
results. Density and $\mathrm{pH}$ measurements of the samples were also performed on the in-process samples. Rheological properties of the SRAT and SME products (yield stress and plastic viscosity) were measured and evaluated as a function of the test conditions.

Gases were monitored during the runs using a high-speed Agilent model 3000 micro Gas Chromatograph (GC) to provide insight into the reactions occurring during processing and to determine whether a flammable mixture was formed. As mentioned above, helium was used as a purge gas tracer. Two calibration standards were used to calibrate the GCs before each run to attempt to bound the quantities of the expected gases. The concentrations of these calibration standards were $0.5 \mathrm{~mol} \%$ helium, 0 and $1 \mathrm{~mol} \%$ hydrogen, 0 and $21 \%$ oxygen, 55 and $66.5 \mathrm{~mol} \%$ nitrogen, $2.5 \mathrm{~mol} \%$ nitrous oxide, $0.5 \mathrm{~mol} \%$ carbon monoxide, $20 \mathrm{~mol} \%$ carbon dioxide, and 0 and $10 \mathrm{~mol} \%$ nitric oxide. Calibration checks were performed before and after each run.

The GC is self-contained and is designed specifically for fast and accurate analysis. The GCs have five main components. The first is the carrier gas (argon for this testing) to transport the sample through the MolSieve 5A PLOT (Channel A) and PLOT Q (Channel B) columns. The second is the injector, which introduces a measured amount of sample into the inlet of the analytical columns where it is separated. Injection time is 50 milliseconds for the Channel A gases (helium, hydrogen, nitrogen, oxygen, nitric oxide and carbon monoxide) and 100 milliseconds for the Channel B gases (carbon dioxide and nitrous oxide). The third component is the column, which is capillary tubing coated or packed with a chemical substance known as the stationary phase that preferentially attracts the sample components. As a result, components separate as they pass through the column based on their solubility. Since solubility is affected by temperature, column temperature is controlled during the run. The Channel A column is set at $60^{\circ} \mathrm{C}$, while the Channel $\mathrm{B}$ column is set at $70^{\circ} \mathrm{C}$. The fourth component is a micro-machine thermo conductivity detector. The solid state detector monitors the carrier and senses a change in its composition when a component in the sample elutes from the column. The fifth component is the data system, Cerity. Its main purpose is to generate both qualitative and quantitative data. It provides a visual recording of the detector output and an area count of the detector response. The detector response is used to identify the sample composition and measure the amount of each component by comparing the area counts of the sample to the analysis of known calibration standards. A sample was taken approximately once every 3 minutes.

The Total Inorganic Carbon (TIC), mercury, and Semi-Volatile Organic Analysis (SVOA) analysis were performed by Analytical Development. TIC was analyzed with an OI 1010 High Temperature Total Carbon Analyzer. Mercury was analyzed using Atomic Adsoption Spectroscopy following an aqua regia preparation. SVOA analysis was performed using a Gas Chromatograph-Mass Spectrometer. 


\subsection{Results}

Four SRAT/SME cycles were conducted during this study, as shown in Table 3. A unique run number was assigned to each run ${ }^{14,15,16,17}$. All runs targeted a predicted glass REDOX of 0.2 by adjusting the ratio of formic to nitric acid during the SRAT cycle and assumed a coefficient of five for the manganese term in the REDOX prediction. Frit 503 was utilized during the SME cycle and a waste loading of $35 \%$ was targeted.

Table 3. SRAT/SME Tests

\begin{tabular}{||c|c|c|c|c||}
\hline $\begin{array}{c}\text { RUN } \\
\text { NUMBER }\end{array}$ & $\begin{array}{c}\text { ACID } \\
\text { STOICHIOMETRY }\end{array}$ & $\begin{array}{c}\text { REDOX } \\
\text { TARGET }\end{array}$ & $\begin{array}{c}\text { PROCESS } \\
\text { FRIT }\end{array}$ & $\begin{array}{c}\text { WASTE } \\
\text { LOADING }\end{array}$ \\
\hline SB4-61 & $130 \%$ & 0.2 & 503 & 35 \\
\hline SB4-62 & $150 \%$ & 0.2 & 503 & 35 \\
\hline SB4-63 & $160 \%$ & 0.2 & 503 & 35 \\
\hline SB4-64 & $170 \%$ & 0.2 & 503 & 35 \\
\hline
\end{tabular}

\subsection{SRAT Cycle Results}

\subsubsection{Acid Addition Calculation}

\subsubsection{Calculation Inputs}

The SRAT cycle acid calculation utilizes the amount of nitrite, mercury, manganese, carbonate, and base equivalents to calculate the stoichiometric amount of acid to be added. Nitric acid and formic acid amounts are calculated ${ }^{11}$ based on the applied stoichiometric factor and the ratio needed to achieve the predicted glass redox target of $0.2 \mathrm{Fe}^{+2} / \Sigma \mathrm{Fe}$. The equation for prediction of glass redox utilizes estimates of the amount of formate, oxalate, nitrate, nitrite, manganese, and total solids in the SME product. The estimation of the final concentration for the anions require assumptions to be made concerning how these species will react during the SRAT and SME cycles. Formate and oxalate are destroyed by reactions with oxidizing species and by catalytic reactions with noble metals. Nitrite is typically consumed during acid additions, but can react to form different species including nitrate. The acid calculation inputs and assumptions are shown in Table 4, Table 5, and Table 6 for SB4-61. The same assumptions and inputs were used for all four runs, with the exception of the acid stoichiometry. 
WSRC-STI-2006-00109

Revision 0

Table 4. Sludge Trimming Parameters and Assumptions

\begin{tabular}{||l|c|c||}
\hline Description & Units & SB4-61 \\
\hline Fresh Sludge Mass without trim chemicals & $\mathrm{g}$ slurry & $2,845.0$ \\
\hline Fresh Sludge Weight \% Total Solids & $\mathrm{wt} \%$ & 17.36 \\
\hline Fresh Sludge Weight \% Calcined Solids & $\mathrm{wt} \%$ & 12.41 \\
\hline Fresh Sludge Weight \% Insoluble Solids & $\mathrm{wt} \%$ & 11.92 \\
\hline Fresh Sludge Density & $\mathrm{kg} / \mathrm{L}$ slurry & 1.138 \\
\hline Fresh Sludge Nitrite & $\mathrm{mg} / \mathrm{kg}$ slurry & 14,495 \\
\hline Fresh Sludge Nitrate & $\mathrm{mg} / \mathrm{kg}$ slurry & 9,331 \\
\hline Fresh Sludge Oxalate & $\mathrm{mg} / \mathrm{kg}$ slurry & 622 \\
\hline Fresh Sludge Formate & $\mathrm{wt} \%$ calcined basis & 0 \\
\hline Fresh Sludge Manganese (\% of Calcined Solids) & $\mathrm{mg} / \mathrm{kg}$ slurry & 1,046 \\
\hline Fresh Sludge Slurry TIC (treated as Carbonate) & Equiv Moles Base/L & 0.443 \\
\hline Fresh Sludge Hydroxide (Base Equivalents) pH $=7$ & $\mathrm{wt} \%$ dry basis & 0.00 \\
\hline Fresh Sludge Mercury (\% of Total Solids in untrimmed sludge) & $\mathrm{mg} / \mathrm{L}$ supernate & 0 \\
\hline Fresh Sludge Supernate manganese & $\mathrm{kg} / \mathrm{L}$ supernate & 1.04 \\
\hline Fresh Sludge Supernate density & & 0 \\
\hline
\end{tabular}


WSRC-STI-2006-00109

Revision 0

Table 5. SRAT Cycle Processing Parameters and Assumptions

\begin{tabular}{|c|c|c|}
\hline Description & 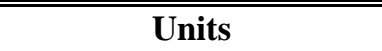 & SB4-61 \\
\hline Conversion of Nitrite to Nitrate in SRAT Cycle & $\mathrm{gmol} \mathrm{NO}_{3}{ }^{-} / 100 \mathrm{gmol} \mathrm{NO}_{2}^{-}$ & 15.00 \\
\hline Destruction of Nitrite in SRAT and SME cycle & $\%$ of starting nitrite & 100.00 \\
\hline Destruction of Formic acid charged in SRAT & $\%$ & 25.00 \\
\hline Destruction of oxalate charged & $\%$ & 50.00 \\
\hline Percent Acid in Excess Stoichiometric Ratio & $\%$ & 130.00 \\
\hline SRAT Product Target Solids & $\%$ & 25.00 \\
\hline Nitric Acid Molarity & Molar & 10.573 \\
\hline Formic Acid Molarity & Molar & 23.604 \\
\hline DWPF Nitric Acid addition Rate & gallons per minute & 2.0 \\
\hline DWPF Formic Acid addition Rate & gallons per minute & 2.0 \\
\hline REDOX Target & $\mathrm{Fe}^{+2} / \Sigma \mathrm{Fe}$ & 0.200 \\
\hline REDOX Equation (7 for $\mathrm{Mn}^{+7}$, otherwise assumes $\mathrm{Mn}^{+4}$ ) & & 7 \\
\hline Trimmed Sludge Target Ag metal content & total $\mathrm{wt}^{\%} \%$ dry basis & 0.011200 \\
\hline Trimmed Sludge Target $\mathrm{wt} \% \mathrm{Hg}$ dry basis & total $w t \%$ dry basis & 1.0000 \\
\hline Trimmed Sludge Target Pd metal content & total $w \mathrm{t} \%$ dry basis & 0.0015 \\
\hline Trimmed Sludge Target Rh metal content & total $\mathrm{wt} \%$ dry basis & 0.0108 \\
\hline Trimmed Sludge Target Ru metal content & total $\mathrm{wt} \%$ dry basis & 0.0493 \\
\hline Trimmed Sludge Target oxalate after trim (wt \% not mg/kg) & total $\mathrm{wt} \%$ dry basis & 0.3530 \\
\hline Water to dilute fresh sludge and/or rinse trim chemicals & $\mathrm{g}$ & 50.00 \\
\hline Sample Mass of Trimmed sludge (SRAT Receipt sample, if any) & $\mathrm{g}$ & 0.00 \\
\hline Mass of SRAT cycle samples & $\mathrm{g}$ & 250.00 \\
\hline $\mathrm{Wt} \%$ Active Agent In Antifoam Solution & $\%$ & 10 \\
\hline $\begin{array}{l}\text { Basis Antifoam Addition for SRAT (generally } 100 \mathrm{mg} \\
\text { antifoam/kg slurry) }\end{array}$ & $\mathrm{mg} / \mathrm{kg}$ slurry & 100 \\
\hline \multicolumn{2}{|l|}{ Number of basis antifoam additions added during SRAT cycle } & 7 \\
\hline
\end{tabular}

Table 6. SME Processing Parameters and Assumptions

\begin{tabular}{|c|c|c|}
\hline Description & Units & SB4-61 \\
\hline Frit type & & 503 \\
\hline Destruction of Formic acid in SME & $\%$ & 8.00 \\
\hline Destruction of Nitrate in SME & $\%$ & 5.00 \\
\hline Assumed SME density & $\mathrm{kg} / \mathrm{L}$ & 1.450 \\
\hline Basis Antifoam Addition for SME cycle & $\mathrm{mg} / \mathrm{kg}$ slurry & 100 \\
\hline \multicolumn{2}{|c|}{ Number of basis antifoam additions added during SME cycle } & 7 \\
\hline Sludge Oxide Contribution in SME (Waste Loading) & $\%$ & 35.00 \\
\hline Frit Slurry Formic Acid Ratio & g $90 \mathrm{wt} \% \mathrm{FA} / 100 \mathrm{~g}$ Frit & 1.50 \\
\hline Target SME Solids total $\mathrm{Wt} \%$ & wt $\%$ & 45.0 \\
\hline Number of frit additions in SME Cycle & & 2 \\
\hline
\end{tabular}

\subsubsection{Acid Calculation Results}

The acid calculation determines the values for a large number of processing parameters as well as the amount of formic and nitric acid to be used. Selected values are shown in Table 7 with all 
values tabulated in Appendix A and selected values graphically shown in Appendix B. The stoichiometry acid addition for the sludge simulant was calculated to be 1.07 moles per liter. As acid stoichiometry increased, the ratio of formic acid to the total amount of acid decreased. This decrease is due to the presence of nitrate and nitrite in the initial sludge simulant lowering the amount of nitrate needed to balance the formic acid at lower acid stoichiometries. The frit addition increased slightly due to the process samples being more dilute in terms of the original feed as acid stoichiometry increased.

Table 7. Selected Process Values

\begin{tabular}{||c|c|c|c||}
\hline $\begin{array}{c}\text { ACID } \\
\text { STOICHIOMETRY }\end{array}$ & $\begin{array}{c}\text { TOTAL ACID } \\
\text { REQUIRED } \\
\text { (MOL/L) }\end{array}$ & $\begin{array}{c}\text { FORMIC ACID RATIO } \\
\text { (\% OF TOTAL ACID) }\end{array}$ & $\begin{array}{c}\text { FRIT ADDITION } \\
\text { AMOUNT } \\
\text { (GRAMS) }\end{array}$ \\
\hline $130 \%$ & 1.388 & 94.77 & 583.8 \\
\hline $150 \%$ & 1.601 & 92.47 & 586.6 \\
\hline $160 \%$ & 1.708 & 91.55 & 587.8 \\
\hline $170 \%$ & 1.815 & 90.71 & 589.0 \\
\hline
\end{tabular}

\subsubsection{Processing Observations}

Overall processing during the testing went smoothly with no interruptions or upsets occurring during process runs. The sludge became less viscous during acid additions and no problems were noted with mixing during the runs. Agitator speeds of $350 \mathrm{RPM}^{\mathrm{b}}$ were needed to mix the sludge simulants. The agitator speed was reduced to $250 \mathrm{RPM}$ during acid addition to reduce the size of the central vortex. This speed was maintained for the remainder of the SRAT cycle for all runs except for SB4-61 (130\% acid). The agitator speed was increased to 320 RPM after dewater to maintain a vortex. During this run, mercury beads were noted on the agitator shaft and impellers after the SME cycle similar to (but less than) the accumulation seen during the SB4 qualification testing with simulants. Mercury accumulation was not noted during the other three runs.

\subsubsection{Foaming}

Additional antifoam (100 ppm) was required during the formic acid addition for two of the runs (SB4-61 and SB4-63). The antifoam protocol used during DWPF operation has an additional 100 ppm antifoam addition between the nitric and formic additions that was not performed during simulant testing. The extra antifoam addition (one $100 \mathrm{ppm}$ addition) made to each run resulted in the total antifoam addition matching the amount of antifoam that would be added at DWPF.

\subsubsection{2 pH Profiles}

The $\mathrm{pH}$ profiles of the four runs in general matched profiles noted during previous CPC simulations ${ }^{4}$. As shown in Figure 2, the $\mathrm{pH}$ of the runs was lower for runs with higher acid additions. Formic acid decomposition during high acid runs can result in lower $\mathrm{pH}$ at higher acid stoichiometries, but the decomposition noted during the flowsheet testing was not high enough to raise the $\mathrm{pH}$ of the higher acid runs above the lower acid runs. All three runs with acid stoichiometries above $130 \%$ had a minimum $\mathrm{pH}$ near 4.0 at the end of acid addition.

\footnotetext{
${ }^{\mathrm{b}}$ The mixing geometry of the lab-scale apparatus is not prototypic and mixing was adjusted as required during testing to ensure that the process chemistry is captured. Agitator speed is reported only to give an indication of changes in rheological properties during the testing.
} 
WSRC-STI-2006-00109

Revision 0

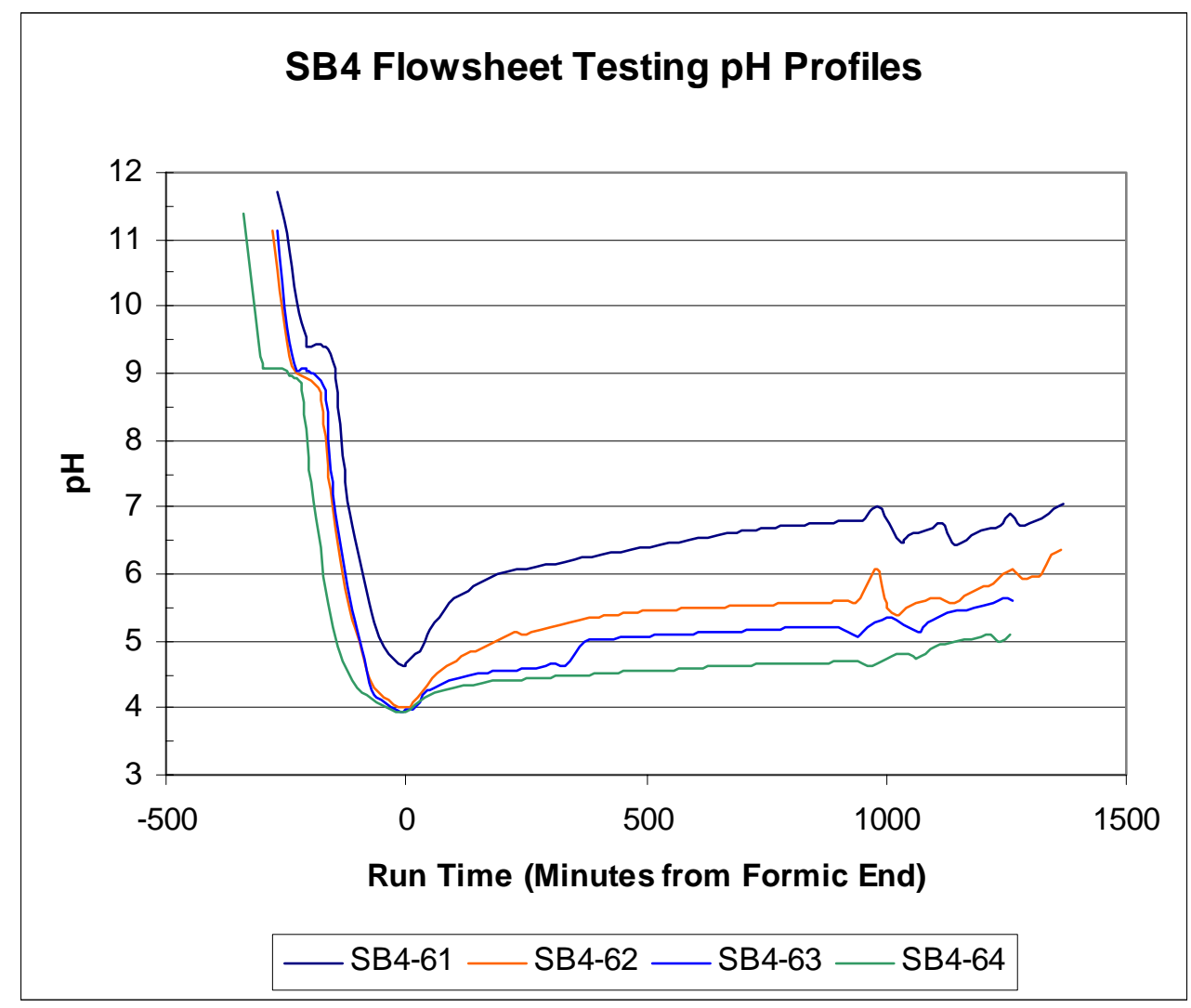

Figure 2. SB4 Flowsheet Testing pH Profiles

\subsubsection{SRAT Cycle Sample Results}

Samples were pulled during the SRAT cycle after acid addition was completed, at the onset of hydrogen generation ${ }^{c}$, at the peak of hydrogen generation, and at the conclusion of the SRAT cycle. The total solids, anions, and soluble elemental species were analyzed for all samples. Mercury analysis was performed on all samples except after acid addition. Samples were taken of the SRAT dewater and the MWWT contents at the completion of the SRAT cycle. All sample results are tabulated in Appendix A while graphical presentations are shown in Appendix B.

\subsubsection{Nitrite}

Nitrite destruction met the process requirement of $<1000 \mathrm{mg} / \mathrm{kg}$ at the end of the SRAT cycle for all runs and was $100 \%$ complete for all runs except SB4-61, as shown in Figure 3. Higher acid stoichiometries led to more rapid destruction of nitrite while nitrite destruction at $130 \%$ acid was not $100 \%$ complete (i.e., still above the detection limit) at the end of the SME cycle.

\footnotetext{
${ }^{c}$ SB4-61 (130\%) did not have samples for the hydrogen onset and hydrogen peak as no hydrogen generation was noted after the completion of acid addition.
} 
WSRC-STI-2006-00109

Revision 0

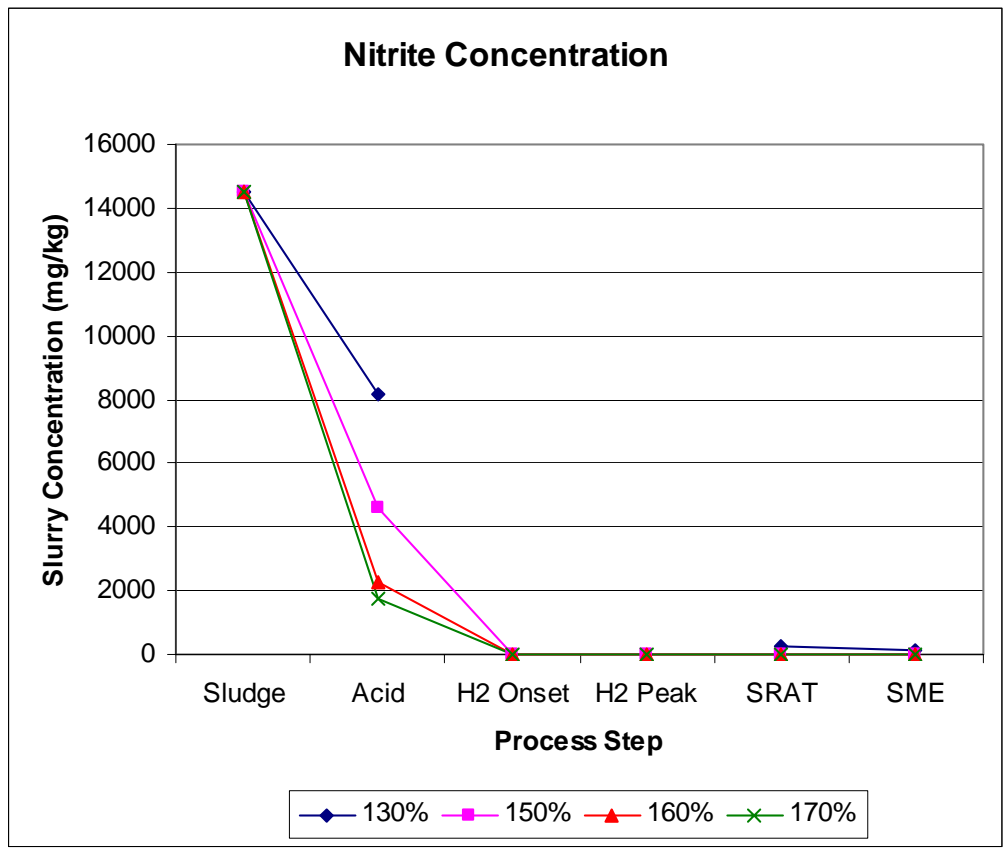

Figure 3. Nitrite Concentration Profile

Conversion of nitrite to nitrate indicated a trend of higher conversions of nitrite to nitrate as the acid stoichiometry was increased, as shown in Figure 4.

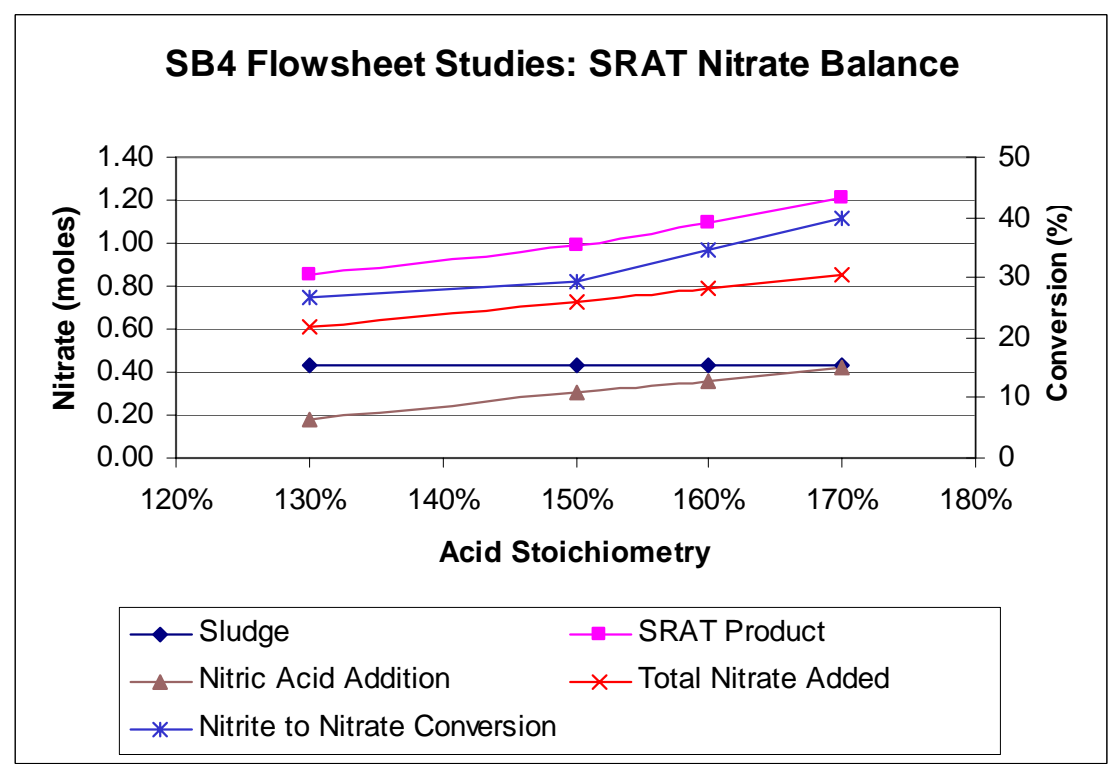

Figure 4. SRAT Nitrate Balance

\subsubsection{Formate}

Formate destruction during the runs is shown in Figure 5. An overall trend of higher formate loss with higher acid stoichiometry is indicated which matches previous results and the amount of formate loss is consistent with previous testing ${ }^{4}$. 
WSRC-STI-2006-00109

Revision 0

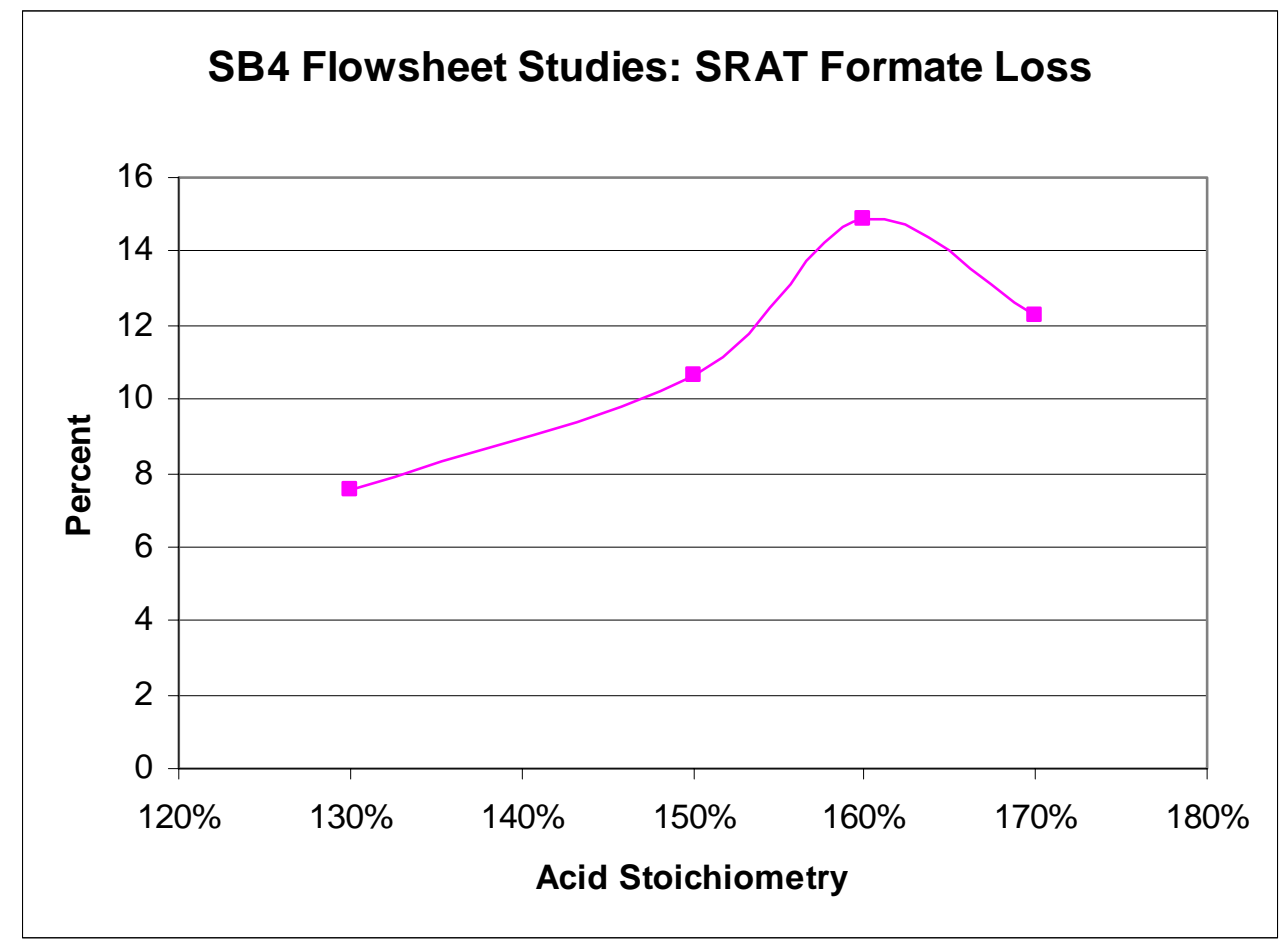

Figure 5. SRAT Cycle Formate Destruction

\subsubsection{Oxalate}

Initial oxalate concentration in the simulant was approximately $600 \mathrm{ppm}$. No oxalate was noted in any of the SRAT product samples, as shown in Figure 6. The amount of oxalate noted in the $130 \%$ acid SME product is just above the minimum sensitivity of the sample analysis.

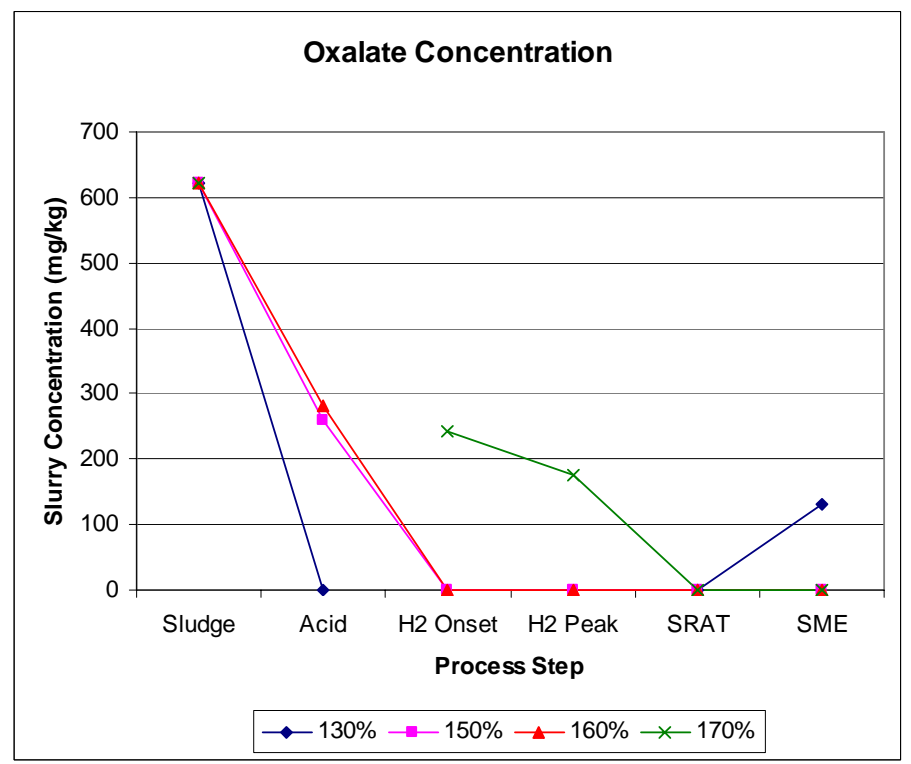

Figure 6. Oxalate Concentration Profile 


\subsubsection{Mercury}

The SRAT product and process samples were analyzed for mercury content to evaluate the stripping of mercury during the SRAT cycle. The SRAT product must be below $0.45 \mathrm{wt} \%$ (solids basis) mercury to meet process specifications. Previous sludge batches met this requirement without mercury removal, but SB4 is estimated to contain approximately $1.0 \mathrm{wt} \%$ mercury in the incoming blended feed. As shown in Table 8, the mercury was reduced to acceptable levels by the end of the SRAT cycle for all runs. The samples taken during the SRAT cycle had considerable variability in the $\mathrm{Hg}$ results and some results indicated more mercury than was added to the sludge, as shown in Figure 7 . The scatter in these process sample results is likely the result of the small sample size and the difficulty in taking a representative sample when elemental mercury is present.

The mercury data indicates that the experimental setup may have an impact on the results. Two setups were used during the testing: Rig 1 and Rig 2. The two rigs were made with identical setups, but the use of custom glass fabrication for the vessel, lid, and offgas components cause slight variations between the rigs. The $130 \%$ and $160 \%$ were performed in the Rig 1 while the $150 \%$ and $170 \%$ runs were performed in Rig 2 . The results for the runs performed in the same rig are very similar; however, the amount of scatter and sampling error typical for mercury analysis would make conclusions from only four runs highly speculative.

Table 8. SRAT and SME Product Mercury Results

\begin{tabular}{||c|c|c||}
\hline \hline ACID STOICHIOMETRY & SRAT PRODUCT & SME PRODUCT \\
\hline$\%$ & $\mathrm{wt} \%$ (solids basis) & $\mathrm{wt} \%$ (solids basis) \\
\hline 130 & 0.256 & 0.088 \\
\hline 150 & 0.340 & 0.189 \\
\hline 160 & 0.245 & 0.097 \\
\hline 170 & 0.385 & 0.138 \\
\hline
\end{tabular}


WSRC-STI-2006-00109

Revision 0

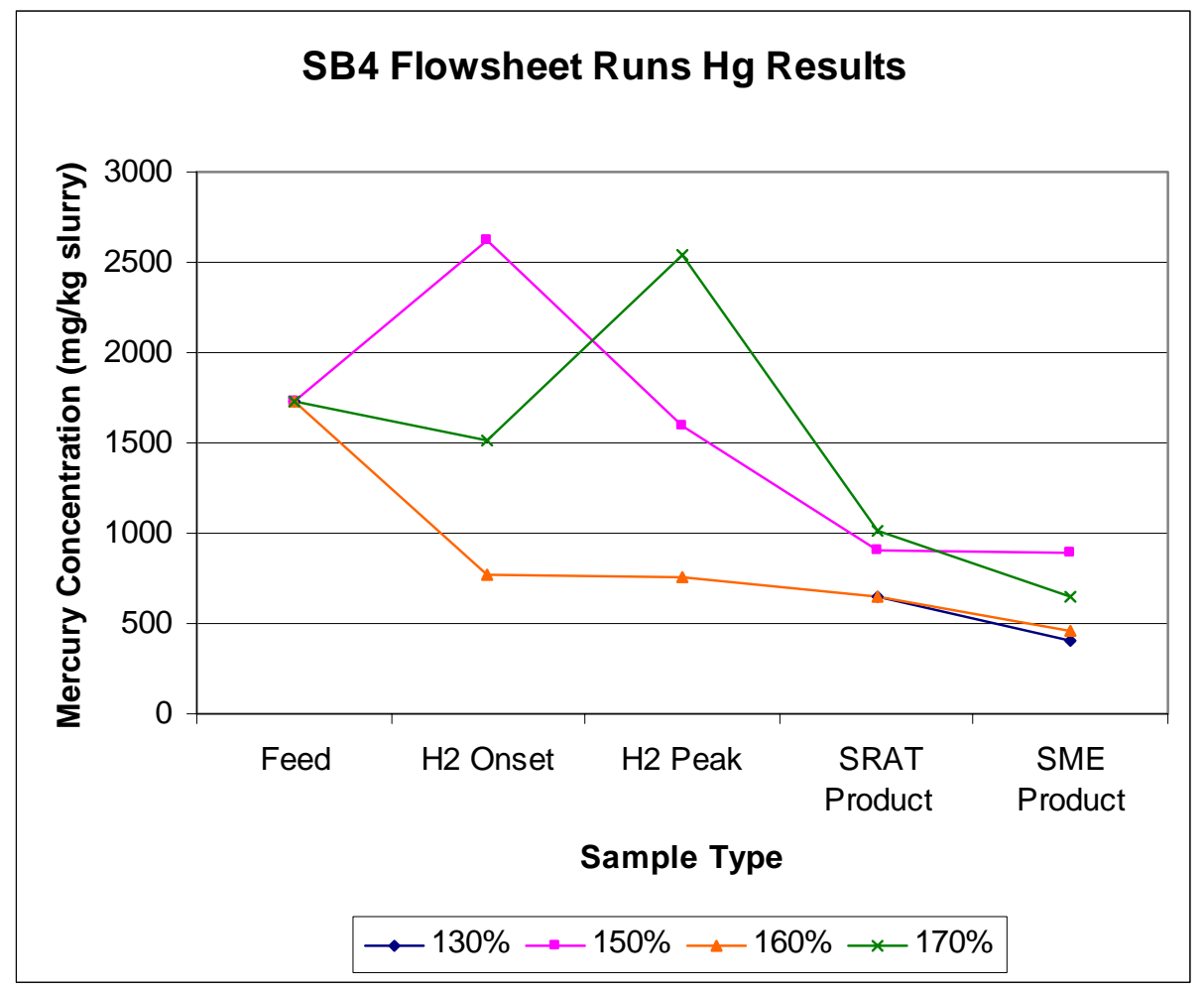

Figure 7. Mercury Results

\subsubsection{Soluble Species}

The amount of soluble metal species present in the SRAT samples is an indirect measurement of the effectiveness of the acid addition and provides data to allow the process chemistry to be evaluated. The percentage soluble for each species was calculated by dividing the amount of the species in the supernate by the amount of the species in the total slurry. The overall trend for most species (phosphorus and palladium being exceptions) is higher solubility as acid stoichiometry is increased. Most species indicated a maximum in soluble concentration after acid addition with decreased solubility as the $\mathrm{pH}$ rose during the dewater and reflux steps. Calcium, magnesium, potassium, sodium, and sulfur were mostly soluble in the SRAT products. Several species $(\mathrm{Ba}, \mathrm{Ni}, \mathrm{Pb}$, and $\mathrm{Zn}$ ) exhibited peaks in solubility at the peak of hydrogen generation. Silicon solubility was likely strongly influenced by antifoam additions and subsequent breakdown. Iron solubility was significantly higher than noted in previous CPC testing. Solubility charts for each species as a function of process step are shown in Appendix B.

Manganese is insoluble when in the $\mathrm{Mn}^{+4}$ state, therefore soluble manganese indicates the presence of $\mathrm{Mn}^{+2}$ (higher valences are also soluble but are not expected to be present during the SRAT cycle). The solubility of $\mathrm{Mn}^{+2}$ is $\mathrm{pH}$ dependent, therefore insoluble manganese does not necessarily represent $\mathrm{Mn}^{+4}$. As shown in Table 9, the higher acid stoichiometries resulted in all the manganese being soluble. Nickel solubility was also shown to be strongly dependent on the $\mathrm{pH}$. 
Table 9. Manganese and Nickel Solubility in SRAT Product

\begin{tabular}{||c|c|c|c||}
\hline \hline ACID STOICHIOMETRY & pH & MANGANESE & NICKEL \\
\hline$\%$ & & $\%$ soluble & $\%$ soluble \\
\hline 130 & 8.17 & 22.6 & 0.0 \\
\hline 150 & 6.83 & 81.0 & 1.1 \\
\hline 160 & 5.27 & 105.2 & 28.7 \\
\hline 170 & 4.78 & 108.3 & 45.3 \\
\hline
\end{tabular}

\subsubsection{Condensates}

The sample results for all condensate samples are tabulated in Appendix A along with corresponding charts in Appendix B. The major species noted in the condensate were nitrate, formate, and silicon. The nitrate and formate were most likely present as acid since no major cation species were detected. General trends indicate increased concentrations of species in the condensate as acid stoichiometry is increased. The higher amounts of formate and nitrate are expected as higher acid additions lead to higher levels of these species in the vessel. The silicon in the condensate has been shown to be the result of antifoam degradation ${ }^{18}$. Higher acid stoichiometry lowers the $\mathrm{pH}$ of the SRAT slurry and increases the rate of antifoam degradation.

Condensate $\mathrm{pH}$ was generally lower as acid stoichiometry was increased, as shown in Figure 8. The condensate $\mathrm{pH}$ of the $130 \%$ run was basic at the end of the SRAT cycle as indicated by the $\mathrm{pH}$ of the MWWT results. The MWWT was drained at the end of the SRAT cycle and (generally) represents the last condensate generated during that cycle. The nitrate results for the SRAT dewater during SB4-62 (150\% acid) are most likely in error, but the sample was not reanalyzed.
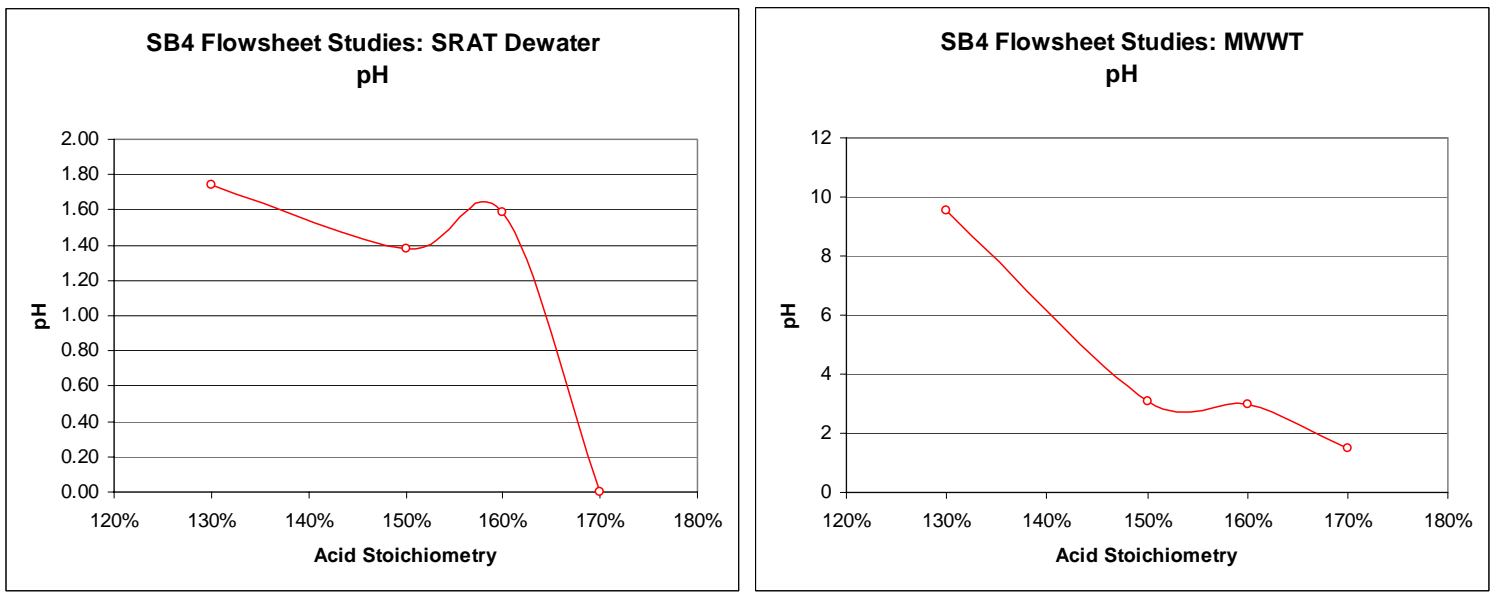

Figure 8. SRAT Dewater and MWWT pH

SVOA analysis was performed on an aggregate sample of the condensate from each run. The aggregate sample was a weighted mixture of all condensates from the SRAT and SME cycles. Past tests had indicated the presence of methyl-mercuric chlorides, but all samples from this testing were below detection limits for these species. 


\subsubsection{SRAT Cycle Offgas Composition Results}

A typical offgas concentration profile is shown in Figure 9 while charts from all runs are shown in Appendix C. Note that Figure 9 also shows the SME cycle, which started at a run time of approximately 1000 minutes. Helium and nitrogen show reduced concentrations during periods with large quantities of offgas generation due to dilution while oxygen showed reduced concentrations during these periods due to dilution and from consumption. In general, hydrogen generation began after nitrous oxide emissions had ceased and carbon dioxide emission was noted in conjunction with the hydrogen. The patterns of offgas emissions noted during the runs were typical of offgas generation during the SRAT cycle.

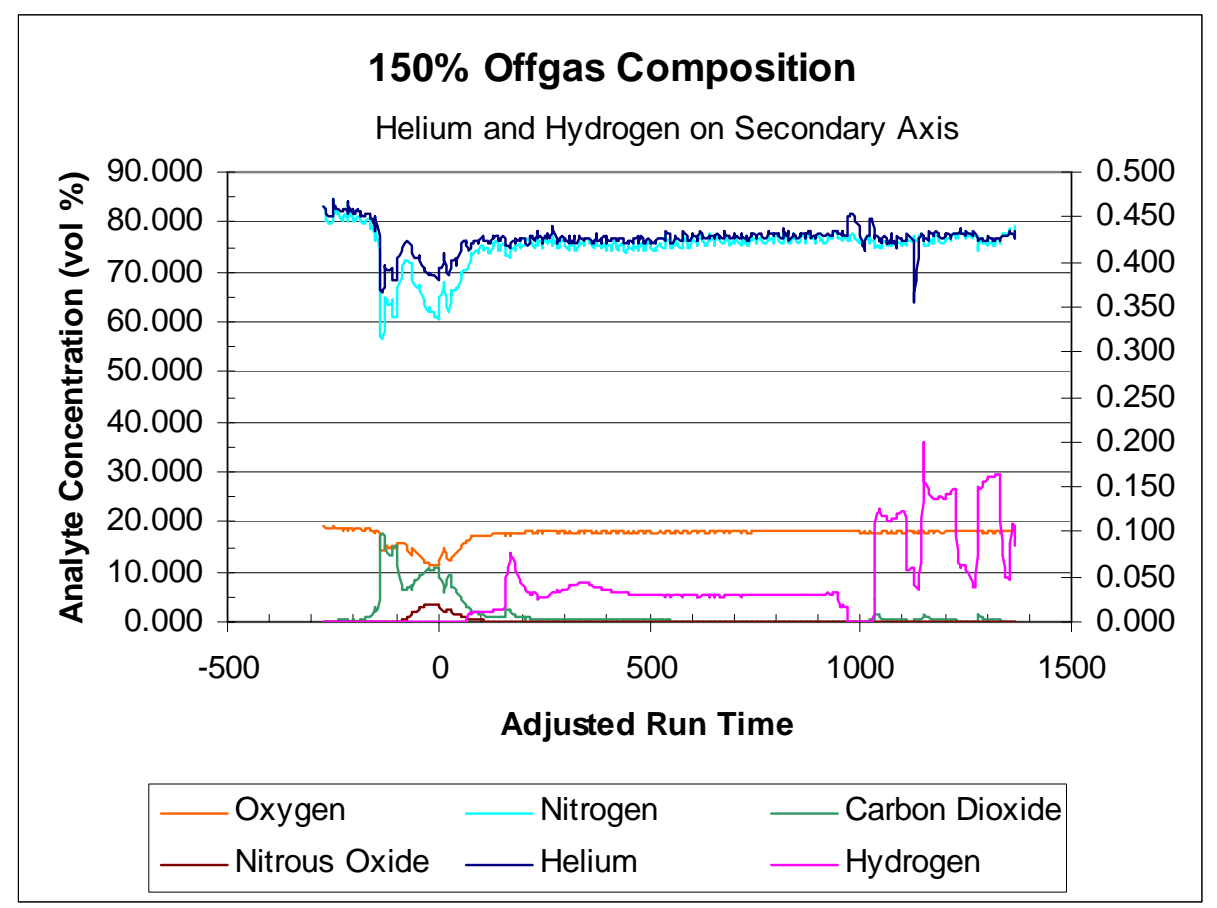

Figure 9. Offgas Data from SB4-62 (150\% Acid Stoichiometry)

\subsubsection{Hydrogen Evolution}

The peak hydrogen generation for each run is shown in Figure 10, along with the peak carbon dioxide and nitrous oxide rates. In general, the peak hydrogen generation rate increased with increased acid addition. None of the rates approached the SRAT processing limits of $0.65 \mathrm{lb} / \mathrm{hr}$, as shown in Table 10 which shows the peak hydrogen generation after scaling to the DWPF process. A review of the run data for SB4-64 (170\% acid) and SB4-63 (160\% acid) was conducted. No process upsets or issues with the acid addition and/or noble metals addition was noted which would explain the lower hydrogen emission from run SB4-64 than SB4-63. 
WSRC-STI-2006-00109

Revision 0

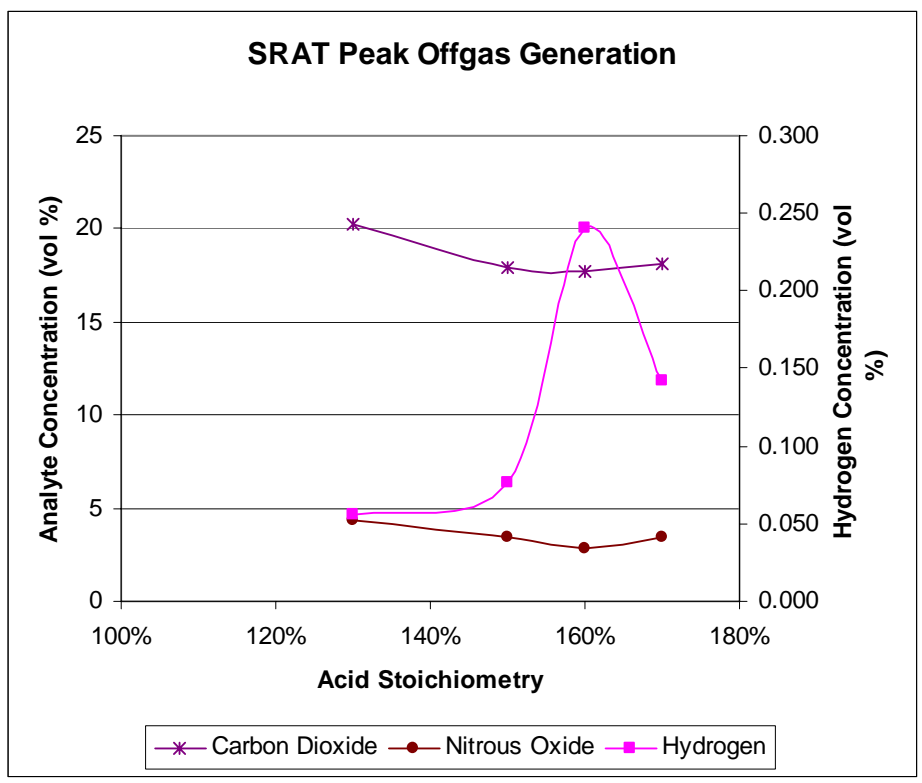

Figure 10. SRAT Cycle Peak Offgas Concentrations

Table 10. SRAT Cycle Hydrogen Peak Generation Rate

\begin{tabular}{||l|c|c|c|c|c||}
\hline \multicolumn{2}{|c|}{} & \multicolumn{4}{|c|}{ Acid Stoichiometry } \\
\cline { 3 - 6 } & $\mathbf{1 3 0 \%}$ & $\mathbf{1 5 0 \%}$ & $\mathbf{1 6 0 \%}$ & $\mathbf{1 7 0 \%}$ \\
\hline SRAT Hydrogen Peak & $\mathrm{lb} / \mathrm{hr}$ & 0.045 & 0.070 & 0.167 & 0.117 \\
\hline
\end{tabular}

The hydrogen evolution as a function of time is shown in Figure 11. Note that the SME cycle is also shown for comparison. Increased acid stoichiometry decreased the time between the start of boiling and the onset of hydrogen emission.

Hydrogen emission was only noted for the $130 \%$ acid run during acid addition. Hydrogen emission is generally not noted during this time period and may have been the result of a stagnant area in the vessel. The SRAT product initially thickens as acid is added, then thins as the $\mathrm{pH}$ drops below 6. A stagnant area could result in higher acid concentrations in the portion of the vessel that is being mixed or localized areas that are superheated in the portion that is stagnant. 


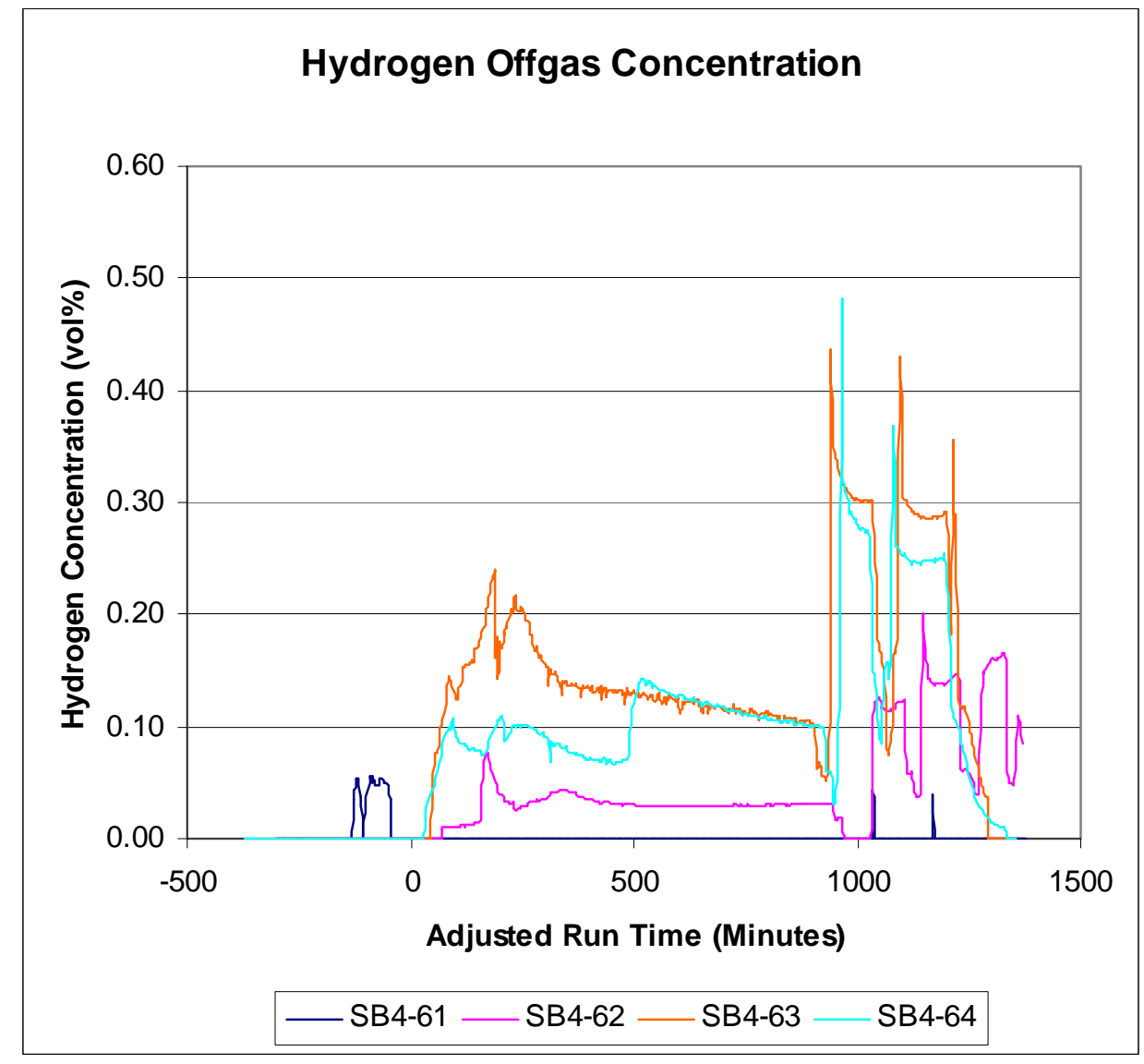

Figure 11. SRAT Cycle Hydrogen Evolution

\subsubsection{Other Species}

As shown above in Figure 10, carbon dioxide and nitrous oxide peak concentrations may have slightly decreased as acid addition was increased. The peak generation of these species is less dependent on acid concentration than hydrogen since the compounds that are responsible for the highest emissions are already present in the sludge as carbonate and nitrite. The peak generation rates are shown in Table 11 after scaling to the DWPF process scale.

Table 11. SRAT Cycle Nitrous Oxide and Carbon Dioxide Peak Generation Rates

\begin{tabular}{||l|c|c|c|c|c||}
\hline \multicolumn{2}{|c|}{} & \multicolumn{5}{|c||}{ Acid Stoichiometry } \\
\cline { 3 - 6 } & & $\mathbf{1 3 0 \%}$ & $\mathbf{1 5 0 \%}$ & $\mathbf{1 6 0 \%}$ & $\mathbf{1 7 0 \%}$ \\
\hline SRAT Nitrous Oxide Peak & $\mathrm{lb} / \mathrm{hr}$ & 27.0 & 27.3 & 17.0 & 25.3 \\
\hline SRAT Carbon Dioxide Peak & $\mathrm{lb} / \mathrm{hr}$ & 134.9 & 149.5 & 116.3 & 143.9 \\
\hline
\end{tabular}

\subsubsection{SRAT Product Rheological Properties}

The rheological properties of SRAT products were outside the processing limits for yield stress and consistency for SRAT products (yield stress 1.5 to $5 \mathrm{~Pa}$ and Consistency 5 to $12 \mathrm{cP}$ ) ${ }^{\mathrm{d}}$ except

\footnotetext{
d “Technical Data Summary for the Defense Waste Processing Facility: Sludge Plant”, DPSTD-80-38-2
} 
for the $150 \%$ acid run. The yield stress of the $130 \%$ run was higher than the upper limit for yield stress while the $160 \%$ and $170 \%$ runs were below the minimum yield stress. The yield stress and consistency of the SRAT products are shown in Table 12. The flow curve shape varied considerably, but the overall trend can be seen in the data that runs with higher acid additions were less viscous. All SRAT cycles targeted $25 \mathrm{wt} \%$ solids and the measured results indicate very little variability in the total solids between runs, so the difference in rheological behavior results from the different acid stoichiometries and corresponding soluble species. The flow curves generated during the testing are shown in Appendix D.

Table 12. Rheological Properties of SRAT Products

\begin{tabular}{||c|c|c|c|c||}
\hline & \multicolumn{2}{|c|}{ Up Curve } & \multicolumn{2}{c||}{ Down Curve } \\
\hline & $\begin{array}{c}\text { Yield } \\
\text { Stress }\end{array}$ & Consistency & $\begin{array}{c}\text { Yield } \\
\text { Stress }\end{array}$ & Consistency \\
\hline & $\mathrm{Pa}$ & $\mathrm{cP}$ & $\mathrm{Pa}$ & $\mathrm{cP}$ \\
\hline SB4-61-1 & 10.07 & 10.82 & 10.80 & 7.18 \\
\hline SB4-61-2 & 11.90 & 5.95 & 9.62 & 7.16 \\
\hline $\mathbf{1 3 0 \%}$ Ave & $\mathbf{1 0 . 9 9}$ & $\mathbf{8 . 3 8}$ & $\mathbf{1 0 . 2 1}$ & $\mathbf{7 . 1 7}$ \\
\hline & & & & \\
\hline SB4-62-1 & 3.15 & 8.93 & 1.85 & 10.94 \\
\hline SB4-62-2 & 3.42 & 8.61 & 1.91 & 11.04 \\
\hline $\mathbf{1 5 0 \%}$ Ave & 3.29 & $\mathbf{8 . 7 7}$ & $\mathbf{1 . 8 8}$ & $\mathbf{1 0 . 9 9}$ \\
\hline & & & & \\
\hline SB4-63-1 & 1.03 & 8.05 & 0.81 & 8.09 \\
\hline SB4-63-2 & 1.01 & 7.96 & 0.83 & 8.00 \\
\hline $\mathbf{1 6 0 \%}$ Ave & $\mathbf{1 . 0 2}$ & $\mathbf{8 . 0 1}$ & $\mathbf{0 . 8 2}$ & $\mathbf{8 . 0 4}$ \\
\hline & & & & \\
\hline SB4-64-1 & 0.69 & 7.47 & 0.52 & 7.42 \\
\hline SB4-64-2 & 0.73 & 7.48 & 0.55 & 7.49 \\
\hline $\mathbf{1 7 0 \% ~ A v e ~}$ & $\mathbf{0 . 7 1}$ & $\mathbf{7 . 4 8}$ & $\mathbf{0 . 5 4}$ & $\mathbf{7 . 4 5}$ \\
\hline
\end{tabular}

The shape of the flow curves is expected to be that of a Bingham Plastic, but the more viscous SRAT products (130 and 150\% runs) had flow curves that contained humps. This type of flow curve has been noted during previous testing and has been evaluated previously ${ }^{19}$. The yield stress and consistency of the down curve is considered to be more representative when flow curves are shaped in the manner of the curves for the $130 \%$ and $150 \%$ acid run.

As shown in Figure 12, the impact of increased acid addition diminished as acid was increased over 160\%. The diminished impact may be the result of the behavior of manganese and other soluble species. At 160\%, acid manganese was 100\% soluble. Increasing the acid stoichiometry to $170 \%$ did dissolve some of the nickel, but the impact of nickel solubility would be less then the impact of manganese due to the smaller amount of nickel in the slurry. 
WSRC-STI-2006-00109

Revision 0

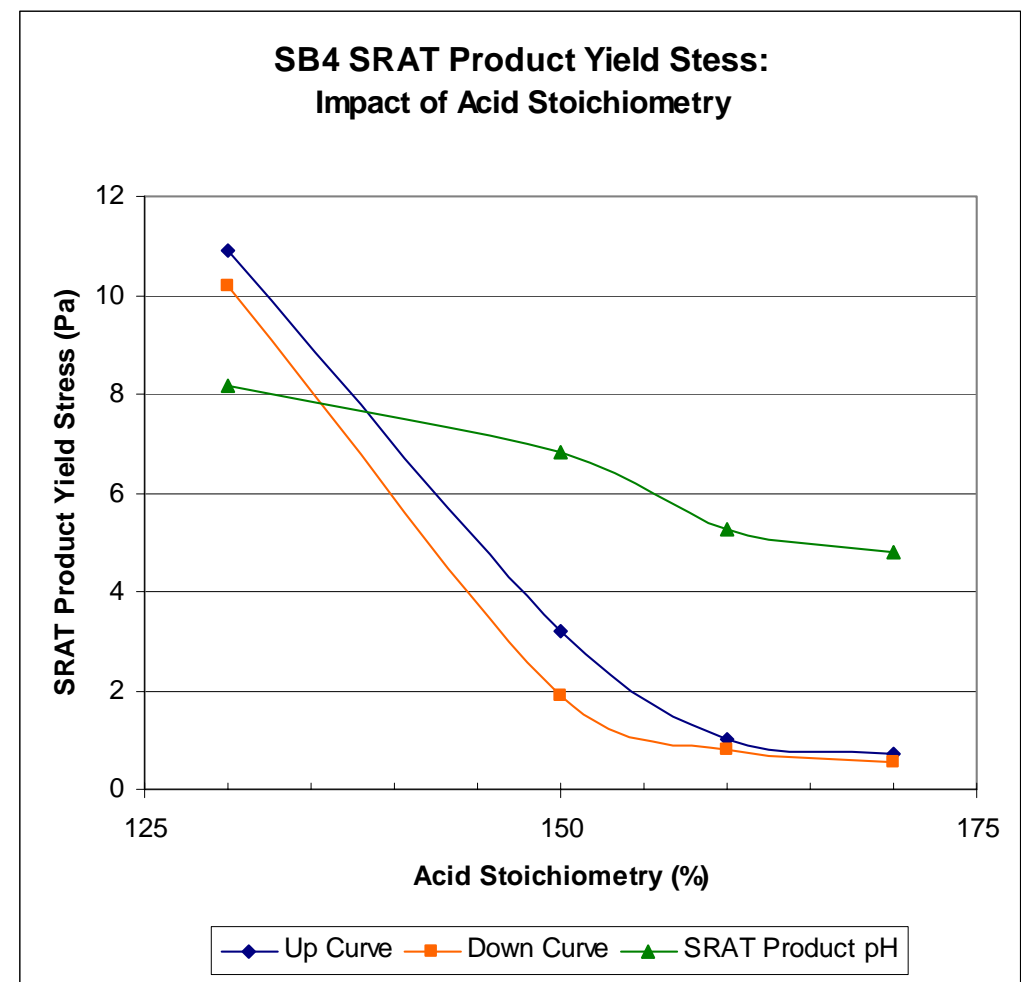

Figure 12. Impact of Acid Stoichiometry on SRAT Product Yield Stress

\subsection{SME Cycle Results}

The SME cycle was performed immediately following the SRAT cycle and utilized the estimated amount of frit based on the initial sludge additions and the expected amount of SRAT samples. As stated earlier, the SME cycle targeted a final solids concentration of $45 \mathrm{wt} \%$ total solids based on earlier testing using the same simulants that resulted in extremely viscous slurries at the end of the SME cycle ${ }^{20}$.

\subsubsection{Processing Observations}

No processing issues were noted during the SME cycle. Mixer speed was maintained at 250 RPM throughout each run except for the $130 \%$ run. Agitator speed was increased to 320 RPM during this run to maintain mixing, which is similar to the conditions at the start of the SRAT cycle.

As shown in Figure 2 above, the $\mathrm{pH}$ profile of each SME cycle followed a similar profile with a dip in $\mathrm{pH}$ as the frit is added due to the formic acid content of the frit slurry followed by a gradual rise in $\mathrm{pH}$ as the slurry mix is evaporated.

\subsubsection{SME Cycle Sample Results}

Samples were pulled at the conclusion of the SME cycle and analyzed for total solids, anions, soluble elemental species, mercury, and REDOX. Samples were taken of the SME dewater and the FAVC contents at the completion of the SME cycle. All sample results are tabulated in Appendix A while graphical presentations are shown in Appendix B. 


\subsubsection{SME Product Results}

The solids content of the SME products are shown in Table 13 along with the calculated waste loading and $\mathrm{pH}$. The solids content generally were $\sim 2 \mathrm{wt} \%$ higher than targeted, but the waste loading targets were generally very close to the $35 \%$ target as calculated from the lithium content of the SME product. Mercury continued to be steam stripped from the process slurry and final levels of mercury were reduced slightly compared to the SRAT products.

Table 13. SME Product Results

\begin{tabular}{||c|c|c|c|c||}
\hline \hline RUN ID & PH & $\begin{array}{c}\text { TOTAL } \\
\text { SOLIDS }\end{array}$ & $\begin{array}{c}\text { LITHIUM OXIDE } \\
\text { CONTENT }\end{array}$ & $\begin{array}{c}\text { WASTE } \\
\text { LOADING }\end{array}$ \\
\hline & & $\mathrm{wt} \%$ & $\mathrm{wt} \%$ Calcined solids & wt \% \\
\hline $130 \%$ & 7.43 & 46.65 & 5.17 & 35.4 \\
\hline $150 \%$ & 6.98 & 47.57 & 5.22 & 34.7 \\
\hline $160 \%$ & 5.72 & 46.83 & 5.15 & 35.6 \\
\hline $170 \%$ & 5.35 & 47.13 & 5.06 & 36.7 \\
\hline
\end{tabular}

Loss of formate was noted during the SME cycle, as shown in Figure 13 and Table 14. The values noted during the testing are similar to results from previous runs ${ }^{4}$ and are relatively uniform from run to run. The amount of nitrate loss was small for all runs, with the highest acid stoichiometry indicating a loss of $8.5 \%$. The negative values for the lower acid stoichiometries likely result from the expected analytical error and cumulative errors in the mass balance as various samples are pulled.

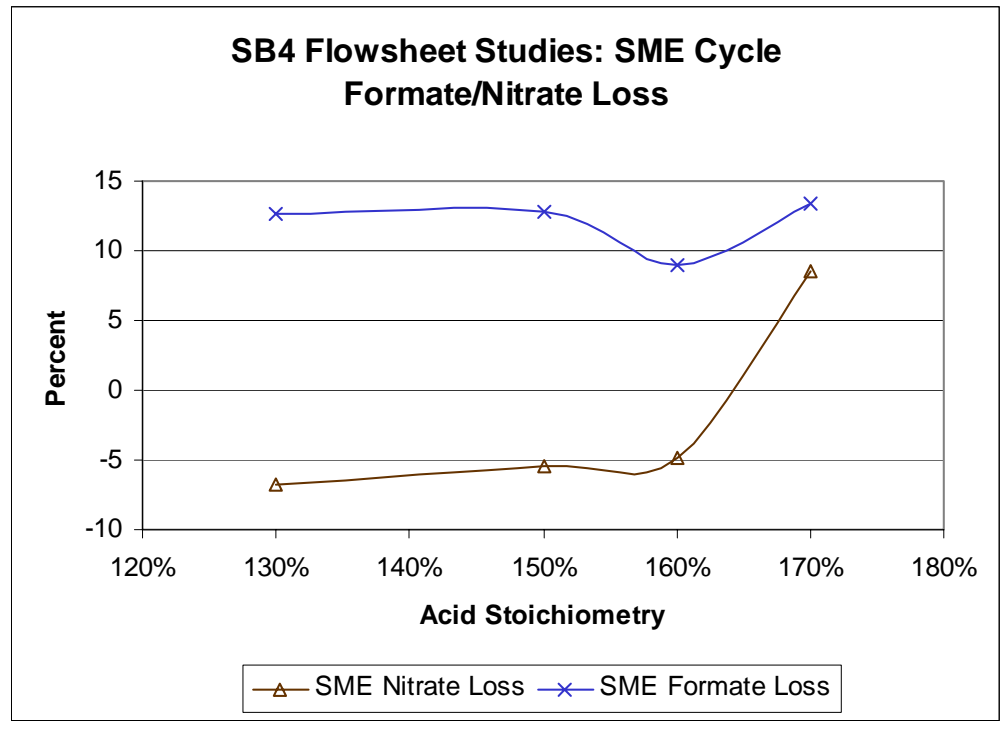

Figure 13. SME Cycle Formate / Nitrate Loss

Table 14. SME Cycle Formate / Nitrate Loss

\begin{tabular}{||l|c|c|c|c|c||}
\hline & & $\mathbf{1 3 0} \%$ & $\mathbf{1 5 0} \%$ & $\mathbf{1 6 0} \%$ & $\mathbf{1 7 0 \%}$ \\
\hline Nitrate Lost & $\%$ & -6.83 & -5.41 & -4.92 & 8.58 \\
\hline Formate Lost & $\%$ & 12.65 & 12.77 & 8.98 & 13.42 \\
\hline
\end{tabular}




\subsubsection{Condensates}

The condensate from SME dewater followed the same trends as the SRAT cycle condensate. $\mathrm{pH}$ was generally higher than the SRAT dewater and the SRAT MWWT. The $\mathrm{pH}$ was higher during runs with the lowest acid addition, as shown in Figure 14. As with the SRAT condensate, the major species present were formate and silicon, but nitrate was not noted. The dominant species in the FAVC was nitrate with silicon as the major cation.

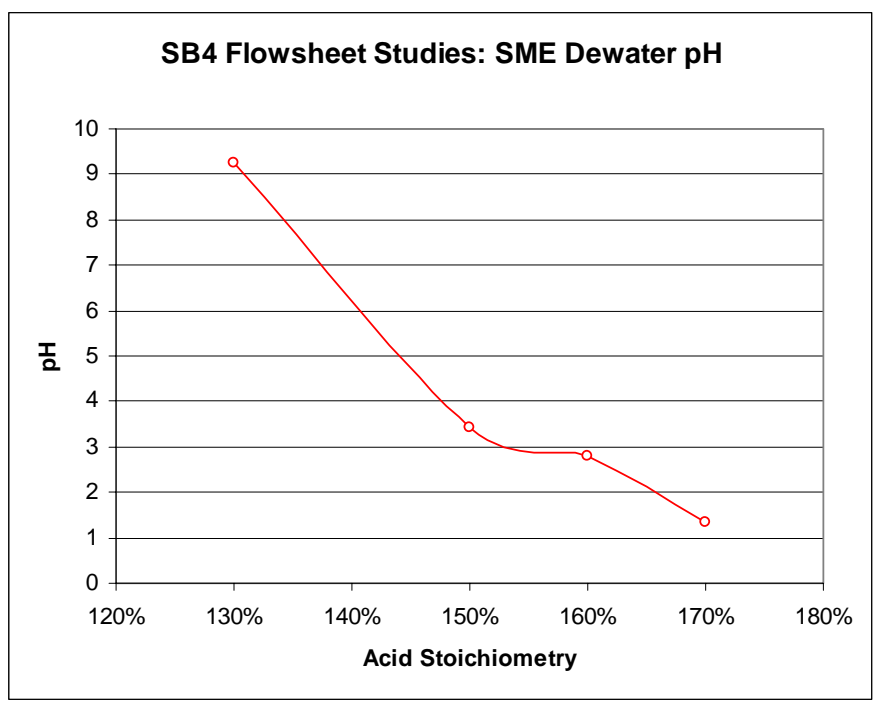

Figure 14. SME Dewater pH

\subsubsection{SME Cycle Offgas Composition Results}

The amount of offgas generated during the runs generally increased as acid stoichiometry increased, as indicated by the helium concentration in the offgas since helium is added at a constant $0.5 \mathrm{wt} \%$ of the incoming air purge. A typical offgas concentration profile is shown in Figure 15 (the SME cycle starts at $\sim 1000$ minutes) while charts from all runs are shown in Appendix C. The patterns of offgas emissions noted during the runs were typical of offgas generation during the SME cycle with hydrogen and carbon dioxide emissions occurring during dewatering after each frit addition. 


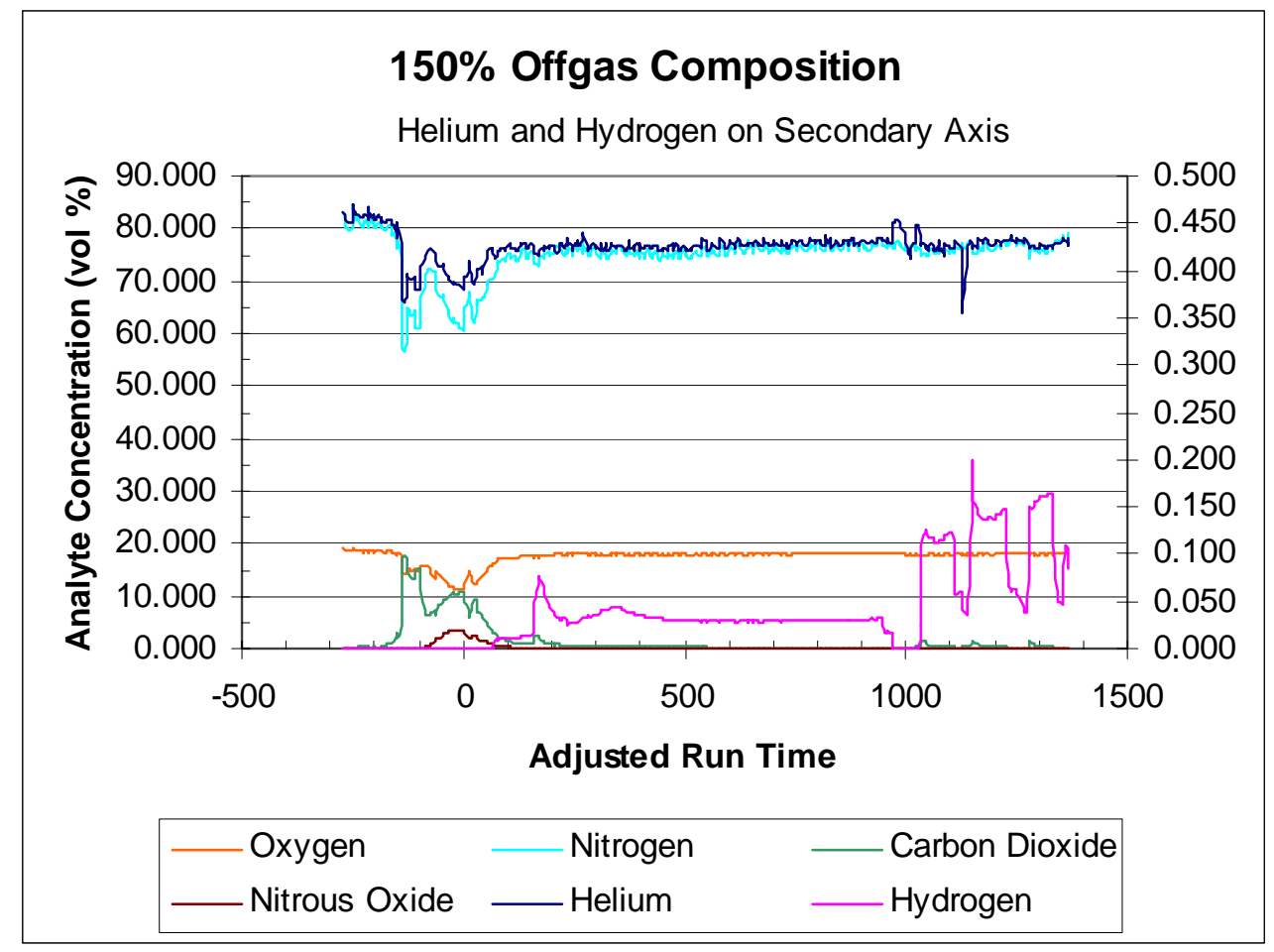

Figure 15. Typical Offgas Profile

\subsubsection{Hydrogen Evolution}

The peak hydrogen generation rates were generally noted as sharp spikes in the data immediately following the start of dewater, as shown in Figure 11 above. Hydrogen reached concentrations higher than noted in the SRAT cycle due to the decreased purge during the SME cycle. Peak hydrogen concentrations reached close to 0.5 volume \%, as shown in Figure 16 and were a function of acid stoichiometry. Peak generation rates scaled to the DWPF process are shown in Table 15 and were all below the SME process limit of $0.223 \mathrm{lb} / \mathrm{hr}$.

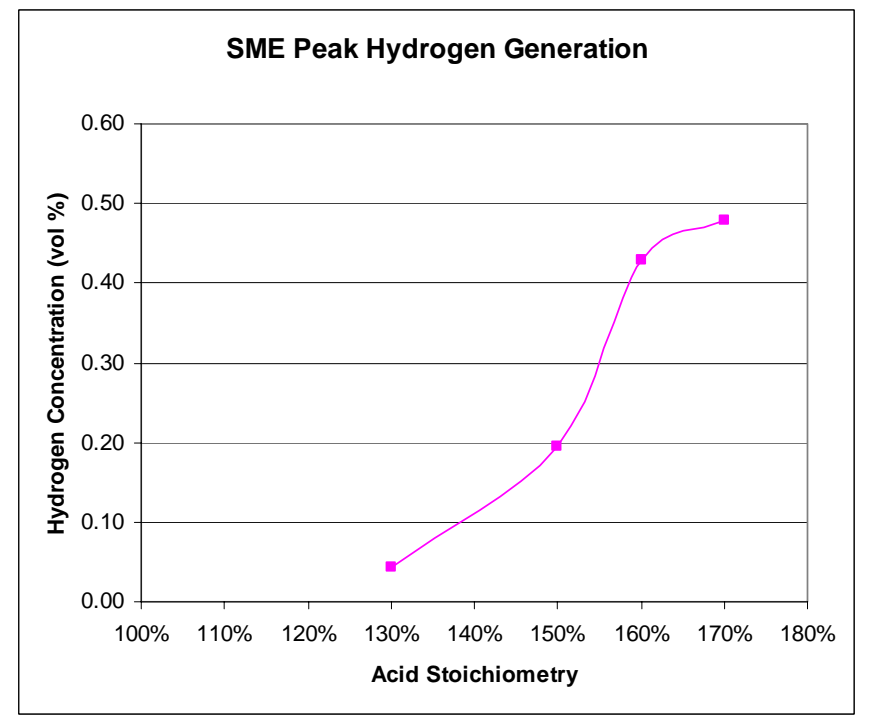

Figure 16. Peak Hydrogen Generation during SME Cycle 
WSRC-STI-2006-00109

Revision 0

Table 15. SME Cycle Hydrogen Peak Generation Rates

\begin{tabular}{||l|c|c|c|c|c||}
\hline \multicolumn{2}{|c|}{} & \multicolumn{4}{|c|}{ Acid Stoichiometry } \\
\cline { 3 - 6 } & & $\mathbf{1 3 0 \%}$ & $\mathbf{1 5 0 \%}$ & $\mathbf{1 6 0 \%}$ & $\mathbf{1 7 0 \%}$ \\
\hline SME Hydrogen Peak & $\mathrm{lb} / \mathrm{hr}$ & 0.009 & 0.050 & 0.089 & 0.121 \\
\hline
\end{tabular}

\subsubsection{Other Species}

Carbon dioxide was generally the only other gas of any significance emitted during the SME cycle (the $130 \%$ acid run contained a small amount of nitrous oxide emissions from the nitrite remaining after the SRAT cycle). Peak carbon dioxide generation is shown in Figure 17.

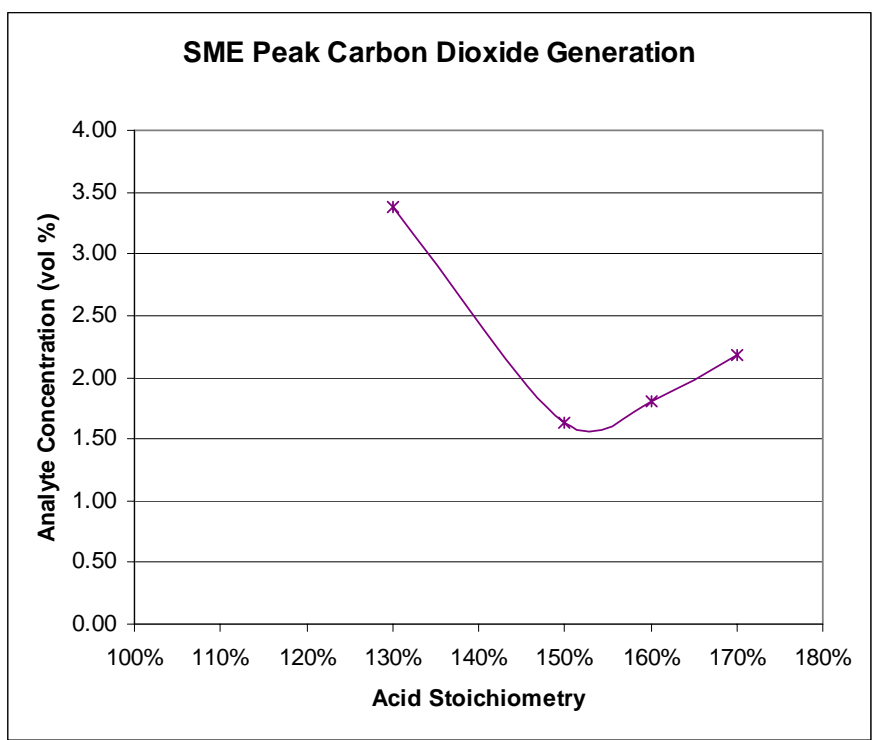

Figure 17. SME Cycle Carbon Dioxide Peak Generation Rates

Table 16. SME Cycle Carbon Dioxide and Nitrous Oxide Peak Generation Rates

\begin{tabular}{||l|c|c|c|c|c||}
\hline \multicolumn{2}{|c|}{} & \multicolumn{4}{|c|}{ Acid Stoichiometry } \\
\cline { 3 - 6 } & & $\mathbf{1 3 0 \%}$ & $\mathbf{1 5 0 \%}$ & $\mathbf{1 6 0 \%}$ & $\mathbf{1 7 0 \%}$ \\
\hline SME Nitrous Oxide Peak & $1 \mathrm{~b} / \mathrm{hr}$ & 0.141 & 0.00 & 0.00 & 0.00 \\
\hline SME Carbon Dioxide Peak & $1 \mathrm{~b} / \mathrm{hr}$ & 5.32 & 3.34 & 3.01 & 4.41 \\
\hline
\end{tabular}

\subsubsection{SME Product Rheological Properties}

The rheological properties of each SME product were measured as well as the rheological properties of the $150 \%$ acid run at different solids concentrations. Four $250 \mathrm{ml}$ samples of the SME product were pulled and centrifuged at 1000 RPM for 10 minutes in an IEC Centra GP8 centrifuge. After centrifuging, supernate was decanted or added to reach the solids concentration target. The highest targeted solids concentration (52\%) could not be reached as the supernate layer was not sufficient to remove the targeted amount. Solids content of each sample was measured to verify the total solids in each sample were correct. 
Higher acid stoichiometry lowered the yield stress and consistency of the SME products, as shown in Figure 18. The $130 \%$ acid run exceeded the upper process limit for yield stress $(15 \mathrm{~Pa})^{\mathrm{e}}$. All runs met the process limits for consistency $(10$ to $40 \mathrm{cP})$ and the lower limit for yield stress (2.5 Pa), as shown in Table 17. The $150 \%$ acid run yield stress and consistency increased sharply as solids content was increased, as shown in Figure 19. This result is consistent with previous results. Previous testing with sludge simulants has indicated that centrifuging and resuspending the solids can impact the yield stress ${ }^{21}$. The baseline sample during the solids study was repeated to evaluate the impact of the centrifuging process. The baseline sample yield stress was increased slightly by centrifuging, as shown in Table 18 .

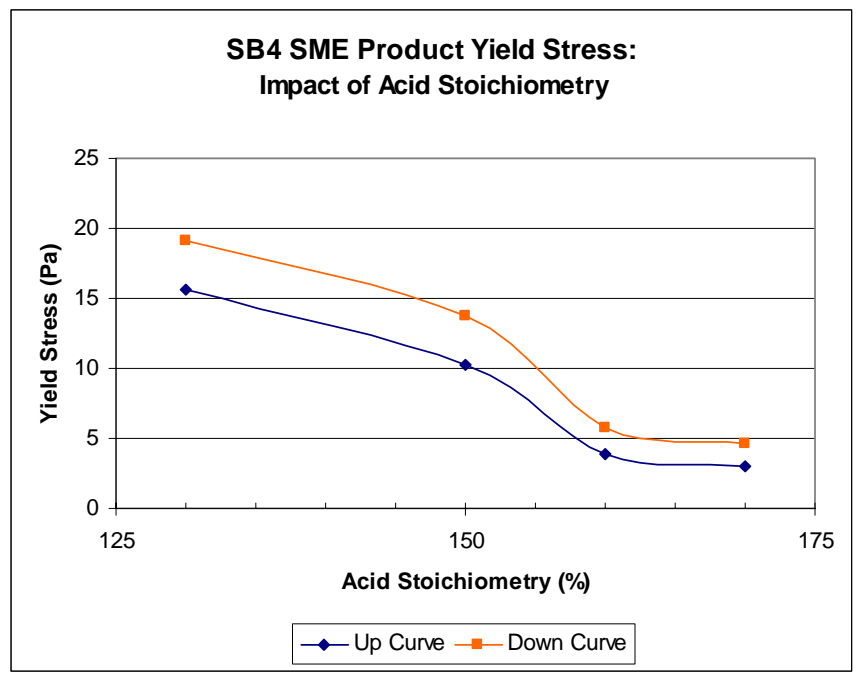

Figure 18. SME Product Yield Stress

Table 17. SME Product Rheological Properties

\begin{tabular}{|c|c|c|c|c|}
\hline & \multicolumn{2}{|c|}{ Up Curve } & \multicolumn{2}{|c|}{ Down Curve } \\
\hline & Yield Stress & Consistency & Yield Stress & Consistency \\
\hline & $\mathrm{Pa}$ & $\mathrm{cP}$ & $\mathrm{Pa}$ & $\mathrm{cP}$ \\
\hline SB4-61-1 & 15.88 & 21.79 & 19.34 & 20.62 \\
\hline SB4-61-2 & 15.50 & 23.06 & 18.99 & 21.97 \\
\hline $130 \%$ Ave & 15.69 & 22.43 & 19.16 & 21.29 \\
\hline SB4-62-1 & 10.41 & 24.18 & 14.09 & 20.31 \\
\hline SB4-62-2 & 10.09 & 25.22 & 13.40 & 23.00 \\
\hline $150 \%$ Ave & 10.25 & 24.70 & 13.74 & 21.66 \\
\hline SB4-63-1 & 3.92 & 19.67 & 5.63 & 17.88 \\
\hline SB4-63-2 & 3.87 & 20.13 & 5.89 & 16.67 \\
\hline $160 \%$ Ave & 3.89 & 19.90 & 5.76 & 17.28 \\
\hline SB4-64-1 & 3.04 & 17.80 & 4.55 & 18.17 \\
\hline SB4-64-2 & 3.07 & 7.93 & 4.58 & 18.22 \\
\hline 170\% Ave & 3.06 & 12.87 & 4.57 & 18.19 \\
\hline
\end{tabular}

\footnotetext{
e “Technical Data Summary for the Defense Waste Processing Facility: Sludge Plant”, DPSTD-80-38-2
} 


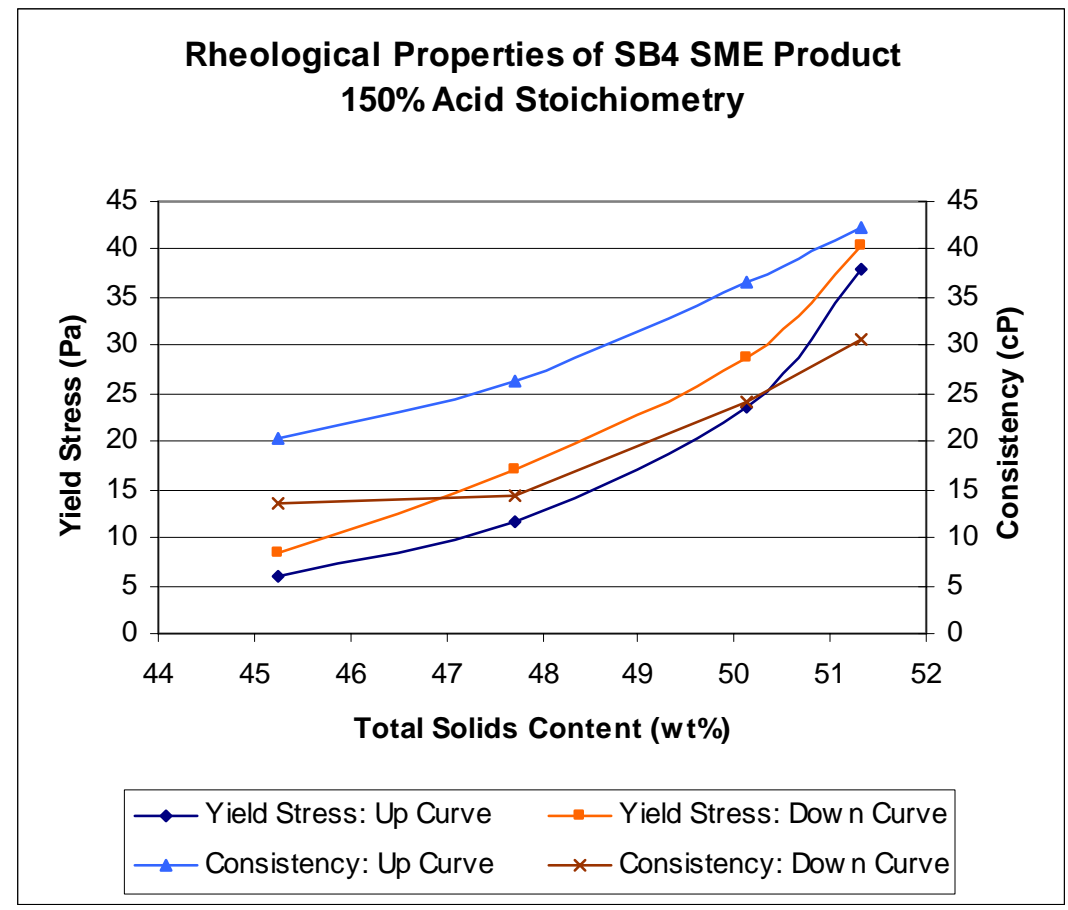

Figure 19. 150\% Acid Rheological Properties versus Solids Content

Table 18. SME Product Rheology versus Solids Content

\begin{tabular}{||c|c|c|c|c||}
\hline Total & \multicolumn{2}{|c|}{ Up } & \multicolumn{2}{c||}{ Down } \\
\hline Solids & Yield Stress & Consistency & Yield Stress & Consistency \\
\hline wt\% & Pa & cP & Pa & cP \\
\hline 45.26 & 6.01 & 20.27 & 8.44 & 13.59 \\
\hline 47.72 (prior to centrifuge) & 10.25 & 24.70 & 13.74 & 21.66 \\
\hline 47.72 & 11.66 & 26.34 & 17.07 & 14.48 \\
\hline 50.14 & 23.57 & 36.52 & 28.79 & 24.07 \\
\hline 51.33 & 37.88 & 42.21 & 40.35 & 30.58 \\
\hline
\end{tabular}

\subsubsection{REDOX Results}

Previous testing with SB4 simulants has indicated that the Reduction-oxidization (REDOX) potential of the glass ${ }^{\mathrm{f}}$ has been more oxidizing than predicted ${ }^{22}$. Evaluation of the discrepancies between the predicted and measured REDOX values has focused on the role of manganese in the melter REDOX. The current equation for prediction of glass REDOX assumes that manganese must be converted from the $\mathrm{Mn}^{+4}$ state to $\mathrm{Mn}^{+2}$ in the cold cap, yielding a coefficient of " 2 " for manganese based on the number of electrons transferred. Assuming a coefficient of "5" in the prediction equation yields results closer to the measured values and has been used for this testing. A coefficient of " 5 " would result if the manganese was in the $\mathrm{Mn}^{+7}$ state in the melter feed or converted to $\mathrm{Mn}^{+7}$ in the cold cap.

\footnotetext{
${ }^{\mathrm{f}} \mathrm{REDOX}$ is measured by determining the ratio of $\mathrm{Fe}^{+2}$ to total $\mathrm{Fe}$ in the glass. A REDOX target of 0.2 $\mathrm{Fe}^{+2} / \Sigma \mathrm{FE}$ was utilized for this testing assuming $\mathrm{Mn}^{+7}$ in the melter feed.
} 
The predicted REDOX values shown in Table 19 are based on the sample results of the SME product. Measured values are the average of duplicate samples generated by the guidelines of L29 ITS-0052 "Vitrification of Melter Slurries for Glass Redox (Fe2+/ Fe) \& Chemical Composition Measurement"23.

Table 19. SME Product REDOX

\begin{tabular}{|c|c|c|c|c|}
\hline $\begin{array}{l}\text { Calculation } \\
\text { Inputs }\end{array}$ & SB4-61 & SB4-62 & SB4-63 & SB4-64 \\
\hline Nitrite $(\mathrm{mg} / \mathrm{kg})$ & 101.5 & 0 & 0 & 0 \\
\hline Nitrate $(\mathrm{mg} / \mathrm{kg})$ & 20200 & 22550 & 24950 & 23000 \\
\hline Formate $(\mathrm{mg} / \mathrm{kg})$ & 51110 & 55500 & 57450 & 58600 \\
\hline Oxalate (mg/kg) & 130 & 0 & 0 & 0 \\
\hline $\mathrm{Mn}(\mathrm{wt} \%$ calcine $)$ & 1.46 & 1.47 & 1.48 & 1.52 \\
\hline $\mathrm{Wt} \%$ Solids & 46.65 & 47.57 & 46.83 & 47.13 \\
\hline Calcine Solids & 38.81 & 39.11 & 38.31 & 38.16 \\
\hline Nitrite $(\mathrm{mol} / \mathrm{kg})$ & 0.0022 & 0.0000 & 0.0000 & 0.0000 \\
\hline Nitrate $(\mathrm{mol} / \mathrm{kg})$ & 0.3258 & 0.3637 & 0.4024 & 0.3710 \\
\hline Formate $(\mathrm{mol} / \mathrm{kg})$ & 1.1358 & 1.2333 & 1.2767 & 1.3022 \\
\hline Oxalate $(\mathrm{mol} / \mathrm{kg})$ & 0.0000 & 0.0000 & 0.0000 & 0.0000 \\
\hline $\mathrm{Mn}(\mathrm{mol} / \mathrm{kg})$ & 0.1031 & 0.1049 & 0.1032 & 0.1056 \\
\hline \multicolumn{5}{|l|}{$\begin{array}{l}\text { Predicted Redox } \\
\left(\mathrm{Fe}^{+2} / \Sigma \mathrm{Fe}\right)\end{array}$} \\
\hline $\mathrm{Mn}^{+7}$ & 0.216 & 0.217 & 0.199 & 0.235 \\
\hline $\mathrm{Mn}^{+4}$ & 0.273 & 0.273 & 0.256 & 0.292 \\
\hline \multicolumn{5}{|l|}{ Measured Redox } \\
\hline$\left(\mathrm{Fe}^{+2} / \Sigma \mathrm{Fe}\right)$ & 0.056 & 0.075 & 0.084 & 0.088 \\
\hline
\end{tabular}

As shown in Figure 20, the measured REDOX increased with increased acid stoichiometry, but all results are significantly less than the predicted values. The predictions are based on SME product sample results, therefore the predicted values are not biased due to assumptions made during the acid calculations.

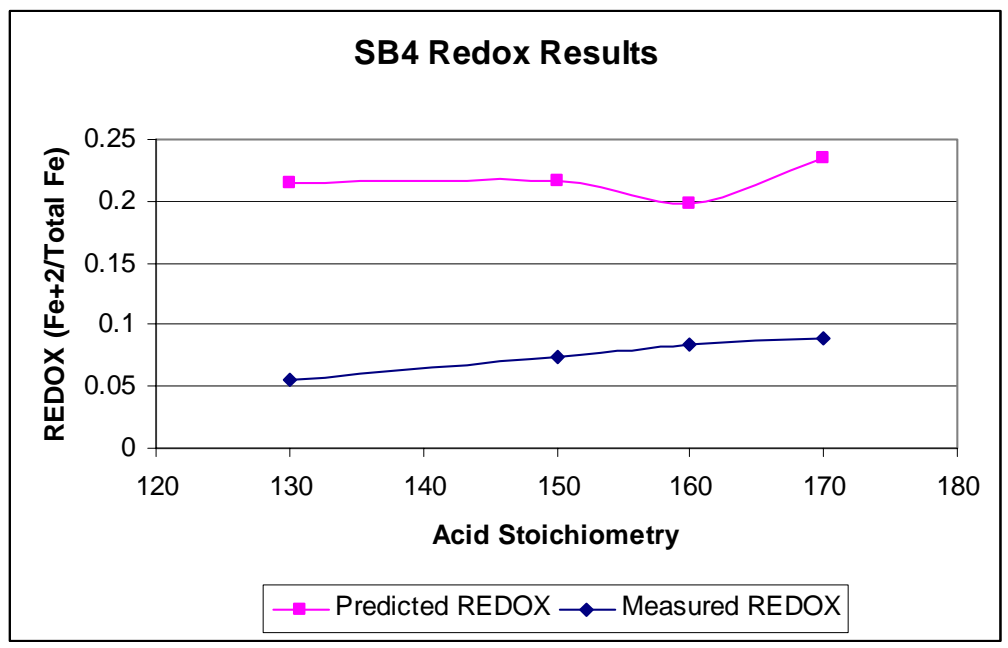

Figure 20. SB4 Flowsheet Testing REDOX Results 


\subsection{Conclusions}

No significant processing issues with processing SB4 were noted during the run.

Hydrogen and nitrous oxide generation rates as a function of acid stoichiometry

Hydrogen generation was significantly impacted by the changes in acid stoichiometry from $130 \%$ to $170 \%$ (1.39 to 1.82 mole acid per liter of sludge), but all generation rates were within process limits. Hydrogen generation and nitrous oxide generation scaled to DWPF are shown in Table 20.

Table 20. Offgas Peak Summary

\begin{tabular}{||l|c|c|c|c|c||}
\hline \hline \multicolumn{2}{|c|}{} & \multicolumn{4}{|c||}{ Acid Stoichiometry } \\
\cline { 3 - 6 } & & $\mathbf{1 3 0 \%}$ & $\mathbf{1 5 0 \%}$ & $\mathbf{1 6 0 \%}$ & $\mathbf{1 7 0 \%}$ \\
\hline SRAT Hydrogen Peak & $\mathrm{lb} / \mathrm{hr}$ & 0.045 & 0.070 & 0.167 & 0.117 \\
\hline SME Hydrogen Peak & $\mathrm{lb} / \mathrm{hr}$ & 0.009 & 0.050 & 0.089 & 0.121 \\
\hline SRAT Nitrous Oxide Peak & $\mathrm{lb} / \mathrm{hr}$ & 27.0 & 27.3 & 17.0 & 25.3 \\
\hline SME Nitrous Oxide Peak & $\mathrm{lb} / \mathrm{hr}$ & 0.141 & 0.00 & 0.00 & 0.00 \\
\hline SRAT Carbon Dioxide Peak & $\mathrm{lb} / \mathrm{hr}$ & 134.9 & 149.5 & 116.3 & 143.9 \\
\hline SME Carbon Dioxide Peak & $\mathrm{lb} / \mathrm{hr}$ & 5.32 & 3.34 & 3.01 & 4.41 \\
\hline
\end{tabular}

$>$ Acid quantities and processing times required for mercury removal

Mercury was added to the sludge simulant at the start of the SRAT cycle as mercuric oxide at 1.0 wt $\%$ (solids basis) based on the expected composition of the SB4 blend. Acid quantities from $130 \%$ to $170 \%$ resulted in satisfactory mercury removal with 12 hours of reflux boiling. Mercury accumulation was noted on the agitator shaft and impellers during the $130 \%$ acid run. This material would not be transferred to the SME cycle, therefore it does not represent failure to remove mercury. However, accumulation of deposits on processing equipment is not desirable and discussions concerning whether or not the accumulation on the impellers would continue or the mercury would slough off during subsequent processing would be highly speculative.

Acid quantities and processing times required for nitrite destruction

Acid quantities from $130 \%$ to $170 \%$ resulted in satisfactory nitrite destruction with 12 hours of reflux boiling. $130 \%$ probably represents the lower end of the window since there was still a small amount of nitrite present but was less than $1000 \mathrm{mg} / \mathrm{kg}$.

> Impact of SB4 composition (in particular, manganese, nickel, mercury, and aluminum) on DWPF processing (i.e. acid addition strategy, foaming, hydrogen generation, REDOX control, rheology, etc.)

Acid quantities from $130 \%$ to $170 \%$ resulted in satisfactory process performance with no significant issues noted. Foaming was noted during formic acid addition, but lab-scale operations did not utilize an antifoam addition between the nitric and formic acid additions. Addition of antifoam equal to the amount added at DWPF between the acid additions was sufficient to control foaming. Increased solubility of $\mathrm{Mn}$ and $\mathrm{Ni}$ were noted as acid stoichiometry increased.

Except for the $150 \%$ run, all SRAT products were outside the process limits for yield stress with the lowest acid (130\%) being above the process limit and the $160 \%$ and $170 \%$ runs being below 
WSRC-STI-2006-00109

Revision 0

the process limit. The process limits for SME product yield stress were met for the $150 \%$ acid run at $47 \%$ solids, but the $130 \%$ acid run was above process limits and the $160 \%$ and $170 \%$ runs were slightly below process limits. The $150 \%$ acid run exceeded the upper limit for SME product yield stress when concentrated to $50 \mathrm{wt} \%$ solids. It should be noted that the trend seen in rheological properties of the simulants are expected to be similar for the DWPF process slurries, but the absolute values for the simulants are not expected to be prototypical in yield stress or consistency. Adjustment in the solids concentration targets and/or acid stoichiometry should be made if processing problems due to viscous process slurries are noted in DWPF.

The $\mathrm{pH}$ of the condensate generated was typically acidic, but the $130 \%$ acid run resulted in condensate that was basic before the end of the SRAT cycle and throughout the SME cycle with a $\mathrm{pH}$ of approximately 9. All condensates from all other runs had a $\mathrm{pH}$ of less than 4 .

Measured REDOX values for all runs were significantly below the predicted values. REDOX values increased slightly as acid stoichiometry was increased. The issues with REDOX using SB4 simulants have been evaluated in a separate study and will be documented in a separate report. 


\subsection{Recommendations}

Based on this series of runs, an acid stoichiometry of $150 \%$ is recommended for initial SB4 processing with an acid window of $130 \%$ to $170 \%$. The SB4 simulant used during the testing had a stoichiometric acid requirement of $1.07 \mathrm{~mol} / \mathrm{L}$, giving an acid addition of $1.60 \mathrm{~mol} / \mathrm{L}$ at $150 \%$ acid. The actual DWPF recommendation will be finalized once processing studies are completed with the blended sample.

The manganese term in the electron equivalence REDOX model should be changed from a coefficient of " 2 " to a coefficient of " 5 " for SB4 processing. Additional studies are needed to determine the cause of the lower than predicted REDOX values in this program.

No changes to the DWPF antifoam addition strategy, acid addition rate, reflux time, or SME solids targets are recommended. 


\subsection{References}

1 Fellinger, T. L., Sludge Batch 4 Flowsheet Studies. HLW/DWPF/TTR-04-0031 Revision 1, Savannah River Site, Aiken, SC 29808 (2006).

2 Lambert, D. P., Task Technical \& QA Plan: Sludge Batch 4 Simulant Flowsheet Studies with MCU and ARP, WSRC-RP-2004-00881 Revision 1, Savannah River Site, Aiken, SC 29808 (2006).

3 Baich, M.A., C.C. Herman, D.R. Best, M.F. Williams, and E.K. Hansen, Sludge Batch 4 Initial Simulant Flowsheet Studies: Phase I SRAT Results, WSRC-TR-2005-00194, Savannah River Site, Aiken, SC 29808 (2005).

4 Herman, C. C, D. R. Best, D. P. Lambert, M. E. Stone, and M. F. Williams, Sludge Batch 4 without Tank 4 Simulant Flowsheet Studies: Phase I SRAT Results, WSRC-TR-2005-00493, Savannah River Site, Aiken, SC 29808 (2005).

5 Shah, H.B., "Estimate of Sludge Batch 4 Calcine Composition Additional Cases for Final Recommendation", CBU-PIT-2006-00011, Savannah River Site, Aiken, SC 29808 (2006)

6 Herman, D. T., M. E. Stone, and M. R. Poirier, Preparation of Sludge Batch 4 Simulant, SRNL-WPT-2005-00130, Savannah River Site, Aiken, SC 29808 (2005).

7 Koopman D. C., Recommendations for SB4 Processing in the Shielded Cells, SRNL-PSE2006-00122, Revision 1, Savannah River Site, Aiken, SC 29808 (2006).

8 Stone, M. E., Lab-Scale CPC Equipment Set-up, SRNL-ITS-2006-00074, Savannah River Site, Aiken, SC 29808 (2006).

9 Manual L29, Procedure ITS-0094, Rev. 1, Laboratory Scale Chemical Process Cell Simulations, Savannah River Site, Aiken, SC 29808 (2005).

10 SB4 Simulant Flowsheet Testing: Phase II, WSRC-NB-2006-00087.

11 Lambert, D. P., Acid Calculation Spreadsheet for DWPF Simulations, Revision 1 (Dated 8/14/06), SRNL-PSE-2006-00173, Savannah River Site, Aiken, SC 29808 (2006).

12 Jantzen, C.M., J.R. Zamecnik, D.C. Koopman, C.C. Herman, and J.B. Pickett, Electron Equivalents Model for Controlling Reduction-Oxidation (Redox) Equilibrium during High Level Waste (HLW) Vitrification, WSRC-TR-2003-00126, Savannah River Site, Aiken, SC 29808 (2003).

13 Baich, M.A., Analytical Study Plan for Sludge Batch 4 with ARP and MCU Flowsheet Studies using Simulants, SRNL-GPD-2005-00001, Savannah River Site, Aiken, SC 29808 (2005).

14 Stone, M. E., 4L SB4 SRAT Run for Flowsheet Tests - 130\% Acid Stoichiometry: SB4-61, SRNL-PSE-2006-00137, Savannah River Site, Aiken, SC 29808 (2006).

15 Stone, M. E., 4L SB4 SRAT Run for Flowsheet Tests - 150\% Acid Stoichiometry: SB4-62, SRNL-PSE-2006-00138, Savannah River Site, Aiken, SC 29808 (2006).

16 Stone, M. E., 4L SB4 SRAT Run for Flowsheet Tests - 160\% Acid Stoichiometry: SB4-63, SRNL-PSE-2006-00139, Savannah River Site, Aiken, SC 29808 (2006).

17 Stone, M. E., 4L SB4 SRAT Run for Flowsheet Tests - 170\% Acid Stoichiometry: SB4-64, SRNL-PSE-2006-00140, Savannah River Site, Aiken, SC 29808 (2006).

18 Lambert, D. P, Testing of Irradiated and Nonirradiated IIT747 Antifoam in Simulated Sludge Processing, WSRC-RP-2000-00788, Savannah River Site, Aiken, SC 29808 (2000).

19 Koopman, D. C. Rheological Characterization of Unusual DWPF Slurry Samples, WSRCTR-2004-519, Savannah River Site, Aiken, SC 29808 (2005).

20 Stone, M. E., FY06 Feed Preparation for Melt Rate Testing, WSRC-STI-2006-0007, Savannah River Site, Aiken, SC 29808 (2006).

21 Koopman, D. C., D. P. Lambert, D. R. Best, M. J. Barnes, Impact of Preparation Methods and Scale Factors on Sludge Batch 4 Simulant Properties, WSRC-STI-2006-00088, Savannah River Site, Aiken, SC 29808 (2006). 
22 Smith, M. E., T. M. Jones, D. H. Miller, and M. E. Stone, SB4 SMRF Runs with Frits 418 and 320, WSRC-TR-2005-00569, Savannah River Site, Aiken, SC 29808 (2005).

23 Manual L29, Procedure ITS-0052, Rev. 1, "Vitrification of Melter Slurries for Glass Redox (Fe2+/ Fe) \& Chemical Composition Measurement", (2003). 


\subsection{Acknowledgements}

The authors would like to acknowledge the following personnel and groups for their assistance in performing the studies and analyzing the required samples:

- D. T. Herman, J. G. Wheeler, V. L. Bush, and S. A. Hatcher for assistance with and preparing the Spintek sludge simulant.

- D. H. Miller for preparation of the precurser based simulant.

- T. O. Burckhalter, J. W. Duvall, D. M. Marsh, I. A. Reamer, V. J. Williams, and R. J. Workman for performing the SRAT/SME runs and assisting with sample analysis.

- P. A. Toole, L. W. Brown, S. L. Crump, and L. C. Johnson for providing sample analyses.

- M. F. Williams and J. M. Pareizs for assistance with calibration and running the gas chromatographs during the runs.

- D. C. Koopman for reviewing the rheology analysis and for preparing simulant recipe calculations and simulants. 


\section{Appendix A. Sample and Run Results: Tabulated Presentations}

Table A- 1. SRAT Process Sample Results

\begin{tabular}{|c|c|c|c|c|c|c|c|c|c|c|}
\hline \multicolumn{5}{|c|}{ Process Samples: After Acid } & \multicolumn{3}{|c|}{ Process Samples: Hydrogen Onset } & \multicolumn{3}{|c|}{ Process Samples: Hydrogen Peak } \\
\hline & SB4-61 & SB4-62 & SB4-63 & SB4-64 & SB4-62 & SB4-63 & SB4-64 & SB4-62 & SB4-63 & SB4-64 \\
\hline & $130 \%$ & $150 \%$ & $160 \%$ & $170 \%$ & $150 \%$ & $160 \%$ & $170 \%$ & $150 \%$ & $160 \%$ & $170 \%$ \\
\hline \multicolumn{5}{|c|}{ Supernate elementals (mg/L) } & \multicolumn{3}{|c|}{ Supernate elementals (mg/L) } & \multicolumn{3}{|c|}{ Supernate elementals (mg/L) } \\
\hline $\mathrm{Al}$ & 140.5 & 405.5 & 268.5 & 429 & 12.4 & 91.85 & 247.5 & 2.945 & 100.2 & 222 \\
\hline $\mathrm{B}$ & 8.42 & 7.725 & 6.015 & 4.225 & 8.245 & 7.485 & 5.325 & 8.98 & 6.67 & 5.72 \\
\hline $\mathrm{Ba}$ & 0.939 & 1.46 & 0.607 & 0.546 & 1.32 & 1.095 & 1.0075 & 1.73 & 1.605 & 1.135 \\
\hline $\mathrm{Ca}$ & 2205 & 2240 & 2370 & 2330 & 2465 & 3045 & 2495 & 2965 & 3435 & 2975 \\
\hline $\mathrm{Cr}$ & 1.19 & 2.47 & 2.4 & 3.455 & $<0.100$ & 0.434 & 1.965 & $<0.100$ & 0.458 & 1.48 \\
\hline $\mathrm{Fe}$ & 4.655 & 23.2 & 17.7 & 36.45 & $<0.100$ & 3.83 & 12.45 & $<0.100$ & 29.7 & 84.2 \\
\hline $\mathrm{K}$ & 800.5 & 809.5 & 869 & 830 & 953.5 & 1190 & 933.5 & 1190 & 1335 & 1140 \\
\hline $\mathrm{Li}$ & $<10.0$ & $<10.0$ & $<10.0$ & $<10.0$ & $<10.0$ & $<10.0$ & $<10.0$ & $<10.0$ & $<10.0$ & $<10.0$ \\
\hline $\mathrm{Mg}$ & 2115 & 2135 & 2255 & 2225 & 2395 & 3000 & 2390 & 2905 & 3355 & 2890 \\
\hline $\mathrm{Mn}$ & 4525 & 4895 & 5265 & 5405 & 5520 & 7630 & 6010 & 6630 & 8740 & 7675 \\
\hline $\mathrm{Na}$ & 20300 & 20100 & 21650 & 21350 & 23350 & 29000 & 22600 & 27750 & 31850 & 27050 \\
\hline $\mathrm{Ni}$ & 547.5 & 686 & 798 & 864 & 497.5 & 932.5 & 944.5 & 310.5 & 1025 & 1135 \\
\hline$P$ & $<1.00$ & $<1.00$ & $<1.00$ & $<1.00$ & $<1.00$ & $<1.00$ & $<1.00$ & $<1.00$ & $<1.00$ & $<1.00$ \\
\hline $\mathrm{Pb}$ & 1.155 & 1.93 & 2.81 & 2.85 & $<0.100$ & 3.02 & 3.225 & $<0.100$ & 3.535 & 5.5 \\
\hline $\mathrm{Pd}$ & 6.115 & 5.55 & 4.94 & 4.255 & 0.909 & 0.9305 & 0.8865 & 0.894 & 0.8935 & 0.859 \\
\hline $\mathrm{Rh}$ & 26.2 & 30.75 & 31.9 & 31.8 & 4.14 & 4.905 & 8.24 & 1.53 & 4.53 & 7.845 \\
\hline $\mathrm{Ru}$ & 32 & 35.85 & 36.1 & 37.75 & 5.47 & 3.975 & 27 & $<0.100$ & 3.55 & 14.2 \\
\hline $\mathrm{S}$ & 470.5 & 480 & 536.5 & 523 & 545 & 676.5 & 550.5 & 669.5 & 767 & 668 \\
\hline $\mathrm{Sr}$ & 4.9 & 4.875 & 4.84 & 4.805 & 5.32 & 5.49 & 4.84 & 6.15 & 6.165 & 5.52 \\
\hline $\mathrm{Ti}$ & $<0.100$ & $<0.100$ & $<0.100$ & $<0.100$ & $<0.100$ & $<0.100$ & $<0.100$ & $<0.100$ & $<0.100$ & $<0.100$ \\
\hline $\mathrm{Zn}$ & 38.8 & 54.1 & 61.1 & 70.7 & 34.7 & 74.05 & 75.85 & 17.05 & 88.7 & 101 \\
\hline $\mathrm{Zr}$ & 0.1475 & 0.1955 & 0.148 & 0.152 & 0.129 & 0.159 & 0.142 & 0.1375 & 0.141 & 0.1505 \\
\hline \multicolumn{5}{|c|}{ Anions (mg/kg) } & \multicolumn{3}{|c|}{ Anions (mg/kg) } & \multicolumn{3}{|c|}{ Anions (mg/kg) } \\
\hline $\mathrm{NO} 2$ & 8145 & 4580 & 2275 & 1760 & $<100$ & $<100$ & $<100$ & $<100$ & $<100$ & $<100$ \\
\hline NO3 & 20170 & 21770 & 22300 & 23950 & 23895 & 26100 & 24850 & 29885 & 31250 & 28900 \\
\hline $\mathrm{HCO} 2$ & 51110 & 55635 & 53200 & 56450 & 58260 & 59600 & 57750 & 67300 & 66300 & 65900 \\
\hline SO4 & 2700 & 3045 & 3250 & 4225 & 3485 & 3485 & 3915 & 4890 & 5395 & 5745 \\
\hline PO4 & $<100$ & $<100$ & $<100$ & $<100$ & $<100$ & $<100$ & $<100$ & $<100$ & $<100$ & $<100$ \\
\hline $\mathrm{C} 2 \mathrm{O} 4$ & $<100$ & 260 & 282 & $<100$ & $<100$ & $<100$ & 242 & $<100$ & $<100$ & 175 \\
\hline $\mathrm{Cl}$ & 155 & 132.5 & 150 & 148.5 & 205 & 218 & 160 & 250 & 240 & 221 \\
\hline \multicolumn{5}{|c|}{ pH Data } & \multicolumn{3}{|c|}{ pH Data } & \multicolumn{3}{|c|}{ pH Data } \\
\hline $\mathrm{pH}$ & 4.65 & 4.41 & 3.98 & 3.67 & 5.14 & $\mathrm{~nm}$ & $\mathrm{~nm}$ & 5.91 & $\mathrm{~nm}$ & $\mathrm{~nm}$ \\
\hline \multicolumn{5}{|c|}{ Solids Data (wt \%) } & \multicolumn{3}{|c|}{ Solids Data (wt \%) } & \multicolumn{3}{|c|}{ Solids Data (wt \%) } \\
\hline TS & 19.3 & 19.2 & 19.3 & 19.3 & 21.3 & 23.6 & 20.0 & 25.3 & 26.2 & 23.5 \\
\hline IS & 10.6 & 10.3 & 10.5 & 10.3 & 11.6 & 12.6 & 10.7 & 13.5 & 14.2 & 12.4 \\
\hline Supernate & 9.7 & 9.9 & 9.9 & 10.1 & 11.0 & 12.6 & 10.5 & 13.6 & 14.0 & 12.6 \\
\hline SS & 8.7 & 8.9 & 8.9 & 9.1 & 9.7 & 11.0 & 9.4 & 11.8 & 12.0 & 11.1 \\
\hline
\end{tabular}


WSRC-STI-2006-00109

Revision 0

Table A- 2. SRAT Product Results

\begin{tabular}{|c|c|c|c|c|c|c|c|c|c|}
\hline & SB4-61 & SB4-62 & SB4-63 & SB4-64 & & SB4-61 & SB4-62 & SB4-63 & SB4-64 \\
\hline & $130 \%$ & $150 \%$ & $160 \%$ & $170 \%$ & & $130 \%$ & $150 \%$ & $160 \%$ & $170 \%$ \\
\hline \multicolumn{5}{|c|}{ Elementals (wt\% Calcine Solids) } & \multicolumn{5}{|c|}{ Oxide Results (wt\% calcine Solids) } \\
\hline $\mathrm{Al}$ & 15.3 & 15 & 15 & 14.9 & $\mathrm{~A} 12 \mathrm{O} 3$ & 28.92 & 28.35 & 28.35 & 28.16 \\
\hline B & $<0.100$ & $<0.100$ & $<0.100$ & $<0.100$ & B2O3 & 0.00 & 0.00 & 0.00 & 0.00 \\
\hline $\mathrm{Ba}$ & 0.156 & 0.156 & 0.154 & 0.154 & $\mathrm{BaO}$ & 0.174 & 0.174 & 0.172 & 0.172 \\
\hline $\mathrm{Ca}$ & 1.81 & 1.80 & 1.76 & 1.79 & $\mathrm{CaO}$ & 2.54 & 2.52 & 2.46 & 2.51 \\
\hline $\mathrm{Cr}$ & 0.130 & 0.124 & 0.121 & 0.118 & $\mathrm{Cr} 2 \mathrm{O} 3$ & 0.189 & 0.181 & 0.176 & 0.172 \\
\hline $\mathrm{Fe}$ & 20.8 & 20.1 & 19.45 & 19.85 & $\mathrm{Fe} 2 \mathrm{O} 3$ & 29.74 & 28.74 & 27.81 & 28.39 \\
\hline $\mathrm{K}$ & 0.350 & 0.3530 & 0.355 & 0.366 & $\mathrm{~K} 2 \mathrm{O}$ & 0.420 & 0.424 & 0.425 & 0.439 \\
\hline $\mathrm{Li}$ & $<0.100$ & $<0.100$ & $<0.100$ & $<0.100$ & $\mathrm{Li} 2 \mathrm{O}$ & 0.000 & 0.000 & 0.000 & 0.000 \\
\hline $\mathrm{Mg}$ & 1.461 & 1.461 & 1.50 & 1.54 & $\mathrm{MgO}$ & 2.43 & 2.43 & 2.49 & 2.56 \\
\hline $\mathrm{Mn}$ & 4.73 & 4.63 & 4.365 & 4.445 & $\mathrm{MnO} 2$ & 7.47 & 7.32 & 6.90 & 7.02 \\
\hline $\mathrm{Na}$ & 14.85 & 14.95 & 14.9 & 15.35 & $\mathrm{Na} 2 \mathrm{O}$ & 20.05 & 20.18 & 20.12 & 20.72 \\
\hline $\mathrm{Ni}$ & 1.4 & 1.395 & 1.395 & 1.355 & $\mathrm{NiO}$ & 1.78 & 1.77 & 1.77 & 1.72 \\
\hline $\mathrm{P}$ & 0.032 & 0.037 & 0.035 & 0.033 & $\mathrm{P} 2 \mathrm{O} 5$ & 0.073 & 0.085 & 0.080 & 0.076 \\
\hline $\mathrm{Pb}$ & 0.028 & 0.034 & 0.051 & 0.043 & $\mathrm{PbO}$ & 0.030 & 0.036 & 0.055 & 0.046 \\
\hline $\mathrm{Pd}$ & $<0.010$ & $<0.010$ & $<0.010$ & $<0.010$ & $\mathrm{PdO}$ & 0.000 & 0.000 & 0.000 & 0.000 \\
\hline $\mathrm{Rh}$ & 0.0141 & $<0.010$ & $<0.010$ & 0.0145 & $\mathrm{RhO} 2$ & 0.019 & 0.000 & 0.000 & 0.019 \\
\hline $\mathrm{Ru}$ & $<0.010$ & $<0.010$ & $<0.010$ & 0.0215 & $\mathrm{RuO} 2$ & 0.000 & 0.000 & 0.000 & 0.028 \\
\hline $\mathrm{S}$ & 0.446 & 0.447 & 0.438 & 0.441 & SO4 & 1.34 & 1.34 & 1.31 & 1.32 \\
\hline $\mathrm{Si}$ & 2.07 & 2 & 2.03 & 2.005 & $\mathrm{SiO} 2$ & 4.43 & 4.28 & 4.34 & 4.29 \\
\hline $\mathrm{Ti}$ & 0.027 & 0.027 & 0.027 & 0.027 & $\mathrm{TiO} 2$ & 0.045 & 0.000 & 0.045 & 0.000 \\
\hline $\mathrm{Zn}$ & 0.183 & 0.179 & 0.178 & 0.176 & $\mathrm{ZnO}$ & 0.226 & 0.222 & 0.220 & 0.218 \\
\hline $\mathrm{Zr}$ & 0.200 & 0.198 & 0.203 & 0.203 & $\mathrm{ZrO} 2$ & 0.271 & 0.267 & 0.273 & 0.273 \\
\hline \multicolumn{5}{|c|}{ Anions (mg/kg) } & \multicolumn{5}{|c|}{ Solids Data (wt \%) } \\
\hline $\mathrm{NO} 2$ & 260 & $<100$ & $<100$ & $<100$ & $\mathrm{TS}$ & 26.41 & 26.58 & 26.40 & 26.23 \\
\hline NO3 & 23400 & 26400 & 28700 & 30900 & IS & 15.44 & 14.42 & 14.08 & 13.62 \\
\hline $\mathrm{HCO} 2$ & 60800 & 63700 & 62900 & 67050 & SS & 10.97 & 12.16 & 12.32 & 12.61 \\
\hline $\mathrm{SO} 4$ & 1265 & 1495 & 1850 & 3025 & $\mathrm{CS}$ & 16.88 & 16.52 & 16.15 & 15.89 \\
\hline PO4 & $<100$ & $<100$ & $<100$ & $<100$ & & & & & \\
\hline $\mathrm{C} 2 \mathrm{O} 4$ & $<100$ & $<100$ & $<100$ & $<100$ & & & & & \\
\hline $\mathrm{Cl}$ & 270 & 265 & 245 & 238.5 & & & & & \\
\hline \multicolumn{5}{|c|}{ Density and $\mathrm{pH}$} & & & & & \\
\hline $\mathrm{pH}$ & 8.17 & 6.83 & 5.27 & 4.78 & & & & & \\
\hline Density & 1.2192 & 1.2172 & 1.2126 & 1.2099 & & & & & \\
\hline
\end{tabular}


WSRC-STI-2006-00109

Revision 0

Table A- 3. SRAT Product Supernate Results

\begin{tabular}{|c|c|c|c|c|c|c|c|c|c|c|}
\hline & SB4-61 & SB4-62 & SB4-63 & SB4-64 & & SB4-61 & SB4-62 & SB4-63 & SB4-64 \\
\hline \multicolumn{7}{|c|}{ Supernate Elementals (mg/L) } & \multicolumn{7}{|c|}{ Supernate Elementals (\% soluble) } \\
\hline $\mathrm{Al}$ & 1.395 & 1.33 & 4.22 & 101 & $\mathrm{Al}$ & 0.0046 & 0.0046 & 0.0150 & 0.3685 \\
\hline $\mathrm{B}$ & 1.695 & 5.82 & 10.335 & 12.25 & $\mathrm{~B}$ & & & & \\
\hline $\mathrm{Ba}$ & $<0.100$ & $<0.100$ & $<0.100$ & $<0.100$ & $\mathrm{Ba}$ & & & & \\
\hline $\mathrm{Ca}$ & 3185 & 3405 & 3365 & 3475 & $\mathrm{Ca}$ & 88.05 & 98.02 & 101.70 & 105.53 \\
\hline $\mathrm{Cr}$ & $<0.100$ & $<0.100$ & $<0.100$ & $<0.100$ & $\mathrm{Cr}$ & & & & \\
\hline $\mathrm{Fe}$ & $<0.100$ & $<0.100$ & 2.25 & 43 & $\mathrm{Fe}$ & & & 0.0062 & 0.1178 \\
\hline $\mathrm{K}$ & 1050 & 1045 & 1290 & 1280 & $\mathrm{~K}$ & 150.2 & 153.4 & 193.6 & 190.4 \\
\hline $\mathrm{Li}$ & 2.48 & 2.87 & 2.94 & 2.965 & $\mathrm{Li}$ & & & & \\
\hline $\mathrm{Mg}$ & 2695 & 3305 & 3245 & 3260 & $\mathrm{Mg}$ & 92.41 & 117.17 & 115.07 & 115.08 \\
\hline $\mathrm{Mn}$ & 2135 & 7240 & 8635 & 8855 & $\mathrm{Mn}$ & 22.62 & 81.01 & 105.22 & 108.30 \\
\hline $\mathrm{Na}$ & 32750 & 31550 & 30800 & 29250 & $\mathrm{Na}$ & 110.5 & 109.3 & 110.0 & 103.6 \\
\hline $\mathrm{Ni}$ & 0.162 & 28.45 & 753 & 1130 & $\mathrm{Ni}$ & 0.0058 & 1.0566 & 28.7116 & 45.3348 \\
\hline $\mathrm{P}$ & 1.975 & 1.585 & 1.051 & 1.105 & $\mathrm{P}$ & 3.090 & 2.225 & 1.597 & 1.820 \\
\hline $\mathrm{Pb}$ & $<0.200$ & $<0.200$ & 0.294 & 3.5 & $\mathrm{~Pb}$ & & & 0.310 & 4.477 \\
\hline $\mathrm{Pd}$ & $<0.500$ & $<0.500$ & $<0.500$ & $<0.500$ & $\mathrm{Pd}$ & & & & \\
\hline $\mathrm{Rh}$ & 1.655 & 1.14 & 1.425 & 1.57 & $\mathrm{Rh}$ & 5.87 & & & 5.89 \\
\hline $\mathrm{Ru}$ & $<0.100$ & $<0.100$ & 0.919 & 3.97 & $\mathrm{Ru}$ & & & & 10.04 \\
\hline $\mathrm{S}$ & 661 & 743 & 789.5 & 798.5 & $\mathrm{~S}$ & 74.32 & 86.08 & 95.88 & 98.54 \\
\hline $\mathrm{Si}$ & 21.85 & 28.55 & 82.55 & 114.5 & $\mathrm{Si}$ & 0.53 & 0.74 & 2.16 & 3.10 \\
\hline $\mathrm{Ti}$ & $<0.100$ & $<0.100$ & $<0.100$ & $<0.100$ & $\mathrm{Ti}$ & & & & \\
\hline $\mathrm{Zn}$ & $<0.100$ & 0.5725 & 69.4 & 120 & $\mathrm{Zn}$ & & 0.17 & 20.80 & 37.17 \\
\hline $\mathrm{Zr}$ & $<0.200$ & $<0.200$ & $<0.100$ & $<0.100$ & $\mathrm{Zr}$ & & & & \\
\hline
\end{tabular}


WSRC-STI-2006-00109

Revision 0

Table A- 4. SME Product Results

\begin{tabular}{|c|c|c|c|c|c|c|c|c|c|}
\hline & SB4-61 & SB4-62 & SB4-63 & SB4-64 & & SB4-61 & SB4-62 & SB4-63 & SB4-64 \\
\hline & $130 \%$ & $150 \%$ & $160 \%$ & $170 \%$ & & $130 \%$ & $150 \%$ & $160 \%$ & $170 \%$ \\
\hline \multicolumn{5}{|c|}{ Elementals (wt \% calcined solids) } & \multicolumn{5}{|c|}{ Oxides (wt \% calcine solids) } \\
\hline $\mathrm{Al}$ & 5.44 & 5.44 & 5.34 & 5.24 & $\mathrm{~A} 12 \mathrm{O} 3$ & 10.28 & 10.28 & 10.09 & 9.90 \\
\hline $\mathrm{B}$ & 2.94 & 2.83 & 2.88 & 2.87 & $\mathrm{~B} 2 \mathrm{O} 3$ & 9.47 & 9.12 & 9.26 & 9.23 \\
\hline $\mathrm{Ba}$ & 0.062 & 0.062 & 0.062 & 0.062 & $\mathrm{BaO}$ & 0.069 & 0.070 & 0.069 & 0.069 \\
\hline $\mathrm{Ca}$ & 0.626 & 0.623 & 0.578 & 0.615 & $\mathrm{CaO}$ & 0.876 & 0.872 & 0.809 & 0.860 \\
\hline $\mathrm{Cr}$ & 0.0488 & 0.0467 & 0.0520 & 0.0525 & $\mathrm{Cr} 2 \mathrm{O} 3$ & 0.071 & 0.068 & 0.076 & 0.077 \\
\hline $\mathrm{Fe}$ & 7.42 & 6.68 & 6.955 & 6.96 & $\mathrm{Fe} 2 \mathrm{O} 3$ & 10.61 & 9.55 & 9.95 & 9.95 \\
\hline $\mathrm{K}$ & 0.173 & 0.169 & 0.174 & 0.181 & $\mathrm{~K} 2 \mathrm{O}$ & 0.208 & 0.202 & 0.208 & 0.217 \\
\hline $\mathrm{Li}$ & 2.40 & 2.43 & 2.40 & 2.36 & $\mathrm{Li} 2 \mathrm{O}$ & 5.17 & 5.22 & 5.15 & 5.06 \\
\hline $\mathrm{Mg}$ & 0.582 & 0.579 & 0.577 & 0.590 & $\mathrm{MgO}$ & 0.966 & 0.961 & 0.958 & 0.979 \\
\hline $\mathrm{Mn}$ & 1.461 & 1.473 & 1.480 & 1.520 & $\mathrm{MnO} 2$ & 2.31 & 2.33 & 2.34 & 2.40 \\
\hline $\mathrm{Na}$ & 7.58 & 7.56 & 7.64 & 7.84 & $\mathrm{Na} 2 \mathrm{O}$ & 10.23 & 10.20 & 10.31 & 10.58 \\
\hline $\mathrm{Ni}$ & 0.489 & 0.497 & 0.486 & 0.477 & $\mathrm{NiO}$ & 0.620 & 0.631 & 0.617 & 0.606 \\
\hline $\mathrm{P}$ & 0.018 & 0.019 & 0.016 & 0.017 & $\mathrm{P} 2 \mathrm{O} 5$ & 0.041 & 0.043 & 0.035 & 0.039 \\
\hline$\overline{\mathrm{Pb}}$ & 0.045 & 0.045 & 0.042 & 0.041 & $\mathrm{PbO}$ & 0.048 & 0.049 & 0.045 & 0.044 \\
\hline $\mathrm{Pd}$ & $<0.010$ & $<0.010$ & $<0.010$ & $<0.010$ & $\mathrm{PdO}$ & 0.000 & 0.000 & 0.000 & 0.000 \\
\hline$\overline{\mathrm{Rh}}$ & $<0.010$ & $<0.010$ & $<0.010$ & $<0.010$ & RhO2 & 0.000 & 0.000 & 0.000 & 0.000 \\
\hline $\mathrm{Ru}$ & $<0.010$ & $<0.010$ & $<0.010$ & $<0.010$ & $\mathrm{RuO} 2$ & 0.000 & 0.000 & 0.000 & 0.000 \\
\hline $\mathrm{S}$ & 0.138 & 0.143 & 0.125 & 0.151 & $\mathrm{SO} 4$ & 0.415 & 0.429 & 0.374 & 0.453 \\
\hline $\mathrm{Si}$ & 22.7 & 22.1 & 22.3 & 22.0 & $\mathrm{SiO} 2$ & 48.61 & 47.19 & 47.62 & 47.08 \\
\hline $\mathrm{Sr}$ & $<0.010$ & $<0.010$ & $<0.010$ & $<0.010$ & $\mathrm{SrO}$ & 0.000 & 0.000 & 0.000 & 0.000 \\
\hline $\mathrm{Ti}$ & 0.013 & 0.013 & 0.013 & 0.013 & $\mathrm{TiO} 2$ & 0.022 & 0.000 & 0.022 & 0.000 \\
\hline $\mathrm{Zn}$ & 0.083 & 0.069 & 0.065 & 0.064 & $\mathrm{ZnO}$ & 0.103 & 0.085 & 0.081 & 0.079 \\
\hline $\mathrm{Zr}$ & 0.077 & 0.077 & 0.076 & 0.074 & $\mathrm{ZrO} 2$ & 0.103 & 0.104 & 0.102 & 0.100 \\
\hline \multicolumn{5}{|c|}{ Anions (mg/kg) } & & & & & \\
\hline $\mathrm{NO} 2$ & 101.5 & $<100$ & $<100$ & $<100$ & & & & & \\
\hline NO3 & 20200 & 22550 & 24950 & 23000 & & & & & \\
\hline $\mathrm{HCO} 2$ & 52450 & 55500 & 57450 & 58600 & & & & & \\
\hline SO4 & 2130 & 2525 & 1965 & 2725 & & & & & \\
\hline PO4 & $<100$ & $<100$ & $<100$ & $<100$ & & & & & \\
\hline $\mathrm{C} 2 \mathrm{O} 4$ & 130 & $<100$ & $<100$ & $<100$ & & & & & \\
\hline $\mathrm{Cl}$ & 220 & 215 & 206 & 203.5 & & & & & \\
\hline \multicolumn{5}{|c|}{ pH and Density } & & & & & \\
\hline $\mathrm{pH}$ & 7.43 & 6.98 & 5.72 & 5.35 & & & & & \\
\hline Density & 1.3996 & 1.4244 & 1.4126 & 1.4044 & & & & & \\
\hline \multicolumn{5}{|c|}{ Solids } & & & & & \\
\hline TS & 46.64712 & 47.56768 & 46.82634 & 47.13318 & & & & & \\
\hline IS & 37.31269 & 37.26456 & 35.9447 & 36.04549 & & & & & \\
\hline SS & 9.334431 & 10.30312 & 10.88163 & 11.08769 & & & & & \\
\hline $\mathrm{CS}$ & 38.80945 & 39.11076 & 38.3146 & 38.16292 & & & & & \\
\hline \multicolumn{5}{|c|}{ Waste Loading } & & & & & \\
\hline & 35.43469 & 34.71821 & 35.63438 & 36.70938 & & & & & \\
\hline
\end{tabular}


WSRC-STI-2006-00109

Revision 0

Table A- 5. SME Product Supernate Results

\begin{tabular}{|c|c|c|c|c|c|c|c|c|c|}
\hline & SB4-61 & SB4-62 & SB4-63 & SB4-64 & & SB4-61 & SB4-62 & SB4-63 & SB4-64 \\
\hline & $130 \%$ & $150 \%$ & $160 \%$ & $170 \%$ & & $130 \%$ & $150 \%$ & $160 \%$ & $170 \%$ \\
\hline \multicolumn{5}{|c|}{ Supernate Elementals (mg/L) } & \multicolumn{5}{|c|}{$\begin{array}{l}\text { Supernate Elementals (\% } \\
\text { Soluble) }\end{array}$} \\
\hline $\mathrm{Al}$ & 1.25 & 1.285 & 2.11 & 6.355 & $\mathrm{Al}$ & 0.004 & 0.004 & 0.007 & 0.020 \\
\hline$B$ & 768 & 1060 & 1015 & 1185 & B & 4.220 & 6.002 & 5.902 & 6.931 \\
\hline $\mathrm{Ba}$ & $<0.100$ & $<0.100$ & $<0.100$ & $<0.100$ & $\mathrm{Ba}$ & & & & \\
\hline $\mathrm{Ca}$ & 3560 & 3650 & 3900 & 4085 & $\mathrm{Ca}$ & 91.932 & 93.977 & 112.902 & 111.404 \\
\hline $\mathrm{Cr}$ & $<0.100$ & $<0.100$ & $<0.100$ & $<0.100$ & $\mathrm{Cr}$ & & & & \\
\hline $\mathrm{Fe}$ & $<0.100$ & $<0.100$ & 3.38 & 11.8 & $\mathrm{Fe}$ & & & 0.008 & 0.028 \\
\hline $\mathrm{K}$ & 993 & 991 & 1510 & 1515 & $\mathrm{~K}$ & 92.582 & 94.272 & 145.502 & 140.270 \\
\hline $\mathrm{Li}$ & 1750 & 1960 & 1205 & 1390 & $\mathrm{Li}$ & 11.766 & 12.943 & 8.411 & 9.891 \\
\hline $\mathrm{Mg}$ & 3155 & 3600 & 3685 & 3740 & $\mathrm{Mg}$ & 87.570 & 99.748 & 106.771 & 106.230 \\
\hline $\mathrm{Mn}$ & 2855 & 6970 & 9495 & 9455 & $\mathrm{Mn}$ & 31.560 & 75.897 & 107.257 & 104.243 \\
\hline $\mathrm{Na}$ & 36500 & 36000 & 34700 & 34850 & $\mathrm{Na}$ & 77.780 & 76.434 & 75.932 & 74.493 \\
\hline $\mathrm{Ni}$ & 4.895 & 27.4 & 558.5 & 917.5 & $\mathrm{Ni}$ & 0.162 & 0.885 & 19.212 & 32.234 \\
\hline $\mathrm{P}$ & 2.07 & 1.775 & 1.265 & 0.971 & $\mathrm{P}$ & 1.879 & 1.520 & 1.364 & 0.957 \\
\hline $\mathrm{Pb}$ & $<0.200$ & $<0.200$ & $<0.200$ & $<0.200$ & $\mathrm{~Pb}$ & & & & \\
\hline $\mathrm{Pd}$ & $<0.500$ & $<0.500$ & $<0.500$ & $<0.500$ & $\mathrm{Pd}$ & & & & \\
\hline $\mathrm{Rh}$ & 1.51 & 1.105 & 1.15 & 1.285 & $\mathrm{Rh}$ & & & & \\
\hline $\mathrm{Ru}$ & $<0.100$ & $<0.100$ & 0.691 & 2.66 & $\mathrm{Ru}$ & & & & \\
\hline $\mathrm{S}$ & 1010 & 1030 & 980.5 & 971.5 & $\mathrm{~S}$ & 118.067 & 115.569 & 131.665 & 107.819 \\
\hline $\mathrm{Si}$ & 36.4 & 50.05 & 69.8 & 89.6 & $\mathrm{Si}$ & 0.026 & 0.036 & 0.052 & 0.068 \\
\hline $\mathrm{Sr}$ & 7.35 & 8.445 & 8.66 & 8.815 & $\mathrm{Sr}$ & & & & \\
\hline $\mathrm{Ti}$ & $<0.100$ & $<0.100$ & $<0.100$ & $<0.100$ & $\mathrm{Ti}$ & & & & \\
\hline $\mathrm{Zn}$ & $<0.100$ & $<0.100$ & 45.3 & 97.7 & $\mathrm{Zn}$ & & & 11.651 & 25.583 \\
\hline $\mathrm{Zr}$ & $<0.200$ & $<0.200$ & $<0.100$ & $<0.100$ & $\mathrm{Zr}$ & & & & \\
\hline
\end{tabular}


WSRC-STI-2006-00109

Revision 0

Table A- 6. Condensate Sample Results

\begin{tabular}{|c|c|c|c|c|c|c|c|c|c|c|c|c|c|c|c|c|}
\hline & \multicolumn{4}{|c|}{ SRAT Dewater } & \multicolumn{4}{|c|}{ SME Dewater } & \multicolumn{4}{|c|}{ MWWT } & \multicolumn{4}{|c|}{ FAVC } \\
\hline & SB4-61 & SB4-62 & SB4-63 & SB4-64 & SB4-61 & SB4-62 & SB4-63 & SB4-64 & SB4-61 & SB4-62 & SB4-63 & SB4-64 & SB4-61 & SB4-62 & SB4-63 & SB4-64 \\
\hline & $130 \%$ & $150 \%$ & $160 \%$ & $170 \%$ & $130 \%$ & $150 \%$ & $160 \%$ & $170 \%$ & $130 \%$ & $150 \%$ & $160 \%$ & $170 \%$ & $130 \%$ & $150 \%$ & $160 \%$ & $170 \%$ \\
\hline \multicolumn{17}{|c|}{ Elementals (mg/L) } \\
\hline $\mathrm{Al}$ & 0.15 & 0.1435 & 0.1395 & 0.151 & 0.12 & 0.117 & 0.1275 & 0.1235 & 0.1365 & 0.124 & 0.128 & 0.169 & 0.3615 & 0.4365 & 0.3825 & 0.226 \\
\hline $\mathrm{B}$ & 0.0985 & 0.0765 & 0.107 & 0.074 & 0.3335 & 0.3095 & 0.2615 & 0.3235 & 0.065 & 0.0645 & 0.05 & 0.0565 & 0.712 & 0.2965 & 0.25 & 0.297 \\
\hline $\mathrm{Ba}$ & $<0.010$ & $<0.010$ & $<0.010$ & $<0.010$ & $<0.010$ & $<0.010$ & $<0.010$ & $<0.010$ & $<0.010$ & $<0.010$ & $<0.010$ & $<0.010$ & $<0.010$ & $<0.010$ & $<0.010$ & $<0.010$ \\
\hline $\mathrm{Ca}$ & 0.169 & 0.081 & 0.1015 & 0.097 & 0.059 & 0.0635 & 0.116 & 0.0625 & 0.057 & 0.0595 & 0.061 & 0.075 & 0.272 & 0.1155 & 0.3805 & 0.191 \\
\hline $\mathrm{Cd}$ & $<0.010$ & $<0.010$ & $<0.010$ & $<0.010$ & $<0.010$ & $<0.010$ & $<0.010$ & $<0.010$ & $<0.010$ & $<0.010$ & $<0.010$ & $<0.010$ & $<0.010$ & $<0.010$ & $<0.010$ & $<0.010$ \\
\hline $\mathrm{Cr}$ & 0.0335 & $<0.010$ & $<0.010$ & $<0.010$ & $<0.010$ & $<0.010$ & $<0.010$ & $<0.010$ & $<0.010$ & $<0.010$ & $<0.010$ & $<0.010$ & 2.18 & $<0.010$ & $<0.010$ & $<0.010$ \\
\hline $\mathrm{Fe}$ & 0.1405 & $<0.010$ & $<0.010$ & $<0.010$ & $<0.010$ & $<0.010$ & $<0.010$ & $<0.010$ & $<0.010$ & $<0.010$ & $<0.010$ & $<0.010$ & 5.4 & 0.5035 & $<0.010$ & $<0.010$ \\
\hline $\bar{K}$ & 0.2085 & 0.193 & 0.195 & 0.191 & 0.2025 & 0.191 & 0.194 & 0.1905 & 0.194 & 0.189 & 0.1895 & 0.1935 & 0.2715 & 0.256 & 0.2875 & 0.2265 \\
\hline $\mathrm{Li}$ & $<0.100$ & $<0.100$ & $<0.100$ & $<0.100$ & $<0.100$ & $<0.100$ & $<0.100$ & $<0.100$ & $<0.100$ & $<0.100$ & $<0.100$ & $<0.100$ & $<0.100$ & $<0.100$ & $<0.100$ & $<0.100$ \\
\hline $\mathrm{Mg}$ & $<0.010$ & $<0.010$ & $<0.010$ & $<0.010$ & $<0.010$ & $<0.010$ & $<0.010$ & $<0.010$ & $<0.010$ & $<0.010$ & $<0.010$ & $<0.010$ & 0.084 & $<0.010$ & 0.232 & $<0.010$ \\
\hline $\mathrm{Mn}$ & $<0.010$ & $<0.010$ & $<0.010$ & $<0.010$ & $<0.010$ & $<0.010$ & $<0.010$ & $<0.010$ & $<0.010$ & $<0.010$ & $<0.010$ & $<0.010$ & 0.8185 & 0.0465 & 0.7495 & 0.185 \\
\hline $\mathrm{Na}$ & $<0.100$ & $<0.100$ & $<0.100$ & $<0.100$ & $<0.100$ & $<0.100$ & $<0.100$ & $<0.100$ & $<0.100$ & $<0.100$ & $<0.100$ & $<0.100$ & $<0.100$ & $<0.100$ & $<0.100$ & $<0.100$ \\
\hline $\mathrm{Ni}$ & 0.1335 & $<0.010$ & $<0.010$ & $<0.010$ & $<0.010$ & $<0.010$ & $<0.010$ & $<0.010$ & $<0.010$ & $<0.010$ & $<0.010$ & $<0.010$ & 0.059 & $<0.010$ & 0.053 & $<0.010$ \\
\hline $\mathrm{Pb}$ & $<0.020$ & $<0.020$ & $<0.020$ & $<0.020$ & $<0.020$ & $<0.020$ & $<0.020$ & $<0.020$ & $<0.020$ & $<0.020$ & $<0.020$ & $<0.020$ & $<0.020$ & $<0.020$ & $<0.020$ & $<0.020$ \\
\hline $\mathrm{S}$ & $<0.200$ & $<0.200$ & $<0.200$ & $<0.200$ & $<0.200$ & $<0.200$ & $<0.200$ & $<0.200$ & $<0.200$ & $<0.200$ & $<0.200$ & $<0.200$ & $<0.200$ & $<0.200$ & $<0.200$ & $<0.200$ \\
\hline $\mathrm{Si}$ & 62.25 & 93.05 & 130 & 151 & 21.4 & 36.5 & 68.3 & 73.9 & 99.6 & 77.95 & 55.25 & 68.45 & 52.45 & 73.25 & 112 & 144.5 \\
\hline $\mathrm{Ti}$ & $<0.010$ & $<0.010$ & $<0.010$ & $<0.010$ & $<0.010$ & $<0.010$ & $<0.010$ & $<0.010$ & $<0.010$ & $<0.010$ & $<0.010$ & $<0.010$ & $<0.010$ & $<0.010$ & $<0.010$ & $<0.010$ \\
\hline $\mathrm{Zn}$ & $<0.010$ & $<0.010$ & $<0.010$ & $<0.010$ & $<0.010$ & $<0.010$ & $<0.010$ & $<0.010$ & $<0.010$ & $<0.010$ & $<0.010$ & $<0.010$ & $<0.010$ & $<0.010$ & $<0.010$ & $<0.010$ \\
\hline $\mathrm{Zr}$ & $<0.100$ & $<0.100$ & 0.0165 & 0.015 & $<0.100$ & $<0.100$ & 0.015 & 0.0145 & $<0.100$ & $<0.100$ & 0.015 & 0.015 & $<0.100$ & $<0.100$ & 0.0295 & 0.0195 \\
\hline \multicolumn{17}{|c|}{ Anions (mg/kg) } \\
\hline $\mathrm{NO} 2$ & $<100$ & $<100$ & $<100$ & $<100$ & $<100$ & $<100$ & $<100$ & $<100$ & $<100$ & $<100$ & $<100$ & $<100$ & $<100$ & $<100$ & $<100$ & $<100$ \\
\hline $\mathrm{NO3}$ & 4135 & $<100$ & 2250 & 2595 & $<100$ & $<100$ & $<100$ & $<100$ & $<100$ & $<100$ & $<100$ & $<100$ & 290500 & 228000 & 255500 & 210000 \\
\hline $\mathrm{HCO} 2$ & 579.5 & 1085 & 2185 & 3410 & $<100$ & $<100$ & 635.5 & 1080 & $<100$ & $<100$ & 828 & 1820 & $<100$ & $<100$ & 977 & 1345 \\
\hline $\mathrm{SO} 4$ & $<100$ & $<100$ & $<100$ & $<100$ & $<100$ & $<100$ & $<100$ & $<100$ & $<100$ & $<100$ & $<100$ & $<100$ & 162 & 157 & $<100$ & 142.5 \\
\hline $\mathrm{PO} 4$ & 0.116 & 0.063 & $<100$ & $<100$ & 0.063 & 0.078 & $<100$ & $<100$ & 0.377 & 0.19 & $<100$ & $<100$ & 0.096 & 0 & $<100$ & $<100$ \\
\hline $\mathrm{C} 2 \mathrm{O} 4$ & $<100$ & $<100$ & $<100$ & $<100$ & $<100$ & $<100$ & $<100$ & $<100$ & $<100$ & $<100$ & $<100$ & $<100$ & $<100$ & $<100$ & $<100$ & $<100$ \\
\hline $\mathrm{Cl}$ & $<100$ & $<100$ & $<100$ & $<100$ & $<100$ & $<100$ & $<100$ & $<100$ & $<100$ & $<100$ & $<100$ & $<100$ & $<100$ & $<100$ & $<100$ & $<100$ \\
\hline $\mathrm{F}$ & $<100$ & $<100$ & $\mathrm{~nm}$ & $\mathrm{~nm}$ & $<100$ & $<100$ & $\overline{\mathrm{nm}}$ & $\mathrm{nm}$ & $<100$ & $<100$ & $\mathrm{~nm}$ & $\mathrm{~nm}$ & $<100$ & $<100$ & $\overline{\mathrm{nm}}$ & $\overline{\mathrm{nm}}$ \\
\hline \multicolumn{17}{|c|}{ pH and Density } \\
\hline$\overline{\mathrm{pH}}$ & 1.74 & 1.38 & 1.59 & $<1.00$ & 9.27 & 3.41 & 2.8 & 1.35 & 9.56 & 3.08 & 2.97 & 1.51 & 2.44 & 2.32 & 2.44 & 2.51 \\
\hline Density & 1.01 & 1 & 1 & 1 & 1 & 1 & 1 & 1 & 1 & 1.01 & 1 & 1 & 1.15 & 1.12 & 1.14 & 1.13 \\
\hline
\end{tabular}


WSRC-STI-2006-00109

Revision 0

Table A- 7. Formate and Nitrate Balance

\begin{tabular}{|c|c|c|c|c|c|}
\hline Inputs & Units & SB4-61 & SB4-62 & SB4-63 & SB4-64 \\
\hline Acid Stiochiometry & & $130 \%$ & $150 \%$ & $160 \%$ & $170 \%$ \\
\hline Sludge Added & grams & $2,845.0$ & $2,845.0$ & $2,845.0$ & $2,845.0$ \\
\hline Heel & grams & 0 & 0 & 0 & 0 \\
\hline Sludge Nitrite & $\mathrm{mg} / \mathrm{kg}$ & 14,495 & 14,495 & 14,495 & 14,495 \\
\hline Sludge Nitrate & $\mathrm{mg} / \mathrm{kg}$ & 9331 & 9331 & 9331 & 9331 \\
\hline Nitric Added & $\mathrm{ml}$ & 17.147 & 28.461 & 34.087 & 39.797 \\
\hline Nitric Molarity & molar & 10.57 & 10.57 & 10.57 & 10.57 \\
\hline Formic Added & $\mathrm{ml}$ & 139.084 & 156.596 & 165.365 & 174.097 \\
\hline Formic Molarity & molar & 23.6 & 23.6 & 23.6 & 23.6 \\
\hline SRAT Product & grams & 2245 & 2333 & 2376 & 2420 \\
\hline SRAT Product Nitrite & $\mathrm{mg} / \mathrm{kg}$ & 260 & 0 & 0 & 0 \\
\hline SRAT Product Nitrate & $\mathrm{mg} / \mathrm{kg}$ & 23400 & 26400 & 28700 & 30900 \\
\hline SRAT Product Formate & $\mathrm{mg} / \mathrm{kg}$ & 60800 & 63700 & 62900 & 67050 \\
\hline \multicolumn{6}{|l|}{ Calculations } \\
\hline \multicolumn{6}{|l|}{ SRAT Data } \\
\hline Nitrite in start of batch & moles & 0.896 & 0.896 & 0.896 & 0.896 \\
\hline Nitrate in start of batch & moles & 0.428 & 0.428 & 0.428 & 0.428 \\
\hline Formate in start of batch & moles & 0.000 & 0.000 & 0.000 & 0.000 \\
\hline Nitrate added & moles & 0.181 & 0.301 & 0.360 & 0.421 \\
\hline Formate added & moles & 3.282 & 3.696 & 3.903 & 4.109 \\
\hline Nitrate in end of batch & moles & 0.847 & 0.993 & 1.100 & 1.206 \\
\hline Formate in end of batch & moles & 3.034 & 3.302 & 3.321 & 3.606 \\
\hline Nitrate In & moles & 0.609 & 0.729 & 0.788 & 0.849 \\
\hline Nitrite Converted & moles & 0.238 & 0.264 & 0.311 & 0.357 \\
\hline Formate In & moles & 3.282 & 3.696 & 3.903 & 4.109 \\
\hline Formate Destroyed & moles & 0.249 & 0.394 & 0.581 & 0.503 \\
\hline Nitrite Conversion & $\%$ & 26.55 & 29.47 & 34.74 & 39.85 \\
\hline Formate Destruction & $\%$ & 7.58 & 10.66 & 14.90 & 12.24 \\
\hline \multicolumn{6}{|l|}{ SME Product Data } \\
\hline $\begin{array}{l}\text { SRAT Product Sample } \\
\text { Size }\end{array}$ & grams & 306 & 342 & 314 & 327 \\
\hline SME product & grams & 2424 & 2478 & 2506 & 2533 \\
\hline Nitrate & $\mathrm{mg} / \mathrm{kg}$ & 20200 & 22550 & 24950 & 23000 \\
\hline Formate & $\mathrm{mg} / \mathrm{kg}$ & 52450 & 55500 & 57450 & 58600 \\
\hline Nitrate in end of batch & moles & 0.79 & 0.90 & 1.01 & 0.94 \\
\hline Formate in end of batch & moles & 2.83 & 3.06 & 3.20 & 3.30 \\
\hline Formate Added & grams & 8.766 & 8.8 & 8.82 & 8.84 \\
\hline Nitrate Lost & moles & -0.058 & -0.054 & -0.054 & 0.104 \\
\hline Formate Lost & moles & 0.384 & 0.422 & 0.298 & 0.484 \\
\hline Nitrate Lost & $\%$ & -6.83 & -5.41 & -4.92 & 8.58 \\
\hline Formate Lost & $\%$ & 12.65 & 12.77 & 8.98 & 13.42 \\
\hline
\end{tabular}


Table A- 8. SRAT Cycle Run Data

\begin{tabular}{|c|c|c|c|c|c|}
\hline Parameter & Units & SB4-61 & SB4-62 & SB4-63 & SB4-64 \\
\hline & & $130 \%$ & $150 \%$ & $160 \%$ & $170 \%$ \\
\hline GC Calibration Gas & & AL1276 & AL1276 & AL1276 & AL1276 \\
\hline Pre-Run Leak Check In & $\mathrm{ml} / \mathrm{min}$ & 90 & 90 & 90 & 90 \\
\hline Pre-Run Leak Check Out & $\mathrm{ml} / \mathrm{min}$ & 86.8 & 91.6 & 84.5 & 85.8 \\
\hline Post-Run Leak Check In & $\mathrm{ml} / \mathrm{min}$ & 90 & 90 & 90 & 90 \\
\hline Post-Run Leak Check Out & $\mathrm{ml} / \mathrm{min}$ & 95.3 & 83.6 & 87.8 & 91.1 \\
\hline pH Pre-Run Cal: Buffer 4 & & 4.01 & 4.01 & 4.01 & 4.01 \\
\hline pH Pre-Run Cal: Buffer 10 & & 10 & 10 & 10 & 10.03 \\
\hline pH Pre-Run Cal: Buffer 7 & & 7.03 & 6.97 & 7.09 & 6.99 \\
\hline pH Post-Run Cal: Buffer 4 & & 4.4 & 4.08 & 4.4 & 4.08 \\
\hline pH Post-Run Cal: Buffer 10 & & 10 & 9.49 & 10.06 & 9.54 \\
\hline pH Post-Run Cal: Buffer 7 & & 7.31 & 6.77 & 7.4 & 6.82 \\
\hline Air Purge & $\mathrm{ml} / \mathrm{min}$ & 728.3 & 728.3 & 728.3 & 728.3 \\
\hline He Purge & $\mathrm{ml} / \mathrm{min}$ & 3.64 & 3.64 & 3.64 & 3.64 \\
\hline MWWT Water Added & grams & 48.5 & 53.9 & 60.7 & 52.3 \\
\hline MWWT Final Mass & grams & 50.64 & 53.93 & 56.72 & 58.18 \\
\hline FAVC Final Mass & grams & 27.65 & 25.59 & 24.32 & 24.59 \\
\hline \multicolumn{6}{|l|}{ Additions } \\
\hline Sludge Added & grams & 2845 & 2845 & 2845 & 2845 \\
\hline AgNO3 & grams & 0.0882 & 0.0884 & 0.088 & 0.0882 \\
\hline $\mathrm{HgO}$ & grams & 5.4018 & 5.4016 & 5.4015 & 5.4017 \\
\hline $\mathrm{Pd}(\mathrm{NO} 3) 2 * \mathrm{H} 2 \mathrm{O}$ & grams & 0.0492 & 0.049 & 0.0493 & 0.0489 \\
\hline $\mathrm{Rh}(\mathrm{NO} 3) 3 * 2 \mathrm{H} 2 \mathrm{O}$ & grams & 1.0961 & 1.0958 & 1.0956 & 1.0956 \\
\hline $\mathrm{RuCl3}$ & grams & 0.5908 & 0.5907 & 0.591 & 0.5911 \\
\hline Flush Water & grams & 50 & 50 & 50 & 50 \\
\hline Antifoam prior to acid & grams & 5.8 & 5.8 & 5.8 & 5.8 \\
\hline Water with 1 st antifoam addition & grams & 5.78 & 5.8 & 5.8 & 5.8 \\
\hline Additional Antifoam & & 2.91 & 0 & 2.9 & 0 \\
\hline Water with addition antifoam & & 2.96 & 0 & 2.9 & 0 \\
\hline Antifoam prior to boiling & grams & 14.51 & 14.51 & 14.51 & 14.51 \\
\hline Water with 2nd antifoam addition & grams & 14.51 & 14.51 & 14.51 & 14.51 \\
\hline Total & grams & 46.47 & 40.62 & 46.42 & 40.62 \\
\hline Ratio: Formic to Nitric Acid & & 0.9477 & 0.9247 & 0.9155 & 0.9071 \\
\hline \multicolumn{6}{|l|}{ Nitric Acid } \\
\hline Molarity & Molar & 10.57 & 10.57 & 10.57 & 10.57 \\
\hline Target Addition & $\mathrm{ml}$ & 17.147 & 28.461 & 34.087 & 39.797 \\
\hline Start Time & & 826 & 810 & 1824 & 1810 \\
\hline Starting Weight & grams & 1525.9 & 1228.4 & 1518.6 & 1503.5 \\
\hline Target Flowrate & $\mathrm{ml} / \mathrm{min}$ & 0.84 & 0.84 & 0.84 & 0.84 \\
\hline End Time & & 901 & 848 & 1903 & 1858 \\
\hline Ending Weight & grams & 1504 & 1190 & 1473.6 & 1452 \\
\hline
\end{tabular}


WSRC-STI-2006-00109

Revision 0

\begin{tabular}{|l|c|c|c|c|c|}
\hline Parameter & Units & SB4-61 & SB4-62 & SB4-63 & SB4-64 \\
\hline & & $\mathbf{1 3 0 \%}$ & $\mathbf{1 5 0 \%}$ & $\mathbf{1 6 0 \%}$ & $\mathbf{1 7 0 \%}$ \\
\hline Addition Time & min & 35 & 38 & 39 & 48 \\
\hline Addition Weight & grams & 21.9 & 38.4 & 45 & 51.5 \\
\hline Addition Volume & $\mathrm{ml}$ & 16.7 & 29.3 & 34.4 & 39.3 \\
\hline \% of Target & & -2.5 & 3.0 & 0.8 & -1.2 \\
\hline Actual Flowrate & $\mathrm{ml} / \mathrm{min}$ & 0.48 & 0.77 & 0.88 & 0.82 \\
\hline & & & & & \\
\hline Formic Acid & & & & & \\
\hline Molarity & Molar & 23.6 & 23.6 & 23.6 & 23.6 \\
\hline Target Addition & $\mathrm{ml}$ & 139.084 & 156.596 & 165.365 & 174.097 \\
\hline Start Time & & 910 & 859 & 1911 & 1917 \\
\hline Starting Weight & grams & 1391.7 & 1619.3 & 1352.7 & 1296.1 \\
\hline Target Flowrate & $\mathrm{ml} / \mathrm{min}$ & 0.85 & 0.85 & 0.85 & 0.85 \\
\hline End Time & & 1156 & 1207 & 2230 & 2246 \\
\hline Ending Weight & grams & 1225.5 & 1432.3 & 1155.5 & 1088.4 \\
\hline Addition Time & min & 166 & 188 & 199 & 209 \\
\hline Addition Weight & grams & 166.2 & 187 & 197.2 & 207.7 \\
\hline Addition Volume & $\mathrm{ml}$ & 137.4 & 154.5 & 163.0 & 171.7 \\
\hline \% of Target & & -1.2 & -1.3 & -1.4 & -1.4 \\
\hline Actual Flowrate & $\mathrm{ml} / \mathrm{min}$ & 0.83 & 0.82 & 0.82 & 0.82 \\
\hline
\end{tabular}


WSRC-STI-2006-00109

Revision 0

Table A- 9. SME Cycle Run Data

\begin{tabular}{|c|c|c|c|c|c|}
\hline Parameter & Units & SB4-61 & SB4-62 & SB4-63 & SB4-64 \\
\hline & & $130 \%$ & $150 \%$ & $160 \%$ & $170 \%$ \\
\hline Air Purge & $\mathrm{ml} / \mathrm{min}$ & 208 & 209 & 210 & 210 \\
\hline He Purge & $\mathrm{ml} / \mathrm{min}$ & 1.04 & 1.05 & 1.05 & 1.05 \\
\hline Boil-Up Rate Target & grams/min & 3.78 & 3.79 & 3.8 & 3.81 \\
\hline Antifoam Addition & grams & 2 & 2.08 & 2.9 & 2.9 \\
\hline Water with Antifoam & grams & 2 & 2.08 & 2.9 & 2.9 \\
\hline \multicolumn{6}{|l|}{ Frit Addition 1} \\
\hline Frit amount & grams & 291.9 & 293.3 & 293.92 & 294.5 \\
\hline Formic Amount & grams & 4.383 & 4.4 & 4.41 & 4.42 \\
\hline Water Amount & grams & 287.5 & 288.9 & 289.54 & 290.1 \\
\hline Start of Boiling & & 508 & 1620 & 1642 & \\
\hline Dewater & grams & 292.13 & 293.3 & 294 & 299.4 \\
\hline End of Boiling & & 629 & 1829 & & 1555 \\
\hline Time at Boiling & $\min$ & 81 & 129 & & \\
\hline Boil-Up Rate & $\mathrm{g} / \mathrm{min}$ & 3.61 & 2.27 & & \\
\hline \multicolumn{6}{|l|}{ Frit Addition 2} \\
\hline Frit amount & grams & 291.9 & 293.3 & 293.88 & 294.5 \\
\hline Formic Amount & grams & 4.383 & 4.4 & 4.41 & 4.42 \\
\hline Water Amount & grams & 287.5 & 258.9 & 289.45 & 290.1 \\
\hline Start of Boiling & & 730 & 710 & 1650 & 1641 \\
\hline Dewater & grams & 293.57 & 293.77 & 293.9 & 294.5 \\
\hline End of Boiling & & 837 & 827 & 1742 & 1755 \\
\hline Time at Boiling & $\min$ & 67 & 77 & 52 & 74 \\
\hline Boil-Up Rate & $\mathrm{g} / \mathrm{min}$ & 4.38 & 3.82 & 5.65 & 3.98 \\
\hline \multicolumn{6}{|l|}{ Total Frit Additions } \\
\hline Frit amount & grams & 583.8 & 586.6 & 587.8 & 589 \\
\hline Formic Amount & grams & 8.766 & 8.8 & 8.82 & 8.84 \\
\hline Water Amount & grams & 575 & 547.8 & 578.99 & 580.2 \\
\hline Dewater & grams & 585.7 & 587.07 & 587.9 & 593.9 \\
\hline Time at Boiling & $\min$ & 148 & 206 & 52 & 74 \\
\hline Final Dewater Amount & grams & 152.22 & 195.03 & 214.2 & 238.2 \\
\hline End of Boiling & & 957 & 1011 & 1845 & 1855 \\
\hline Time at Boiling & $\min$ & 39 & 104 & 63 & 60 \\
\hline Boil-Up Rate & $\mathrm{g} / \mathrm{min}$ & 3.90 & 1.88 & 3.40 & 3.97 \\
\hline Final $\mathrm{pH}$ & & 6.82 & 6.03 & 5.5 & 5.1 \\
\hline SME Product Mass & grams & & & & \\
\hline Time at Boiling (SME Cycle) & hours & 3.12 & 5.17 & & \\
\hline Total Time at Boiling (SRAT+SME) & hours & 18.63 & 20.60 & & \\
\hline Total Frit Addition & grams & 583.8 & 586.6 & 587.8 & 589 \\
\hline SME Sample 1 & grams & 142.77 & 143.95 & 157.09 & 136.4 \\
\hline SME Sample 2 & grams & 153.49 & 145.52 & 154.03 & 145.59 \\
\hline Total Dewater (SRAT/SME) & & 967.12 & 953.93 & 945.1 & 941 \\
\hline
\end{tabular}


WSRC-STI-2006-00109

Revision 0

Table A- 10. Mercury Results: SRAT and SME Products

\begin{tabular}{|c|c|c|c|c|c|c|c|c|}
\hline Run \# & Type & ADS Result & Slurry Basis & \multicolumn{2}{|c|}{ Solids Content (wt\%) } & $\mathrm{Hg}$ & \multicolumn{2}{|c|}{ Hg Results - Solid } \\
\hline & & $\mu \mathrm{g} / \mathrm{g}$ & $\mu \mathrm{g} / \mathrm{g}$ & Total & Calcine & $\begin{array}{c}\text { grams/k } \\
\mathrm{g}\end{array}$ & Total & $\bar{C}$ \\
\hline SB4-61 & SRAT Product & 94.3 & 943 & 26.4 & 16.9 & 0.943 & 0.357 & 0 \\
\hline SB4-61 & SRAT Product & 40.7 & 407 & 26.4 & 16.9 & 0.407 & 0.154 & \\
\hline SB4-61 & SME Product & 41.4 & 414 & 46.6 & 38.8 & 0.414 & 0.089 & U \\
\hline SB4-61 & SME Product & 40.4 & 404 & 46.6 & 38.8 & 0.404 & 0.087 & $\overline{0}$ \\
\hline SB4-62 & SRAT Product & 89.5 & 895 & 26.5 & 16.4 & 0.895 & 0.338 & $\mathrm{c}$ \\
\hline SB4-62 & SRAT Product & 90.5 & 905 & 26.5 & 16.6 & 0.905 & 0.342 & 0 \\
\hline SB4-62 & SME Product & 75.5 & 755 & 47.6 & 39.1 & 0.755 & 0.159 & 0 \\
\hline SB4-62 & SME Product & 104 & 1040 & 47.6 & 39.1 & 1.04 & 0.218 & $\overline{0}$ \\
\hline SB4-63 & SRAT Product & 64 & 640 & 26.4 & 16.2 & 0.64 & 0.242 & 0 \\
\hline SB4-63 & SRAT Product & 65.2 & 652 & 26.4 & 16.1 & 0.652 & 0.247 & 0 \\
\hline SB4-63 & SME Product & 44.8 & 448 & 47.1 & 38.3 & 0.448 & 0.095 & 0 \\
\hline SB4-63 & SME Product & 46.3 & 463 & 46.5 & 38.3 & 0.463 & 0.100 & 0 \\
\hline SB4-64 & SRAT Product & 100 & 1000 & 26.2 & 15.9 & 1 & 0.382 & 0 \\
\hline SB4-64 & SRAT Product & 102 & 1020 & 26.3 & 15.9 & 1.02 & 0.388 & 0 \\
\hline SB4-64 & SME Product & 65.6 & 656 & 47.2 & 38.3 & 0.656 & 0.139 & $\overline{0}$ \\
\hline SB4-64 & SME Product & 64 & 640 & 47 & 38.1 & 0.64 & 0.136 & 0 \\
\hline
\end{tabular}

Table A- 11. Mercury Results: Process Samples

\begin{tabular}{|l|c|c|c|c|}
\hline & $\mathbf{1 3 0 \%}$ & $\mathbf{1 5 0} \%$ & $\mathbf{1 6 0 \%}$ & $\mathbf{1 7 0 \%}$ \\
\hline Feed & 1736 & 1736 & 1736 & 1736 \\
\hline H2 Onset & & 2620 & 767 & 1520 \\
\hline H2 Peak & & 1590 & 757 & 2540 \\
\hline $\begin{array}{l}\text { SRAT } \\
\text { Product }\end{array}$ & 650 & 900 & 646 & 1010 \\
\hline SME Product & 409 & 898 & 456 & 648 \\
\hline
\end{tabular}




\section{Appendix B. Sample/Run Results: Graphical Presentations}

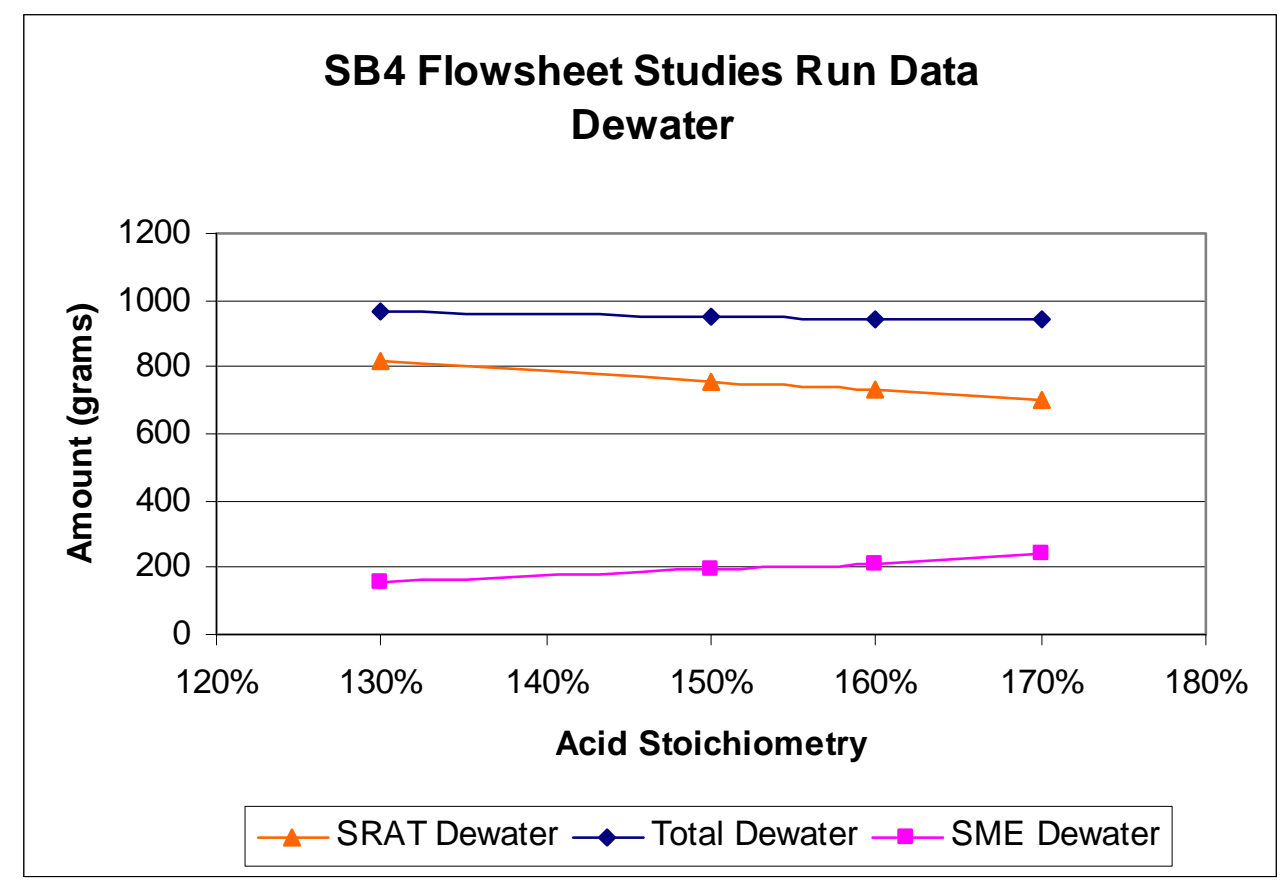

Figure B- 1. Dewater Amounts

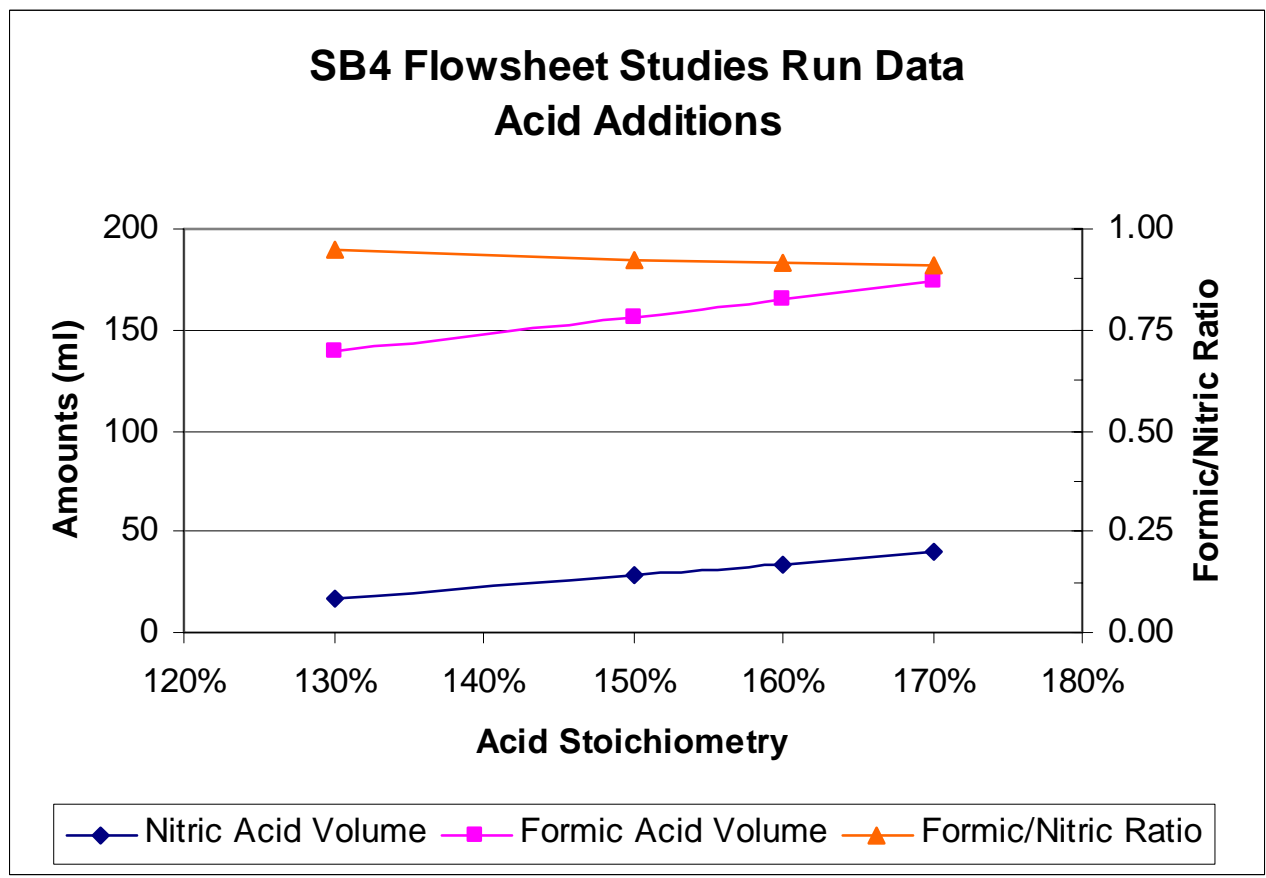

Figure B- 2. Acid Addition Volumes and Ratios 
WSRC-STI-2006-00109

Revision 0

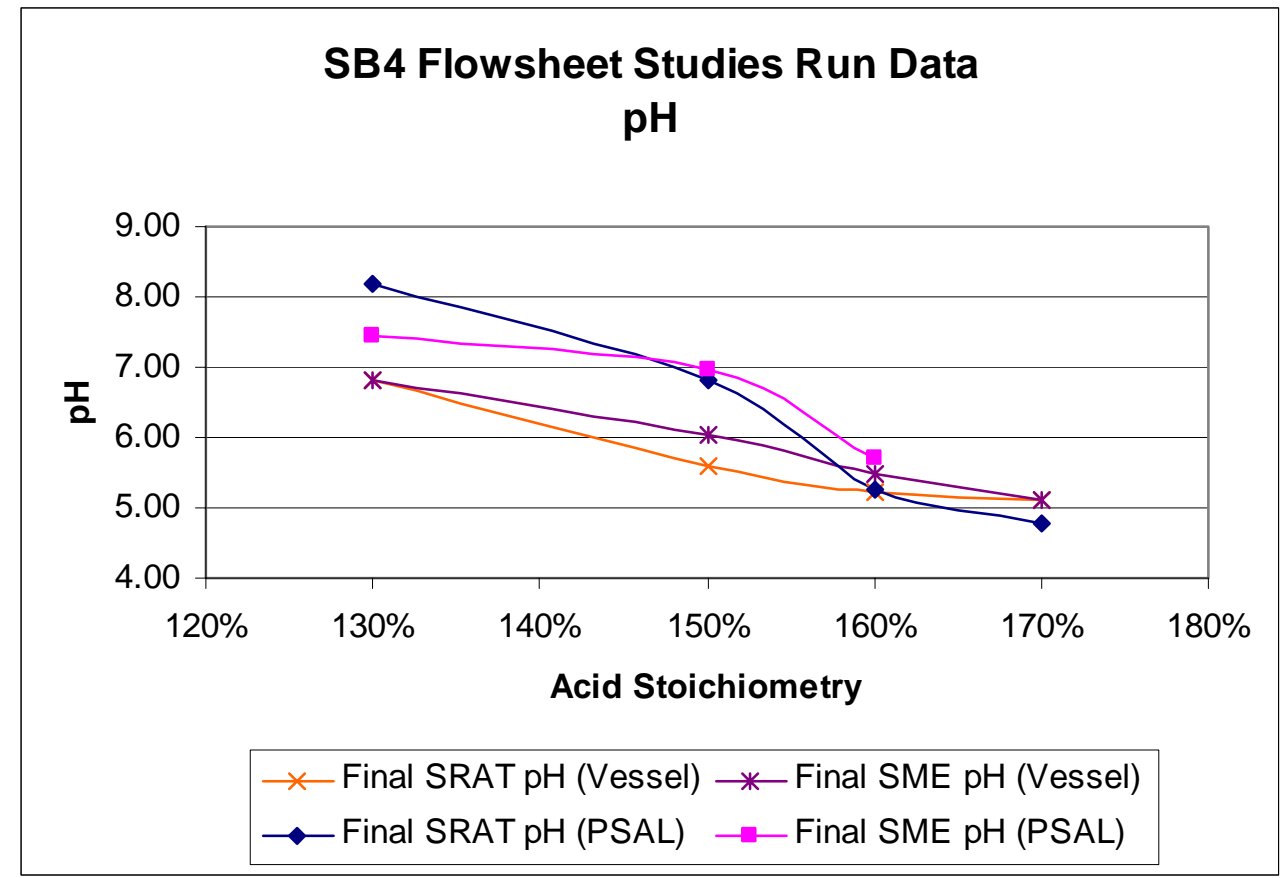

Figure B- 3. Final SRAT and SME pH

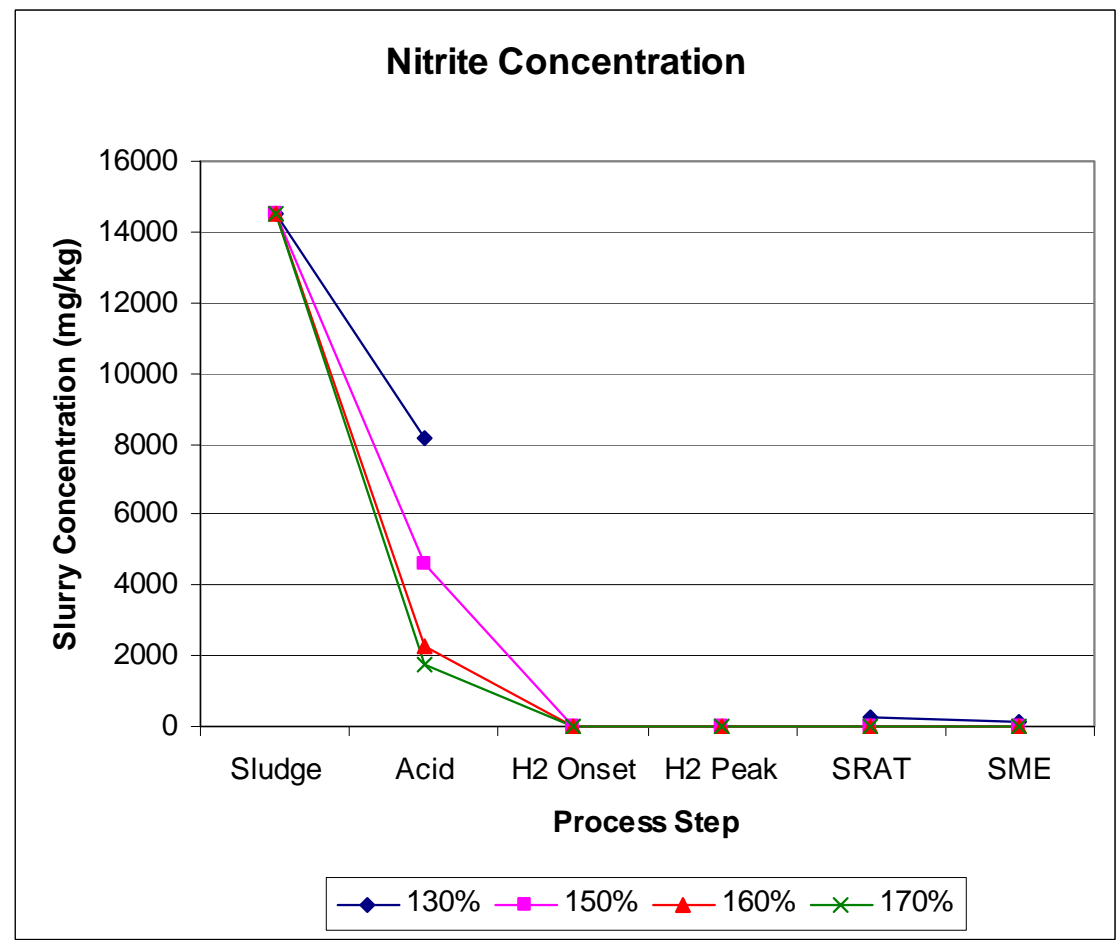

Figure B- 4. Nitrite Concentration Profile 
WSRC-STI-2006-00109

Revision 0

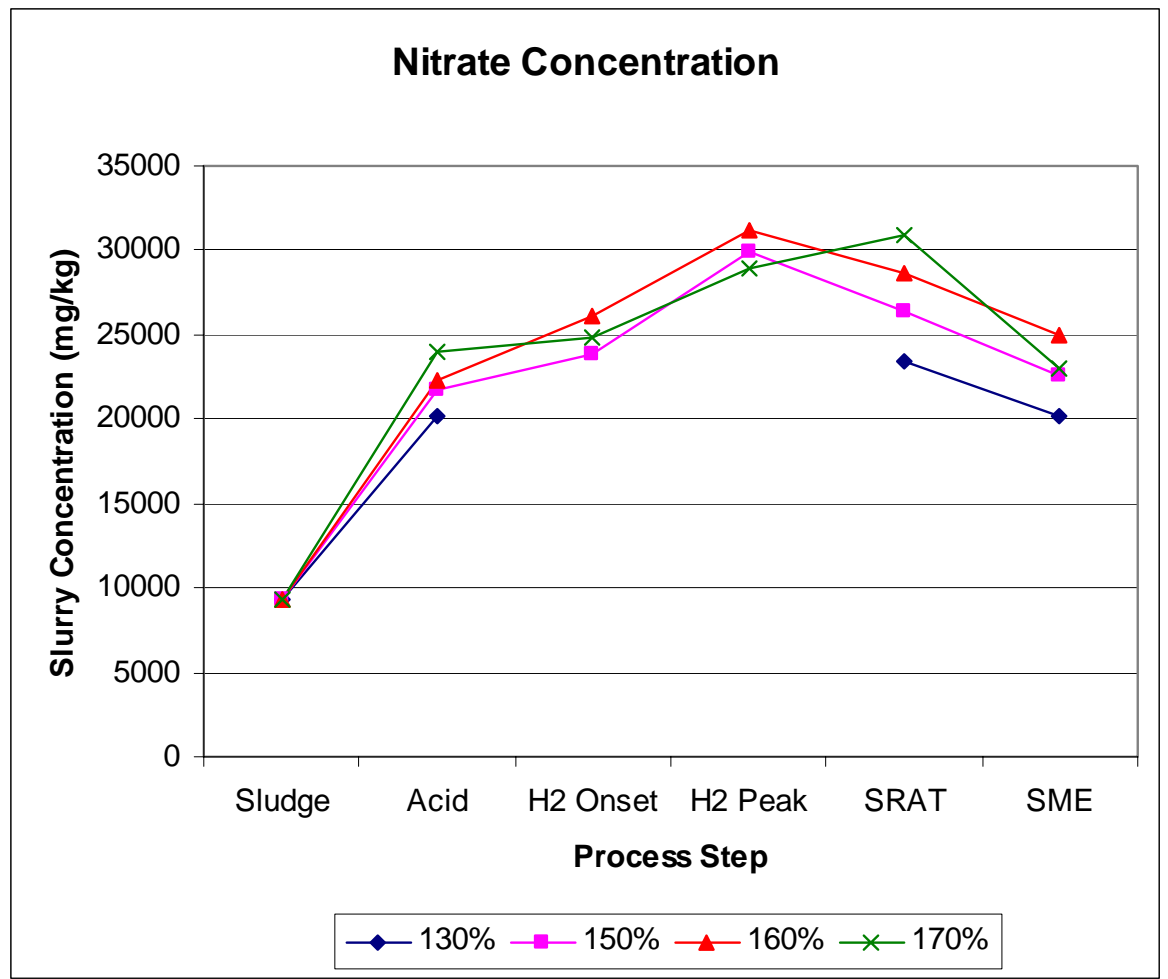

Figure B- 5. Nitrate Concentration Profile

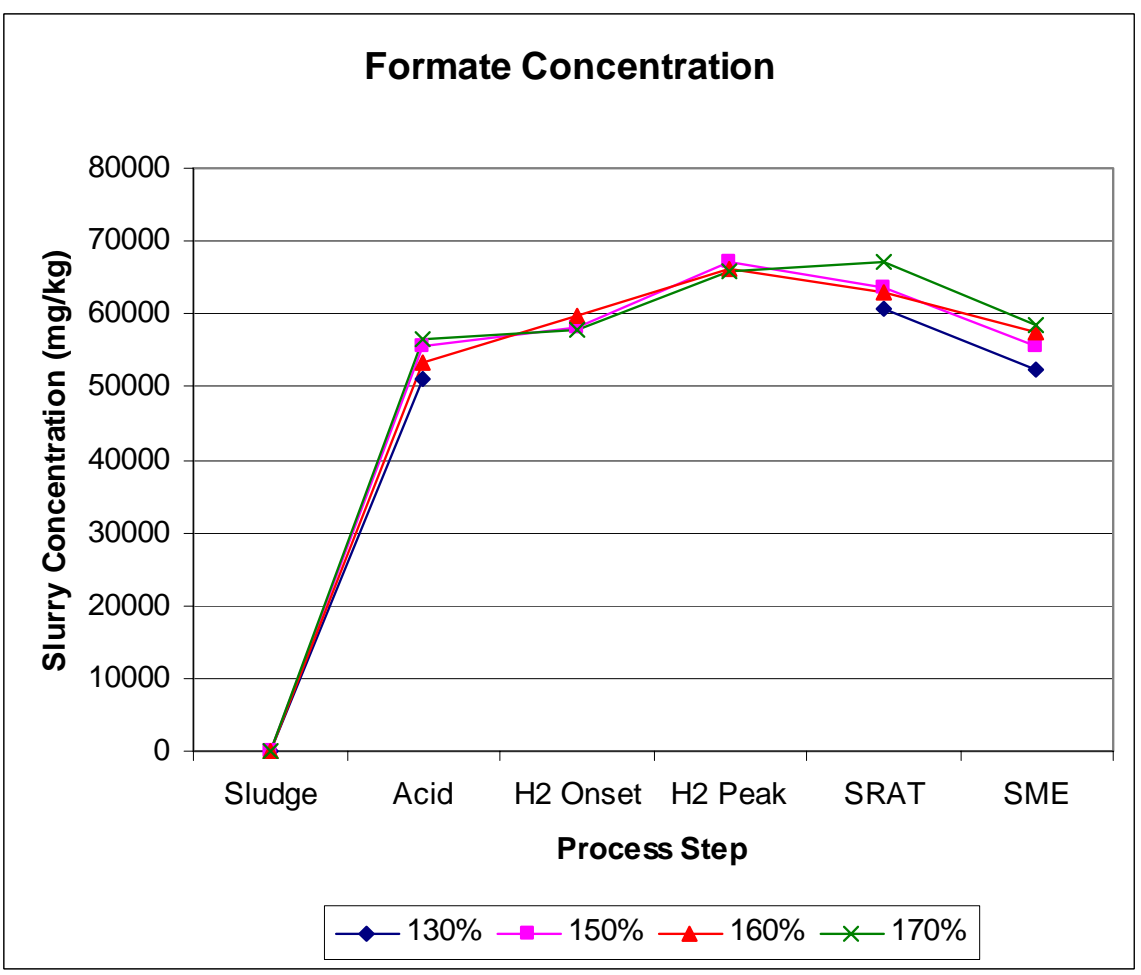

Figure B- 6. Formate Concentration Profile 
WSRC-STI-2006-00109

Revision 0

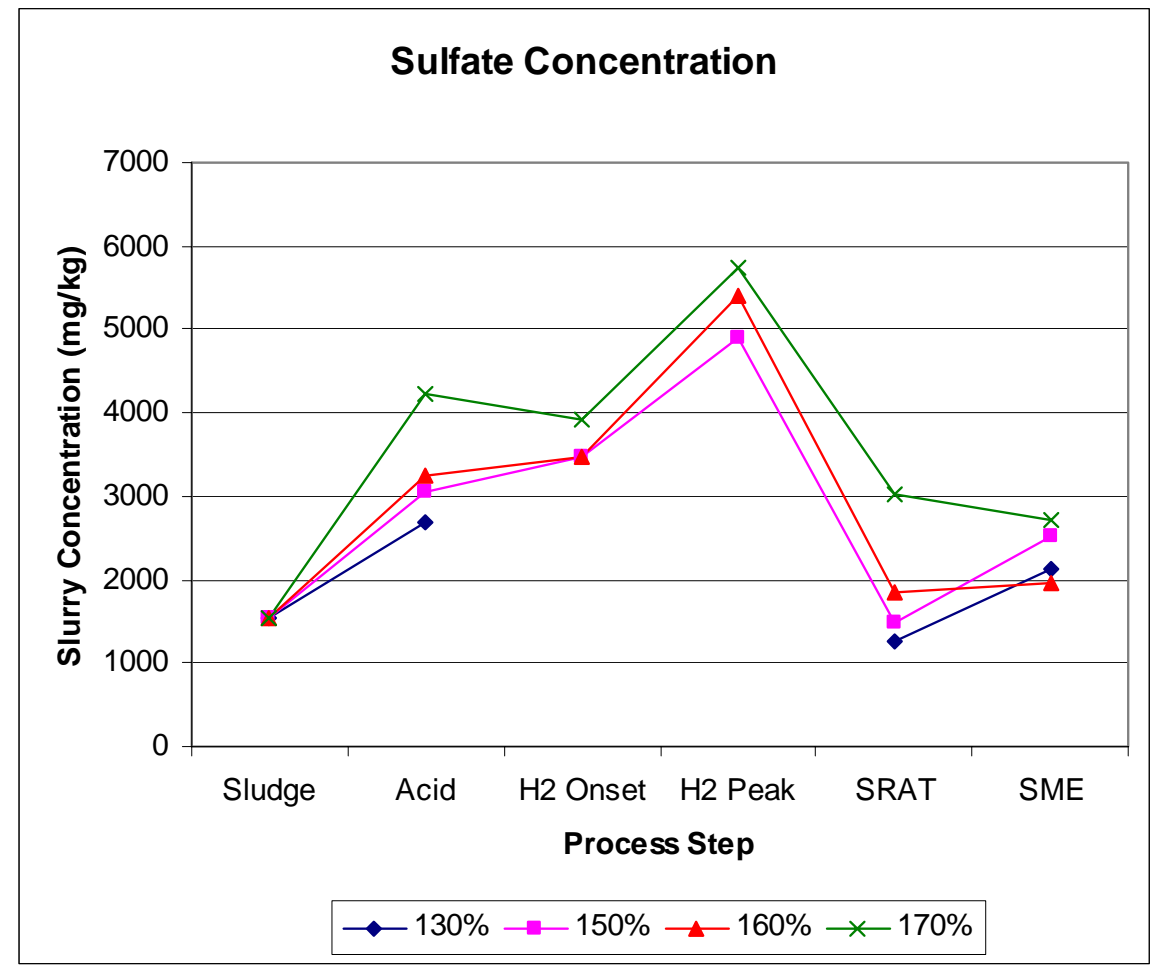

Figure B- 7. Sulfate Concentration Profile

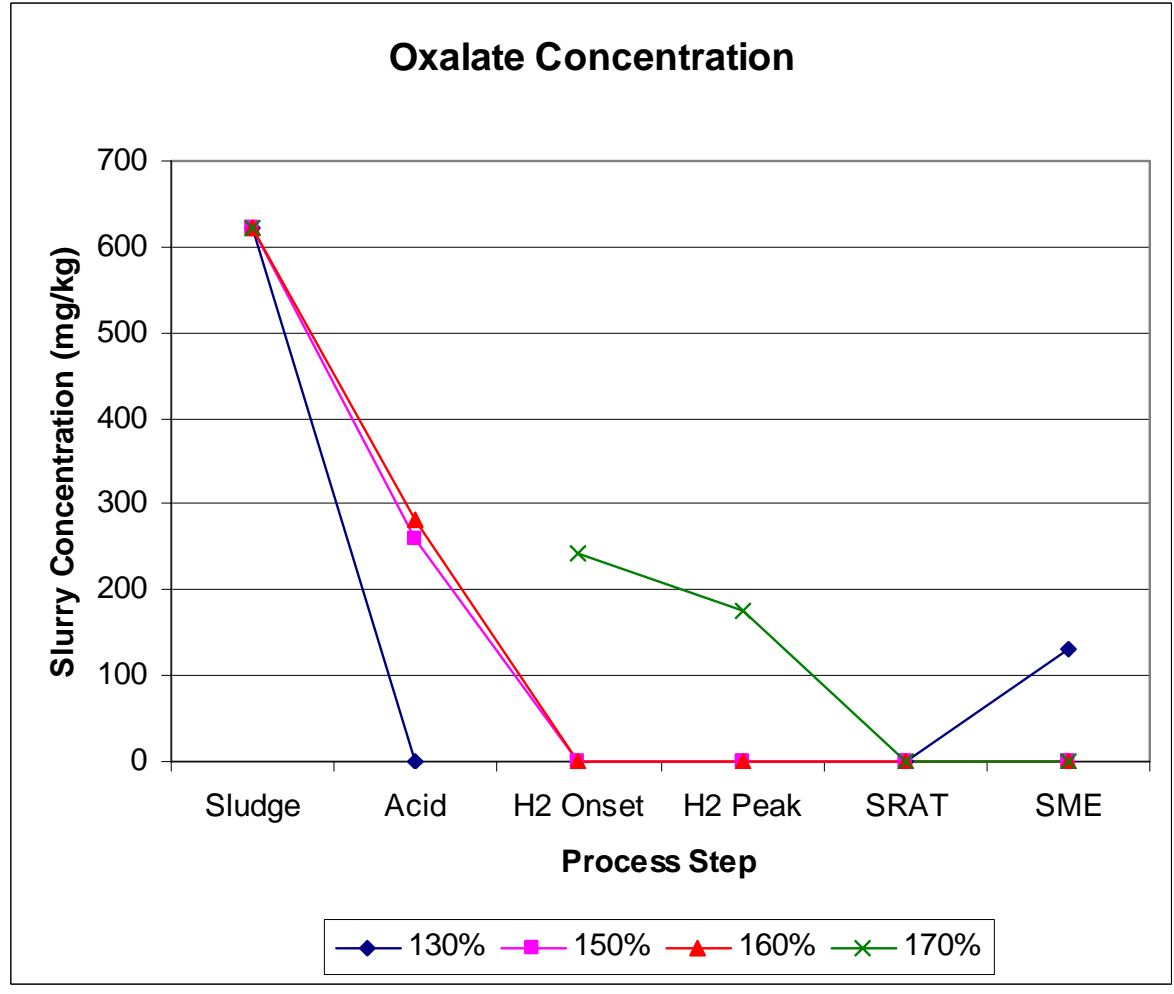

Figure B- 8. Oxalate Concentration Profile 
WSRC-STI-2006-00109

Revision 0

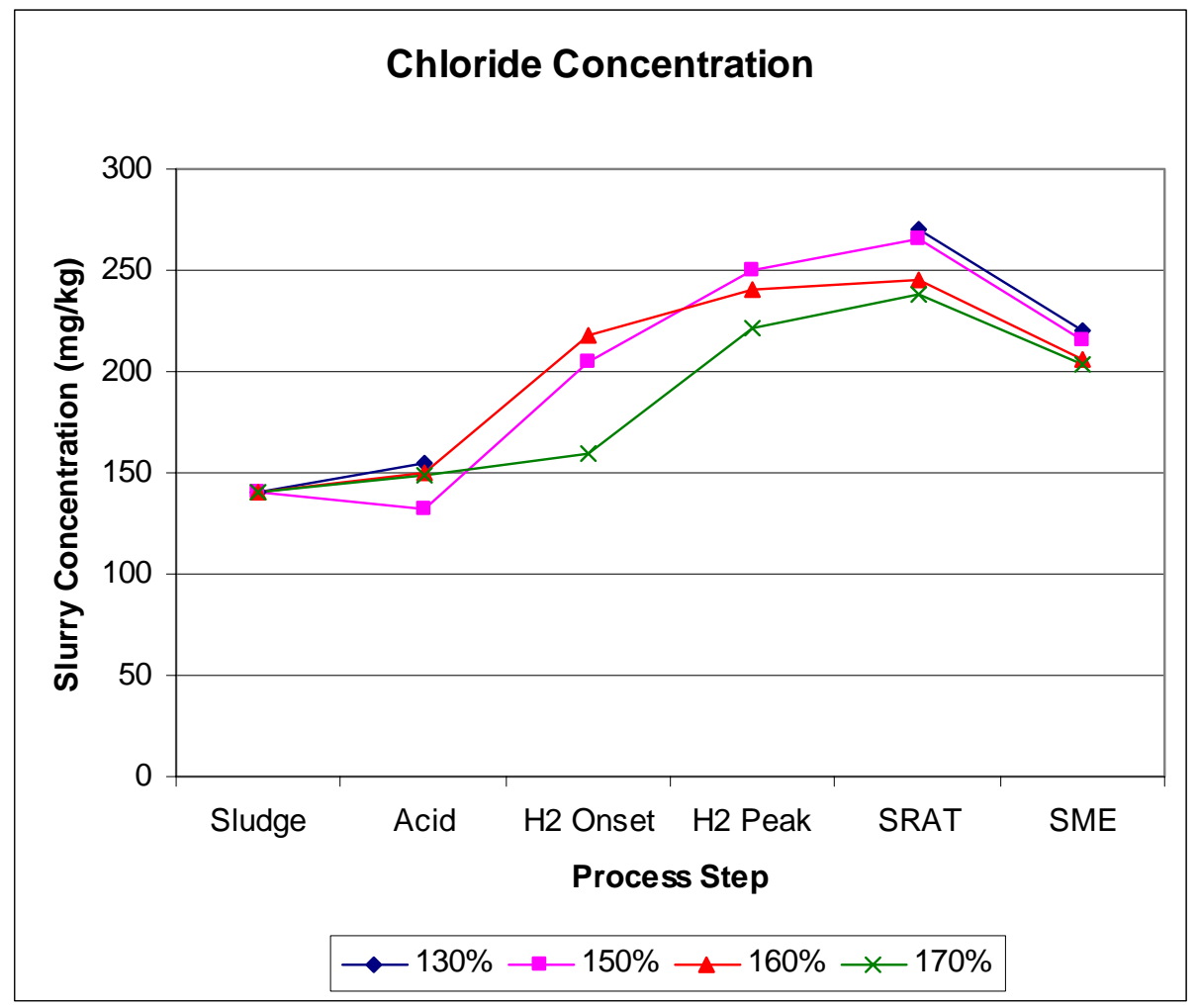

Figure B- 9. Chloride Concentration Profile

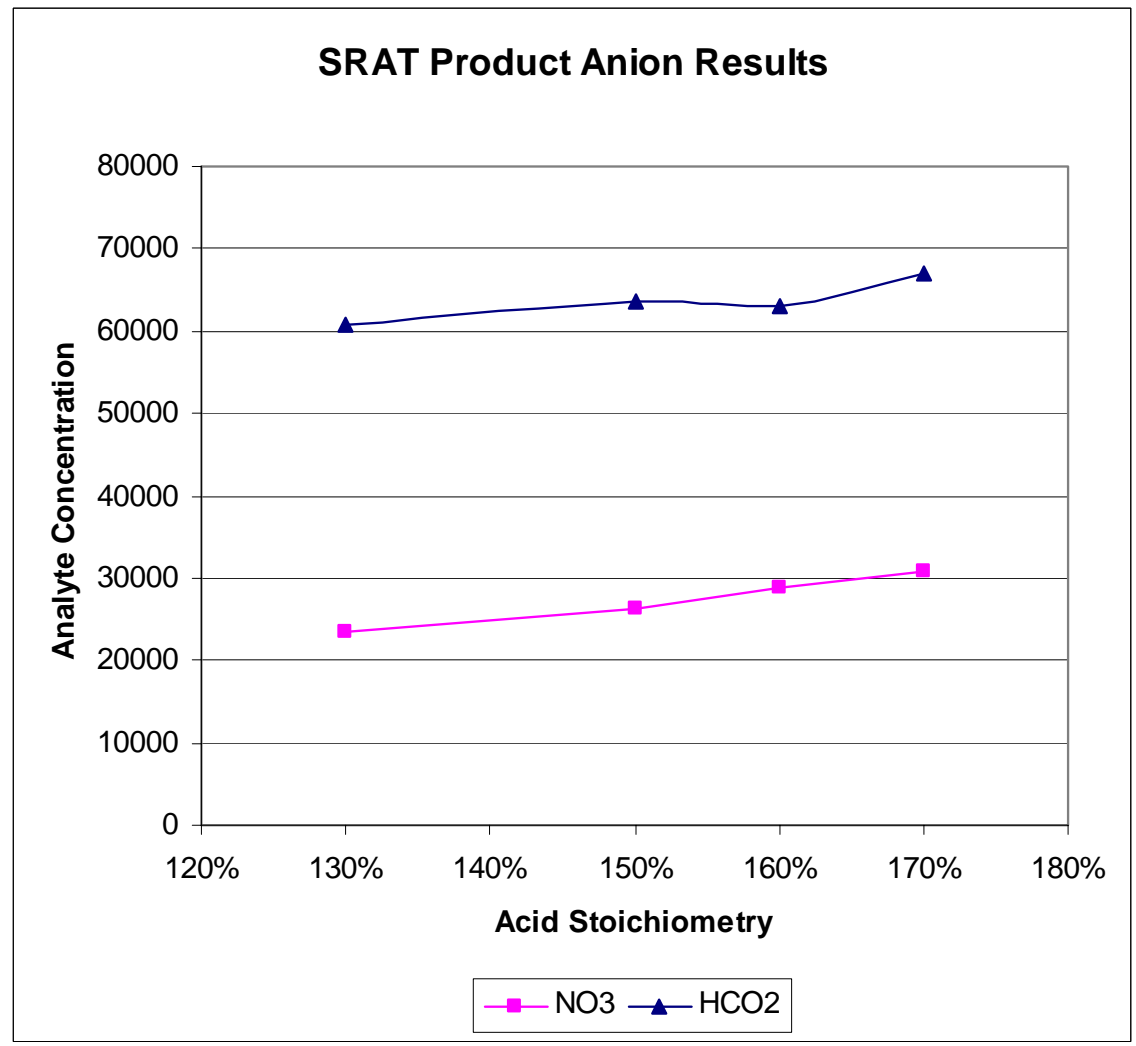

Figure B- 10. Nitrate and Formate Concentration versus Acid Stoichiometry 


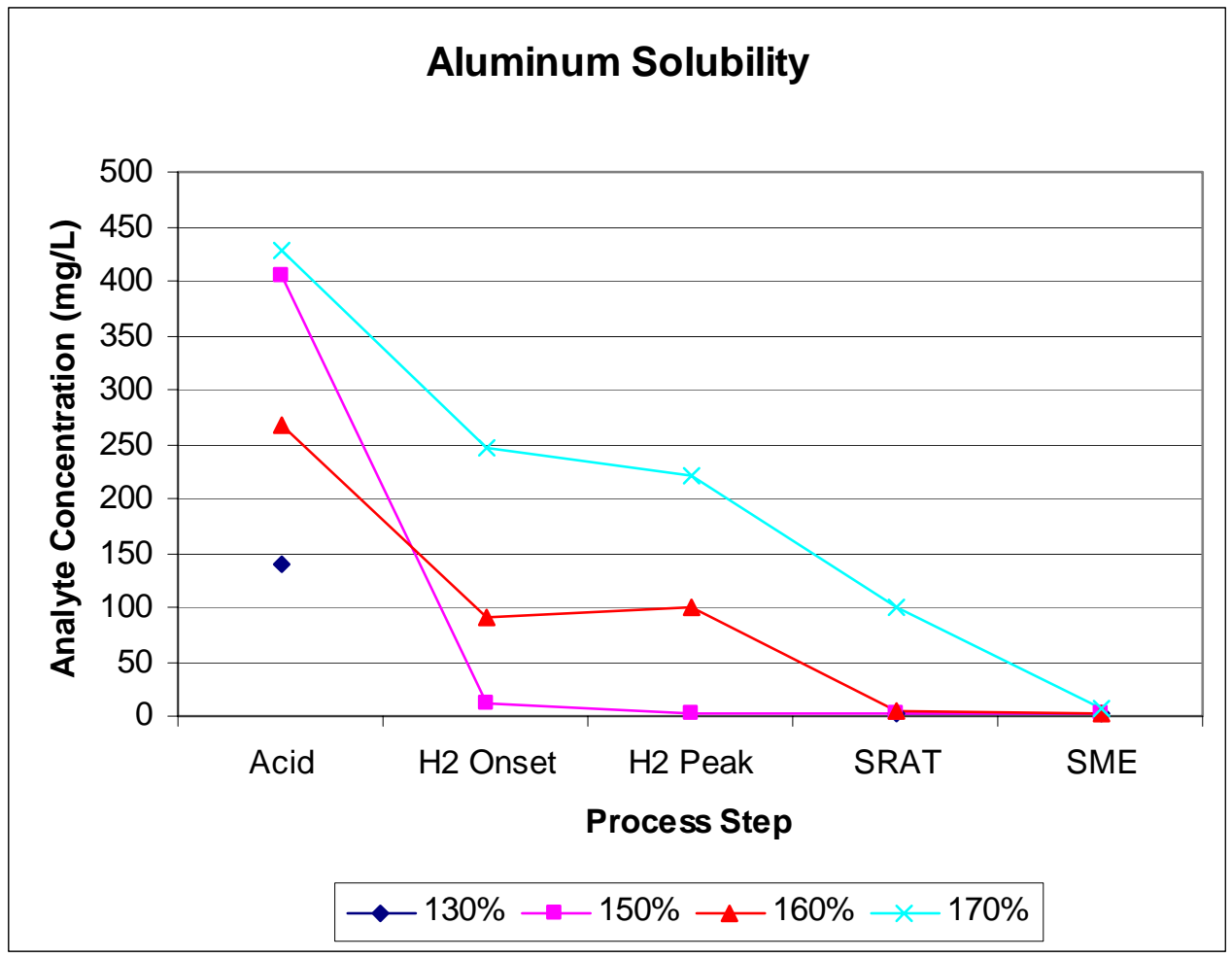

Figure B- 11. Aluminum Solubility

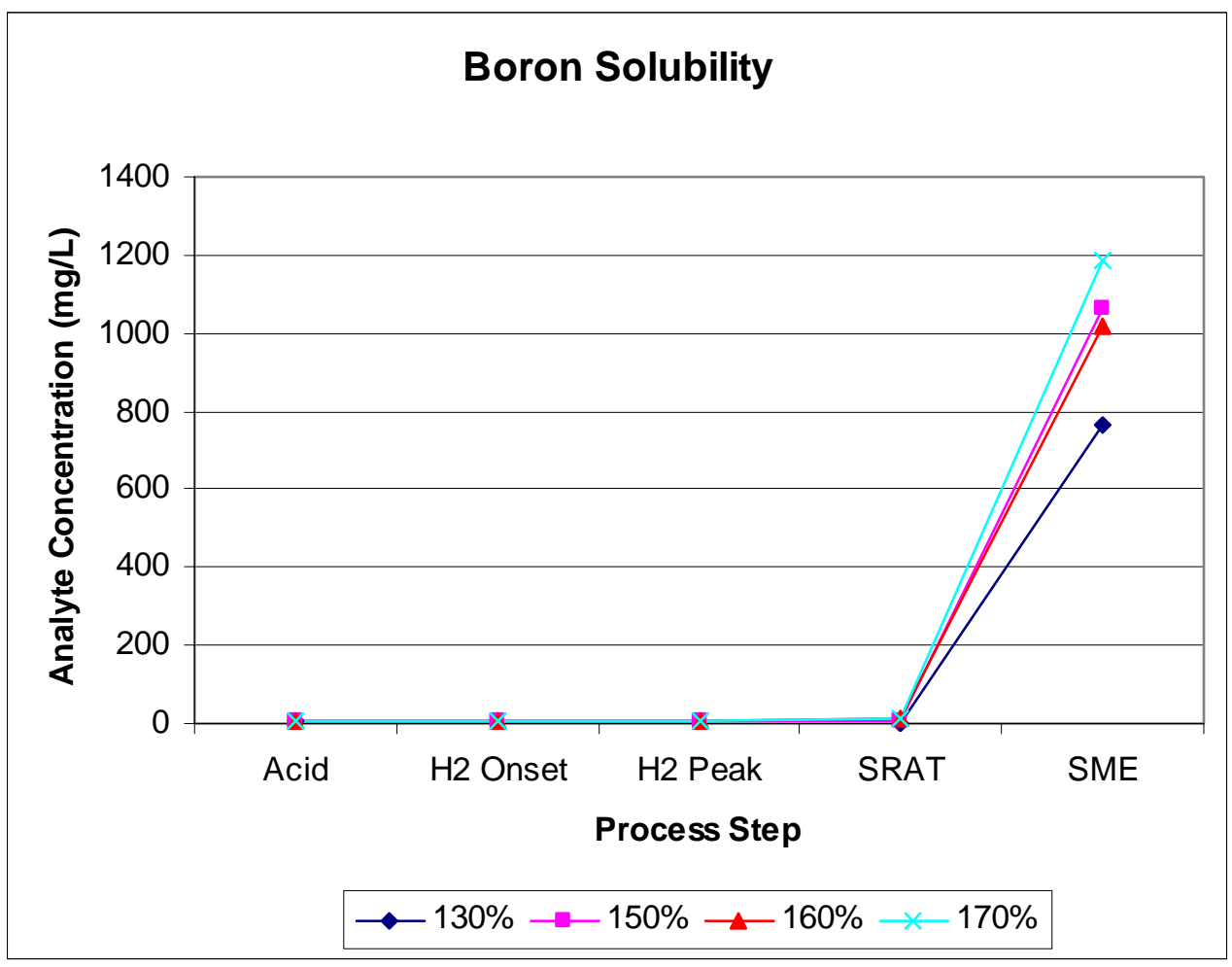

Figure B- 12. Boron Solubility 


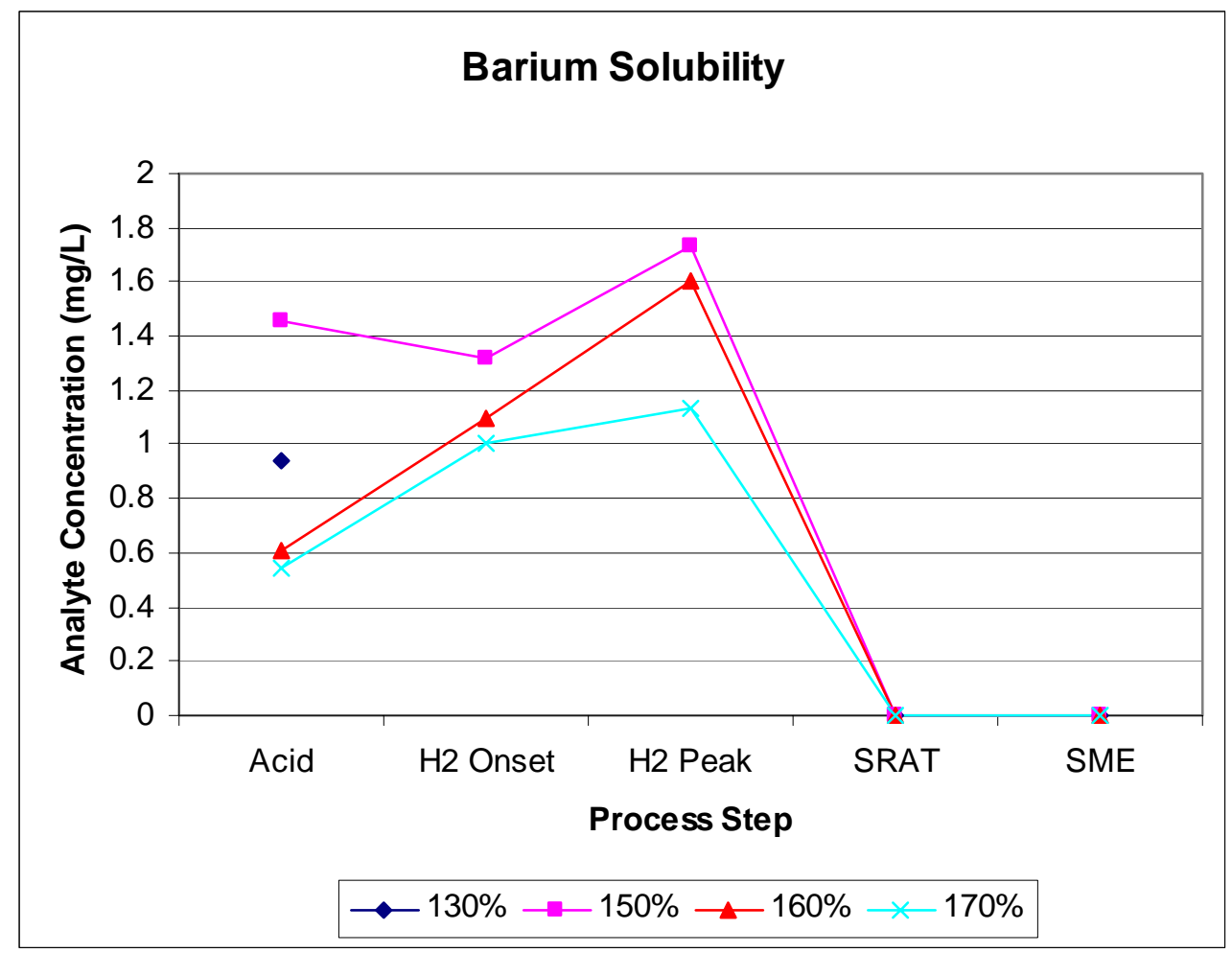

Figure B- 13. Barium Solubility

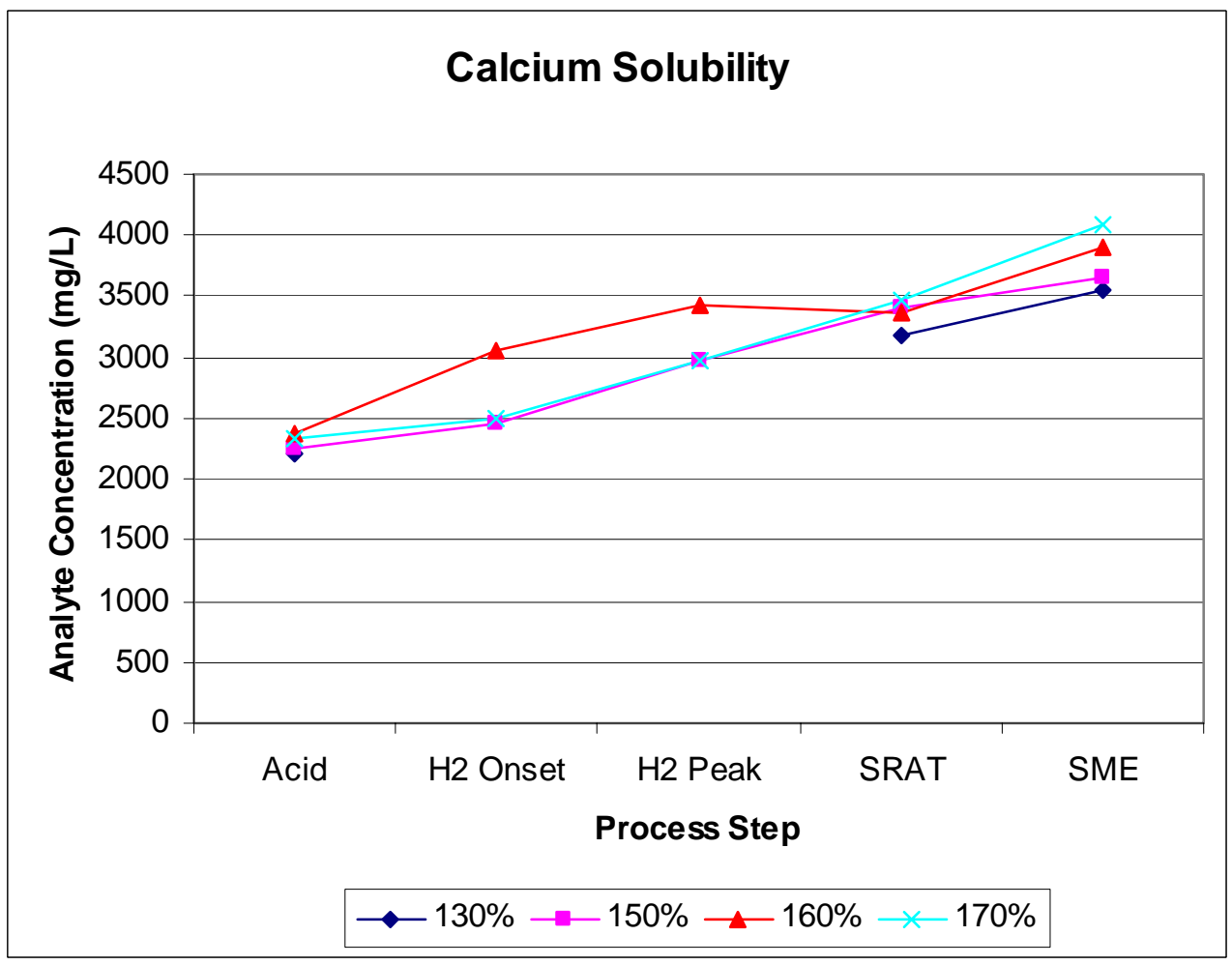

Figure B- 14. Calcium Solubility 


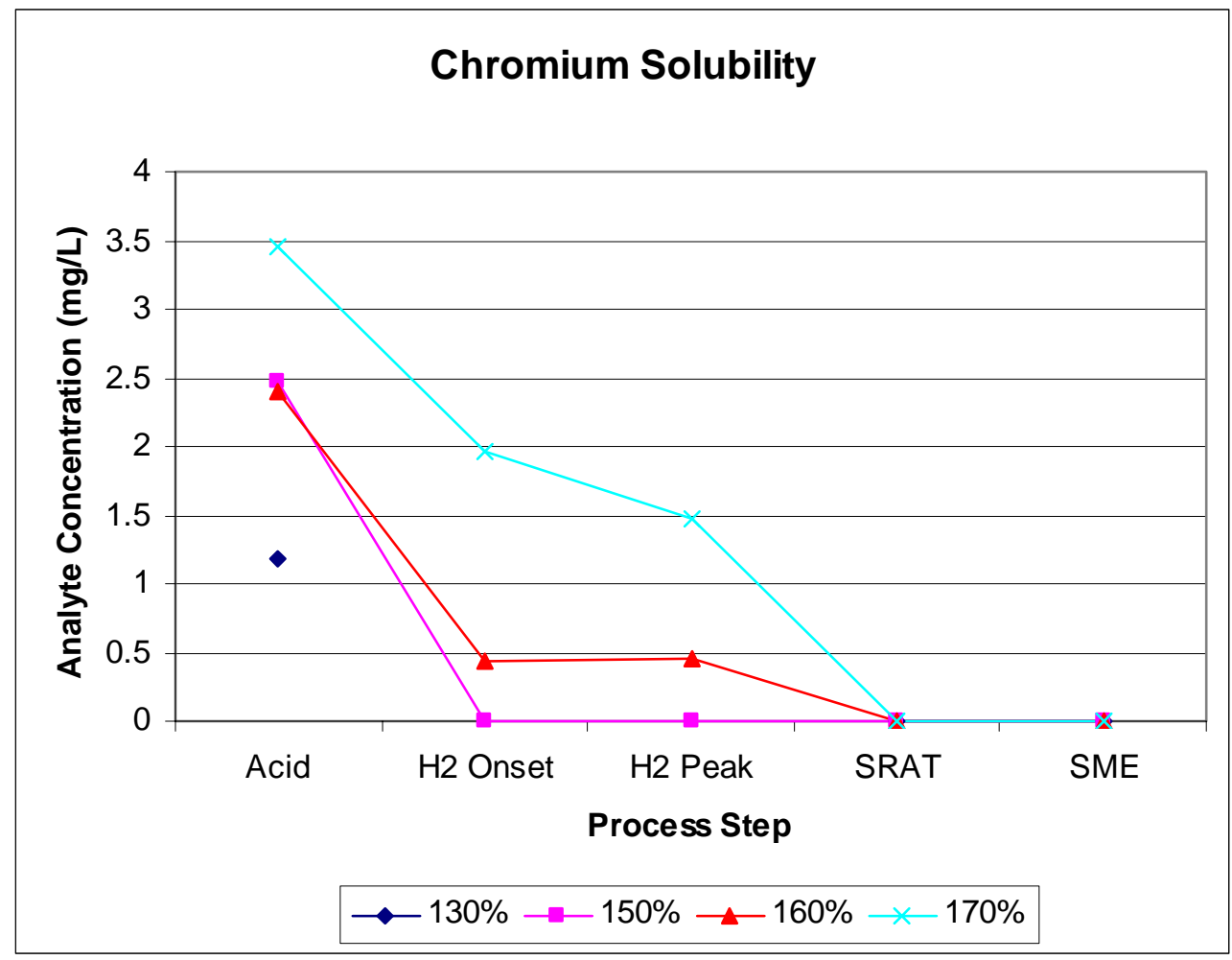

Figure B- 15. Chromium Solubility

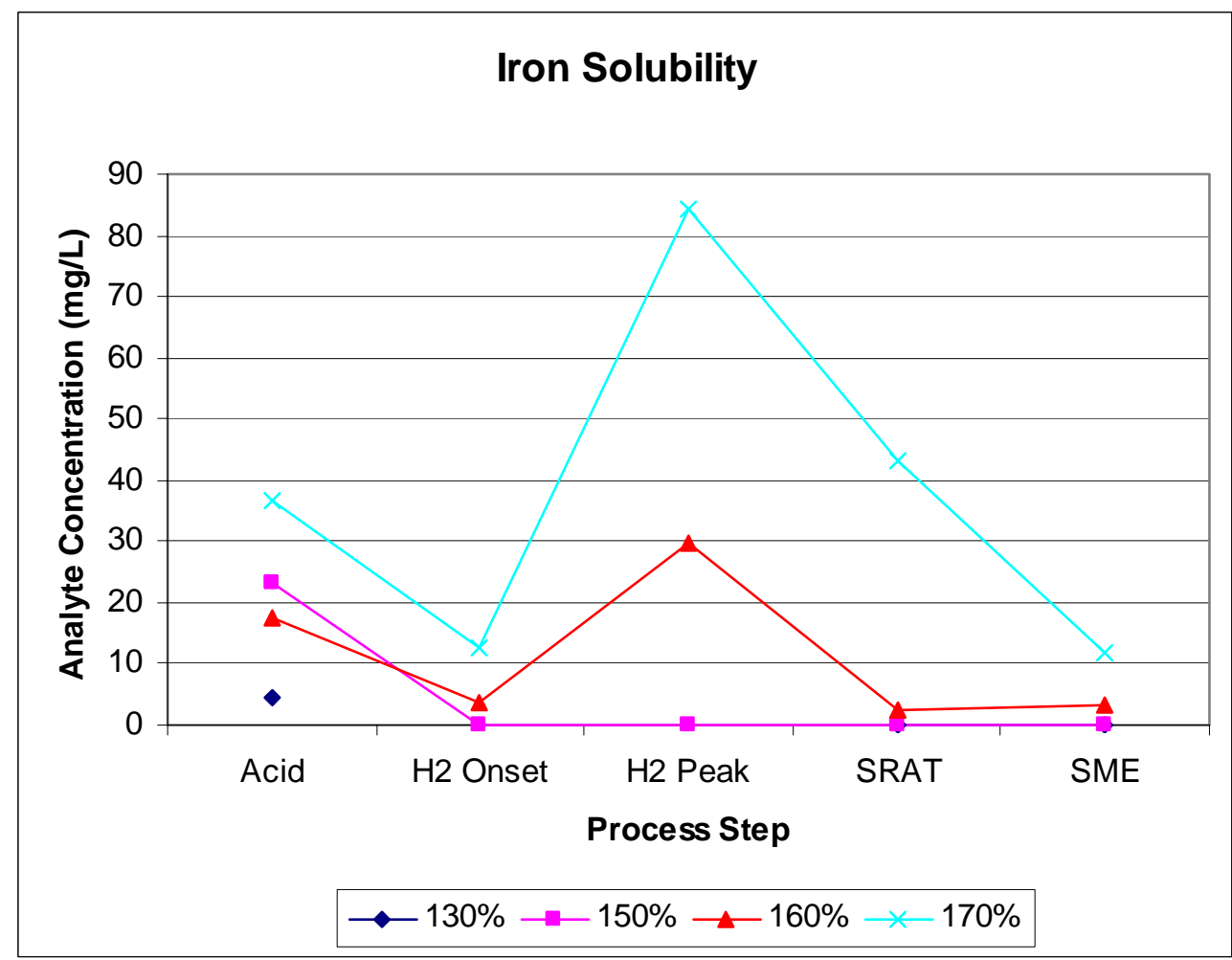

Figure B- 16. Iron Solubility 


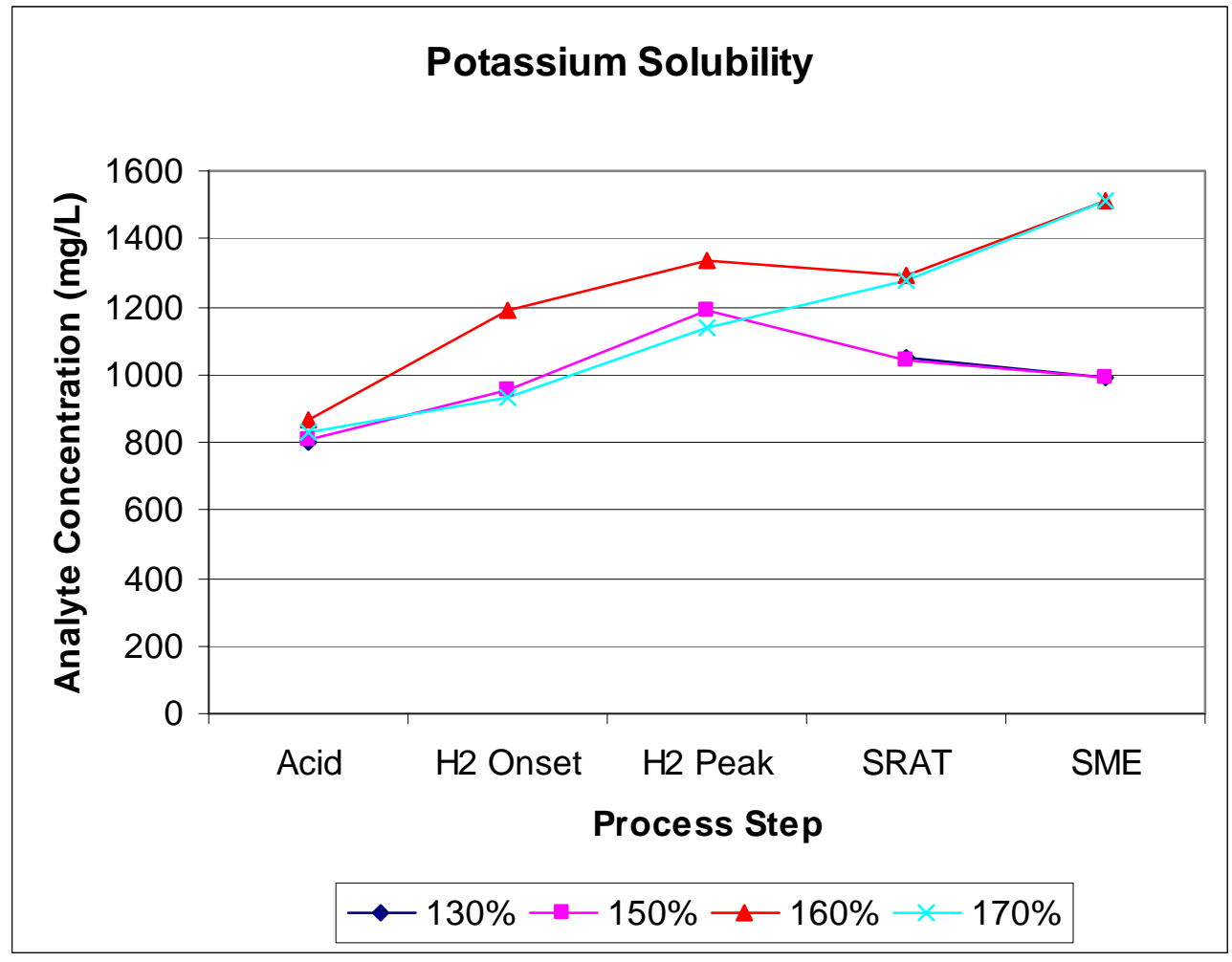

Figure B- 17. Potassium Solubility

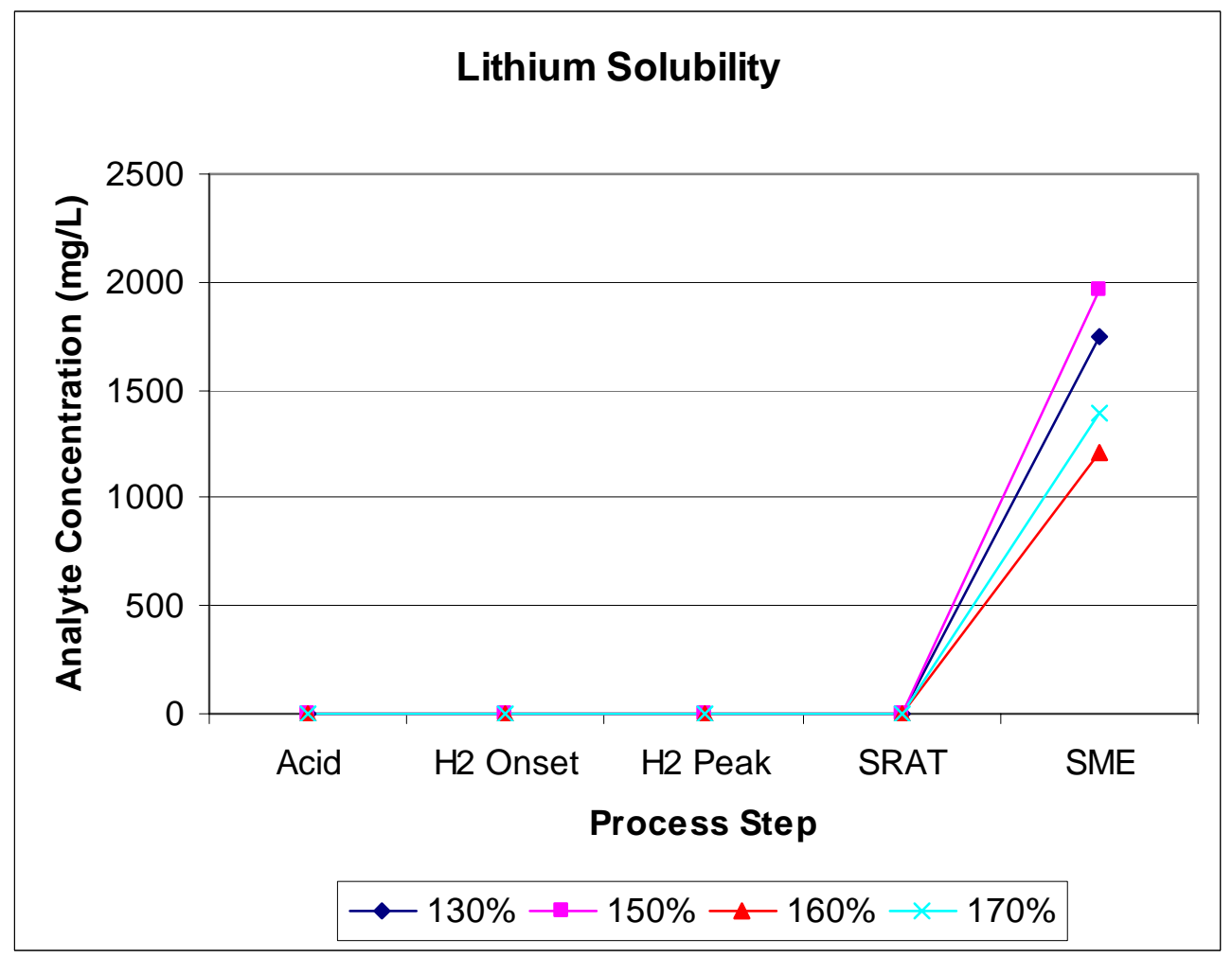

Figure B- 18. Lithium Solubility 


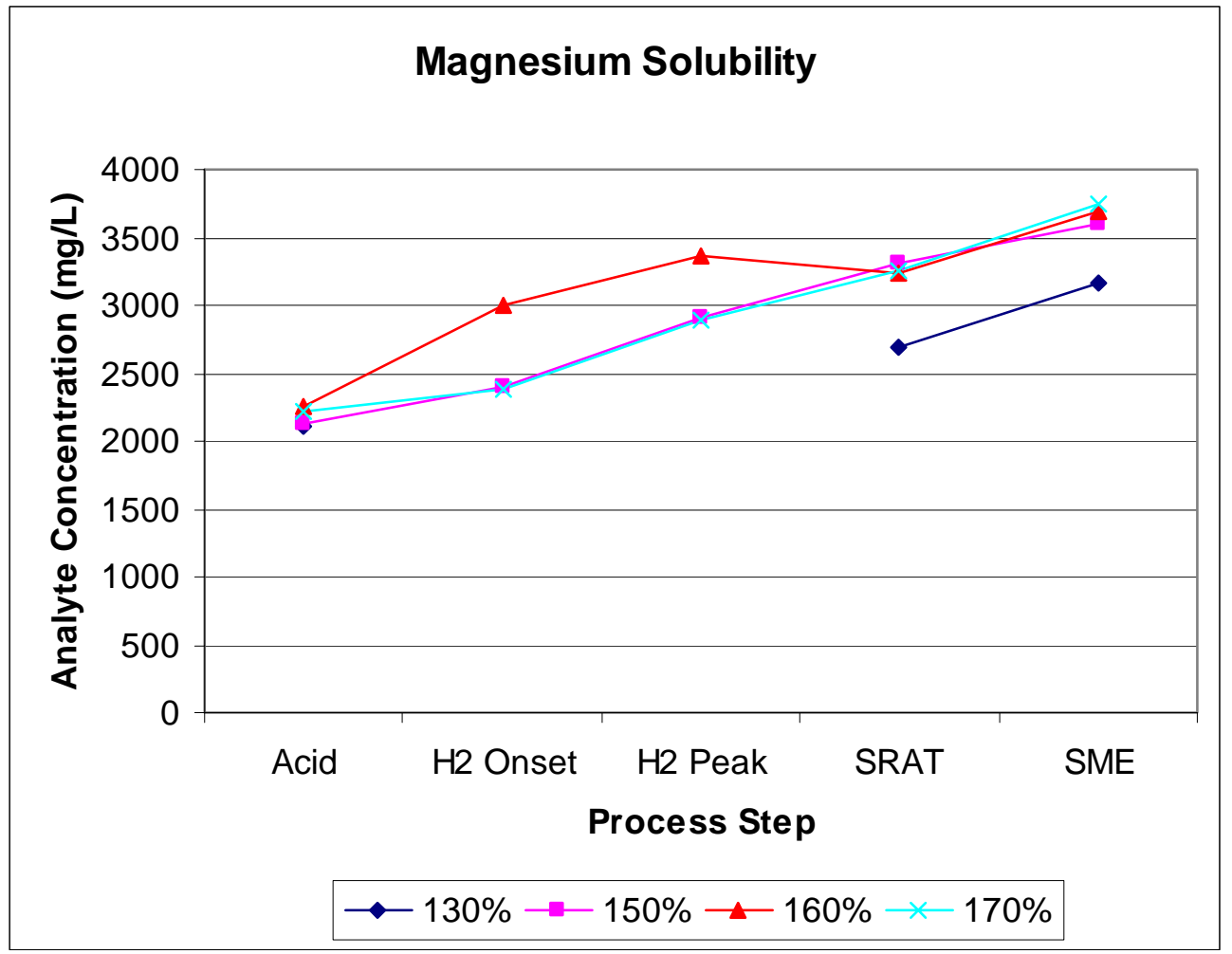

Figure B- 19. Magnesium Solubility

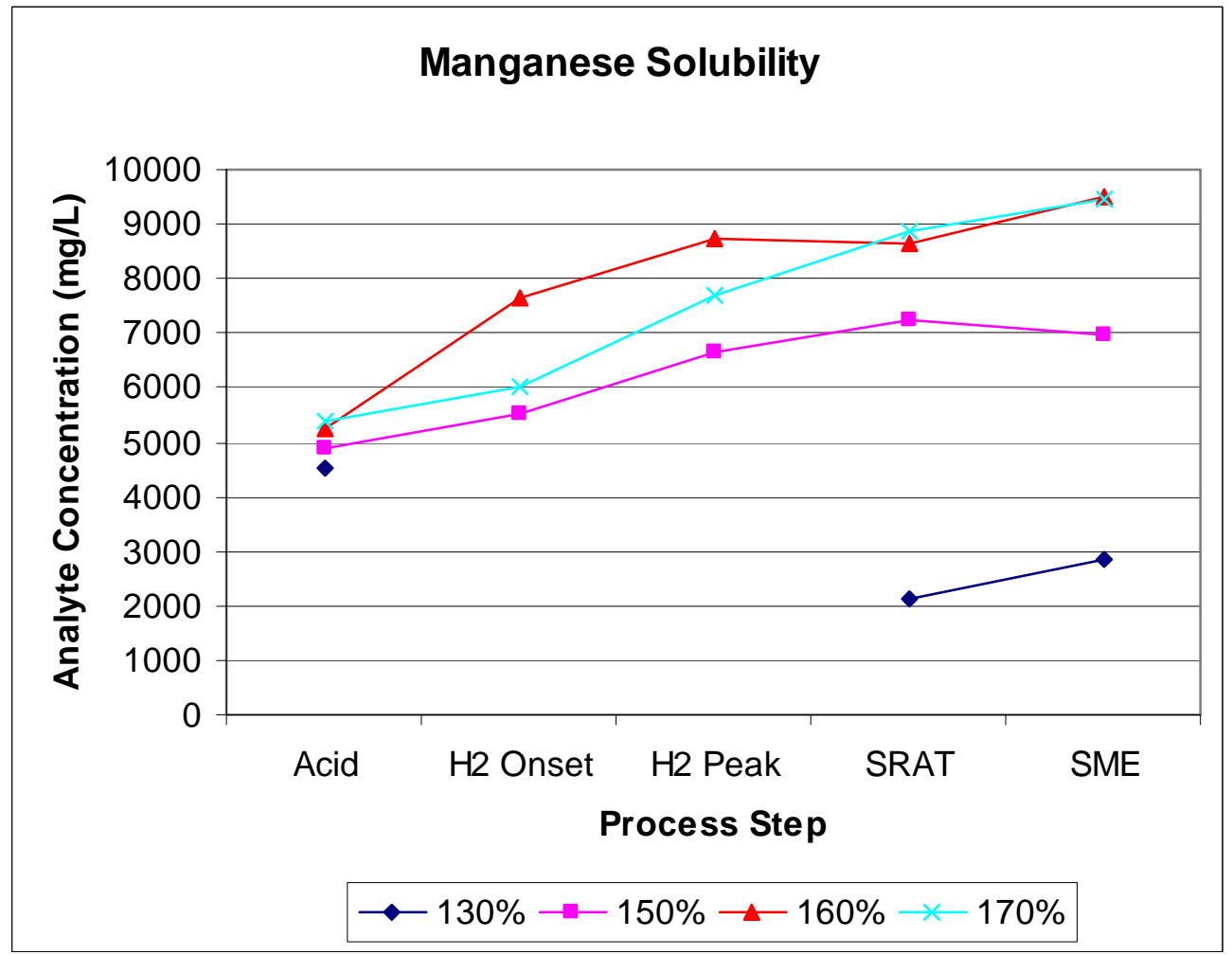

Figure B- 20. Manganese Solubility 


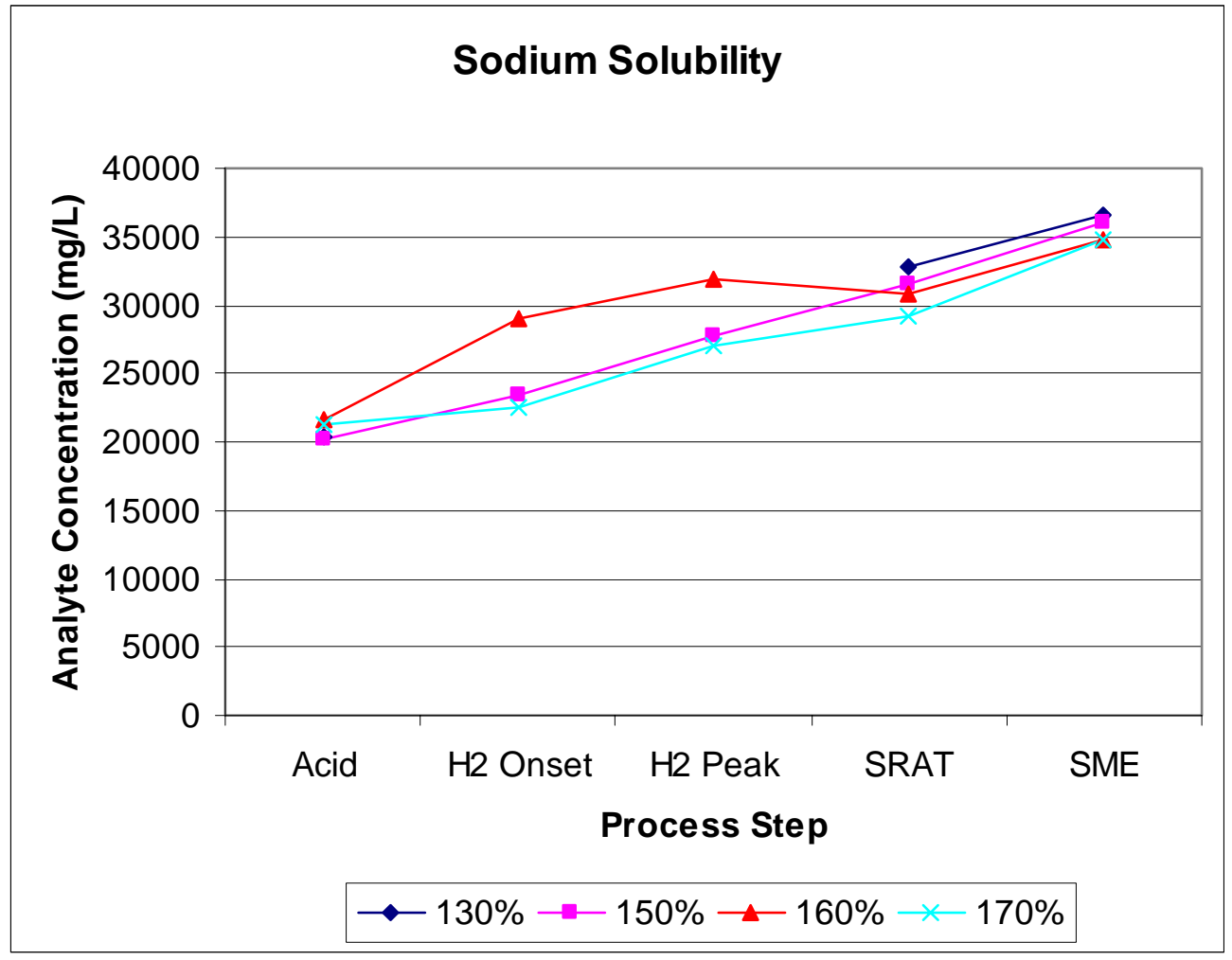

Figure B- 21. Sodium Solubility

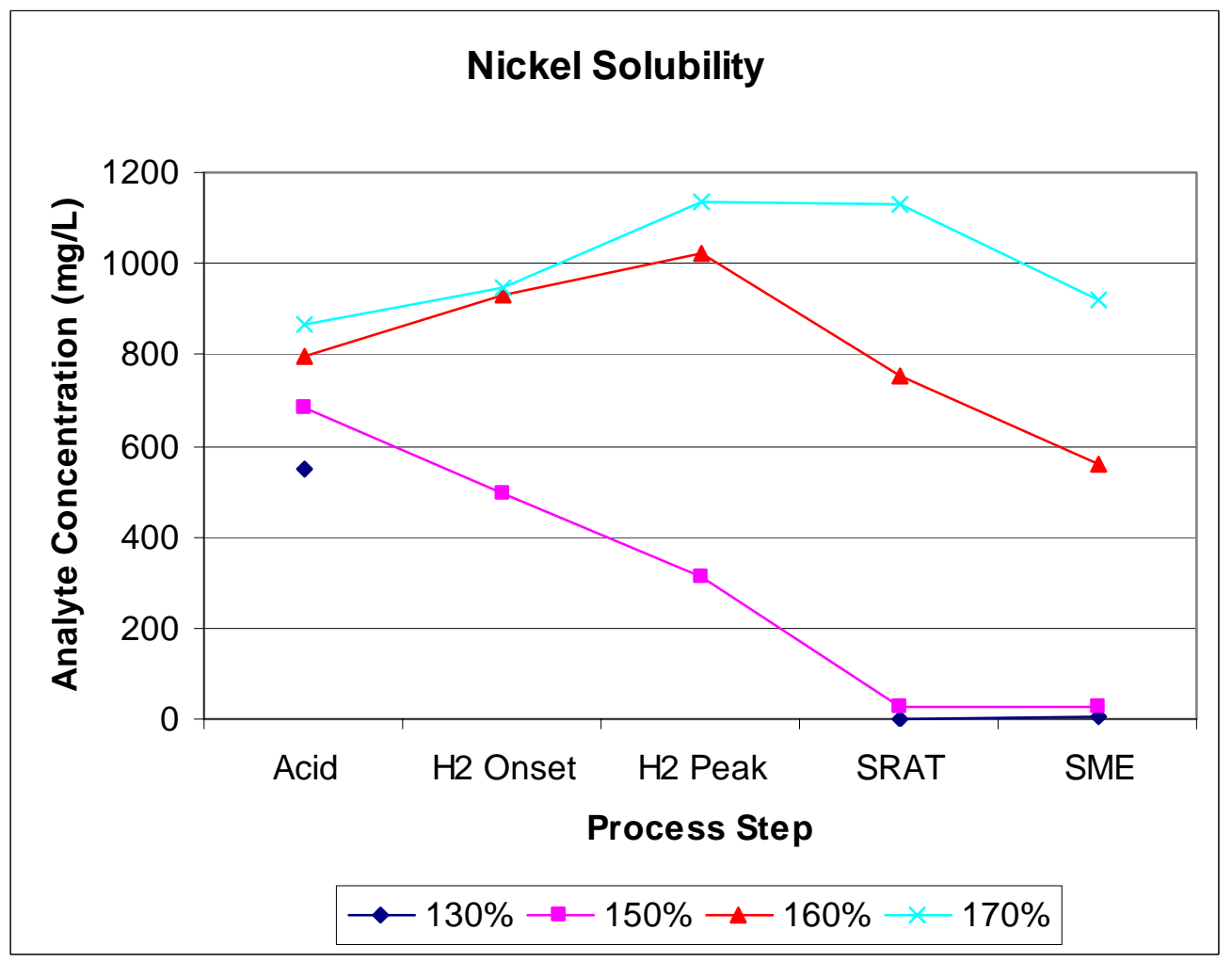

Figure B- 22. Nickel Solubility 


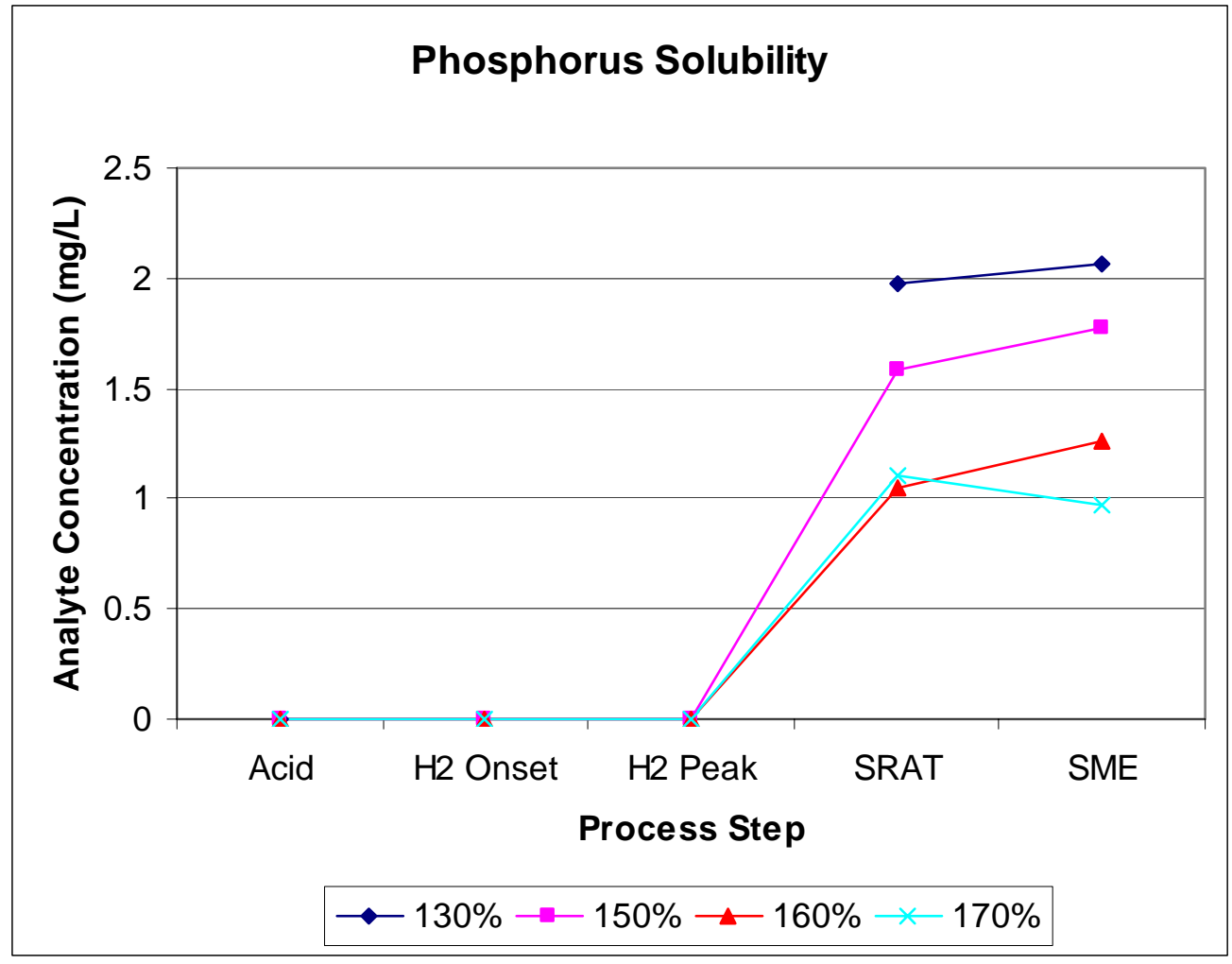

Figure B- 23. Phosphorus Solubility

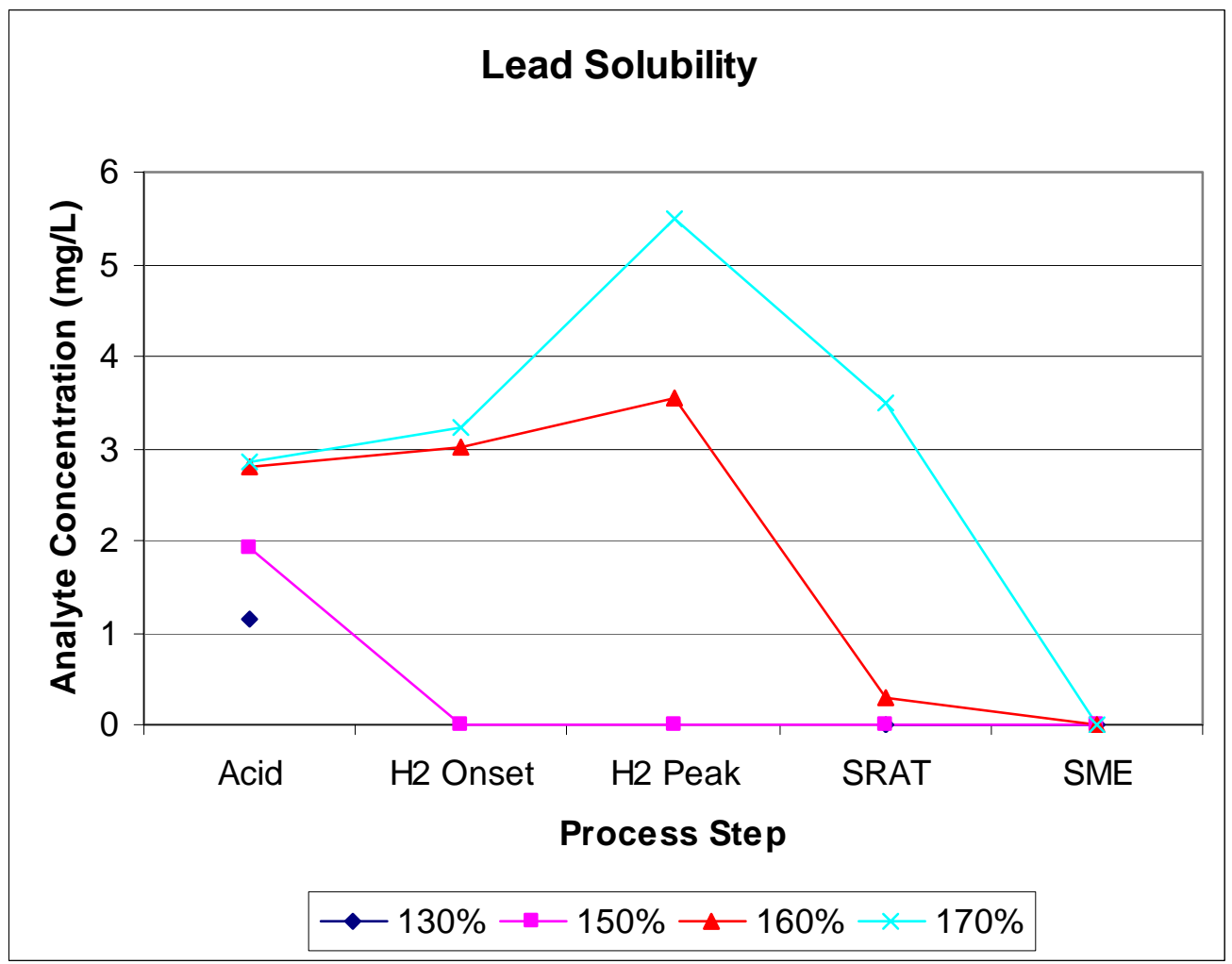

Figure B- 24. Lead Solubility 


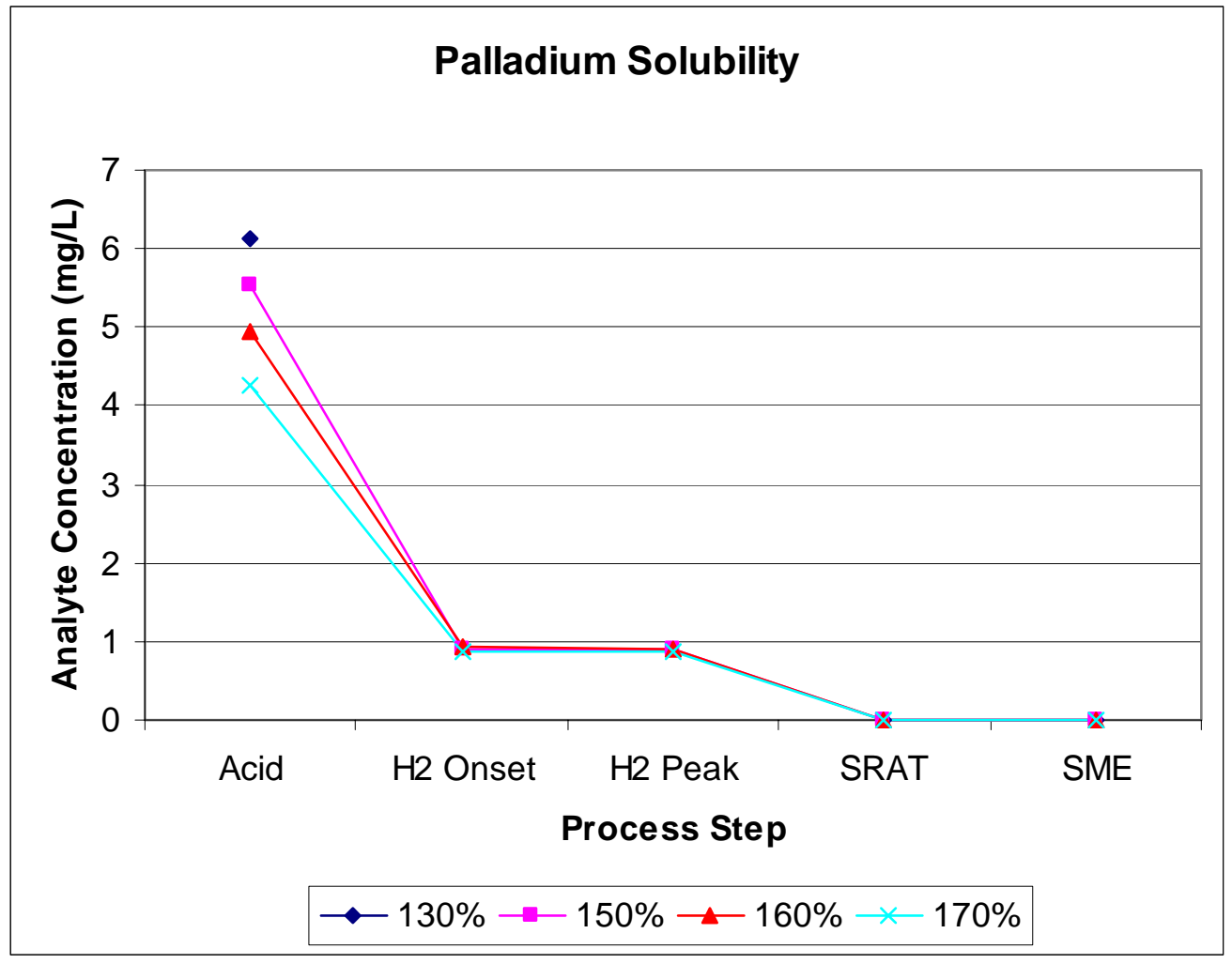

Figure B- 25. Palladium Solubility

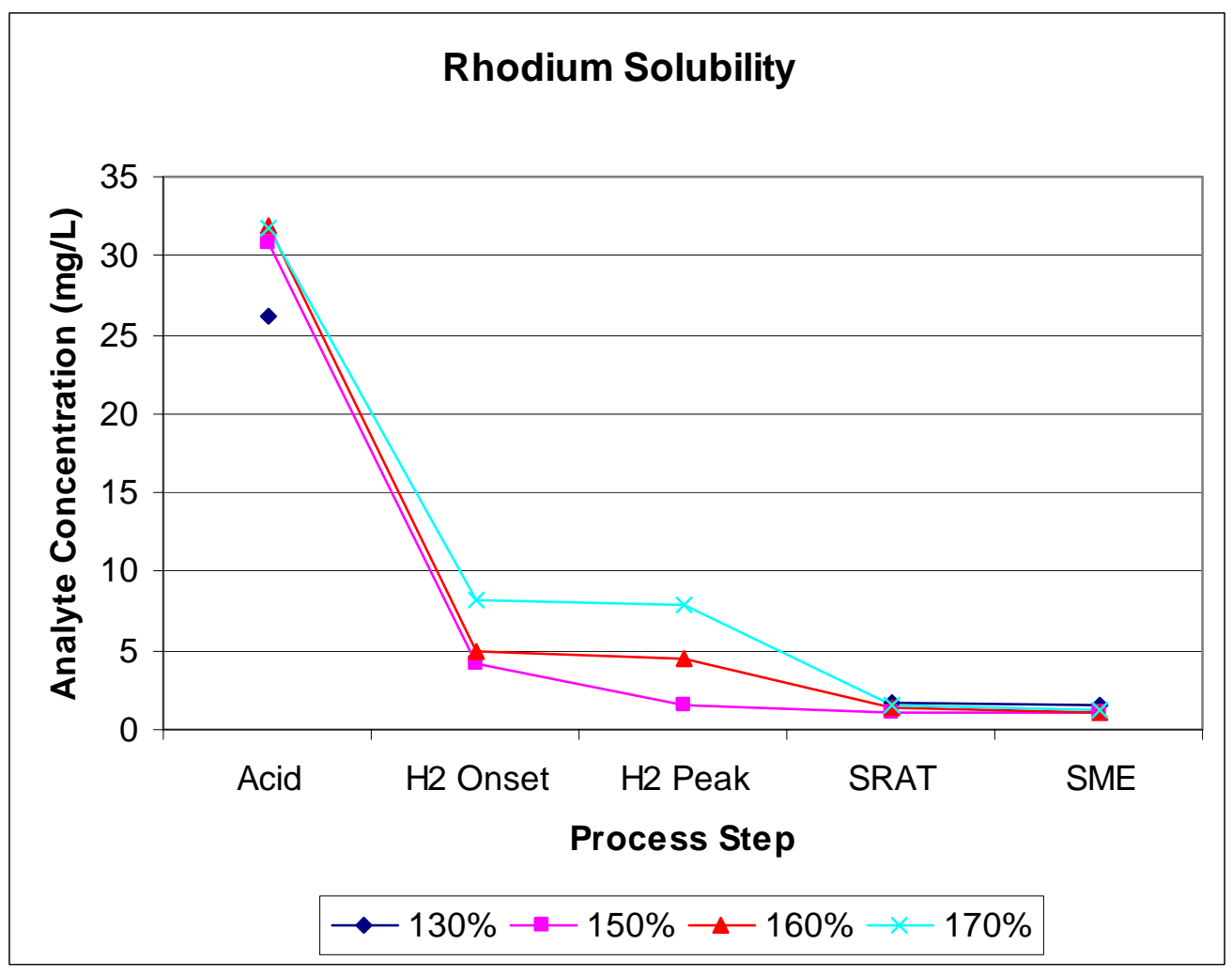

Figure B- 26. Rhodium Solubility 


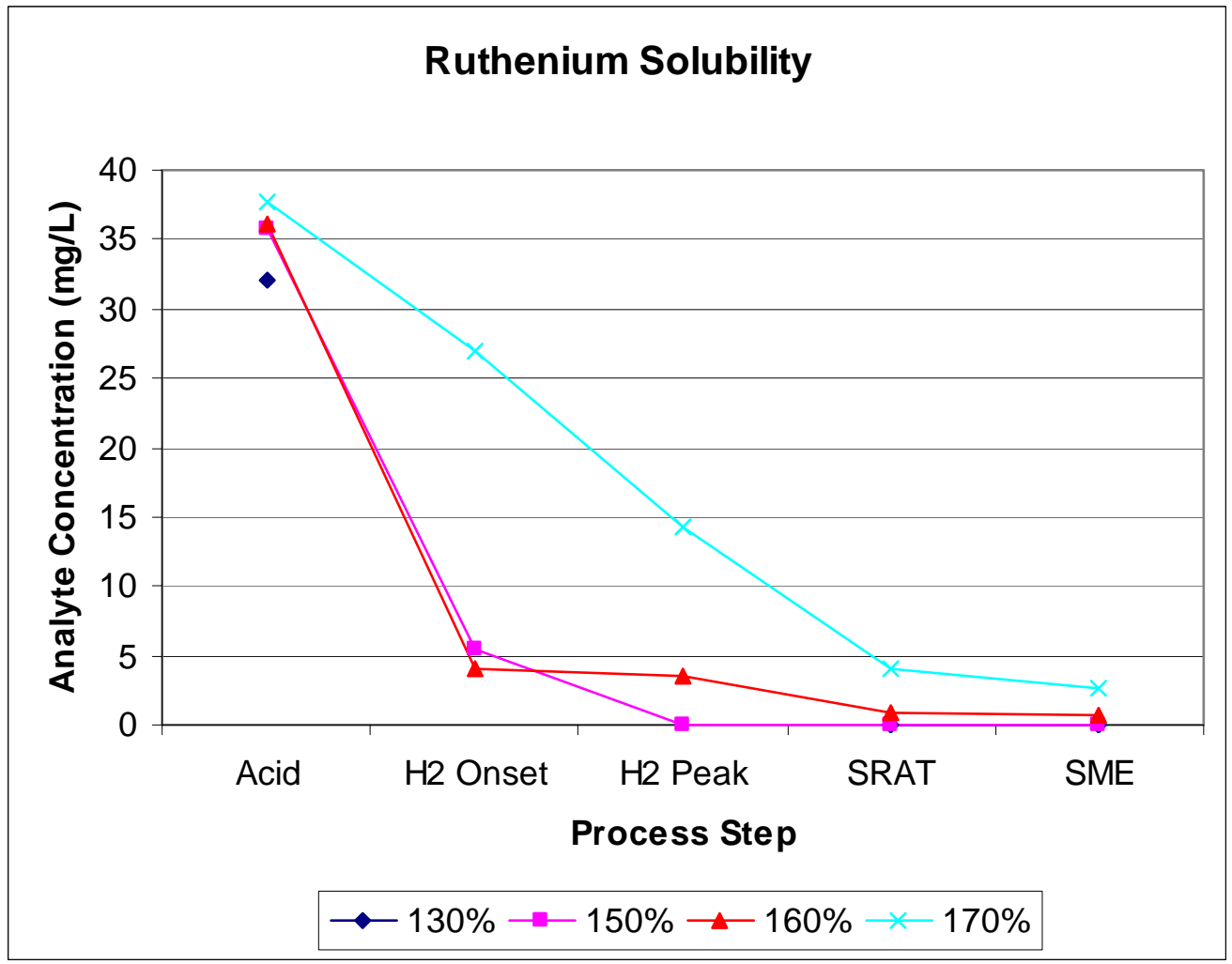

Figure B- 27. Ruthenium Solubility

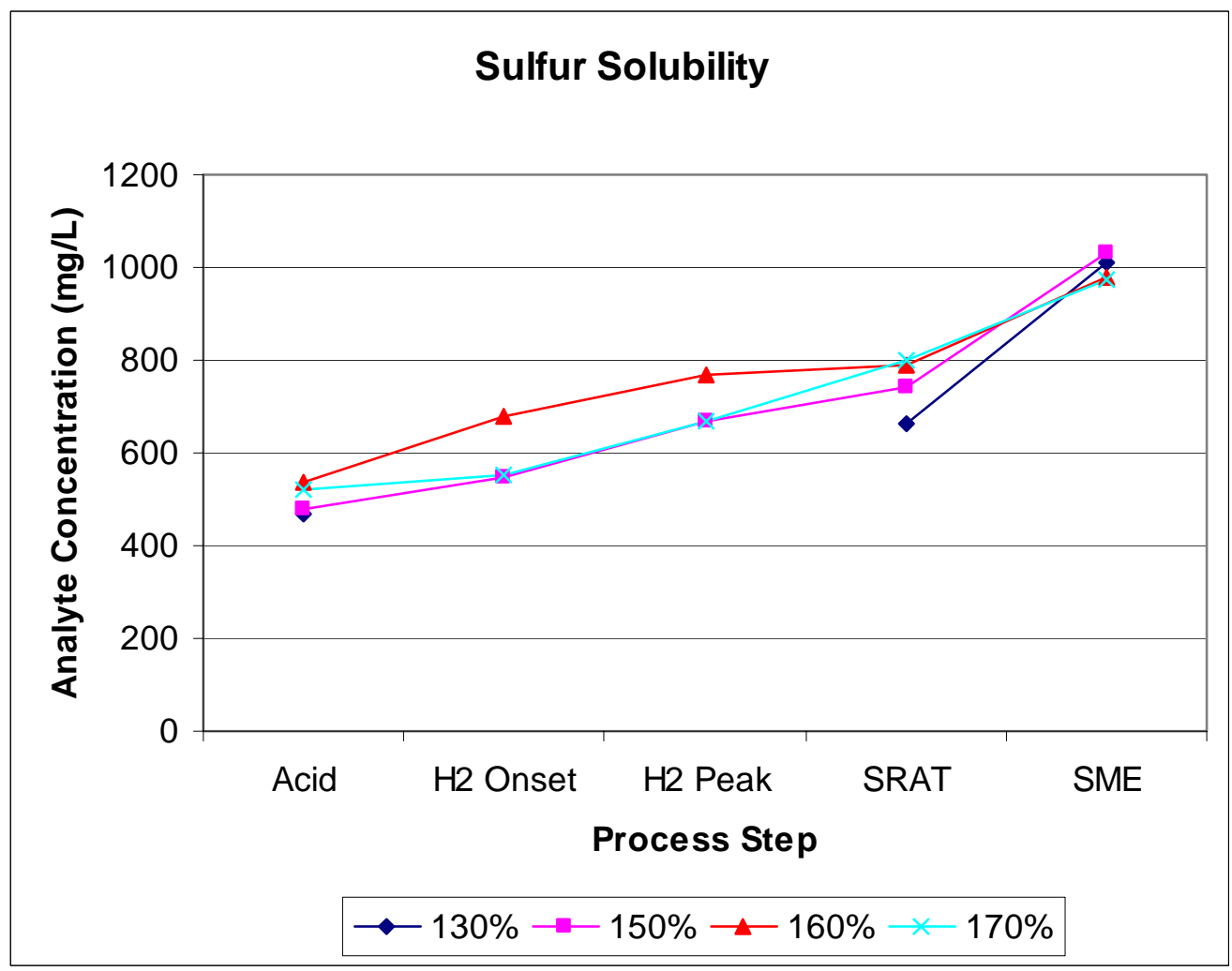

Figure B- 28. Sulfur Solubility 


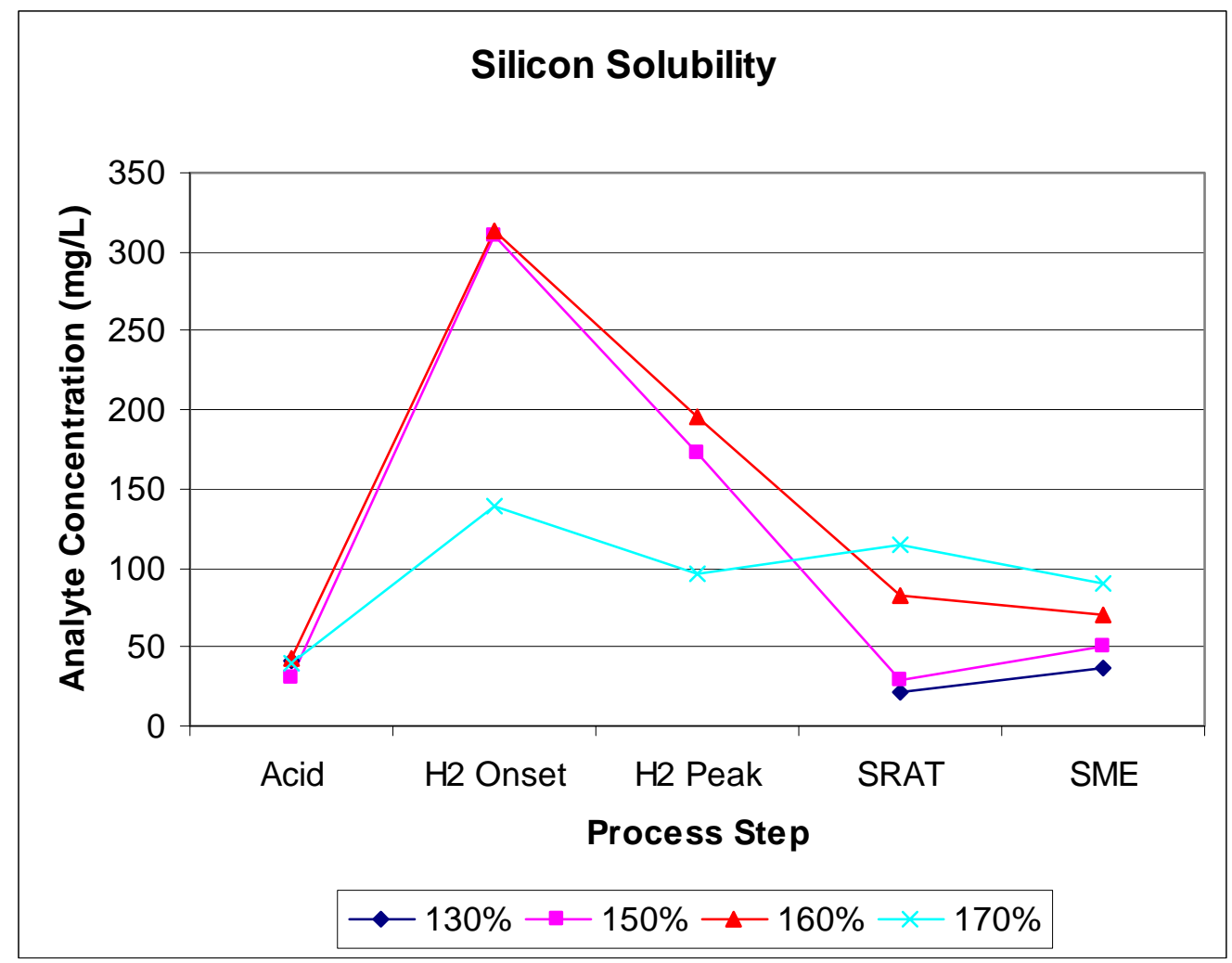

Figure B- 29. Silicon Solubility

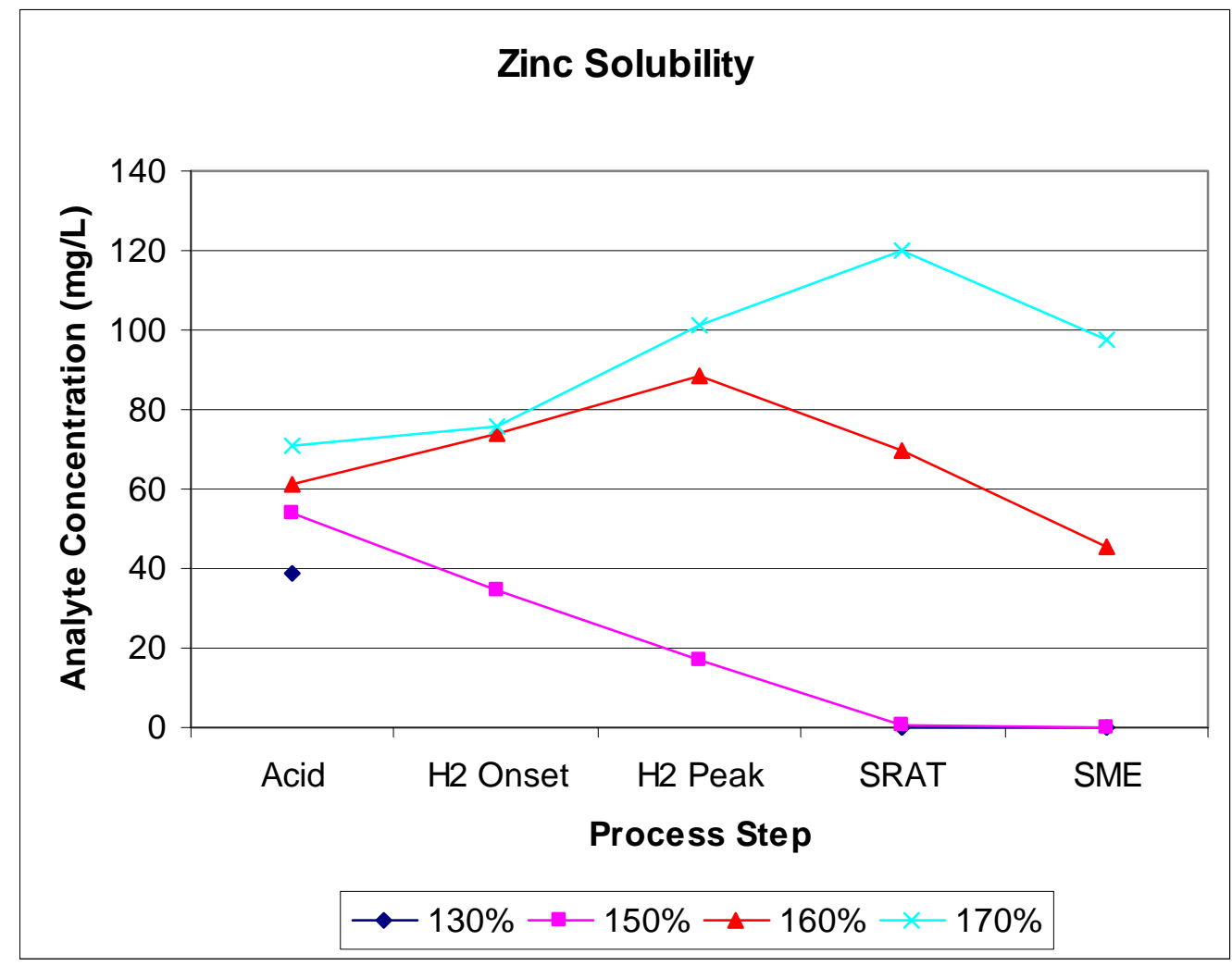

Figure B- 30. Zinc Solubility 


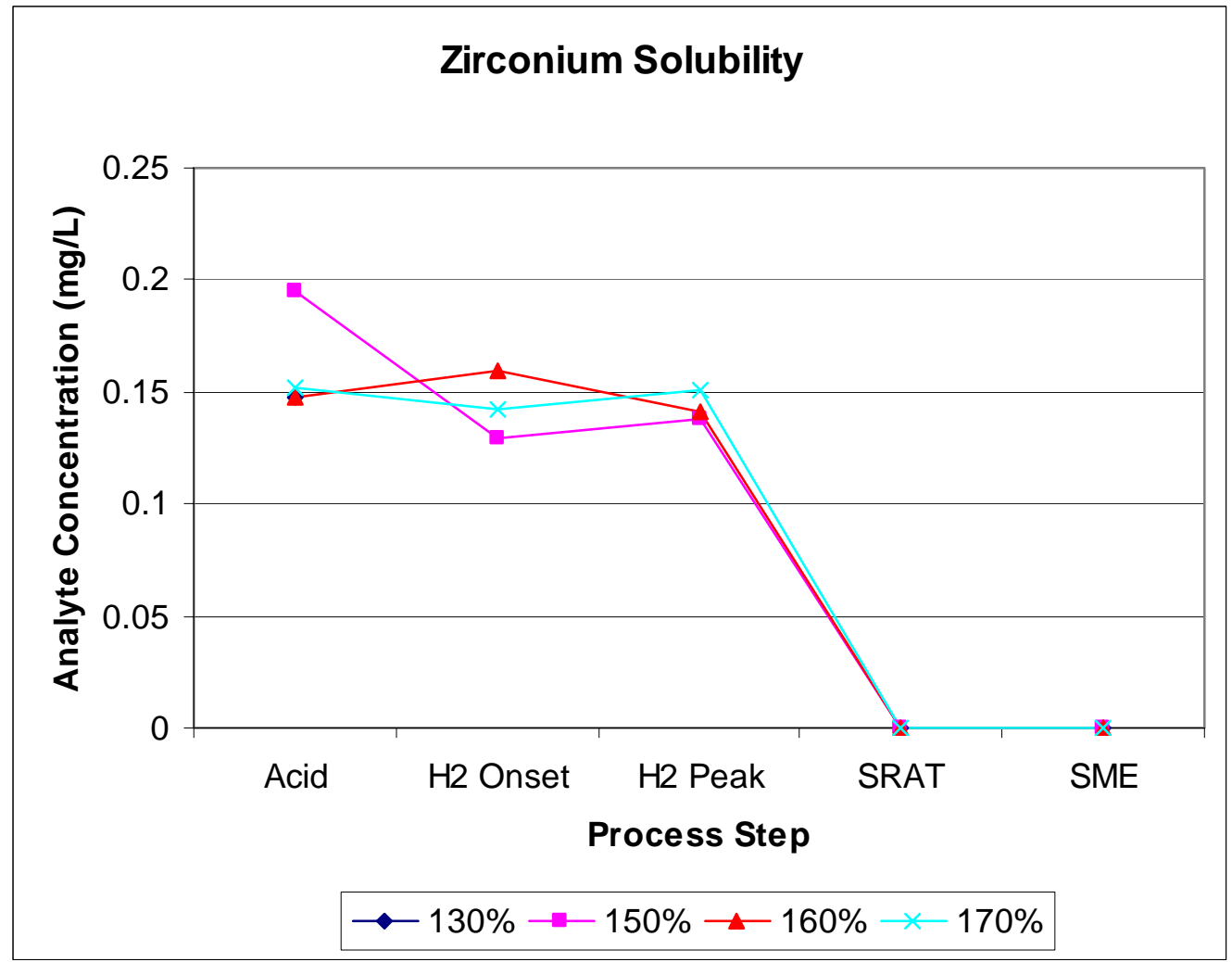

Figure B- 31. Zirconium Solubility

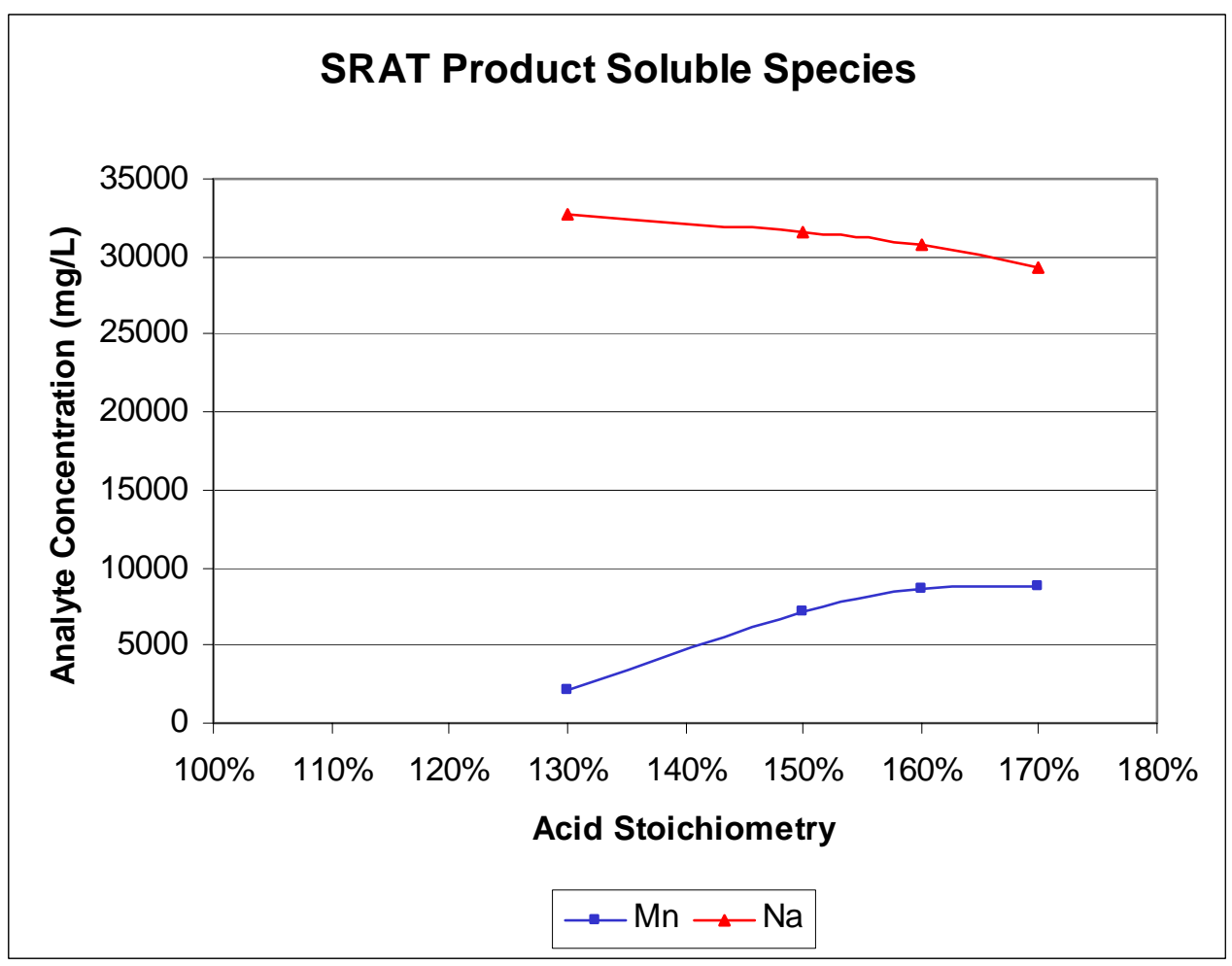

Figure B- 32. SRAT Product Soluble Species: High Concentrations 


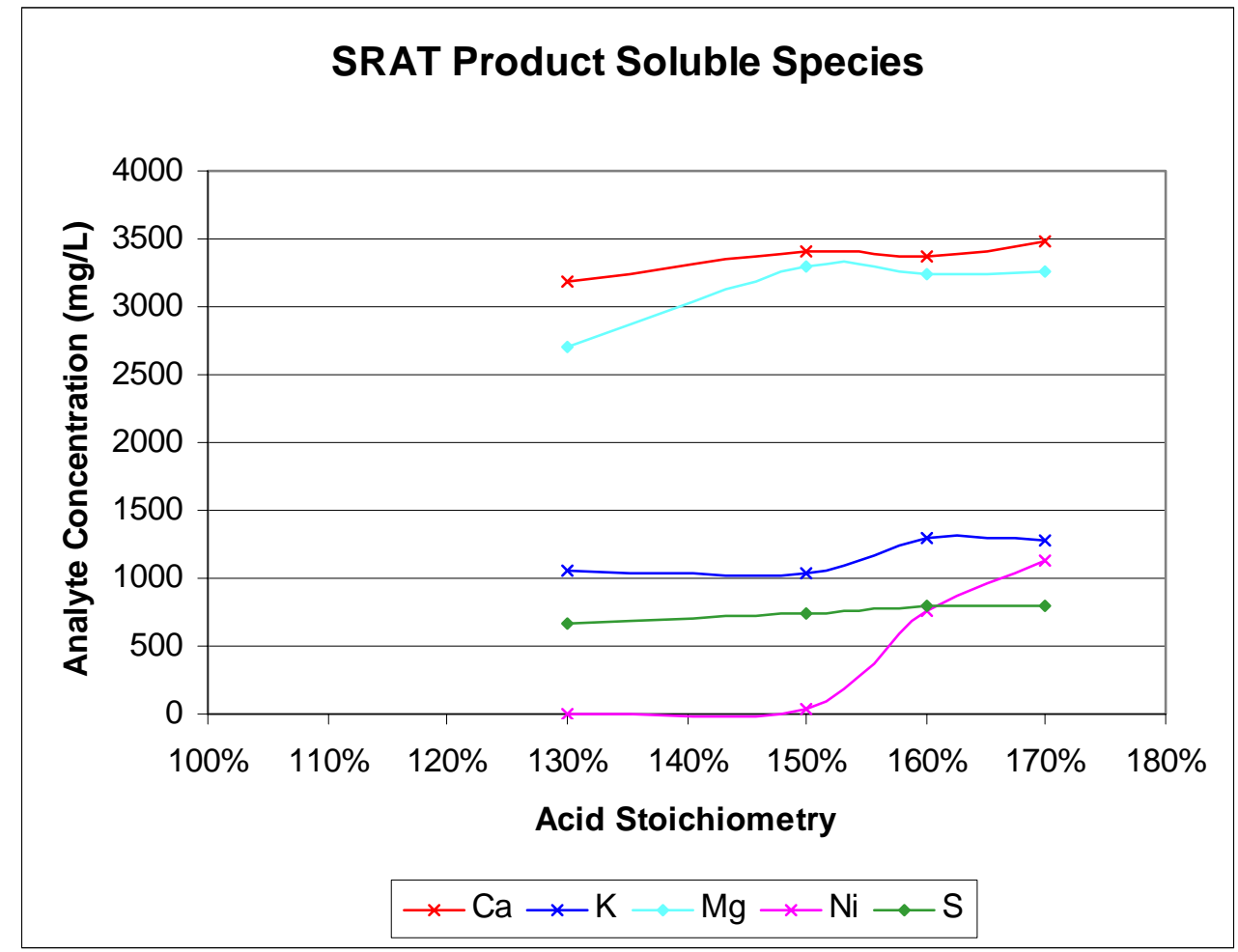

Figure B- 33. SRAT Product Soluble Species: Medium Concentrations

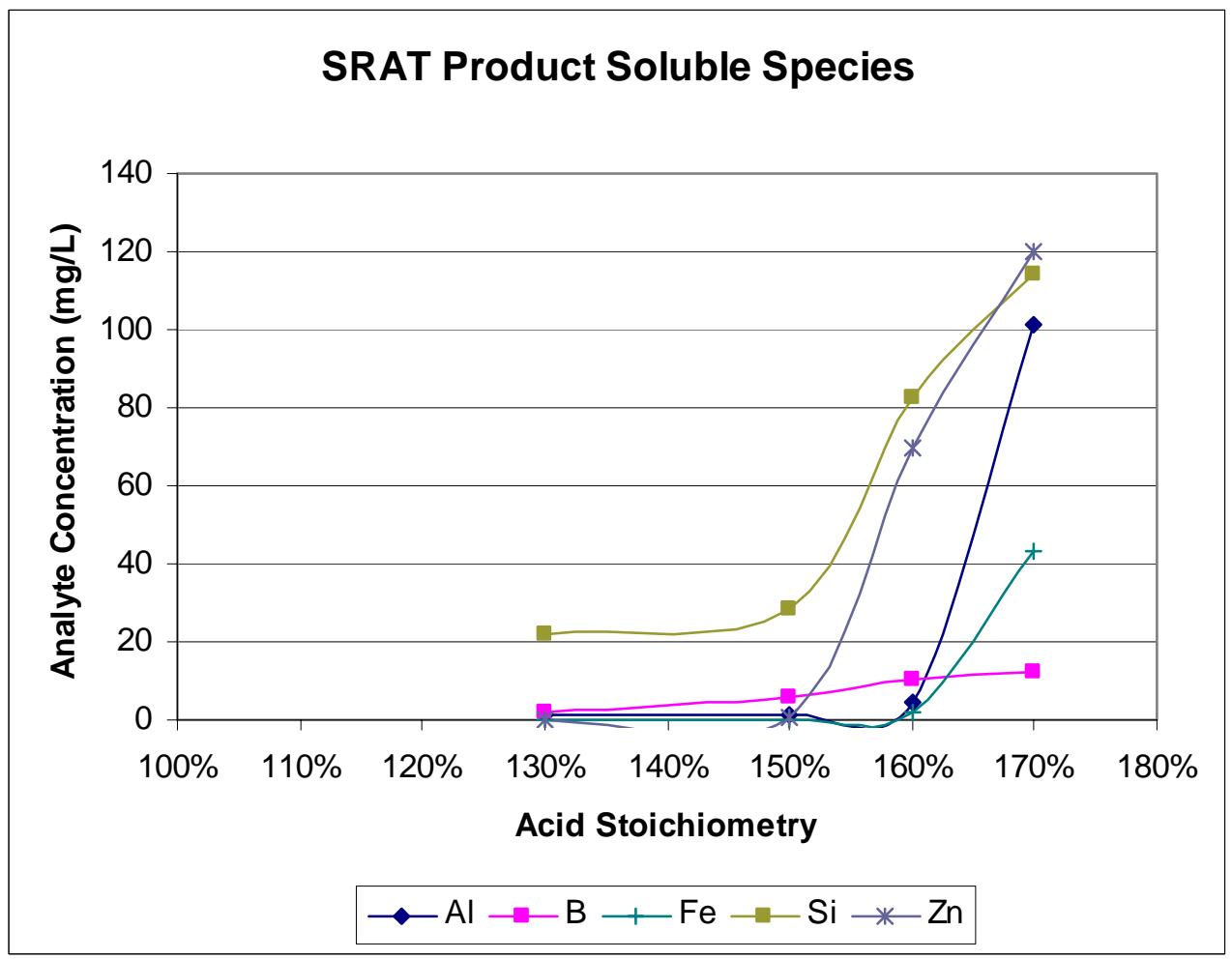

Figure B- 34. SRAT Product Soluble Species: Low Concentrations 


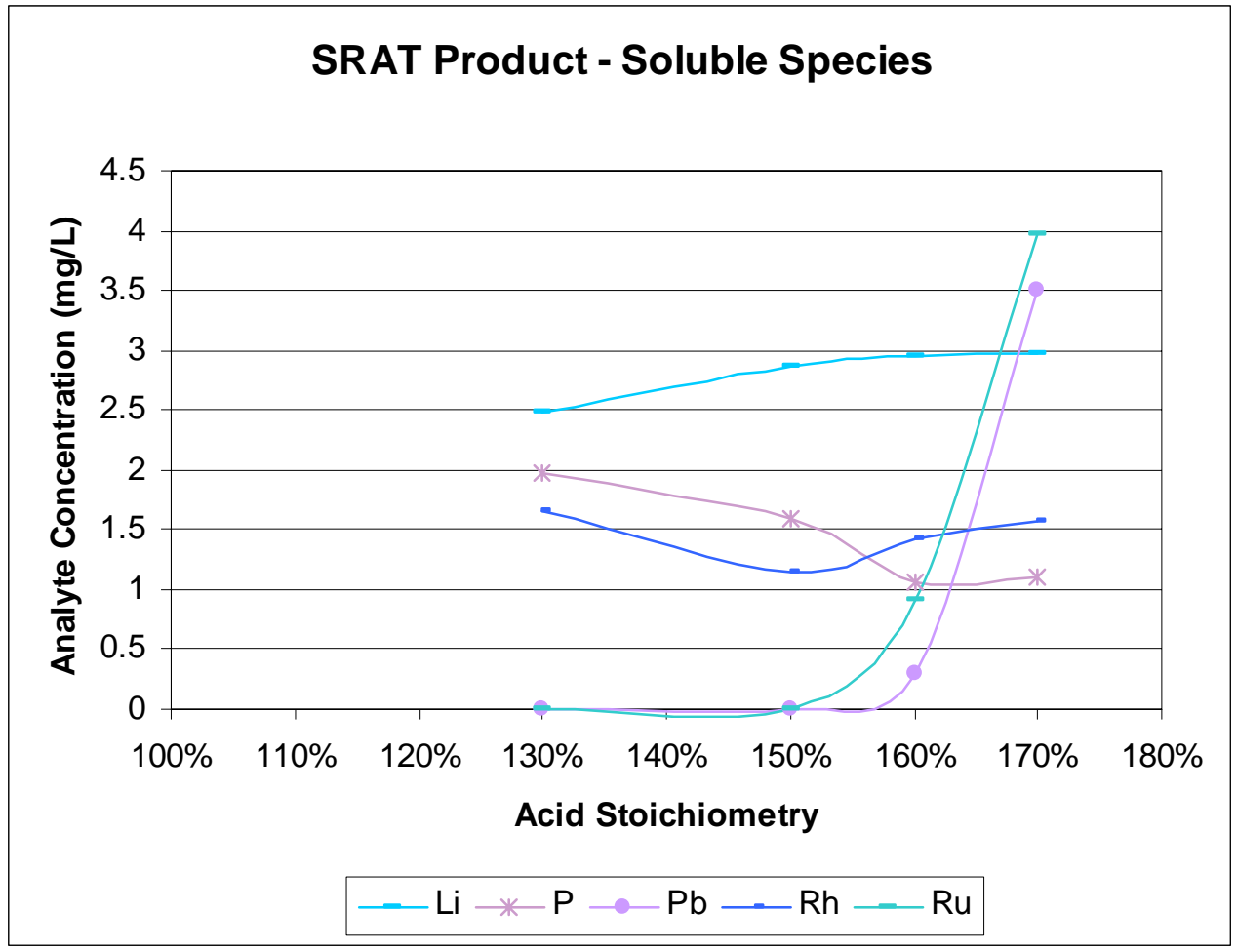

Figure B- 35. SRAT Product Soluble Species: Very Low Concentrations

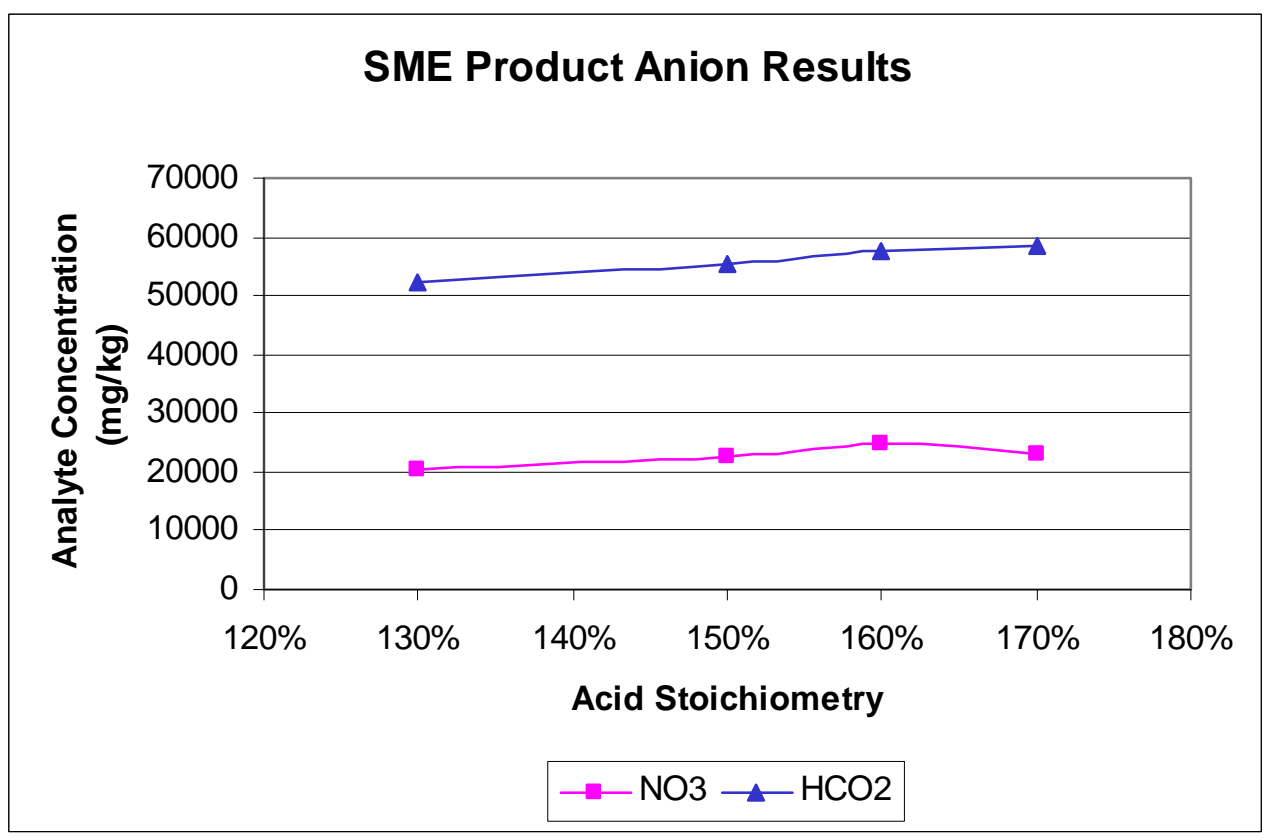

Figure B- 36. SME Product Nitrate and Formate versus Acid Stoichiometry 
WSRC-STI-2006-00109

Revision 0

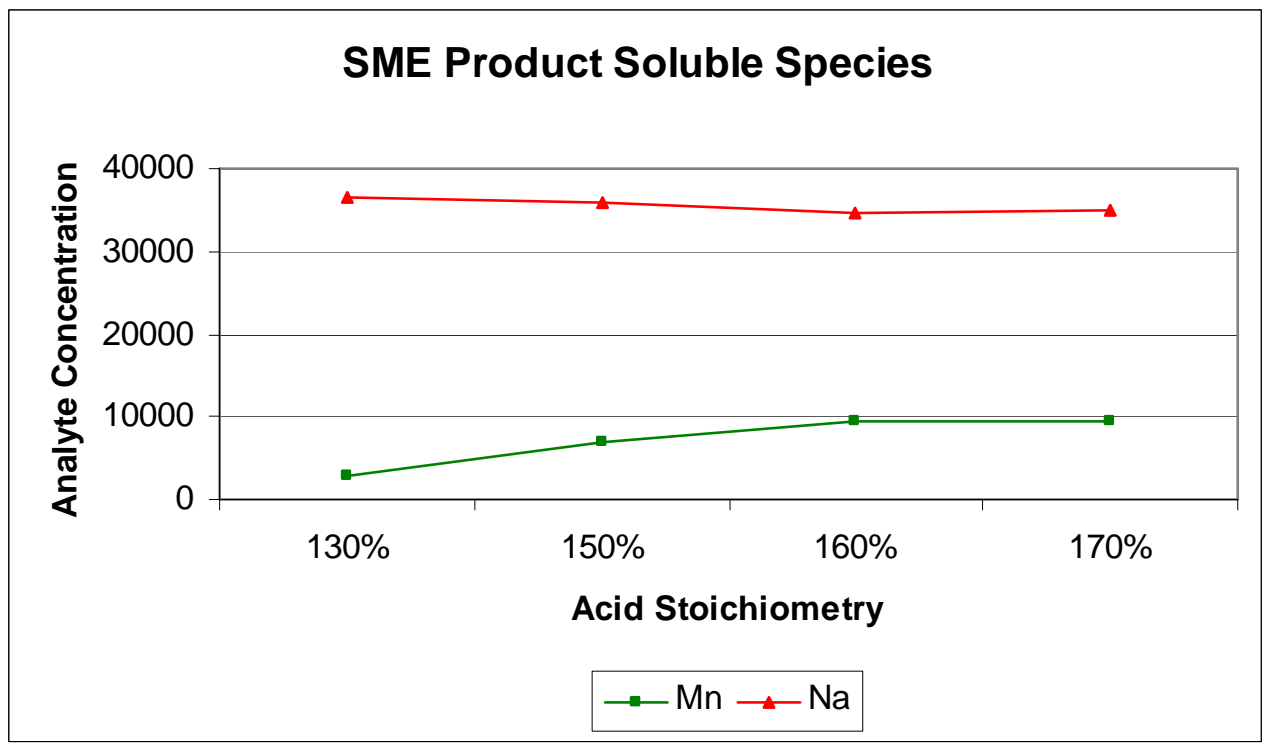

Figure B- 37. SME Product Soluble Species: Very High Concentrations

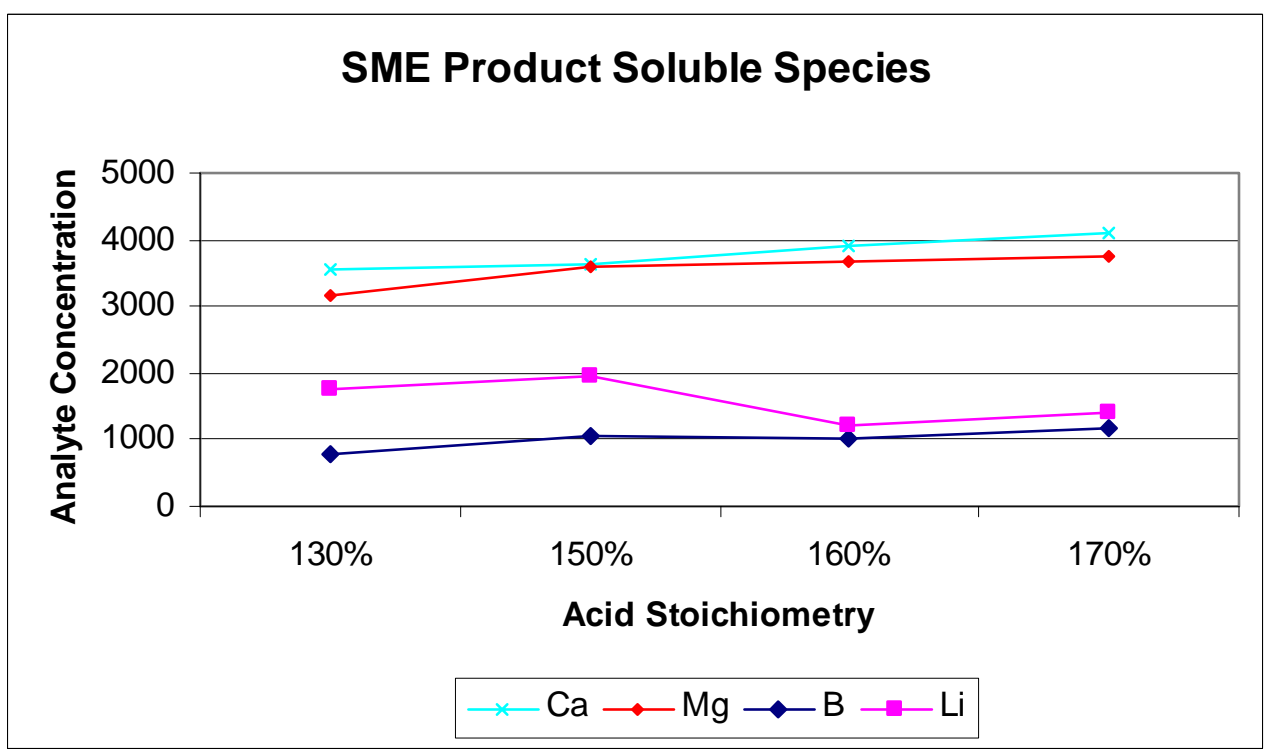

Figure B- 38. SME Product Soluble Species: High Concentrations 
WSRC-STI-2006-00109

Revision 0

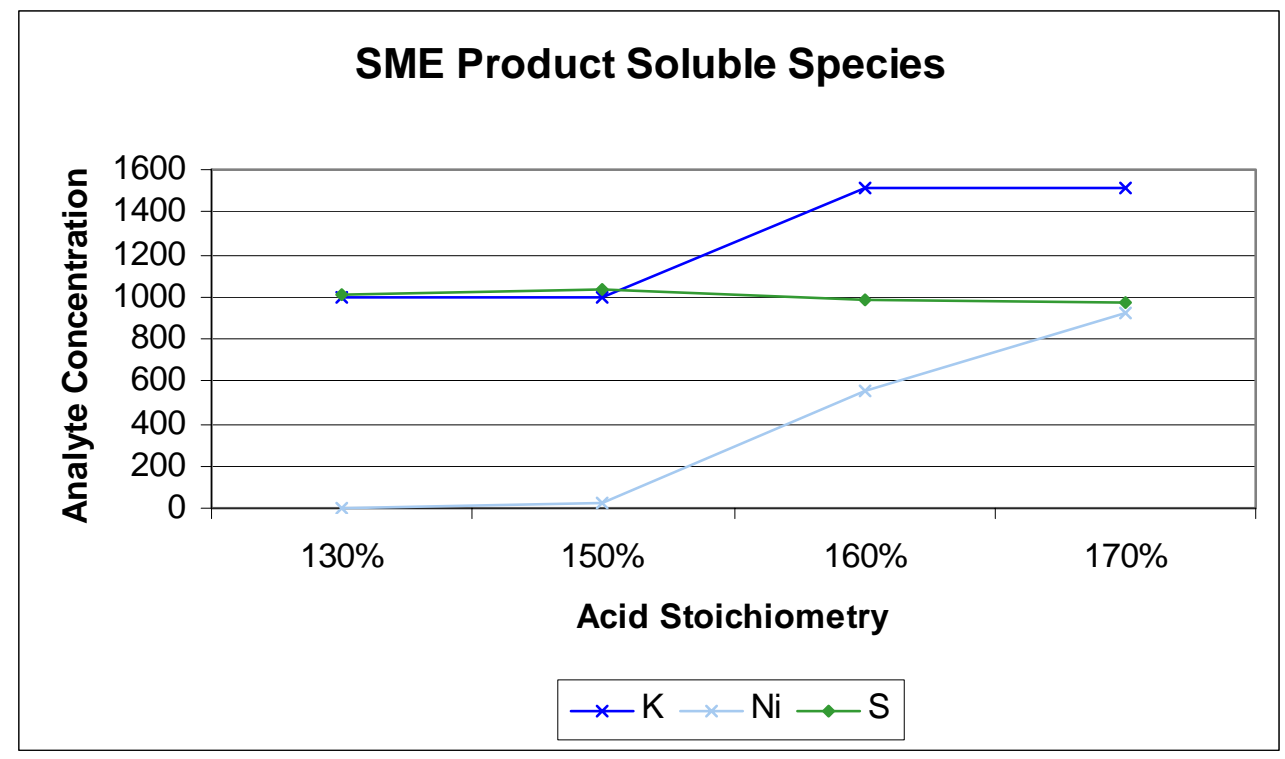

Figure B- 39. SME Product Soluble Species: Medium Concentrations

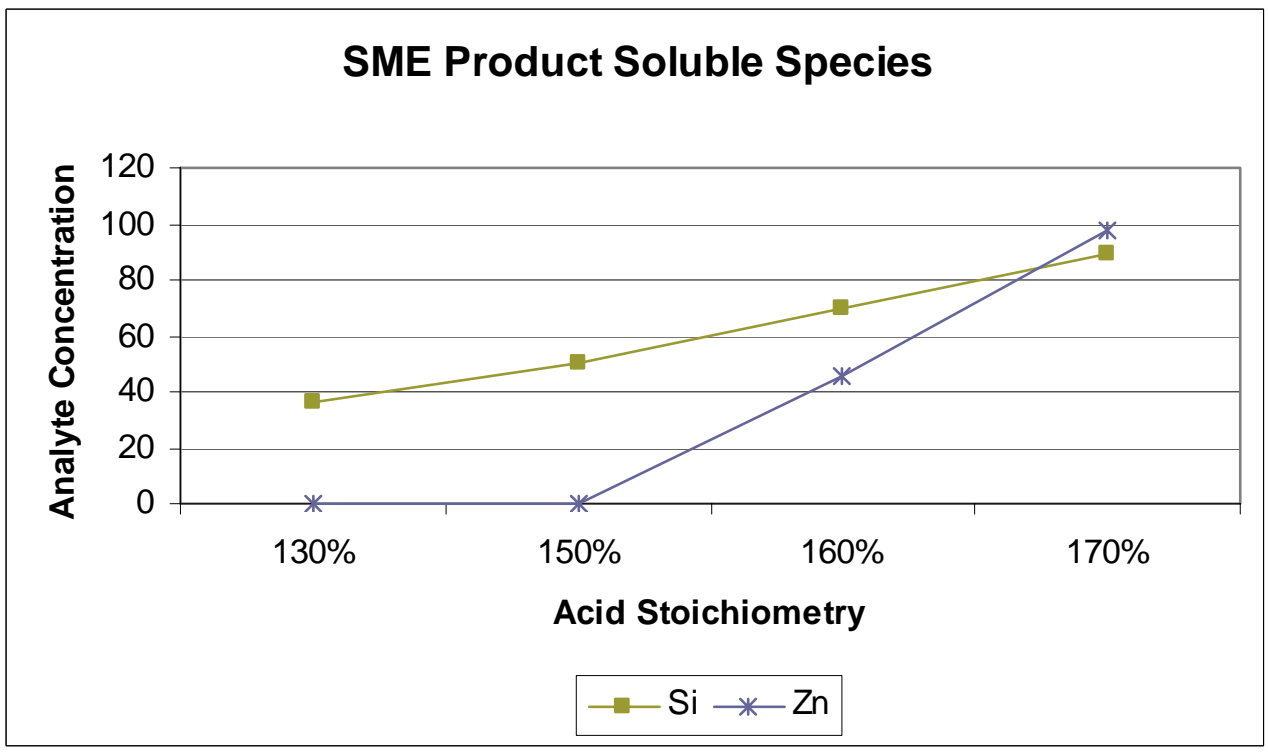

Figure B- 40. SME Product Soluble Species: Low Concentrations 


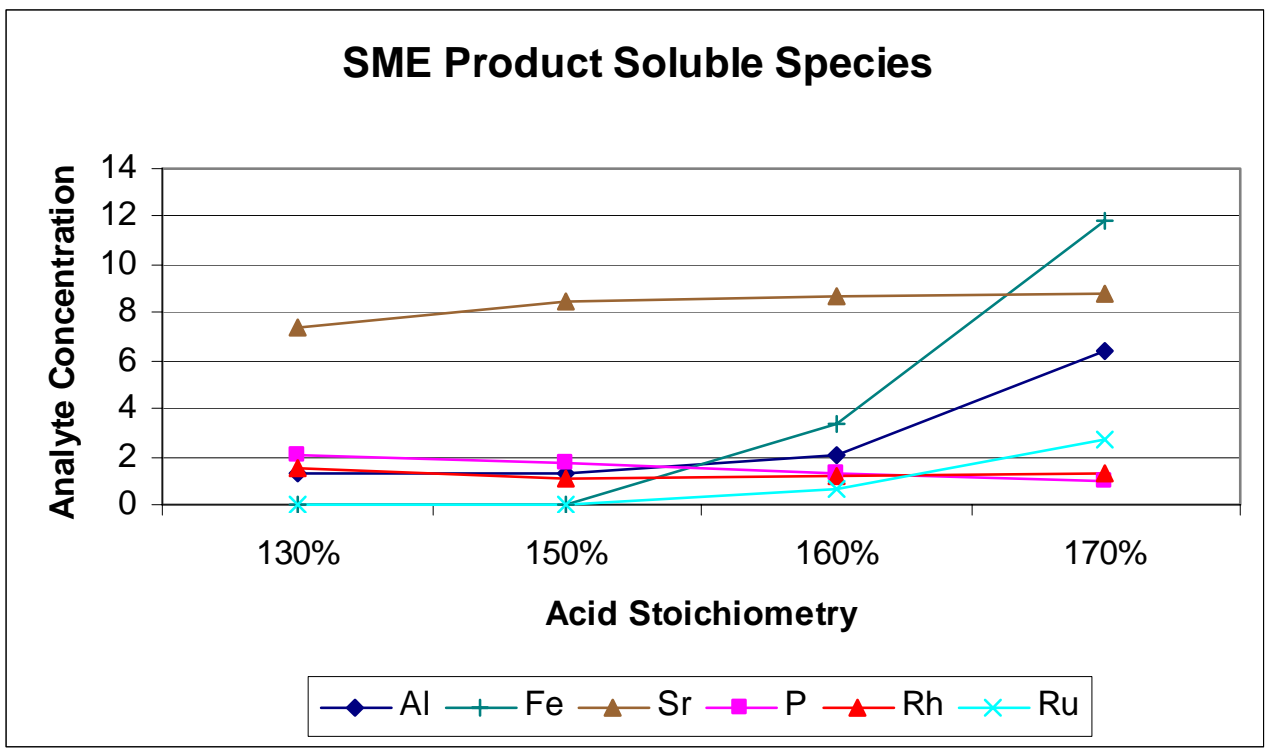

Figure B- 41. SME Product Soluble Species: Very Low Concentrations

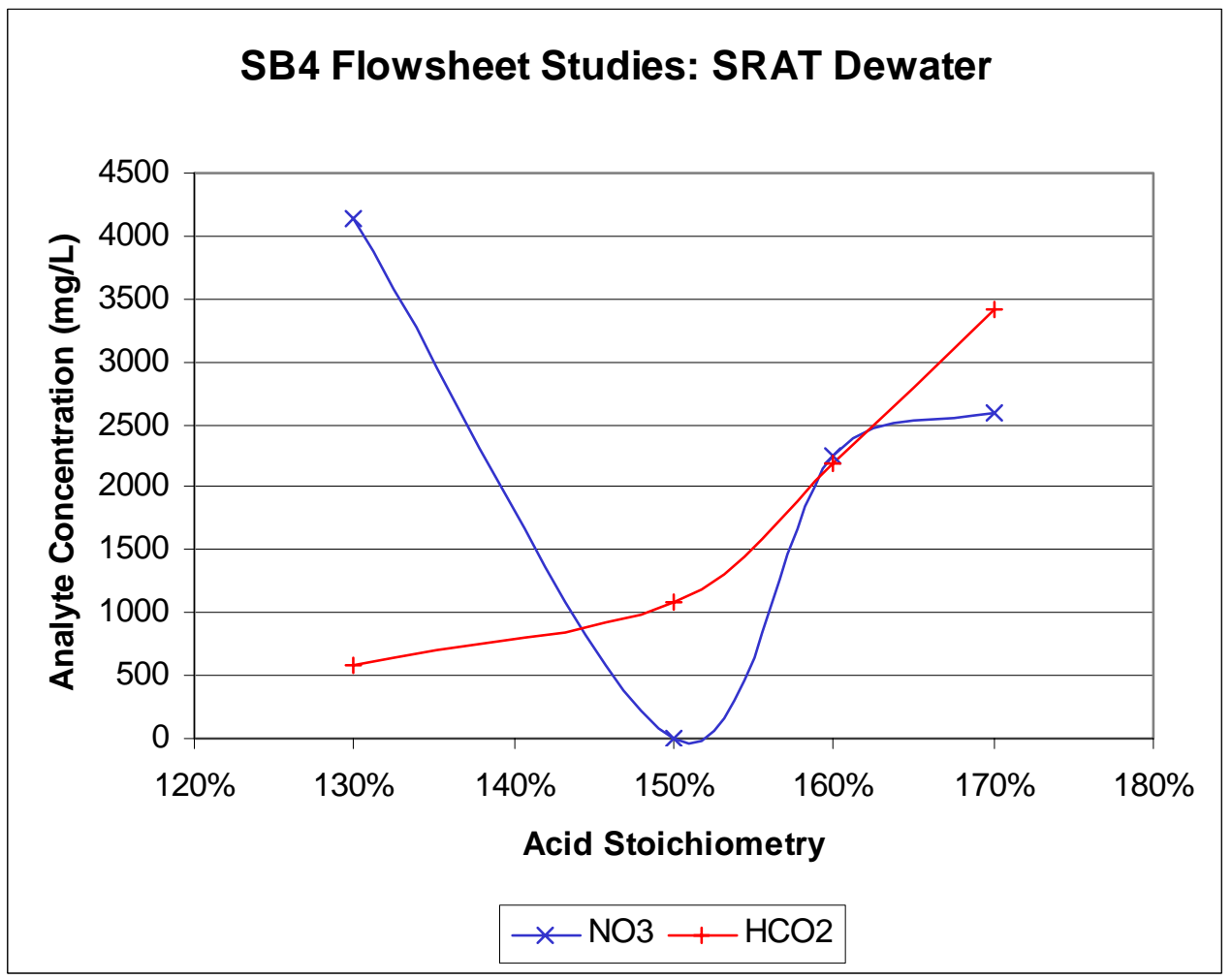

Figure B- 42. SRAT Dewater Anion Concentrations 


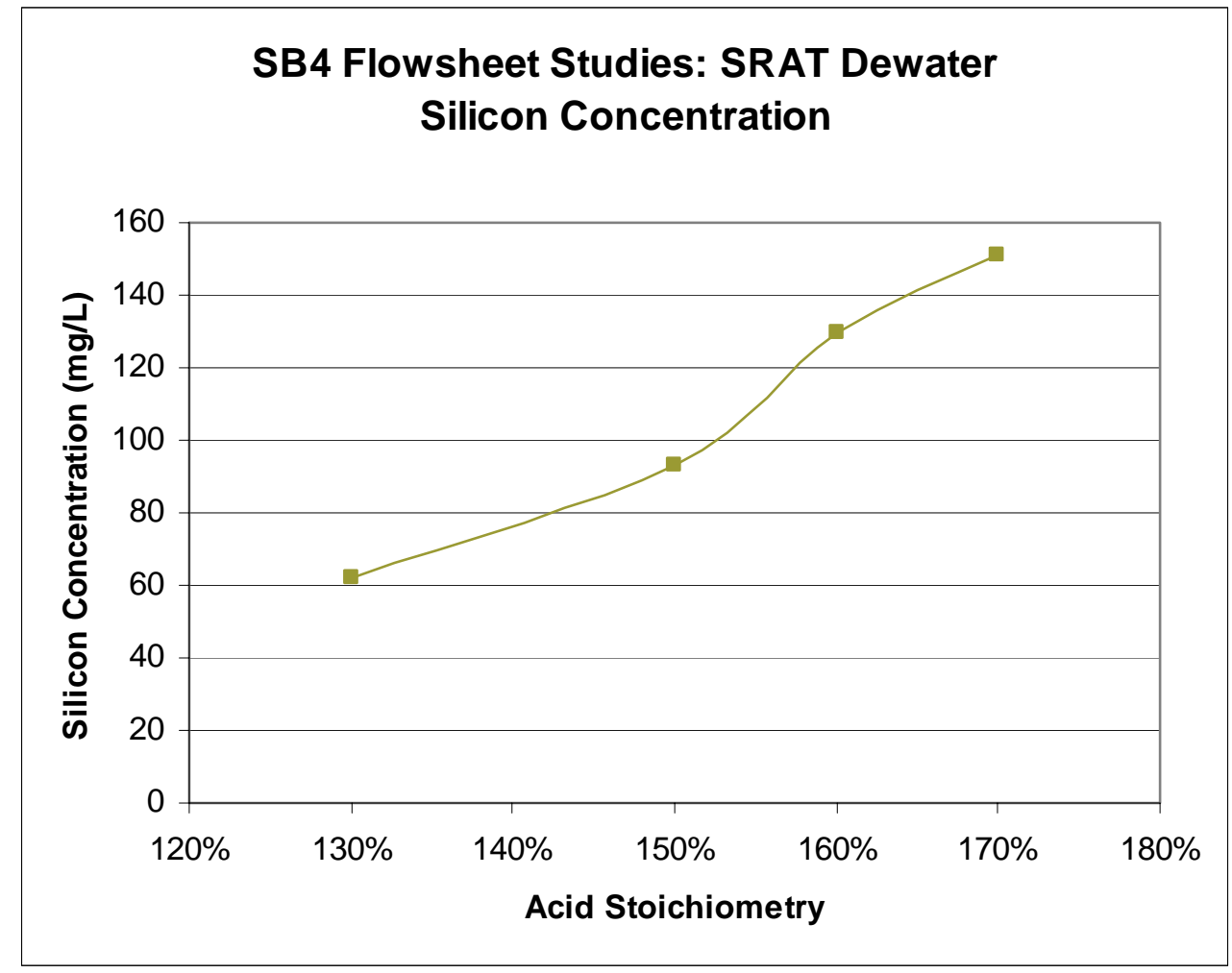

Figure B- 43. SRAT Dewater Silicon Concentration

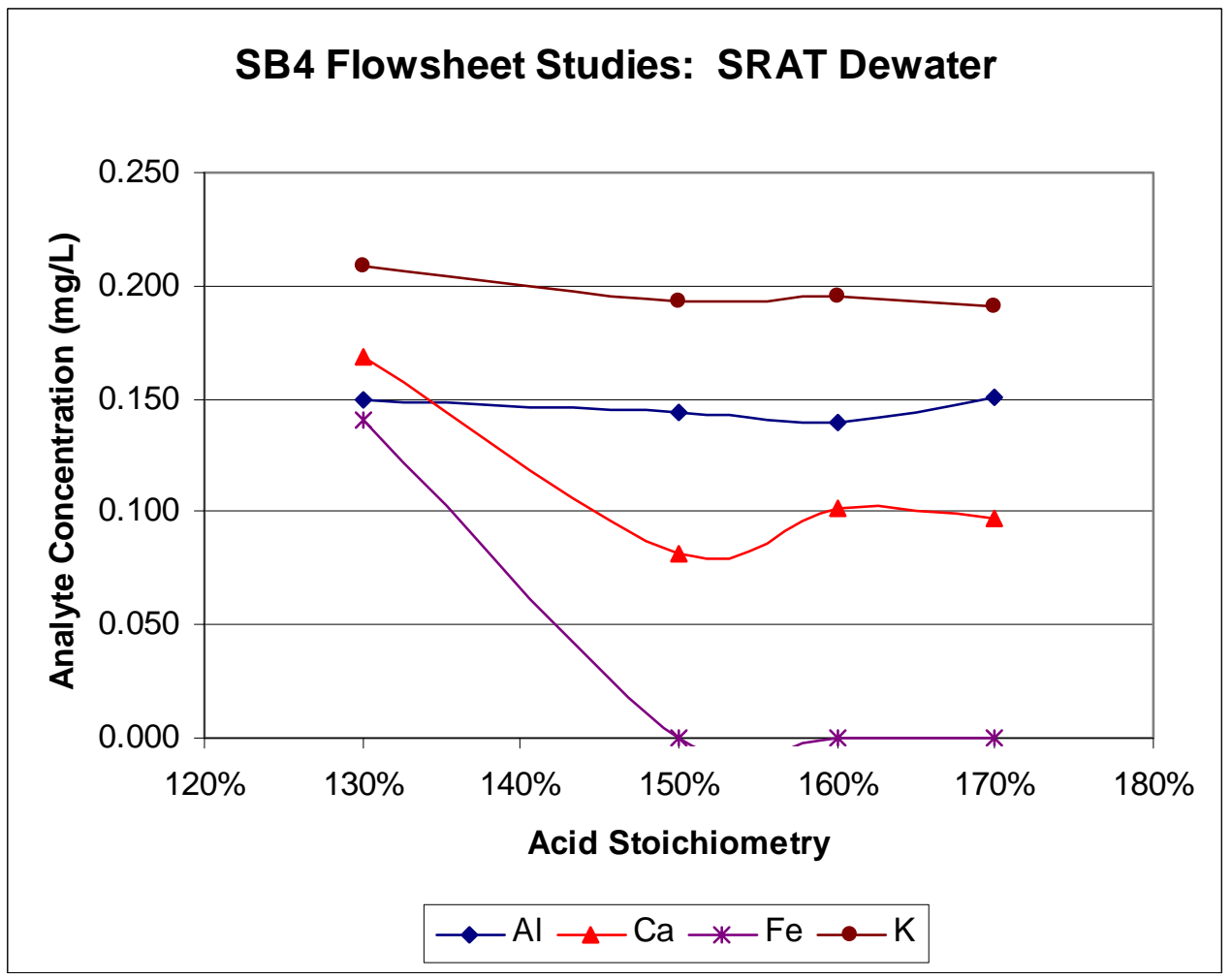

Figure B- 44. SRAT Dewater Elementals 


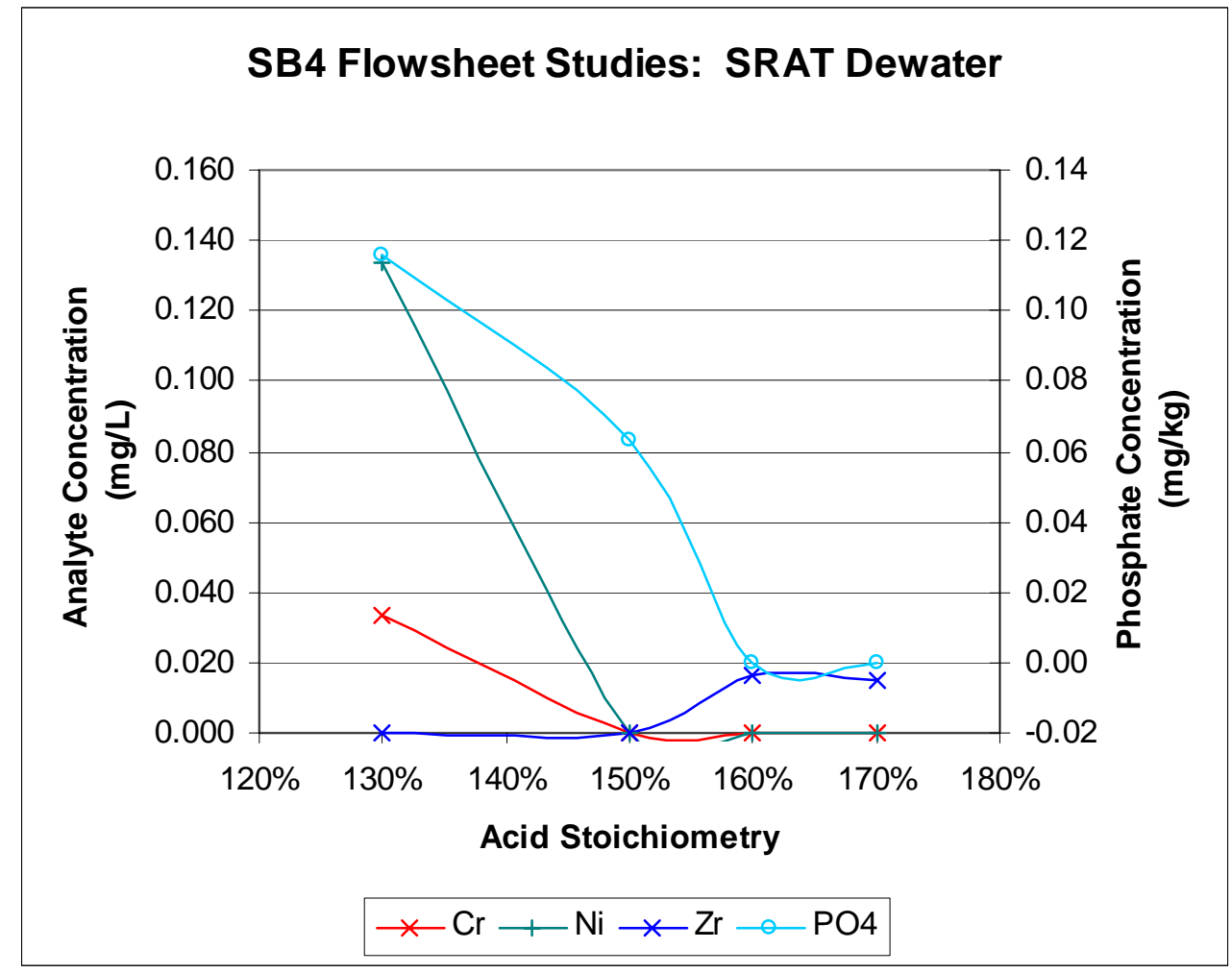

Figure B- 45. SRAT Dewater Trace Elementals

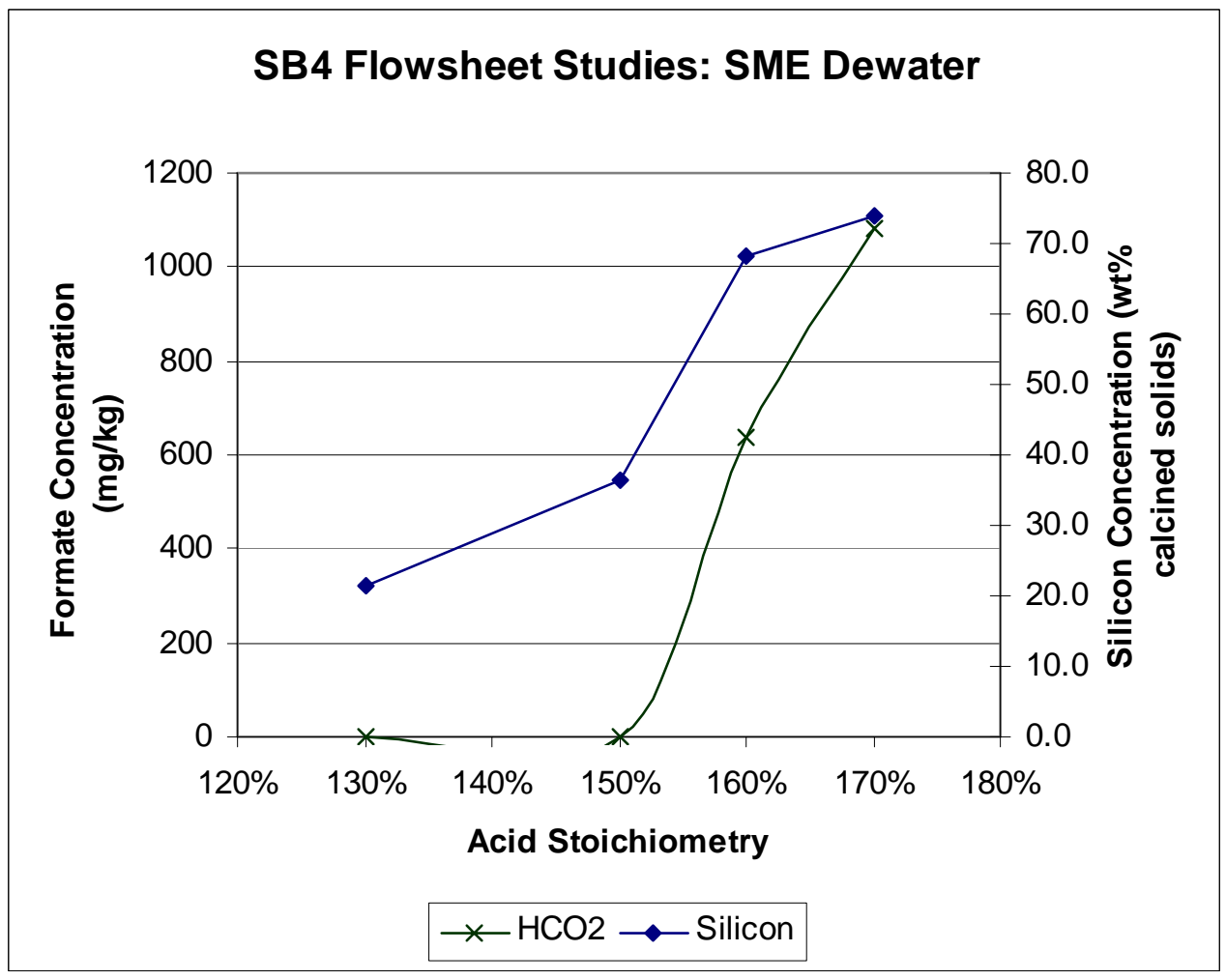

Figure B- 46. SME Dewater Formate and Silicon Concentrations 


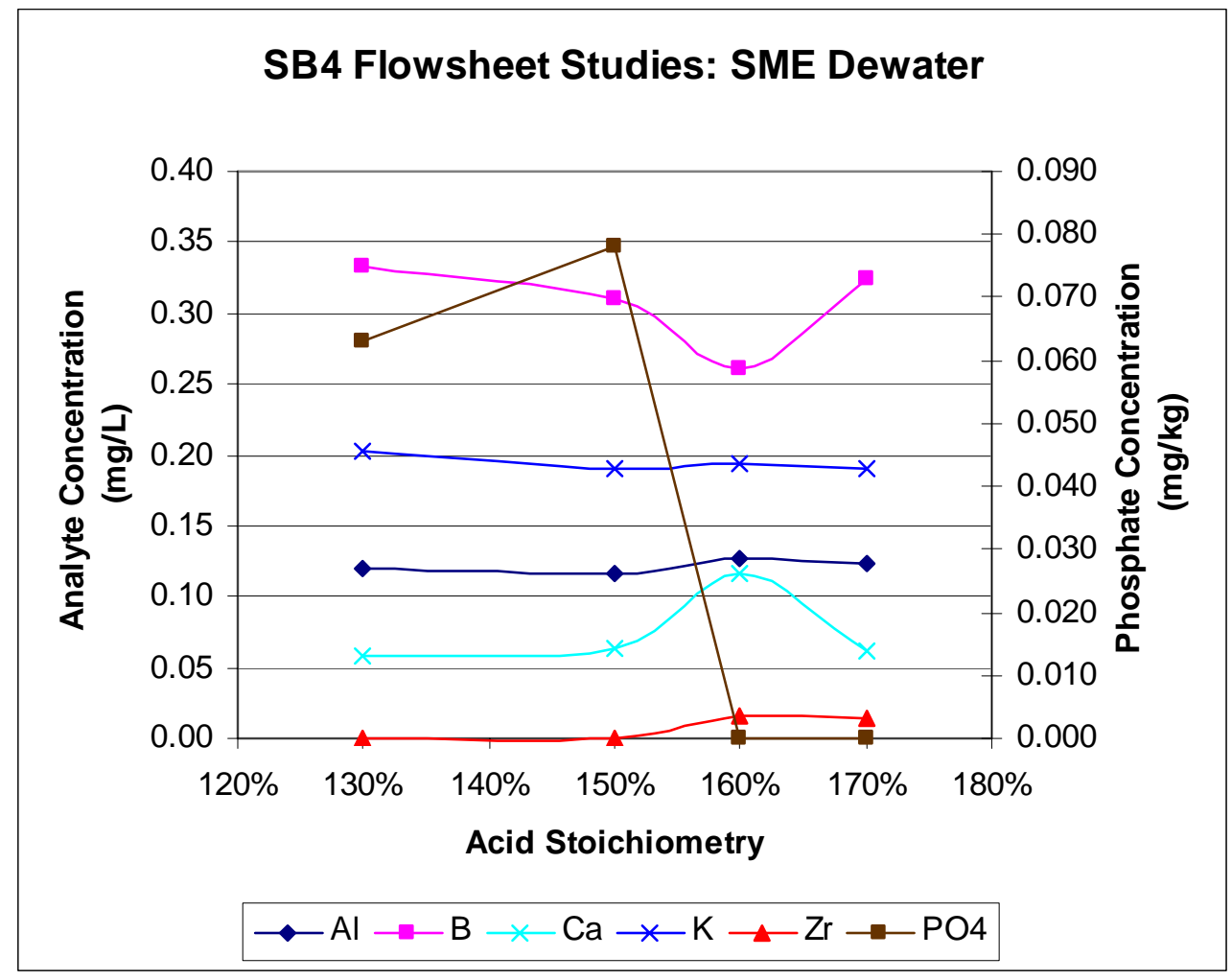

Figure B- 47. SME Dewater Elementals

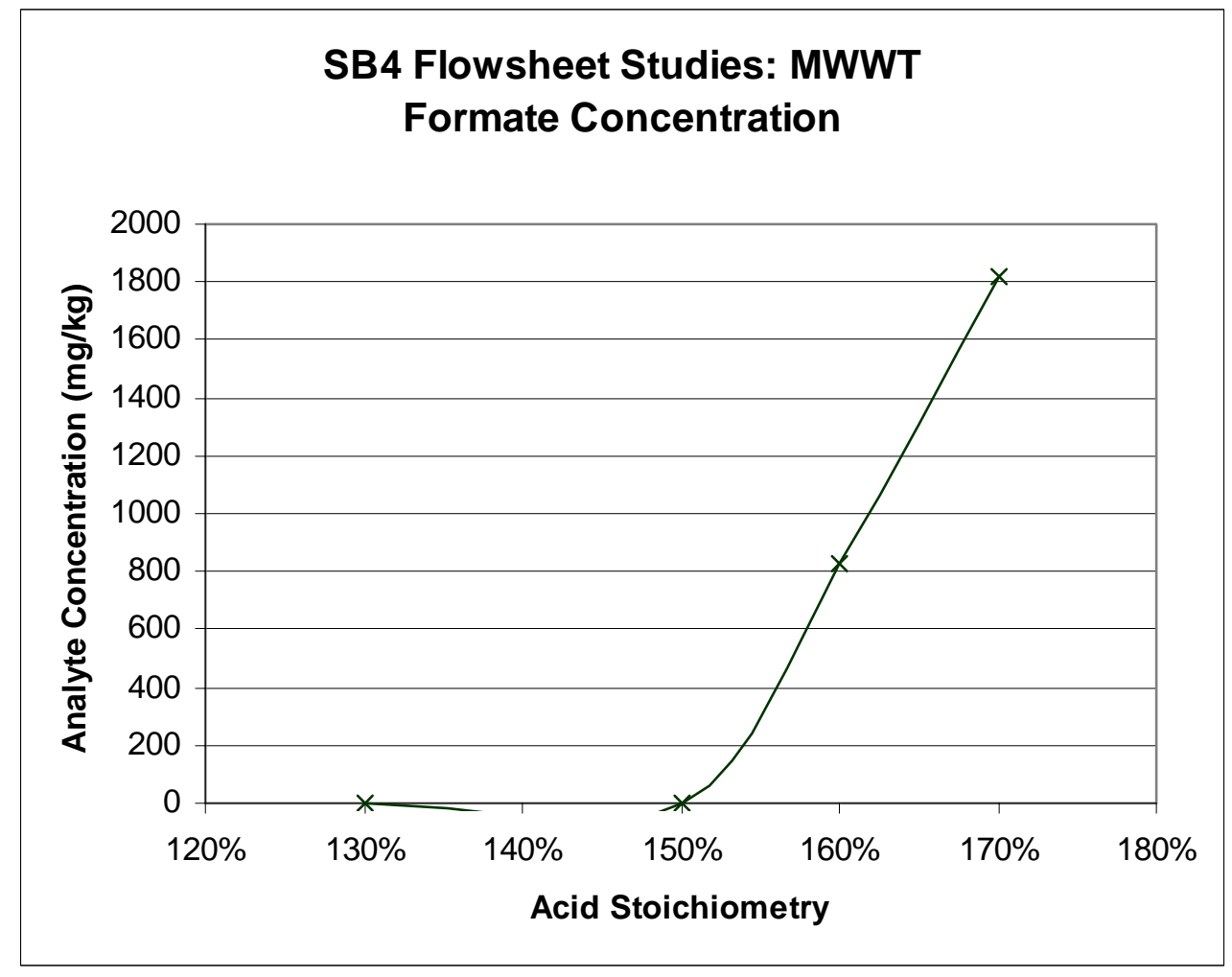

Figure B- 48. MWWT Formate Concentration 
WSRC-STI-2006-00109

Revision 0

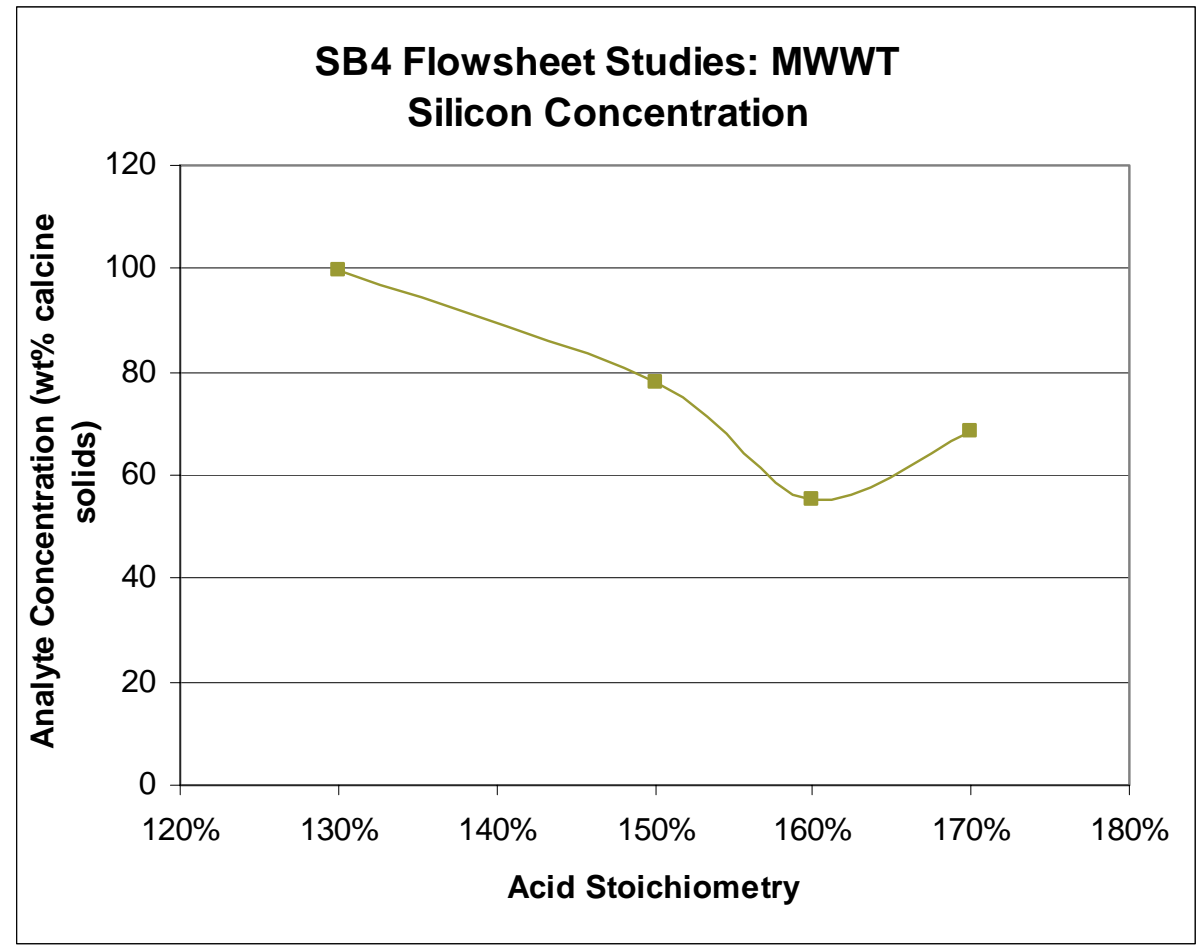

Figure B- 49. MWWT Silicon Concentration

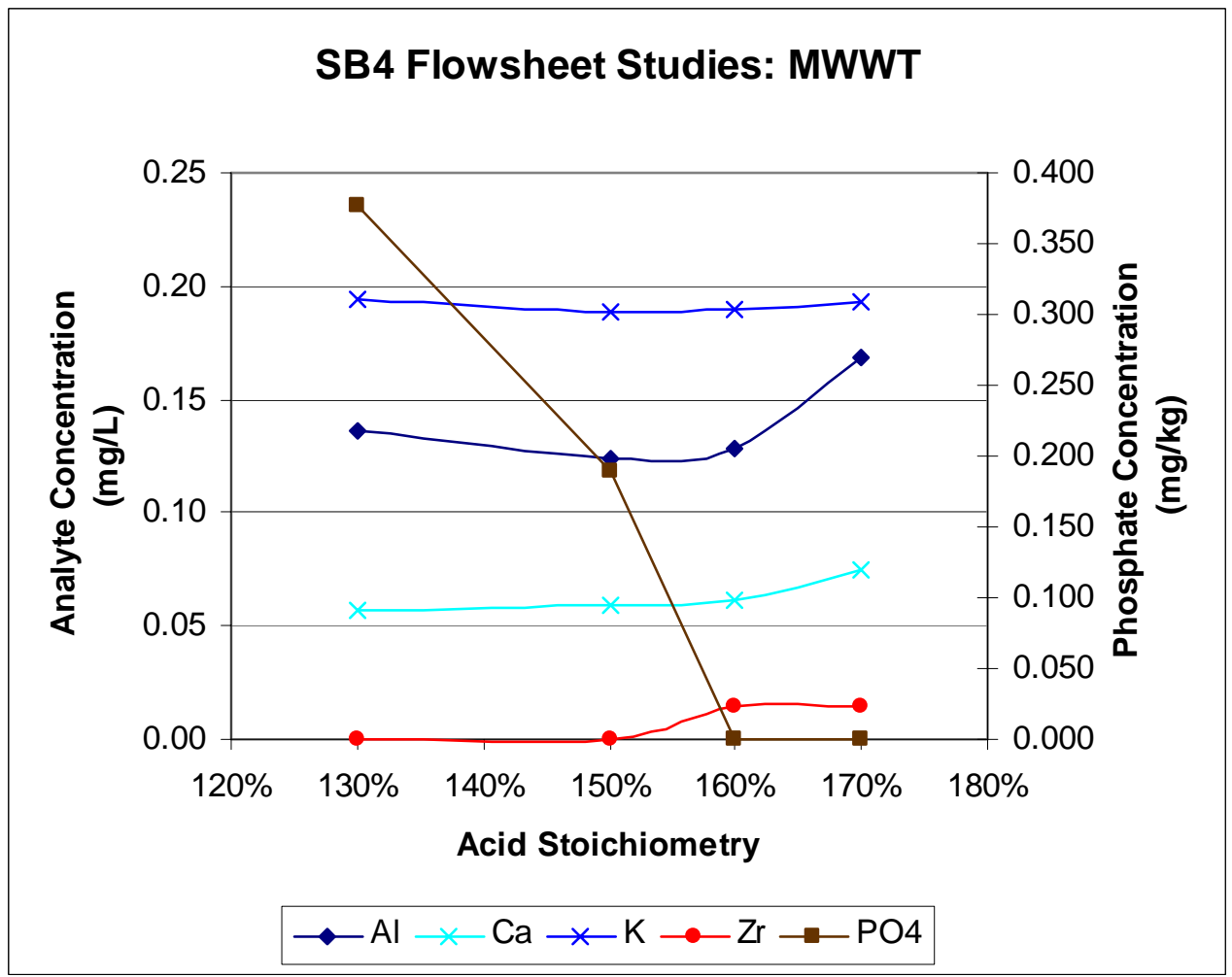

Figure B- 50. MWWT Elementals 


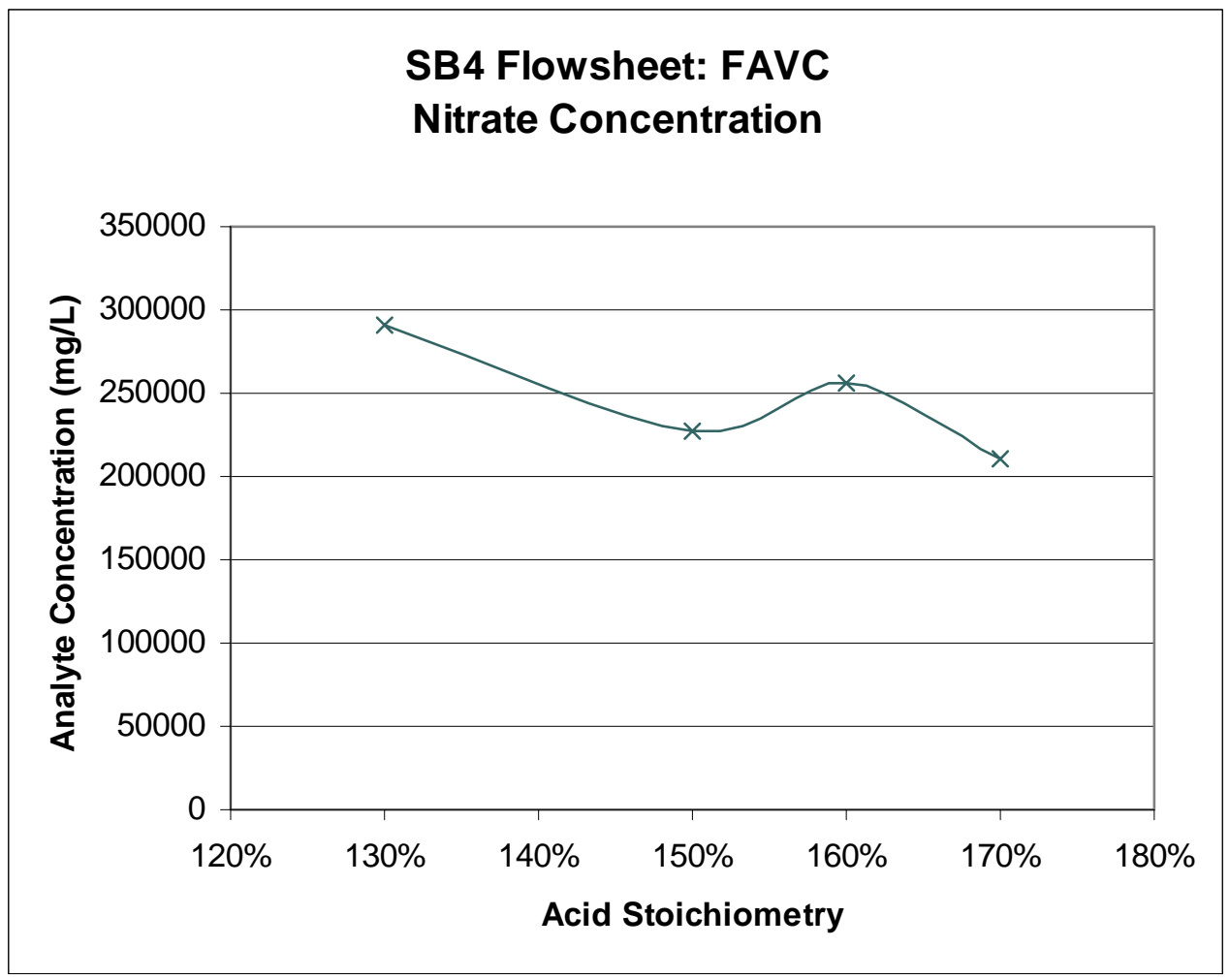

Figure B- 51. FAVC Nitrate Concentration

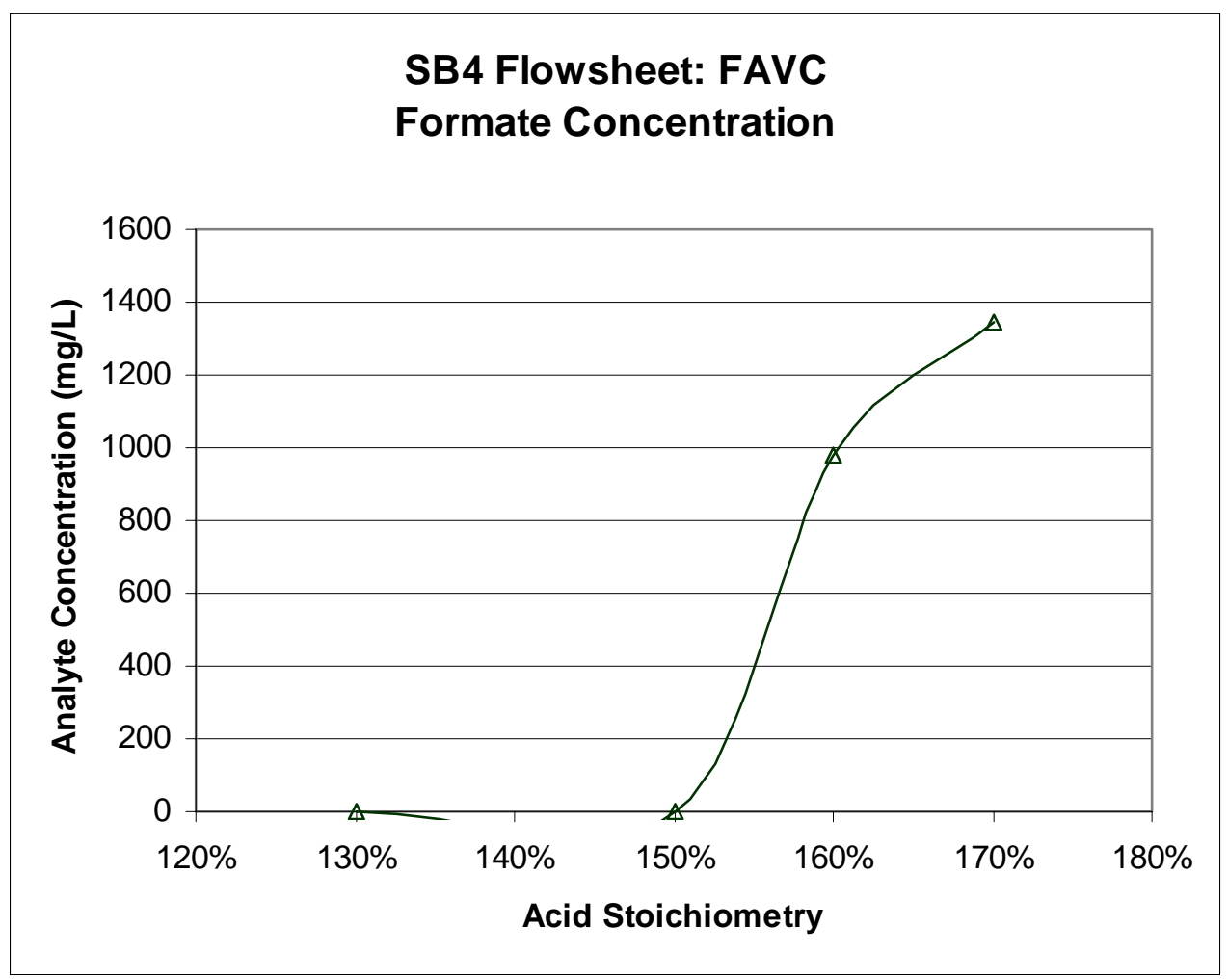

Figure B- 52. FAVC Formate Concentration 
WSRC-STI-2006-00109

Revision 0

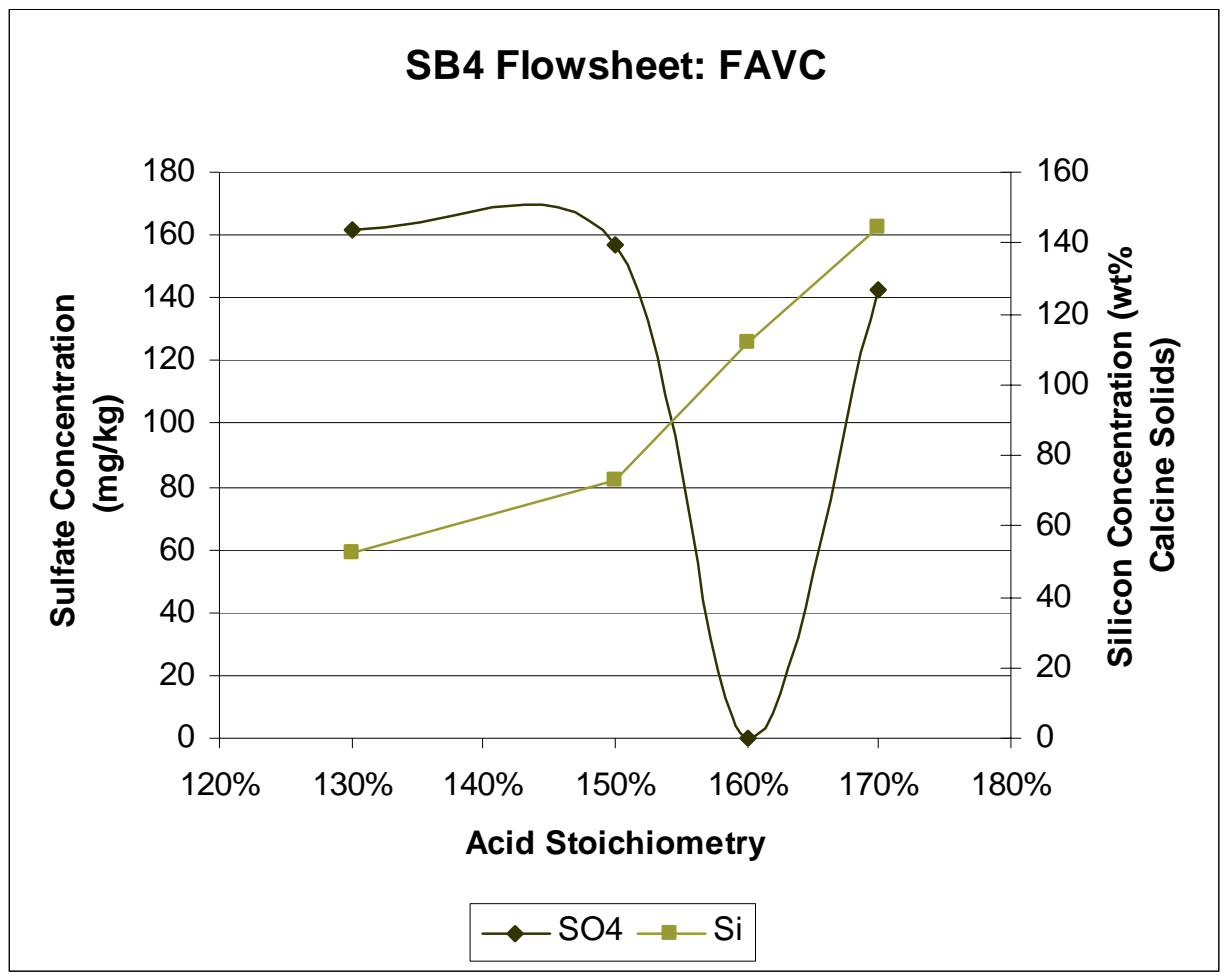

Figure B- 53. FAVC Sulfate and Silicon Concentration

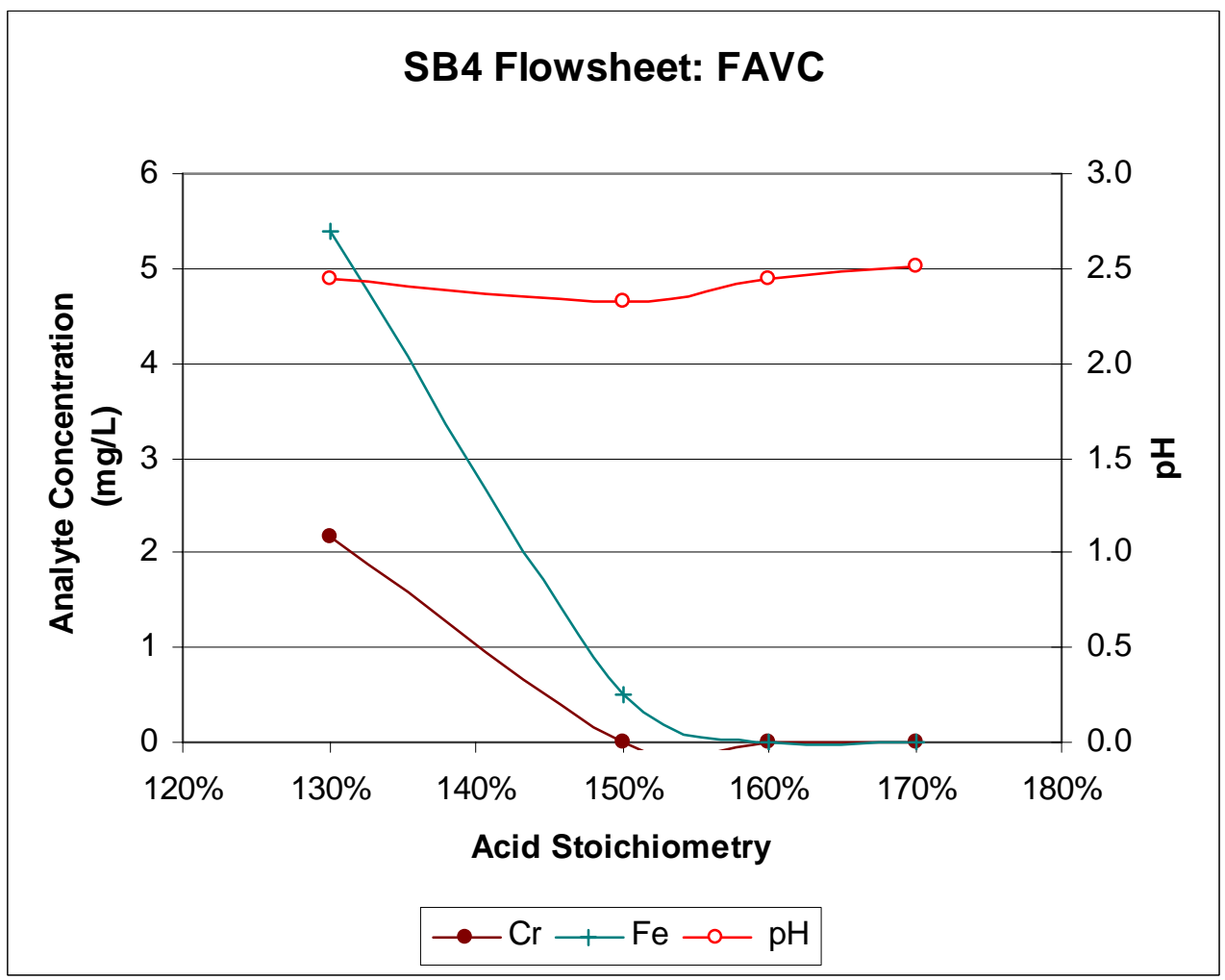

Figure B- 54. FAVC pH and Elementals 


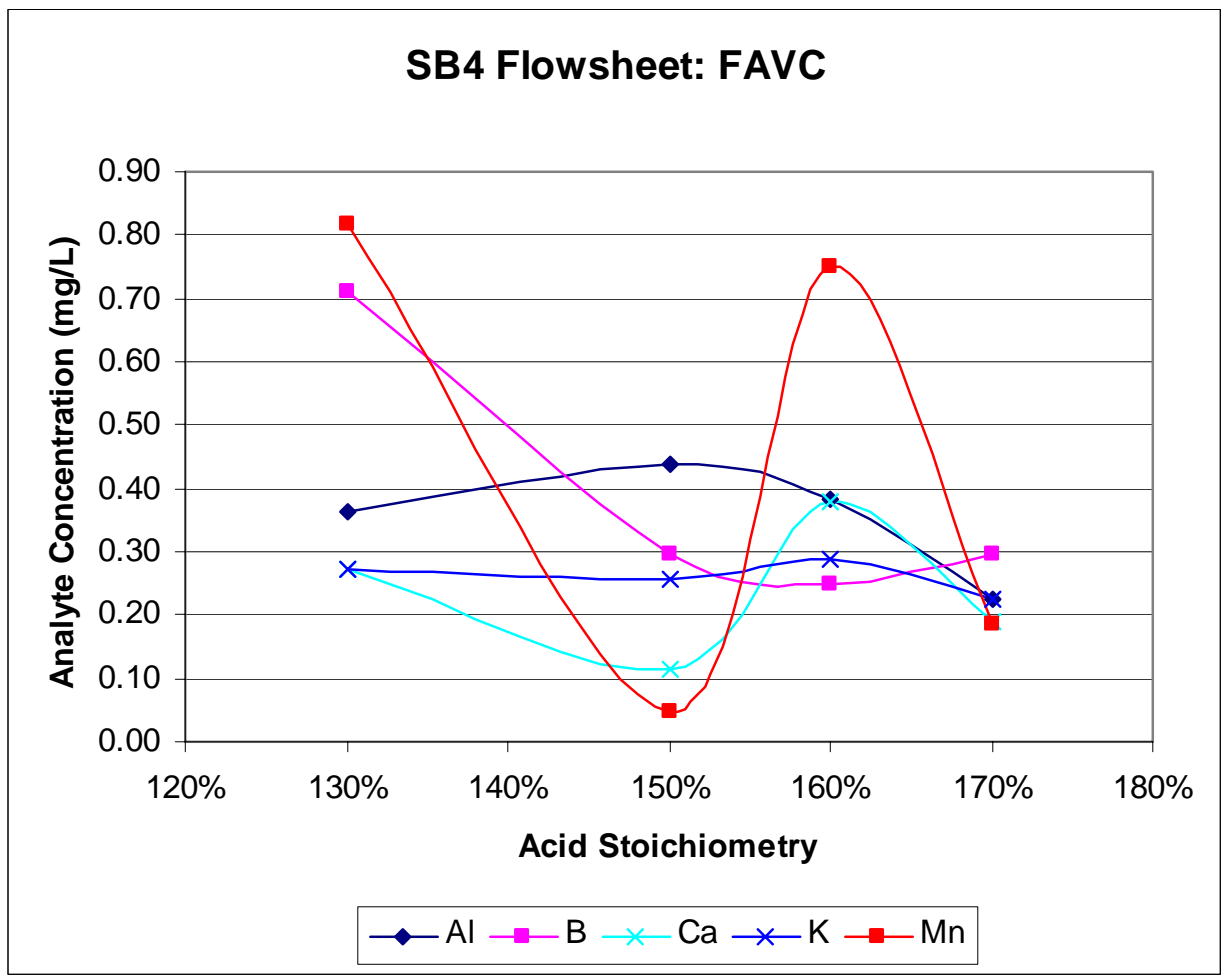

Figure B- 55. FAVC Elementals

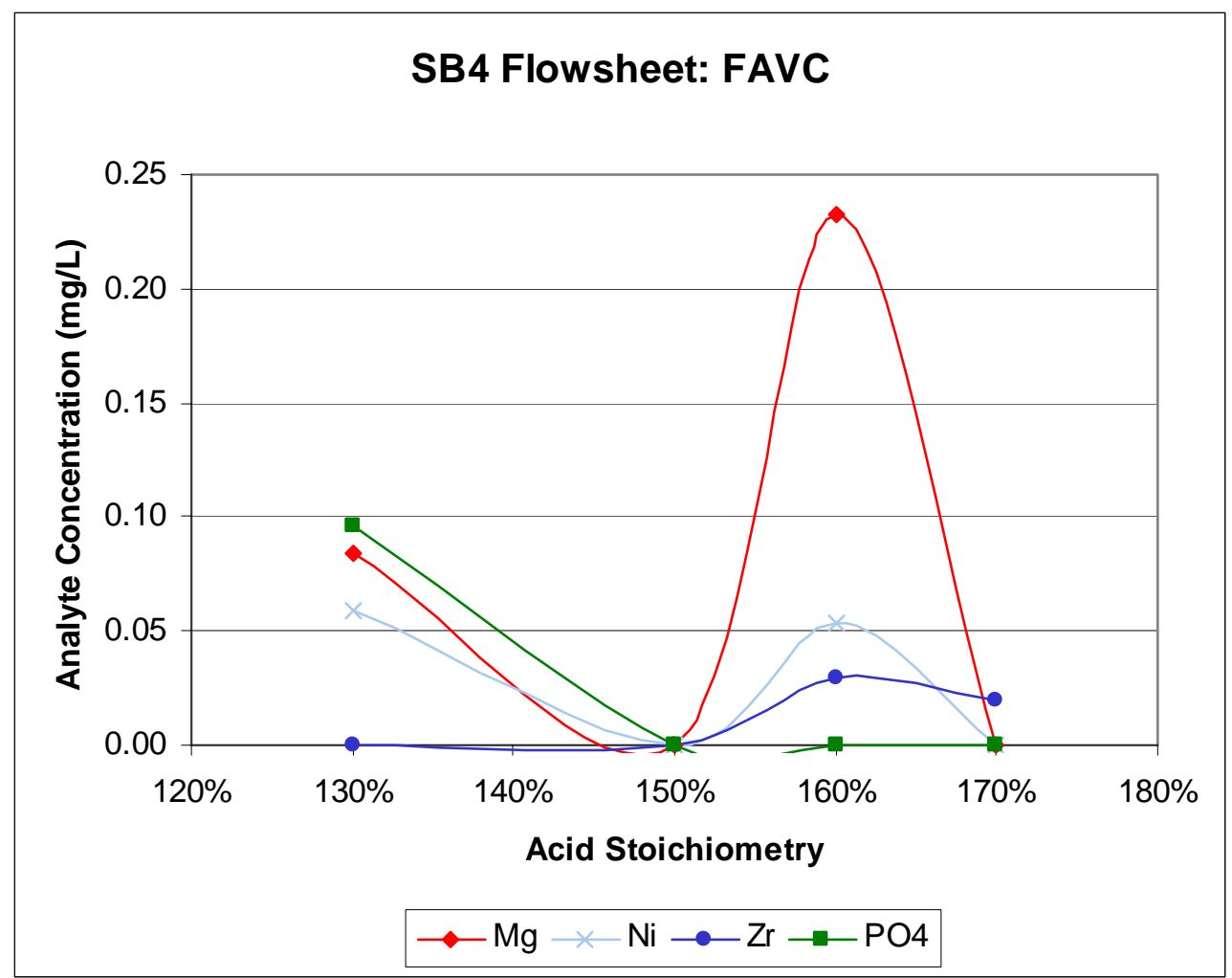

Figure B- 56. FAVC Trace Elementals 


\section{Appendix C. Offgas Composition Data}

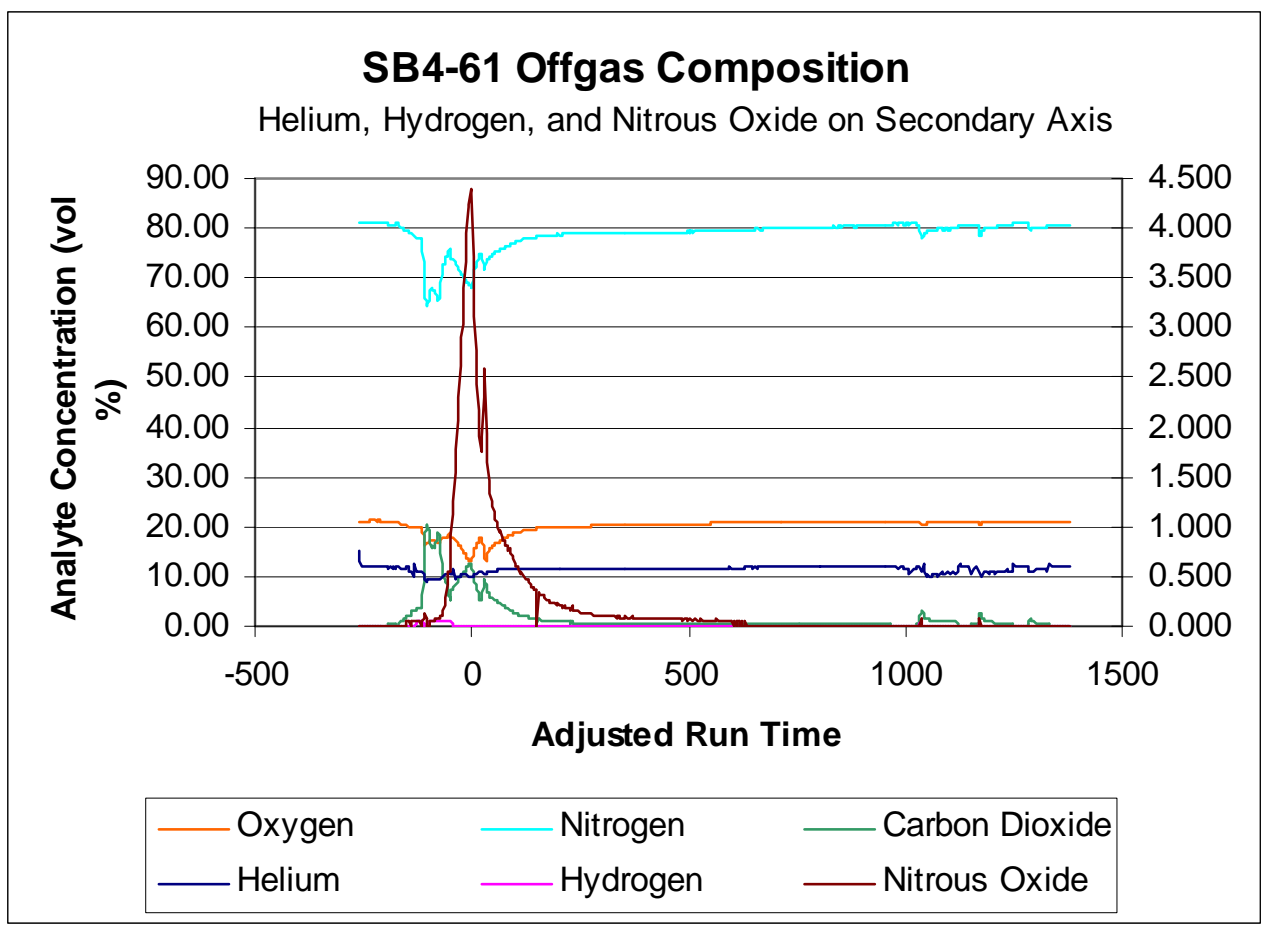

Figure C- 1. SB4-61 (130\% Acid) Offgas Data

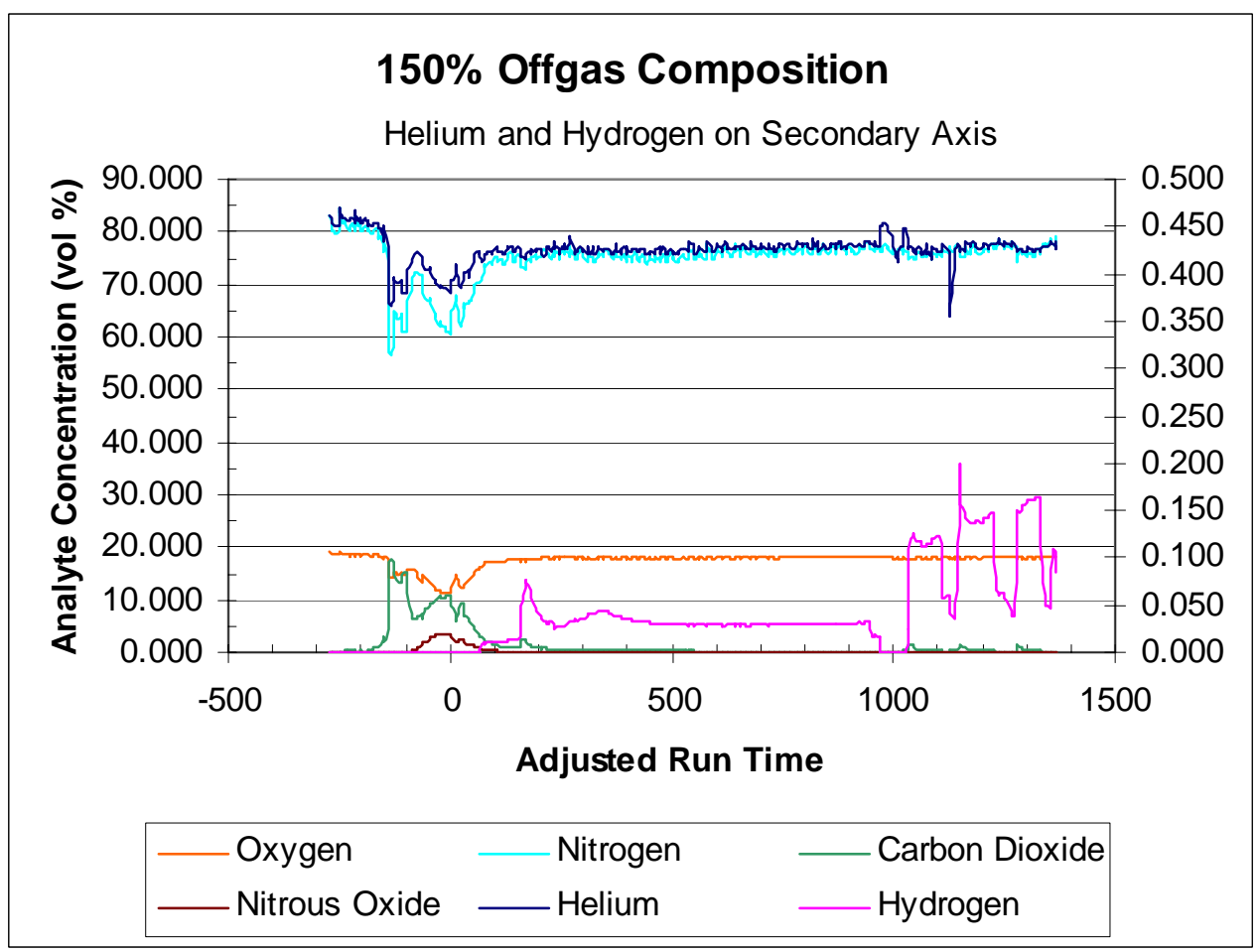

Figure C- 2. SB4-62 (150\% Acid) Offgas Data 


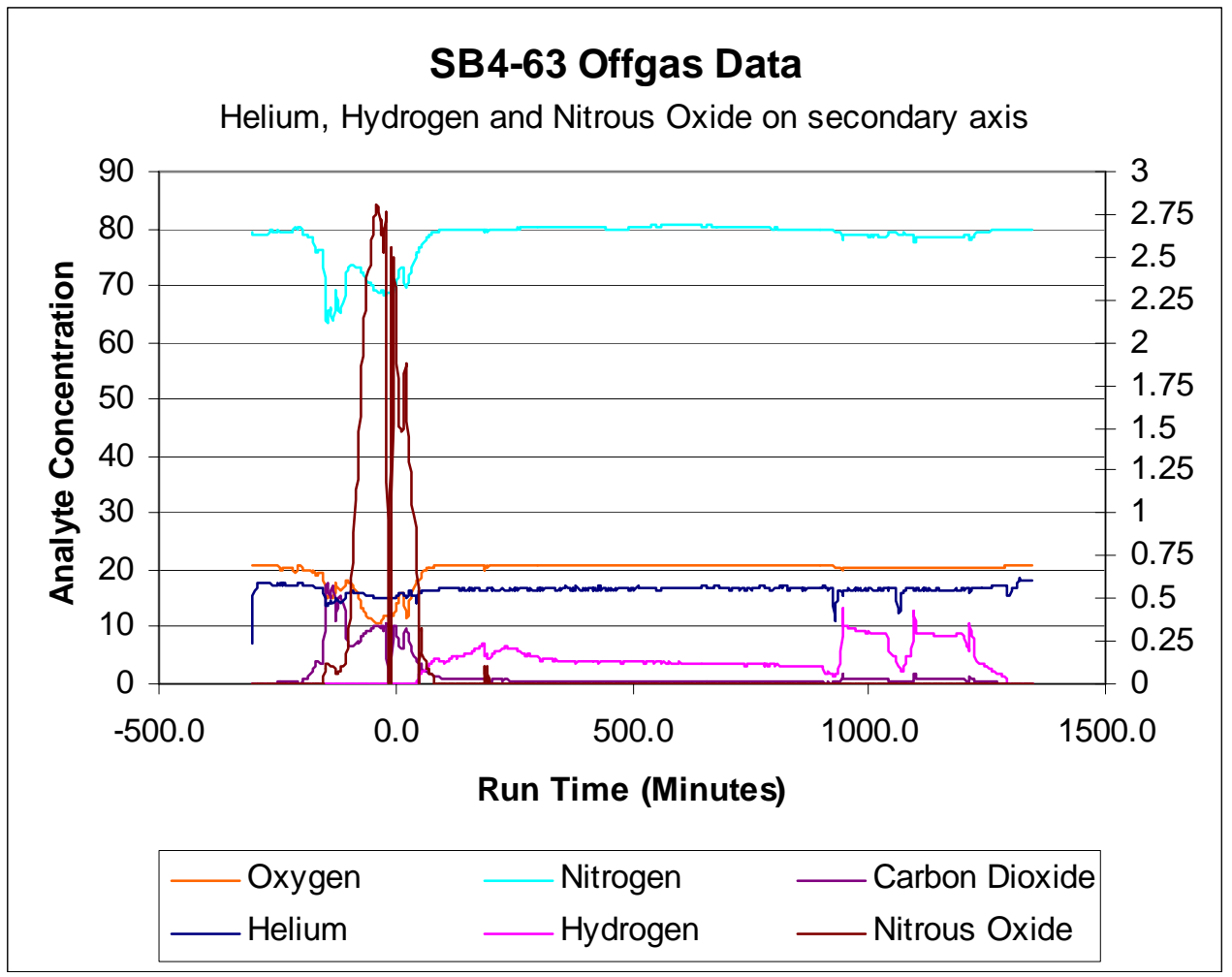

Figure C- 3. SB4-63 (160\% Acid) Offgas Data

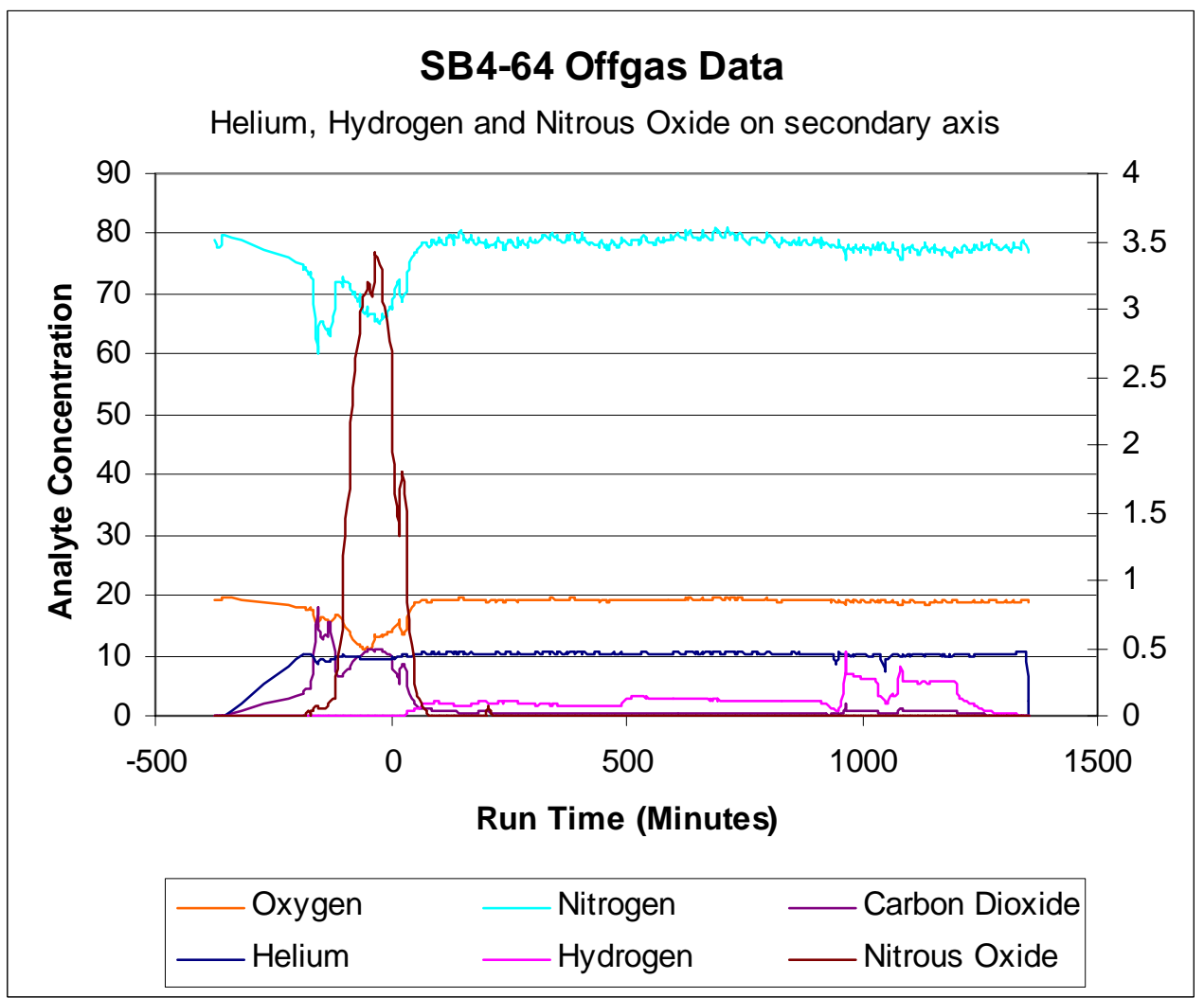

Figure C- 4. SB4-64 (170\% Acid) Offgas Data 
WSRC-STI-2006-00109

Revision 0

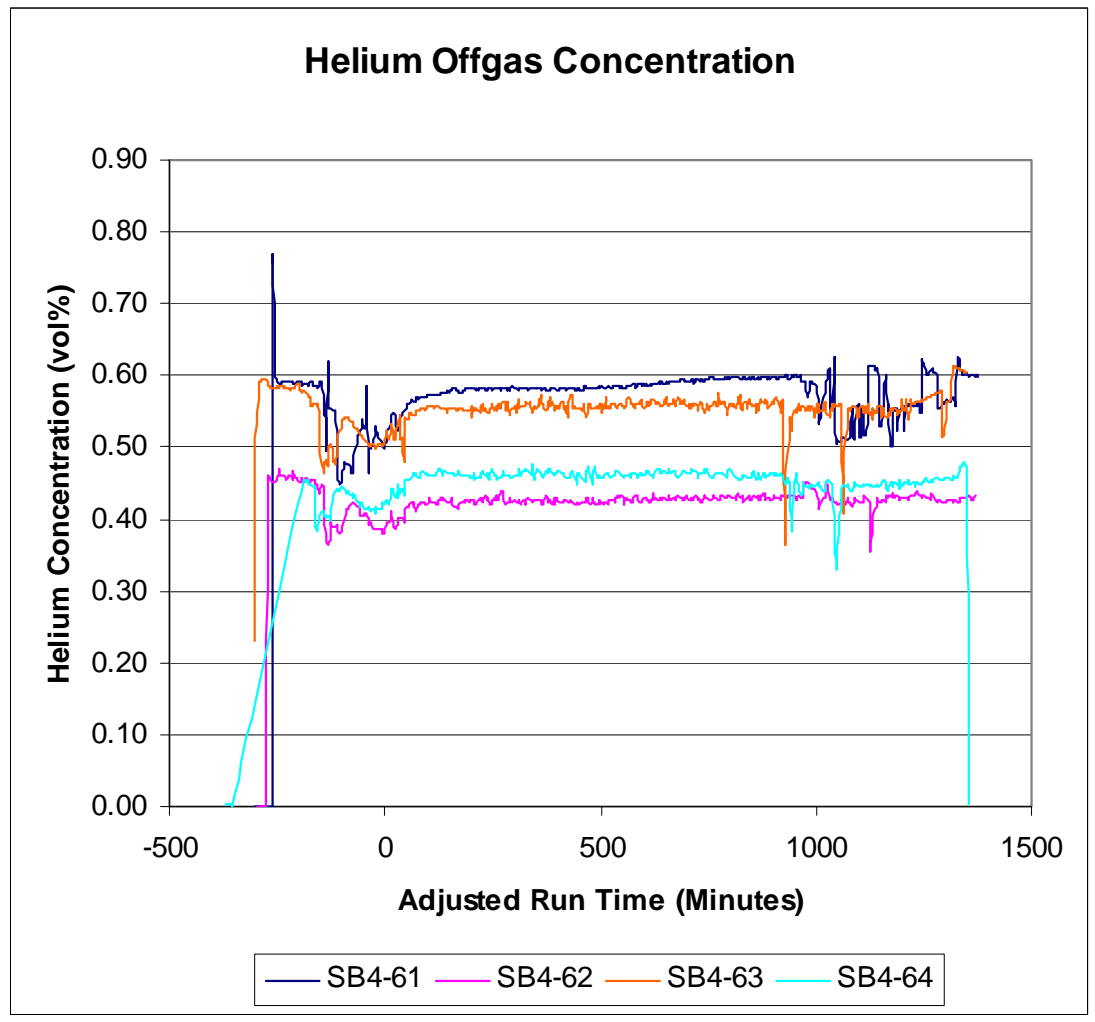

Figure C- 5. Helium Profiles

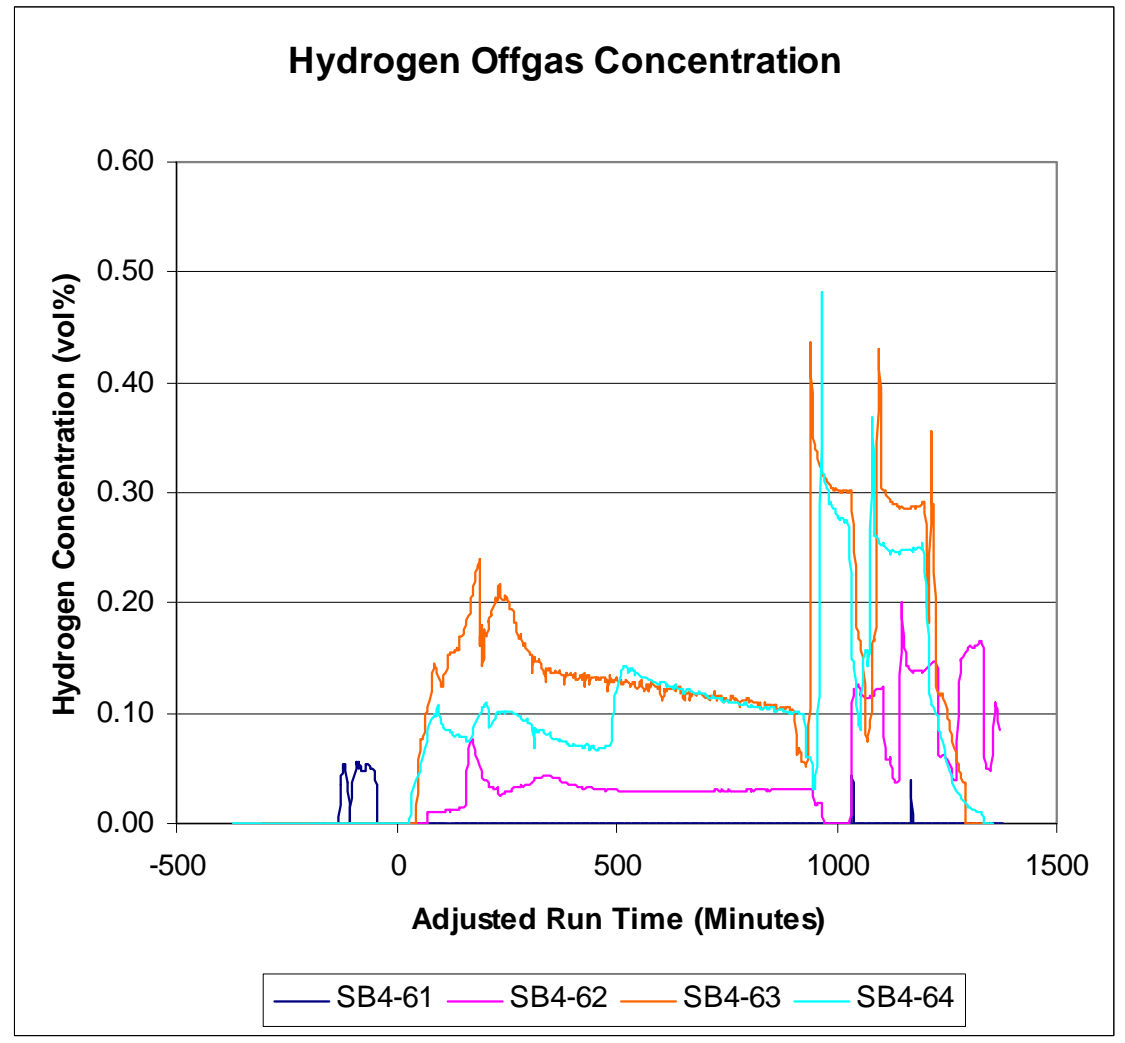

Figure C- 6. Hydrogen Profiles 
WSRC-STI-2006-00109

Revision 0

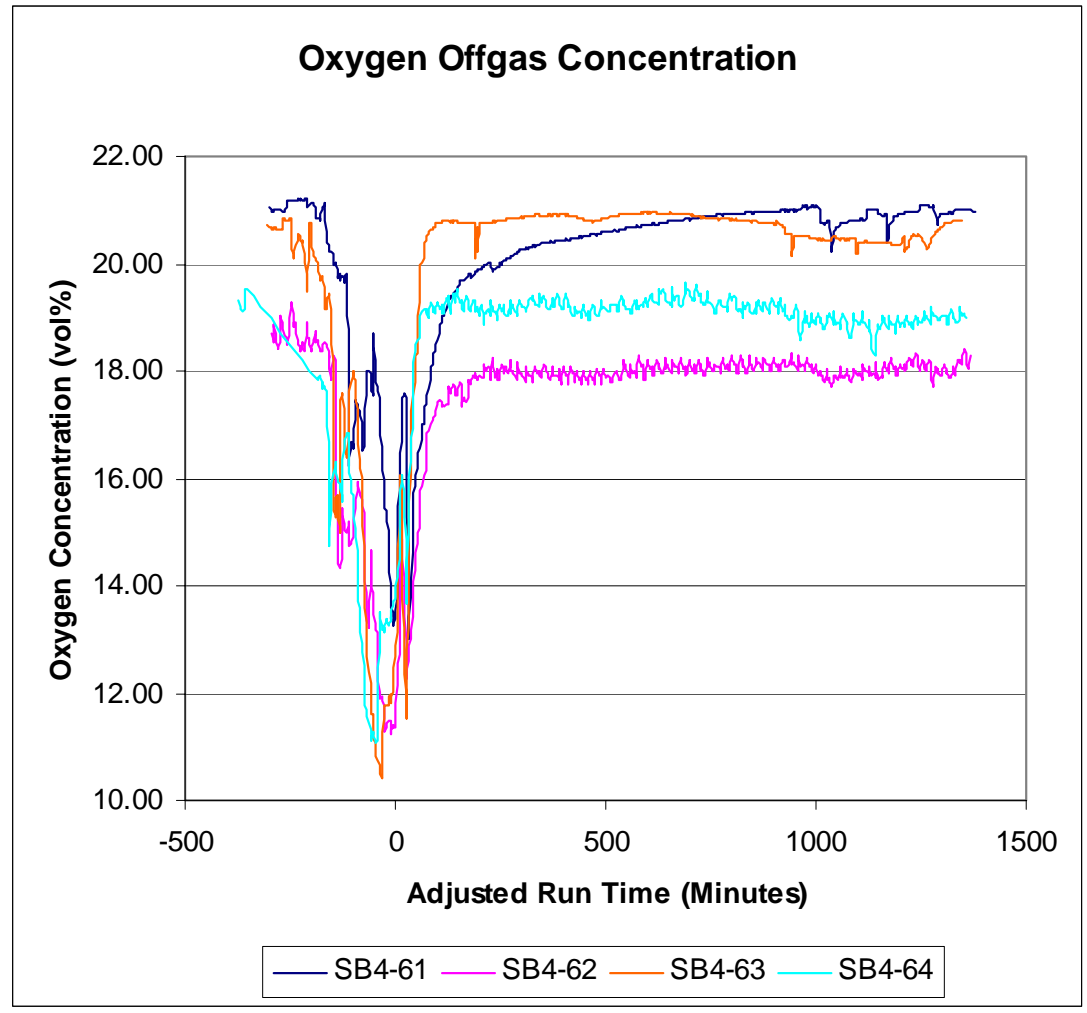

Figure C- 7. Oxygen Profiles

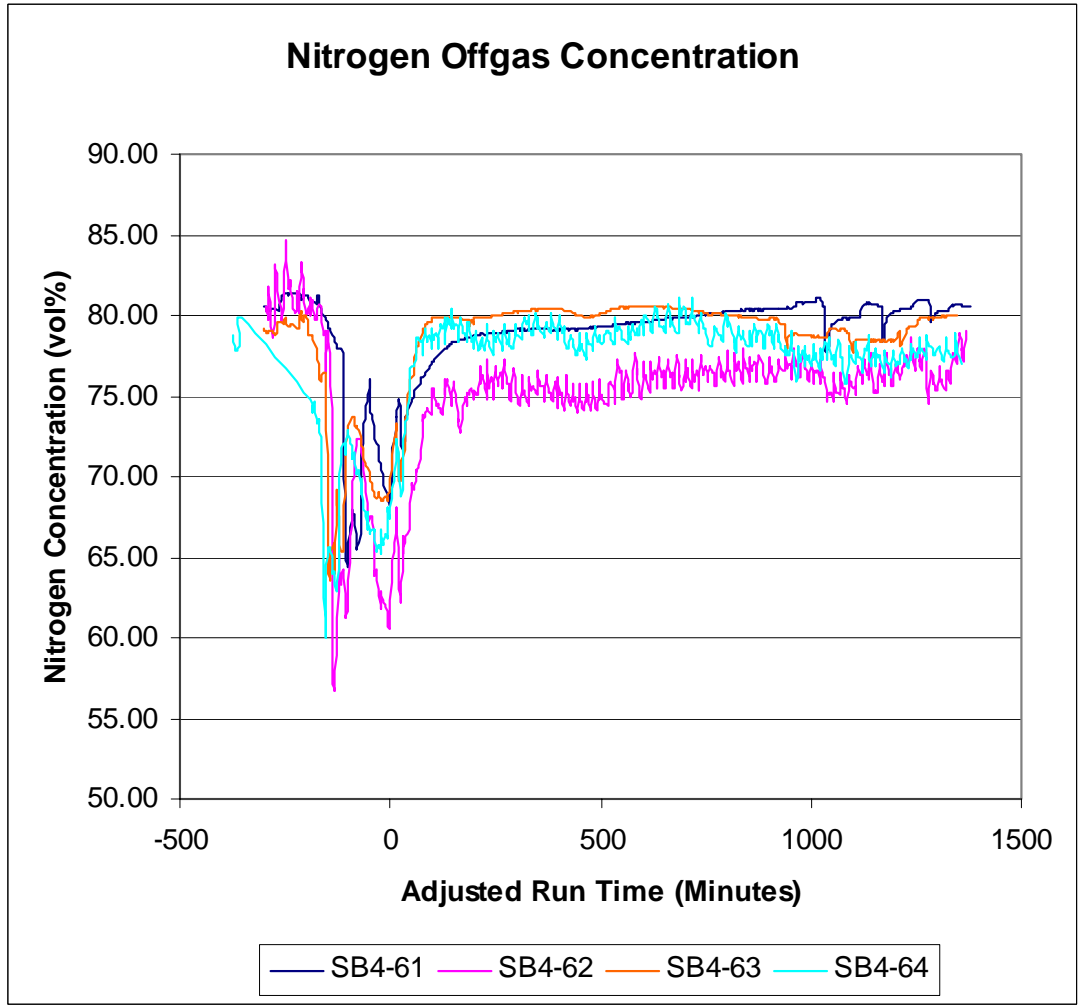

Figure C- 8. Nitrogen Profiles 


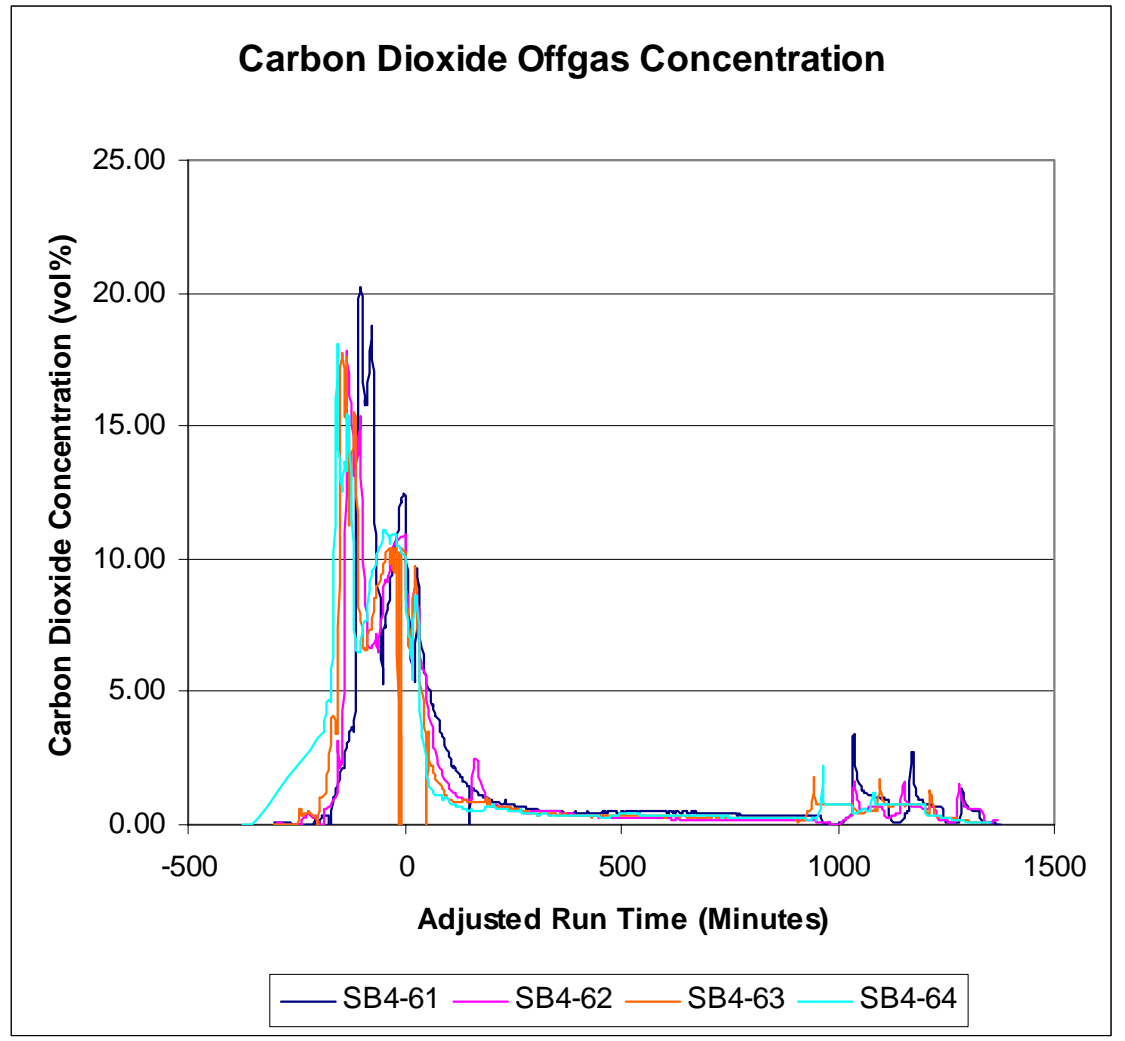

Figure C- 9. Carbon Dioxide Profiles

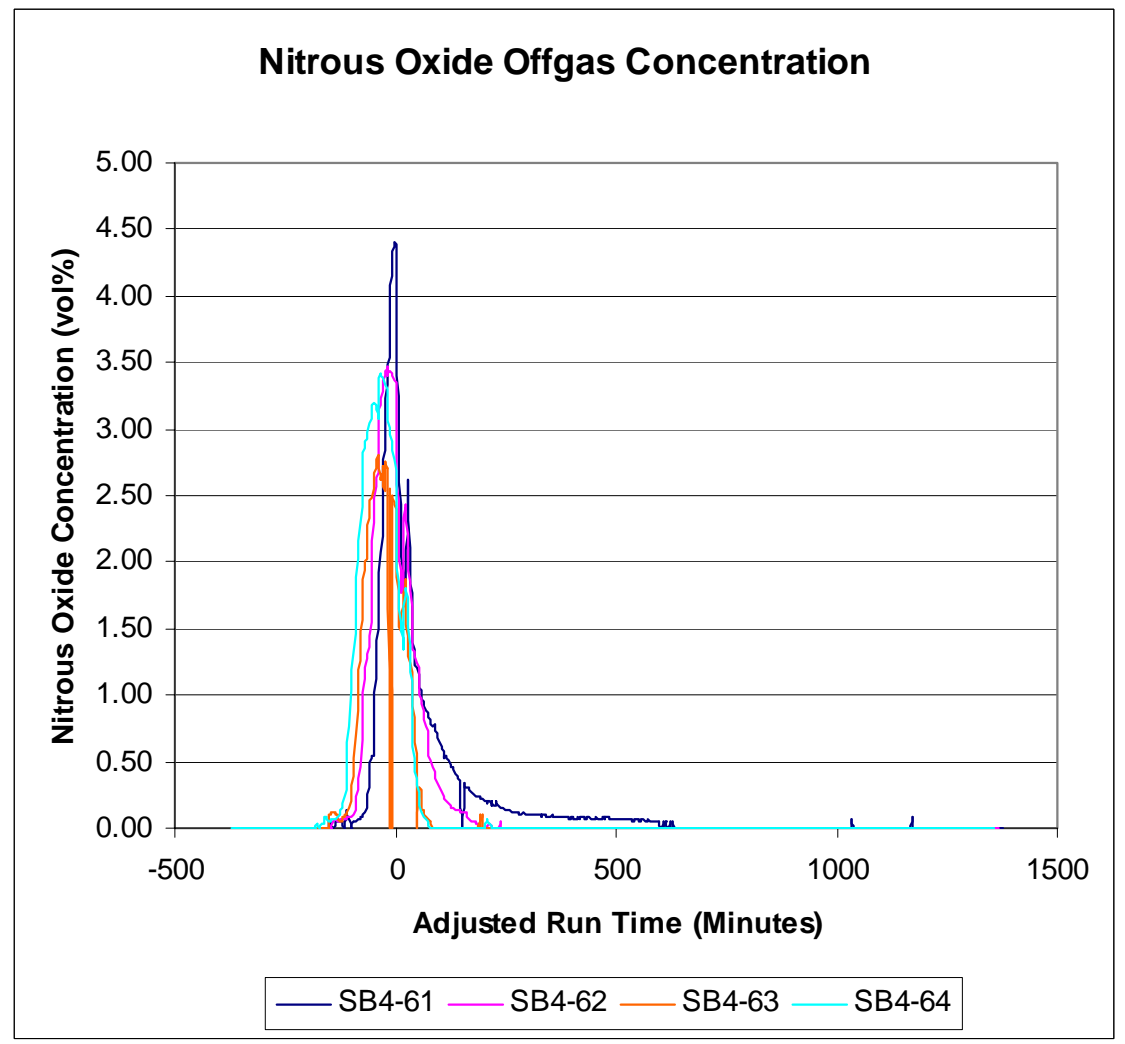

Figure C- 10. Nitrous Oxide Profiles 


\section{Appendix D. Rheological Results Charts and Flow Curves}

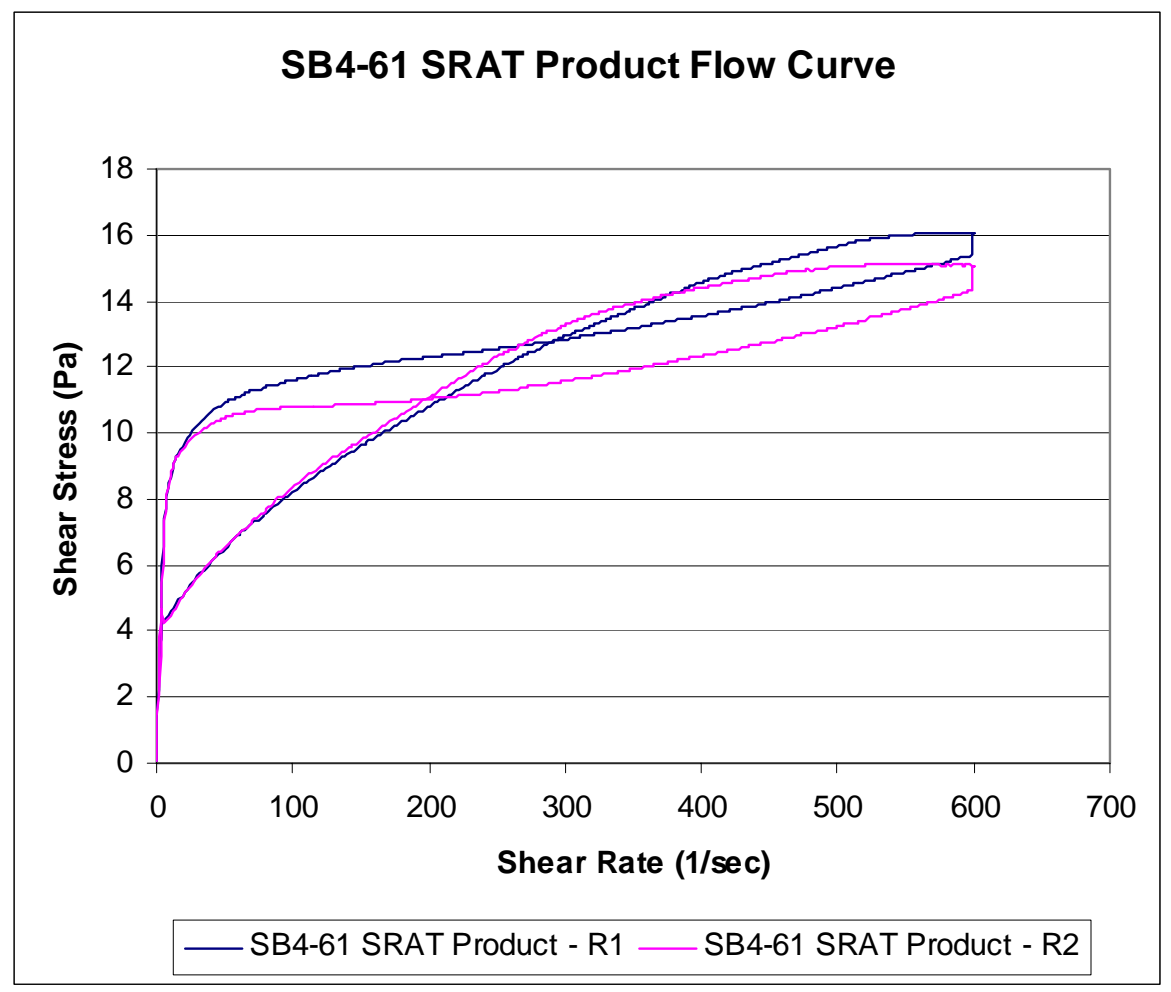

Figure D- 1. SB4-61 (130\% Acid) Flow Curves

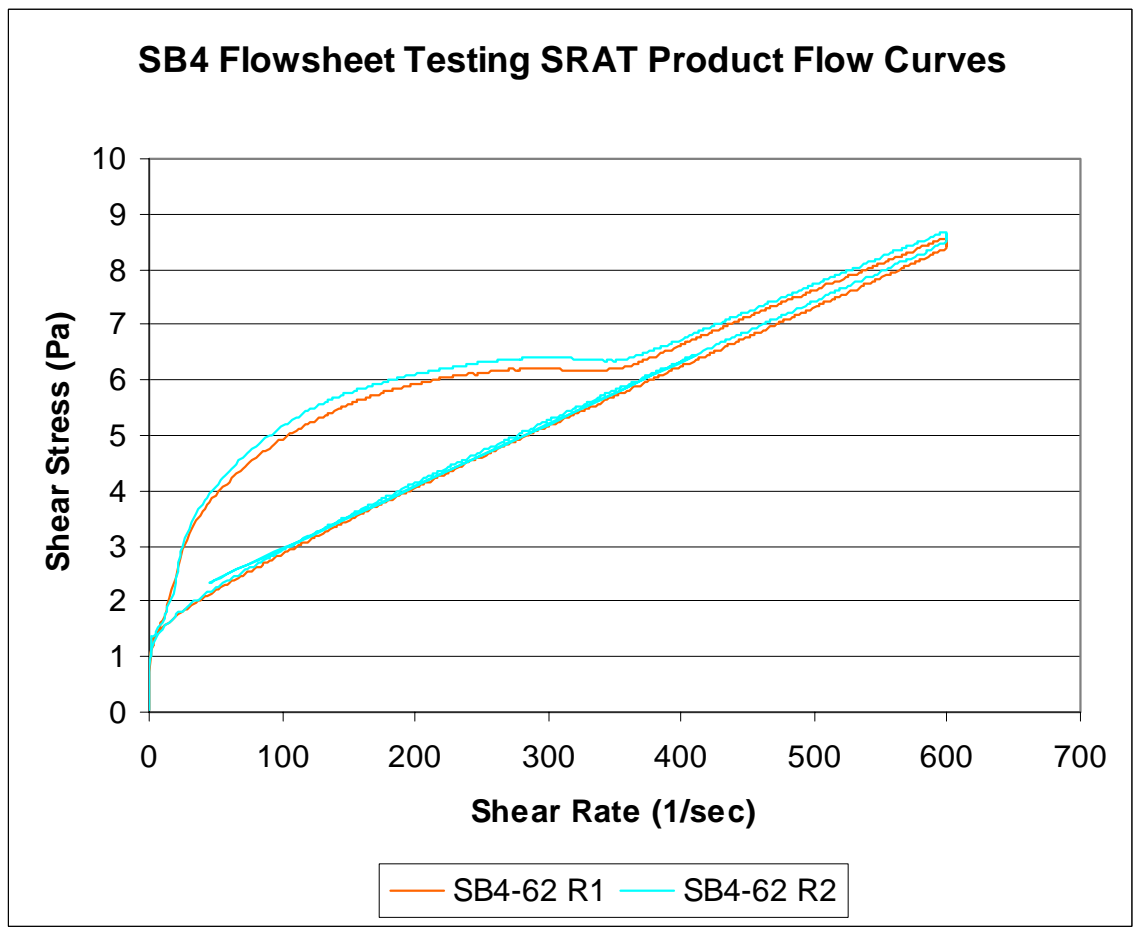

Figure D- 2. SB4-62 (150\% Acid) Flow Curves 


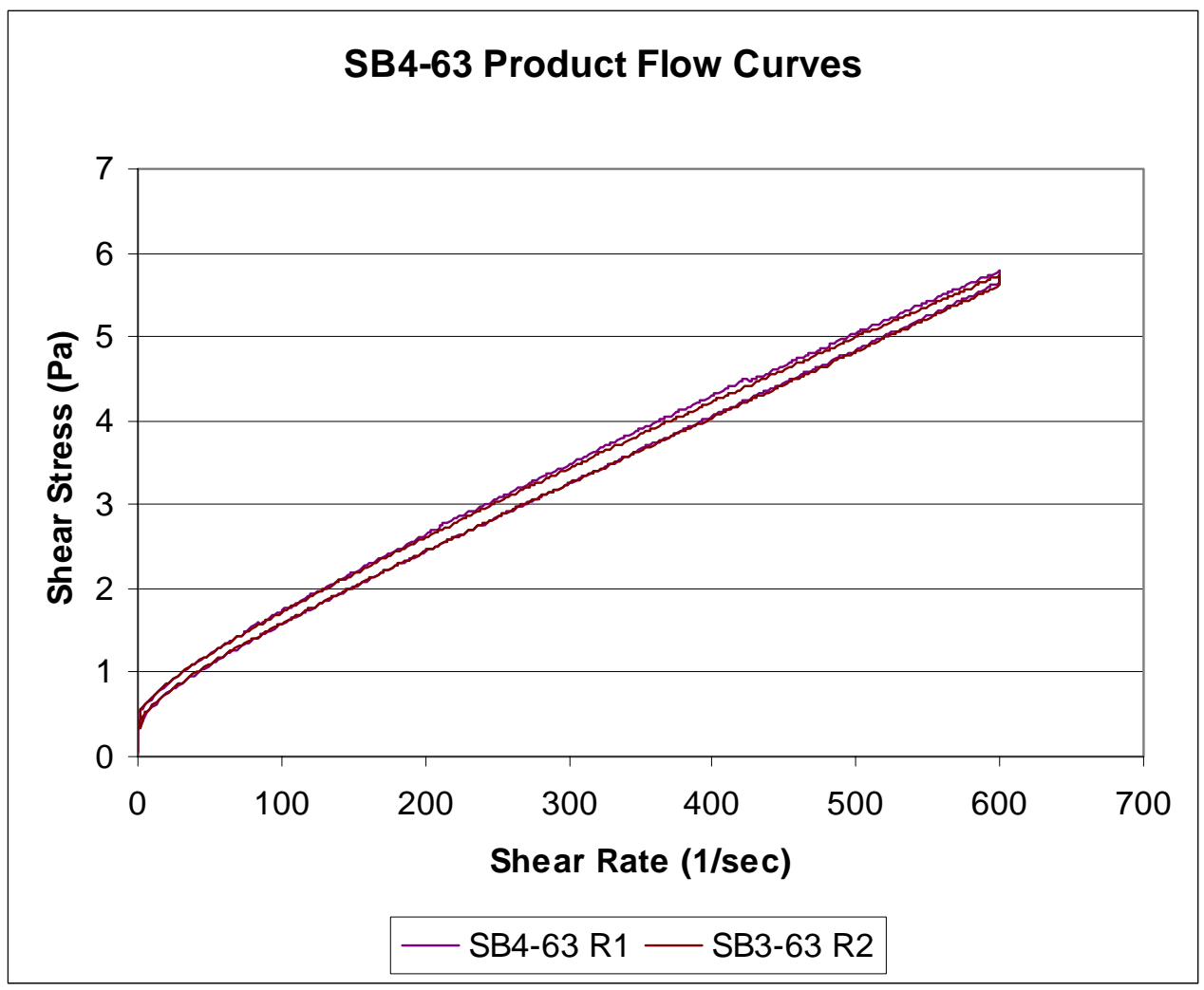

Figure D- 3. SB4-63 (160\% Acid) Flow Curves

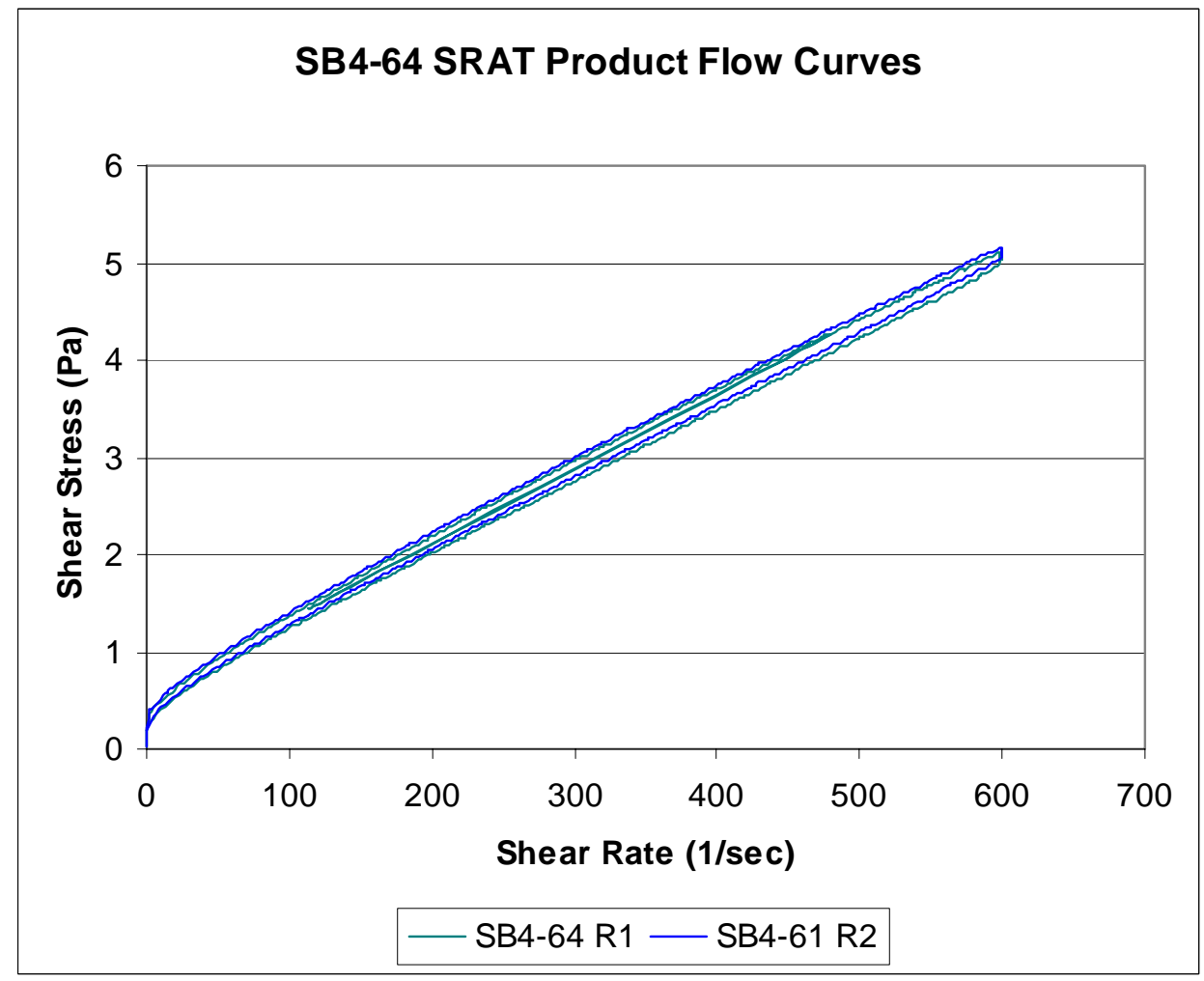

Figure D- 4. SB4-64 (170\% Acid) Flow Curves 


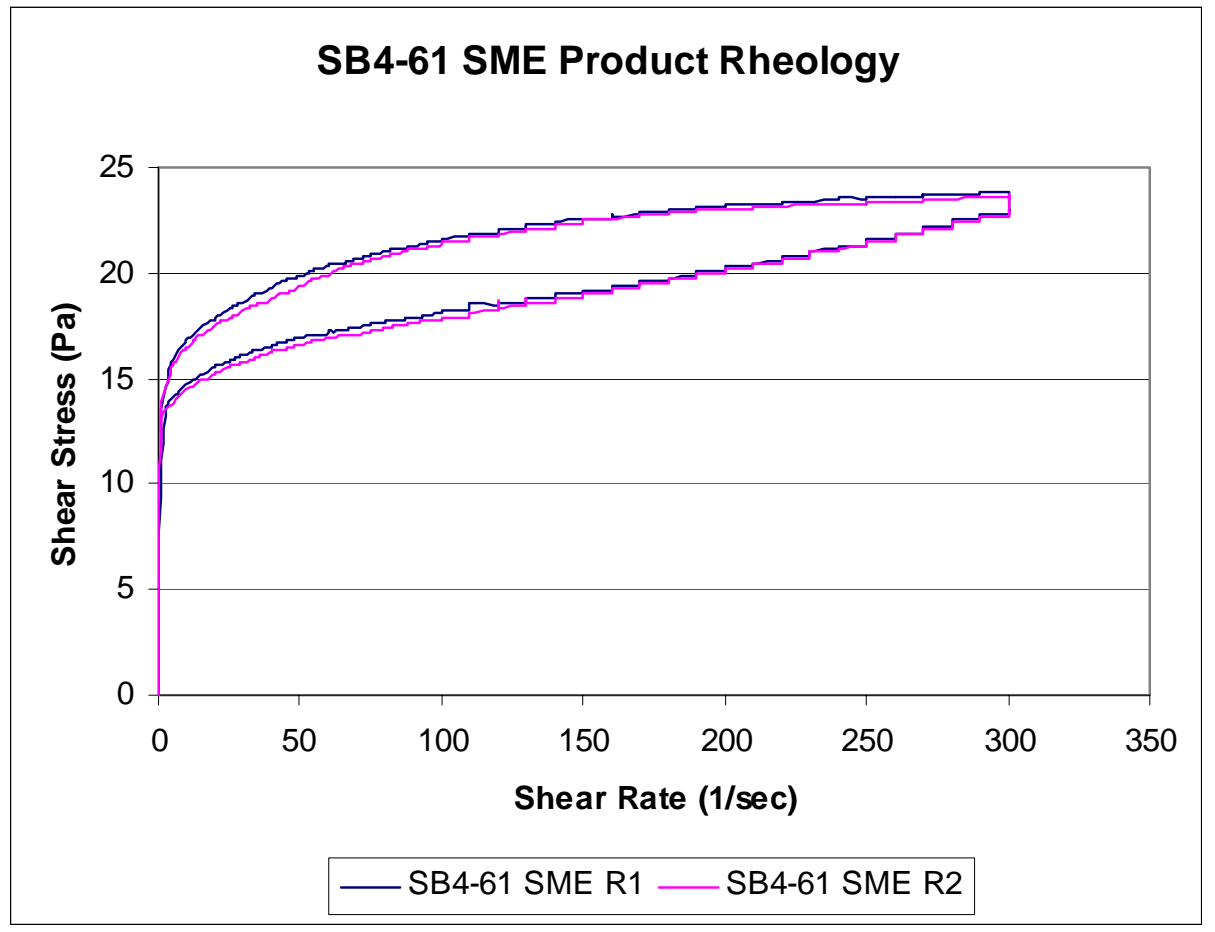

Figure D- 5. SB4-61 (130\% Acid) SME Product Flow Curves

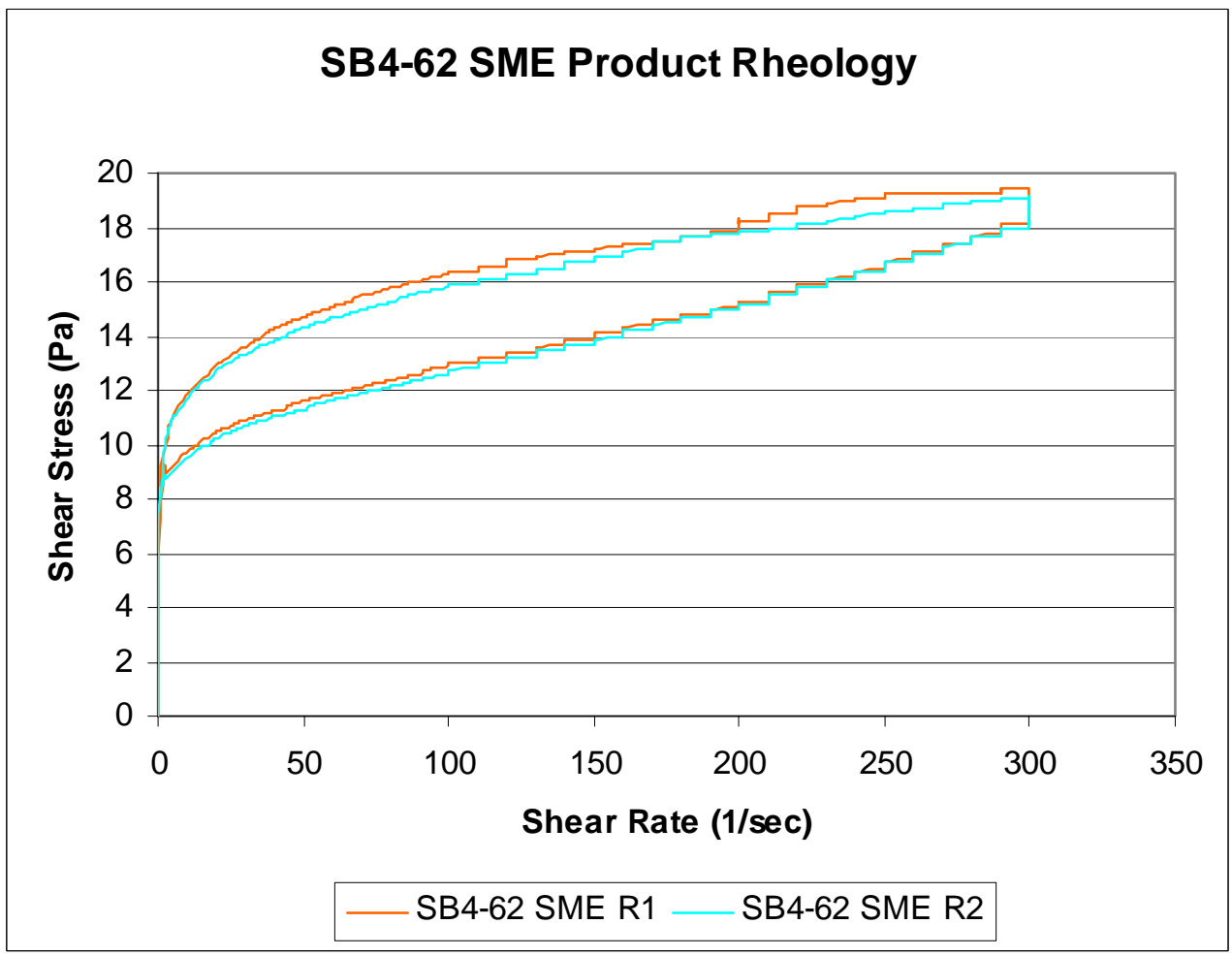

Figure D- 6. SB4-62 (150\% Acid) SME Product Flow Curves 


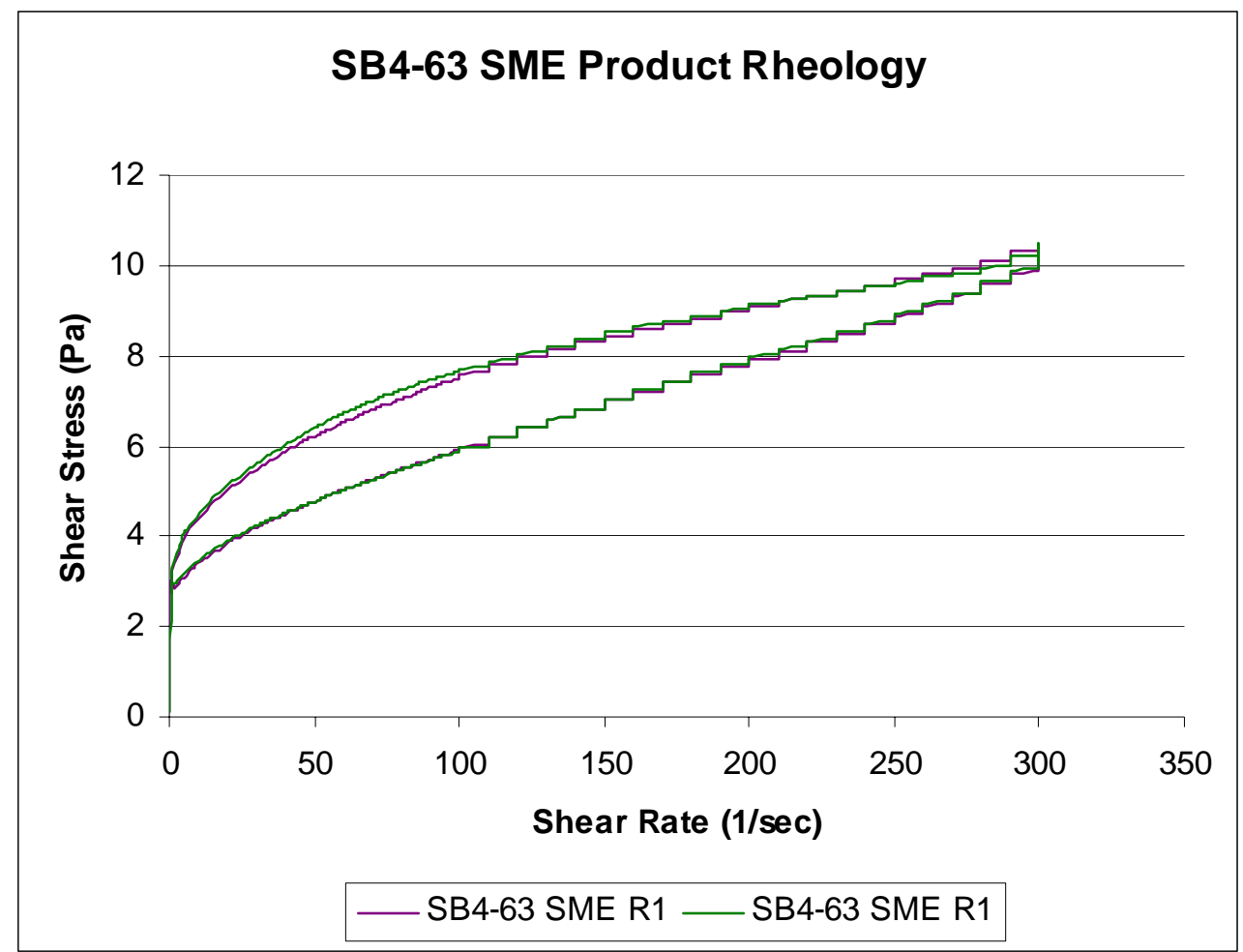

Figure D- 7. SB4-63 (160\% Acid) SME Product Flow Curves

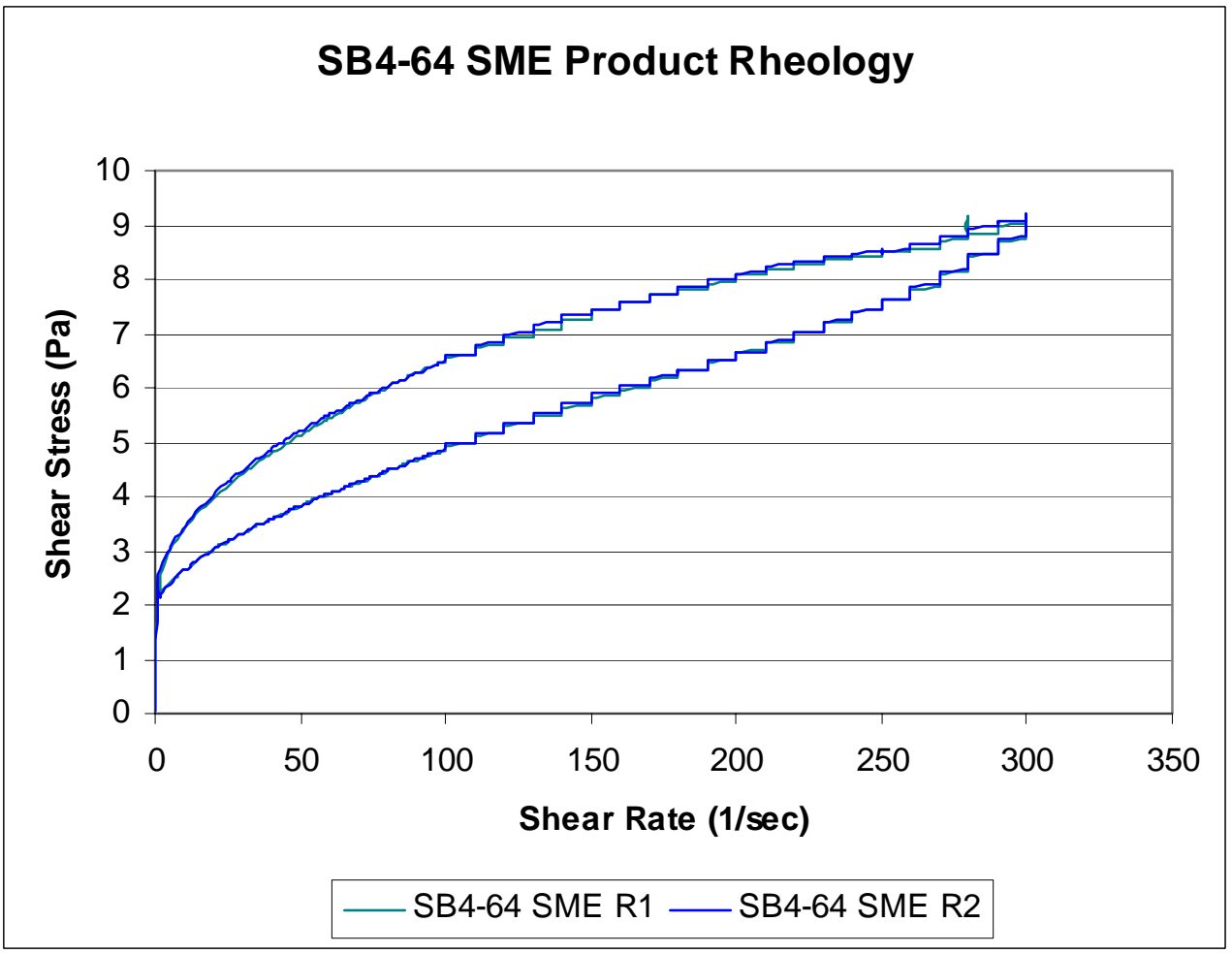

Figure D- 8. SB4-64 (170\% Acid) SME Product Flow Curves 


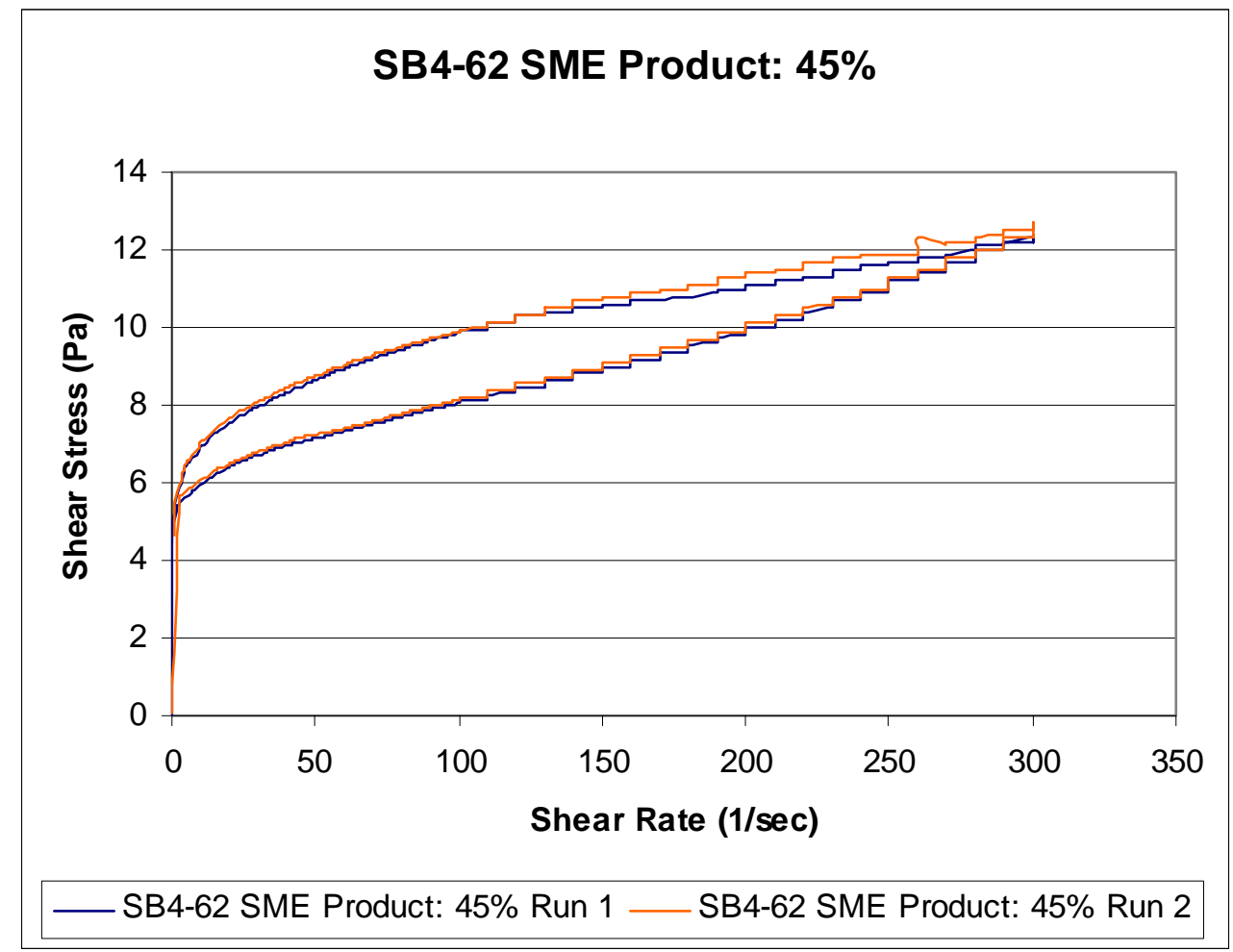

Figure D- 9. SB4-62 SME Product Adjusted to 45 wt\% Solids Flow Curves

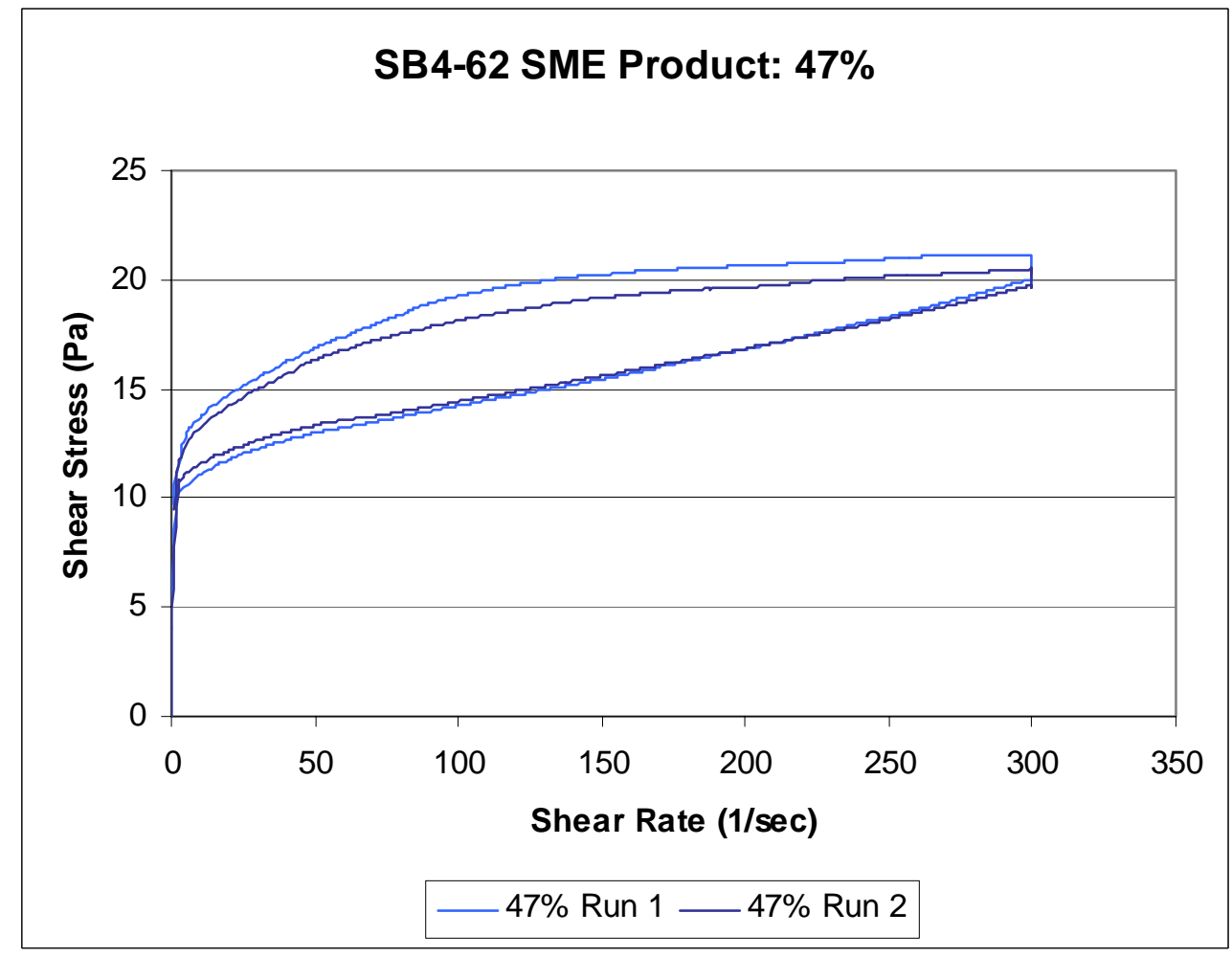

Figure D- 10. SB4-62 SME Product Flow Curves After Centrifuging 


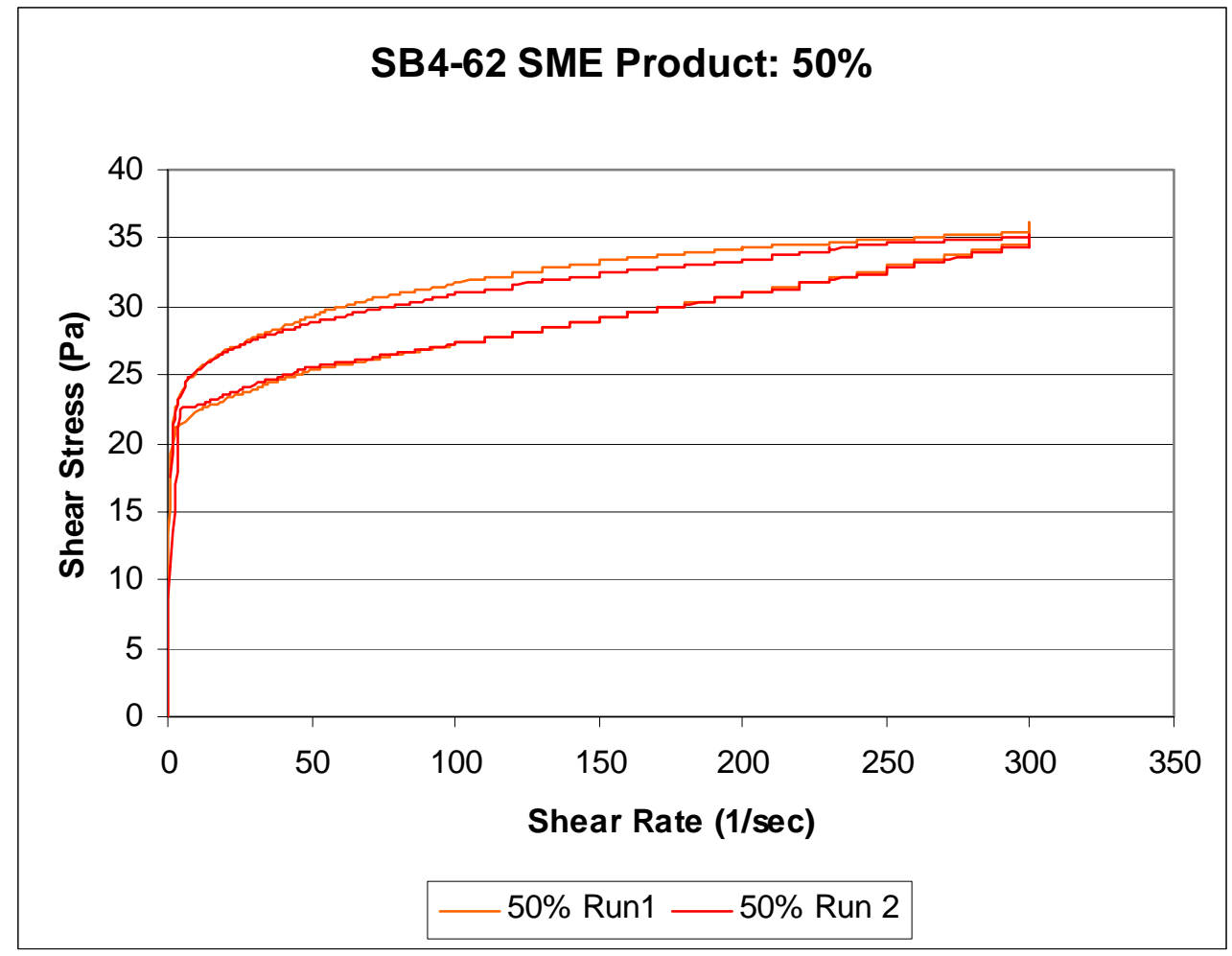

Figure D- 11. SB4-62 SME Product Flow Curves after Adjusting to 50 wt \% Solids

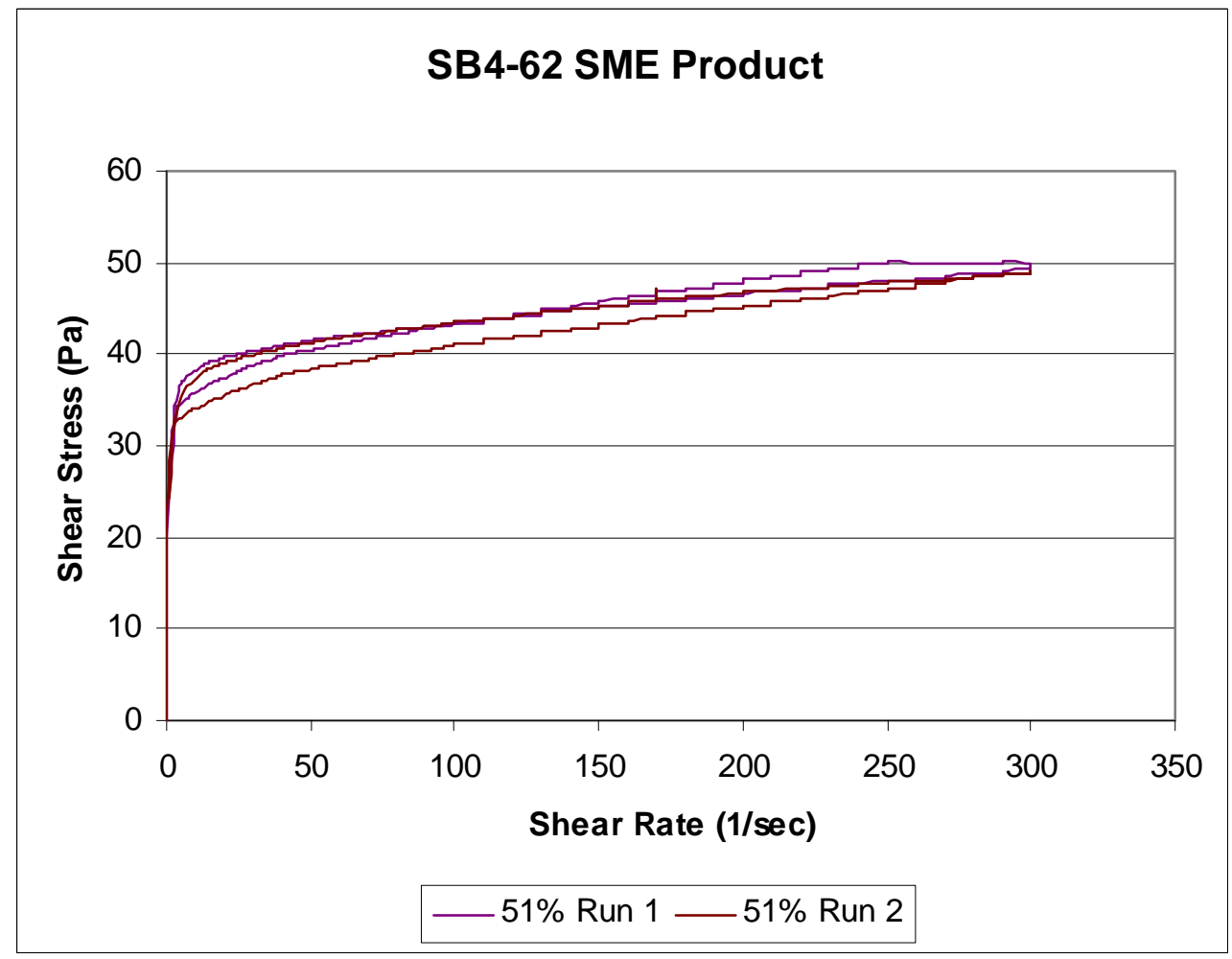

Figure D- 12. SB4-62 SME Product Flow Curves after Adjusting to 51 wt\% Solids 


\section{Distribution:}

J.E. Marra, SRNL

R.E. Edwards, SRNL

D.A. Crowley, 999-W

T.B. Calloway, 999-W

D.B. Burns, 786-1A

N.E. Bibler, SRNL

C.M. Jantzen, SRNL

J.R. Harbour, 773-42A

G.G. Wicks, SRNL

M. J. Barnes, 999-W

C.C. Herman, 773-42A

M.E. Smith, 999-W

M.E. Stone, 999-W

M.J. Barnes, 999-W

C.J. Bannochie, 773-42A

W.E. Daniel, 999-W

R.E. Eibling, 999-W

D.C. Koopman, 999-W

D.P Lambert, 999-W

J.M. Pareizs, SRNL

M.S. Miller, 704-S

J.E. Occhipinti, 704-S

R.M. Hoeppel, 704-27S

J.F. Iaukea, 704-30S

J.W. Ray, 704-S

B.A. Davis, 704-27S

M.A. Rios-Armstrong, 766-H

W.B. Van-Pelt, 704-S

H.B. Shah, 766-H

J.M. Gillam, 766-H

P.M. Patel, 704-27S 